
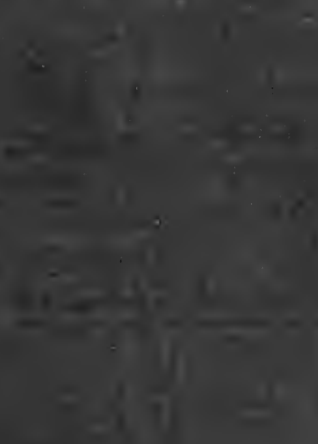





\section{LIBERTY DOCUMENTS}


Digitized by the Internet Archive in 2007 with funding from Microsoft Corporation 


\section{LIBERTY DOCUMENTS}

WITH CONTEMPORARY EXPOSITION

AND CRITICAL COMMENTS DRAWN FROM VARIOUS WRITERS

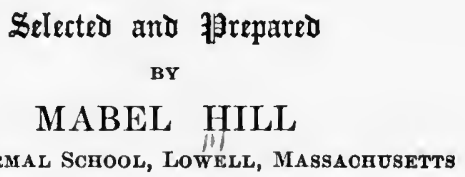

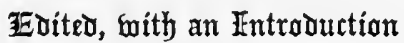

BY

ALBERT BUSHNELL HART, Ph.D.

Profegsor of History in Harvard University

NEW EDITION

L ONGMANS, GREEN, AND CO.

91 AND 93 FIFTH AVENUE, NEW YORK

LONDON, BOMBAY, AND CALCUTTA

1907 
Copyright, 1901, BY

LONGMANS, GREEN, AND CO.

All rights reserved.

First Edition, May, 1901

Reprinted, March, 1903; August, 1907

UNIVERSITY PRESS - JOHN WILSON AND SON - CAMBRIDGE, U.S.A. 


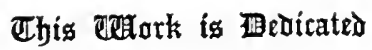

TO THE MEMORY OF

MY DEAR FATHER 



\section{P REFA CE}

THE design of this book is to direct students to the 1 evolution of constitutional government from the time of the declared policy of Henry I. towards his subjects to the present day. Its broader purpose is stated in detail in the Introduction, but a few brief words of explanation and acknowledgments of criticism and assistance give occasion for this Preface.

The following chapters are the result of informal lectures given before my classes at the State Normal School in Lowell, Massachusetts, where we have for several years followed a course of study in Constitutional History (as given in the Outlines in the Appendix of this volume). In preparing students for the profession of public school teaching, I have deemed it wise to impress them with the underlying principles of citizenship and government, and to prove to them that the love of liberty is a noble inheritance of the past.

In the special study of these written bulwarks of our freedom my aim has been to further the interest in original documents by comparing the details of the different articles, by discussing their bearing, by pointing out the development of constitutional history, and by noting the evolution of one document of liberty from the preceding one. The book makes no pretensions to exhaustive exposition, either of the documents discussed or of the critical material cited. It is meant as an aid to teacher and pupil whose time for historical research is limited, and it is but suggestive of the possibilities of further intensive study. 
The outline on Constitutional History has served its purpose with my own classes, and in the ninth grade of our grammar department of the Practice School it is used as the basis for more detailed work. The fact that a large majority of the pupils who are to be benefited by public instruction finish their technical education with the last year in the grammar schools makes it imperative that a course in American institutions and politics be presented which shall make intelligible to them the great race movement of which they are an integral part.

At the same time that I offer this work to my fellows in the profession, I beg to acknowledge my gratitude to those friends who have assisted me with aid, advice, and criticism. Professor Albert Bushnell Hart, of Harvard University, Cambridge, and Judge Samuel P. Hadley, of Lowell, Mass., have guided me materially in my research for contemporaneous and latter-day comments. Mr. Henry A. Clapp, of the Supreme Court of Massachusetts, has given most generously of his time in making translations from certain Latin texts. The Hon. James O. Lyford, naval officer of customs, Boston, Mass., has added to the varied suggestions and services of years by following the work of the outline with critical interest. I am indebted to the Librarians of the Harvard Library, Massachusetts State Library, and the Lowell City Library for their courteous liberality in the use of books.

I take this opportunity to thank the various authors and publishers of copyright works from which material has been drawn, for permission to reprint the passages desired. The full titles of these works, with publishers' names, are given in Appendix $\mathrm{D}$ at the end of this volume.

MABEL HILL.

Lowell. Mass., November, 1900. 


\section{INTRODUCTION}

THAT history is based on sources no longer needs asser1 tion; that the public state papers of the nation are among the most important sources for an understanding of the true spirit of past times has been a familiar truth since Dr. Stnbbs put forth his immortal volume of Select Charters; no careful student and no thoughtful teacher any longer attempts to investigate or to present history without reading and thinking about the constitutional sources. Dr. Stubbs, however, was one of the men most aware that a document does not explain itself; it was his practice in his classes to expound and criticise his own charters. As the knowledge of, and publication of, materials has widened, choice and a suggestive arrangement have become more and more important in making up useful collections; and there is now a great mass of intelligent discussion by historians and publicists, which may be drawn upon by those who have been unable to sit at the feet of the masters. It is an encouragement to those most interested in history that there seems a demand for reprints of properly selected sources, and especially of constitutional documents illustrated by some reference to contemporary writers, set forth by adequate comment, and so arranged as to bring out the development of a nation's constitutional progress.

Miss Hill, in her Liberty Documents, has undertaken to provide for what is believed to be an interest in the foundations of English and American free gorernment: at the same time she has endeavoured to avoid some of the obvious diffeulties in 
dealing with official and sometimes technical documents, by supplementing them with the light and life of discussion. The most approved method of historical teaching for schools of various grades, seems to be a text-book, backed up by reading both in the sources and in secondary books. Miss Hill has in this book brought about an ingenious and promising combination of the two sorts of historical.material; and she has further divided the authors whom she uses, according as they wrote at or near the date of the documents, or as they came afterward, and could use the learning that had meantime accumulated. Out of the immense number of interesting and important documents in English and American constitutional history, Miss Hill has chosen twenty-four documents, or groups of documents, which include the great monuments of Anglo-Saxon liberty, and at the same time are sufficiently representative of the mass of omitted papers. Each of these documents she has prefaced with appropriate "Suggestions" which include some statement of the historical conditions under which the document first saw the light, and in a few words shows the relation of each piece with other materials of the same kind. Then follows in each case the "text" of the document. The earlier pieces, such as Magna Charta and the Confirmatio Chartarum, were written in Latin; and therefore translations have been reprinted, or made expressly for this volume. The English documents of the seventeenth century were of course first written with the spelling, capitalization, and abbreviations usual at that time, and they have been transliterated by substituting the ordinary form for the long $s$, and reducing the capitalization and spelling to modern usage. The documents of the eighteenth and nineteenth centuries are in general reproduced verbatim. In all cases an authentic text has been examined and compared, and omissions are indicated. As an example of the technical phraseology of English statutes, and in order to put at the convenience of the schools the full text, 
of a document very hard to find in full, the Habeas Corpus Act of 1679 has been reprinted exactly as it stands, as an Appendix.

After the text of each document follows the next feature of the book, the "Contemporary Exposition," especially helpful because it shows why our ancestors felt that the great documents were essential to them and their posterity. The range of writers on English constitutional matters is ample; and Miss Hill has been successful in finding plenty of appropriate and striking criticisms. An example, and one of the most quaint things in the book is Bishop Burnet's humorous account of the parliamentary trick by which the Habeas Corpus Act came to be passed. In the American part of the work good contemporary comment abounds, and most of the famous American statesmen have been drawn upon, together with pamphleteers and public speakers.

The fourth part of each chapter is the "Critical Comment," made up of approved criticisms from a considerable number of authors; here the best brief histories of England and the United States have been drawn upon, together with such special authorities on constitutional development as Stubbs, Hallam, Pollock and Maitland, Gneist, Boutmy, Blackstone, Borgeaud, Dicey, Curtis, Story, Bryce, Cooley, and Dunning. It is to be understood that these extracts are not chosen to defend a thesis or to favour any bias in Miss Hill's mind. She has taken pains to draw from people of different and even of opposing views; and to quote from authors who seem to sum up the results of the discussions and investigations of a succession of publicists.

The purpose of this work, then, is in brief to place some of the most important memorials of listory of the Anglo-Saxon race in a suitable and illuminating setting; the document itself in a carefully verified text; the opinions of contemporaries who are interested and competent; later comment of scientific 
writers, who have studied the documents through the perspective of human progress.

For such a work Miss Hill has long felt the need; in her own work as a teacher in secondary and normal schools, she has found it possible to interest young people in such studies of the institutional side of English and American history; the book therefore represents what may be, and actually is, taught in schools. None of these documents are beyond the grasp of a properly directed child of fourteen, and the book is easy to handle because it contains the materials for its own discussion.

A glance at the Table of Contents will show the principles which have been kept in mind in putting the book together. First of all will be noticed the long reach of the selections : the first document was written in 1101 ; the last report of a speech is still hardly dry from the press. The results of eight centuries of constitutional effort are stated or suggested in this volume.

The book is an example also of the modern discovery that history is as continuous as geology; that so-called political revolutions are, like earthquakes and volcanic outbreaks, the sudden yielding to strains which have been growing more intense from year to year and age to age, till there is no longer a power of resistance. The book brings into clear and sharp relief the great truth that English and American constitutional history has run practically one course. The first ten chapters show the growth of English personal liberty down to the beginning of the eighteenth century; Chapters XI. to XIV. exemplify the change in the eighteenth century and the Revolution, from an English to an American form of statement of the principles of freedom. From Chapter XV. to the end, we find a record of the establishment and the growth of written constitutional guarantees in America. These three periods are really not separable from each other: for English institutions run into Colonial charters, and thence into State constitutions, 
and the State constitutions were really a part of the general system of which the Federal constitution became a corresponding part. From the beginning to the end, there has been a kind of rolling-up of guarantees for the liberty of the individual, so that Magna Charta, the Petition of Right, and the Bill of Rights, the Declaration of the Stamp Act Congress, the Declaration of Independence, Washington's Farewell Address, and the Proclamation of Emancipation are all a part of that conception of human rights which is the proudest outcome of American experience.

The choice of documents must, of course, depend to some degree upon the personal interest and judgment of the person who may prepare such a work, although certain papers can no more be omitted from the set of Liberty Documents than the letter " $\mathrm{e}$ " can be left out of the alphabet. A part of the intellectual outfit of all properly trained American children is Henry First's Charter, Magna Charta, Confirmatio Chartarum, Habeas Corpus, Bill of Rights and Act of Settlement, Declaration of the Stamp Act Congress, Virginia Bill of Rights, Declaration of Independence, Articles of Confederation, Northwest Ordinance, Federal Constitution, Waskington's Farewell Address, Dred Scott Decision, Proclamation of Emancipation, and the Reconstruction Amendments.

All these are to be found within the following pages, and also some selections less common but not less truly representative. In Chapter III. will be found two very racy letters written by Thomas Cromwell, which bring out a stalwart conception of how to deal with a parliament. In Chapter V. is inserted a very significant extract from a statute of 1429 , which illustrates the steady though slow development of the protections of liberty, and also shows the usual forms of royal statutes six centuries ago. In Chapter VII. have been printed two of the unsuccessful constitutions of the English Commonwealth; they deserve attention, because through the Colonial Charters they 
somewhat influenced the American written constitutions with which we are familiar. Cromwell's speech to Parliament is an interesting commentary upon the reasons for government and misgovernment during the English Revolution. Chapter XI. is intended to show the nature of the Colonial governments and their constitutional basis; for such a purpose no one English or Colonial official document could suffice, and a departure has been made from the general principle by including Dummer's Defence of the Charters, though it had no public sanction. This piece, taken in connection with the Virginia Bill of Rights (Chapter XIII.), builds the bridge between English and American institutions. Chapter XIX. is inserted in order to show the principle of constitutional limitations on the powers of the legislature, although the immediate question happens to be that of chartering a bank. The reasoning of the Federal Court has been applied to the principle of limited legislative powers over personal relations. Chapter XX. has its justification in the familiar truth that the Monroe Doctrine arose to a large degree out of the feeling that the blessings of free government should be assured to our Latin-American neighbours. In the final chapter, XXIV., the relation of free and popular government to the American colonies is brought out through the President's messages and speeches on West Indian and Philippine affairs, and the arguments of others for and against the policy he has thus enounced.

Many other documents might have been appropriately inserted, but the twenty-four which appear below have a special right to appear because of their own importance and because of their relation with each other. The book moves from beginning to end; each piece has a carefully considered place in the chain of human progress.

The Appendices deserve some special mention; one of them is the special text of the Habeas Corpus Act, alluded to above; another is the necessary list of authors quoted, showing pre- 
cisely the editions used in each case, and thus making it easy to enlarge the extracts. For two others, Miss Hill has prepared an Outline of Essentials in English and American History, an expansion of a smaller list long used in her own teaching. This outline is intended to show the relation of the constitutional documents to narrative history, and thus to put them on a proper background.

How shall Liberty Documents be most effectively used? For the reader of history who likes to have at hand the text of the great documents which he finds mentioned, this edition is especially serviceable, because, together with the text, he has the illustrative comment which makes clear the whole ground. Hence it may perhaps find a place in school, public, and private libraries.

The most obvious use of such a book is to be the backbone of a course in English and American constitutional development, the Outlines in the Appendix serving for an analysis of the whole subject, while the documents are to be a subject of study and thought. Among the many collections of this kind there is perhaps no other which brings together the materials for a judgment of so many great constitutional principles; for, besides the text, the references at the end of each piece carry the student to the best contemporaries and the best modern writers. In a certain sense the book is a little historical library, which, like all other libraries, is intended first to satisfy and then to make discontented, first to furnish the material necessary for the student and then to arouse him to search for more material.

In any course in English history the book is available, first, because of its careful reprint of the greatest English constitutional documents; second, because of the side-notes, which call attention to the development of constitutional thought and practices. The documents are all such as will be useful to pupil and student; and the great lesson is enforced that the 
guarantees of English liberty extended also to the colonies, and through them were worked out in our own political system.

In connection with a course in American Constitutional History the book is useful because it makes easy the preliminary study of the basis of American free institutions, in the practice and the concrete records of England; and fourteen of the twenty-four chapters are devoted to distinctively American utterances.

After all, the usefulness of a collection, like the usefulness of a text-book, depends, to a large degree, upon the teacher. One who is awakened to the importance of constitutional development, to the study of charters and statutes and constitutions, as expressing the aspirations of the people, will know how to show young people that that side of history is interesting. Perhaps, also, in these days of storm and stress, of the creation of new political powers and influences, of undreamed complications with the affairs of the rest of the civilized world, it may be worth while to bring to the minds of young people the truth that our personal liberty, onr freedom to move about, to take up callings, and to make the most of ourselves, is not a privilege which defends itself; that it behooves a free people not to give up principles for which they and their forefathers have been contending during more than eight centuries.

ALBERT BUSHNELL HART. 


\section{CONTENTS}

\section{CHAPTER I}

CORONATION OATH AND CHARTER OF HENRY I. (1101)

\section{Suggestions}

Documents :-

The Coronation Oath (1100)

The Charter of Henry I. at his Coronation (1101) . . . . . . 2

Contemporary Exposition:-

William of Malmesbury, Chronicles of the Kings of England. 5

Roger of Wendover, Flowers of History . . . . . . . . 6

\section{Critical Comment :-}

Hallam, Europe during the Middle Ages . . . . . . . . . 7

Stubss, Constitutional History of England . . . . . . . . 7

Green, Short History of the English People . . . . . . . . 7

Pollock and Maitland, History of English Law . . . . . 7

Rassome, Advanced History of England . . . . . . . . . 8

Gardiner, Student's History of England . . . . . . . . . 8

\section{CHAPTER II}

\section{MAGNA CHARTA (1215)}

\section{Suggestions}

Document : -

Magna Charta (June 15, 1215) . . . . . . . . . . . 9

\section{Contemporary Exposition:-}

ROger of Wendover, Flowers of History . . . . . . . . 25

\section{Critical Comment :-}

Coke, First Institute of the Laws of England . . . . . . . . 27

Burke, Works . . . . . . . . . . . . . . . . . 27

Halda m, Europe during the Middle Ages . . . . . . . . . 27

Palgrave, English Commonwealth . . . . . . . . . . 27

Mackintosh, History of England . . . . . . . . . . . 28

Stunвs, Constitutional History of England . . . . . . . . 29

Green, Short History of the English People . . . . . . . . 29 
Critical Comment, continued:- Pagr

Bagenot, English Constitution . . . . . . . . . . . . 31

Taswell-Langmead, English Constitutional History . . . . . 31

Von Gness, History of the English Parliament . . . . . . 32

Pollock and Mattlaxd, History of English Law . • . . . 32

Gardiner, Student's History of England . . . . . . . . . 32

Runsome, Advanced History of England . . . . . . . . . 32

\section{CHAP'TER III}

\section{THE SUMMONS TO PARLIAMENT (1295)}

Suggestions .

Document :-

Summons to Parliament (Oct. 3, 1295) . . . . . . . . . . 34

Contemporary Exposition:-

Thomas Cromweld, Letter to John Creke . . . . . . . . 35

Summons in reign of Henry VIII. . . . . . . . . . . . 36

\section{Critical Comment :-}

Halcas, Europe during the Middle Ages . . . . . . . . . 37

StubBs, Constitutional History of England . . . . . . . . . 38

Taswell-Langmead, English Constitutional History . . • . . 38

Hosmer, Anglo-Saxon Freedom . . . . . . . . . . 38

BoutMy, English Constitution . . . . . . . . . . . . 39

Freeman, House of Lords . . . . . . . . . . . . . . 39

RANsome, Advanced History of England . . . . . . . . . 39

Gardiner, Student's History of England . . . . . . . . . 40

Adams, Critical Period of English Constitutional History . . . 40

\section{CHAPTER IV}

\section{CONFIRMATIO CHARTARUM (1297)}

\section{Suggestions}

Document : -

"Confirmatio Chartarum" of Edward I. (Nov. 5, 1297) . . . . 43

\section{Contemporary Exposition:-}

Bartholomew de Cotron, Historia Anglicana . . . . . 45

\section{Critical Comment :-}

Halla m, Europe during the Middle Ages . . . . . . . . . 45

Macaulay, History of England . . . . . . . . . . . . 46

Stubss, Constitutional History of England . . . . . . . . 46

Tasweld-Langmead, English Constitutional History . . . . . 46

Feilden, Short Constitutional History of England . . . . . . 47

Von Gneist, History of the English Parlinment . . . . . . . 47

TAYLOR, Origin and Growth of the English Constitution . . . . 47 


\section{CHAPTER V}

LEGAL FORMS AND JURY TRIALS (1429)

Suggestions .

PAGE

Document :-

Statute: 8 Henry VI. Cap. 12 (1429) . . . . . . . . . . 49

Contemporary Exposition:-

Sir John Fortescue, De Laudibus Legum Anglice . . . . . 5]

Christopher Saint-German, Doctor and Student . . . . . 54

Critical Comment:-

Blackstone, Commentaries on the Laws of England . . . . . 54

SPExce, Equitable Jurisdiction of the Court of Chancery . . . 56

Forsxth, History of Trial by Jury . . . . . . . . . . . 57

Green, Short History of the English People . . . . . . . . 59

Taswelr-Langmead, English Constitutional History . . . . . 60

TAY LOR, Origin and Growth of the English Constitution . . . . 63

Stevens, Sources of the Constitution of the United States . . . 65

\section{CHAP'TER VI}

\section{PETITION OF RIGHT (1628)}

Suggestions . . . . . . . . . . . . . . . . . . . 66

Document :-

Petition of Right (June 7, 1628) . . . . . . . . . . . 67

Contemporary Exposition:-

Cirardes I., Speech at Prorogation of Parliament (June 26, 1628) 72

Critical Comment :-

Hallam, Constitutional History of England . . . . . . . 72

Nugent, Memorials of Hampden ․ . . . . . . . . . 72

Macaulay, History of England . . . . . . . . . . . . 74

Creasy, Rise and Progress of the English Constitution . . . . 74

TAYLOR, Origin and Growth of the English Constitution . . . . 75

Von Gneist, History of the English Parliament . . . . . . 76

Gardiner, Constitutional Documents of the Puritan Revolution . . 76

Hosmer, Anglo-Saxon Freedom . . . . . . . . . . . . 77

\section{CHAP'TER VII}

\section{ENGLISH WRITTEN CONSTITUTIONS (1648-1653)}

Suggestions

Documents :-

The Agreement of the People (Jan. 15, 1649) . . . . . . . . 79

The Instrument of Government (Dec. 16, 1653) . . . . . . . 85 
Contemporary Exposition:-

Oliver Cromwell, First Speech to the Sixth Parliament . . . 98

\section{Critical Comment :-}

Hallam, Constitutional History of England . . . . . . . . 100

Maca dlay, History of England . . . . . . . . . . . 100

BAGEHOT, English Constitution. . . . . . . . . . . . 101

Green, Short History of the English People . . . . . . . . 101

Taswell-Langmead, English Constitutional History . . . . . 103

Taylor, Origin and Growth of the English Constitution . . . . 103

Gardiner, Constitutional Documents of the Puritan Revolution . . 104

Hosmer, Anglo-Saxon Freedom . . . . . . . . . . . . 109

Borgenud, Adoption and Amendment of Constitutions . . . . 111

Borgeaud, Rise of Modern Democracy . . . . . . . . . 111

Rassome, Advanced History of England . . . . . . . . . 112

Meduex, Student's Manual of English Constitutional History . . 113

\section{CHAPTER VIII}

\section{HABEAS CORPUS ACT (1679)}

Suggestions . . . . . . . . . . . . . . . . . . 115

Document :-

Habeas Corpus Act (1679) . . . . . . . . . . . . . . 115

Contemporary Exposition:-

Bishop Gilbert Burnet, History of His Own Time . . . . 117

\section{Critical Comment :-}

Buackstone, Commentaries on the Laws of England . . . . . 118

Creast, Rise and Progress of the English Constitution . . . . 118

Hurd, Right of Personal Liberty . . . . . . . . . . . 118

Paterson, Liberty of the Subject, etc. . . . . . . . . . . 119

Taswell-Langmead, English Constitutional History . . . . . 119

Dicex, Study of the Law of the Constitution . . . . . . . 120

MAY, Constitutional History of England . . . . . . . . 120

TAYLOR, Origin and Growth of the English Constitution . . . . 121

\section{CHAPTER IX}

THE BILL OF RIGHTS (1689)

Suggestions

Document : -

The Bill of Rights (Oct. 25, 1689) . . . . . . . . . . . 122 
Contemporary Exposition:-

Bishop Gilmert Burnet, History of His Own Time . . . . 132

\section{Critical Comment:-}

Lufrman, Citizen and Goldsmith . . . . . . . . . . 132

Guizot, General History of Civilization . . . . . . . . 133

MACAULAY, History of England . . . . . . . . . . . 133

Green, Short History of the English People . . . . . . . . 134

Taswell-Langmead, English Constitutional History . . . . . 134

TAxLOR, Origin and Growth of the English Constitution . • . . 135

Hosmer, Anglo-Saxon Freedom . . . . . . . . . . . . 135

Stevens, Sources of the Constitution of the United States . . . 136

RᄉNsome, Advanced History of England . . . . . . . . . 136

\section{CHAPTER $\mathrm{X}$}

\section{ACT OF SETTLEMENT (1700-1701)}

Suggestions .

Document : -

Constitutional Provisions in the Act of Settlement (1700-1701) . . 138

\section{Contemporary Exposition:-}

Bisnop Gilbert Burnet, History of His Own Tinie . . . . 140

\section{Critical Comment :-}

Buackstone, Commentaries on the Laws of England . . . . . 140

DrCey, Study of the Law of the Constitution . . . . . . . . 141

Ransome, Advanced History of England. . . . . . . . . 141

\section{CHAP'TER XI}

\section{SPIRIT OF COLONIAL RIGHTS (1721-1765)}

\section{Suggestions}

Document :-

Extracts from "A Defence of the New-England Charters" (1721) . 142

\section{Contemporary Exposition:-}

Axonxmous, A Plain State of the Argument between Great

Britain and her Colonies . . . . . . . . . . . . 144

Axonymous, Proposals for Uniting the English Colonies on the

Continent of America . . . . . . . . . . . . 146

Thomas Pownall, Administration of the Colonies (1765) . . . 147

Axonymous, America's Appeal to the Impartial World . . . . 148

\section{Critical Comment :-}

WALSII, An Appeal from the .Iudgments of Great Britain . . . 150

Marshall, History of the Colonies Planted by the English . . . 152

Trwaltes, The Colonies . . . . . . . . . . . . 153 


\section{CHAPTER XII}

\section{THE STAMP ACT CONTROVERSY (1765)}

Suggestions .

Document :-

Declaration of Rights and Grievances of the Colonists in America (Oct. 7, 1765)

Contemporary Exposition:-

Benjamin Franklin's Examination relative to the Repeal of the American Stamp Act . . . . . . . . . . . . . 158

Ja mes Otıs, Rights of the British Colonies . . . . . . . . 159

Sir William Keith, Two Papers on the Subject of Taxing the British Colonies in America . . . . . . . . . . . . 160

Josian Tucker, Letter from a Merchant in London to his Nephew in America . . . . . . . . . . . . . . . . . 161

Edmund Burke, Speech on Conciliation with America . . . . 162

William Pitt, Earl of Chatham, Speech in the House of Lords . . . . . . . . . . . . . . . . 163

William Bollen, in Journals of Congress (1775) . . . . 164

Critical Comment :-

MaCAutay, The Earl of Chatham . . . . . . . . . . 164

Chamberlain, The Revolution Impending . . . . . . . . 164

\section{CHAPTER XIII}

\section{VIRGINIA BILL OF RIGHTS (1776)}

\section{Suggestions}

Document : -

A Declaration of Rights (June 12, 1776) . . . . . . . . . 166

\section{Contemporary Exposition :-}

George Washington, Works . . . . . . . . . . 169

John Adams, Works . . . . . . . . . . . . 170

\section{Critical Comment:-}

Hitchcock, American State Constitutions . . . . . . . 173

JAMEson, Treatise on Constitutional Conventions . . . . . . 174

Curtis, Constitutional History . . . . . . . . . . . . . . 174

Borgenud, Adoption and Amendment of Constitutions . . . . 176

Bryce, American Commonwealth . . . . . . . . . . . 177

Schouler, Constitutional Studies . . . . . . . . . . . . 178

Fisher, Evolution of the Constitution of the United States . . . 178

Thorpe, Constitutional History of the American Republic . . 179

Channing, Students' History of the United States . . . . . 180 


\section{CHAPTER XIV}

\section{DECLARATION OF INDEPENDENCE (1776)}

Suggestions

Document :-

The Declaration of Independence (July 4, 1776) . . . . . . . 183

Contemporary Exposition:-

John Adams, Familiar Letters . . . . . . . . . . . . 188

David Ramsay, American Revolution . . . . . . . . . 191

Thomas Jefferson, Works . . . . . . . . . . . . 192

Critical Comment:-

WeBster, Works . . . . . . . . . . . . . . 192

Storr, Commentaries . . . . . . . . . . . . . 197

Livermore, An Historical Research . . . . . . . . . . 197

Green, Short History of the English People . . . . . . . . 197

Von Holst, Constitutional History of the United States . . . . 198

LECK Y, England in the Eighteenth Century . . . . . . . . 199

Ellis, in Winsor, Narrative and Critical History of America . . 200

Fiske, American Revolution . . . . . . . . . . . . . 202

Lodge, American Revolution . . . . . . . . . . . 202

\section{CHAPTER XV \\ THE ARTICLES OF CONFEDERATION (1781)}

Suggestions 204

Document:-

Articles of Confederation (1781) . . . . . . . . . . 204

Contemporary Exposition:-

Pelatiali Webster, Remarks on a Pamphlet . . . . . . . 216

George Washington, Works . . . . . . . . . . 218

Alexander Hamilton, Works . . . . . . . . . . . . 219

Thomas JefFerson, Works . . . . . . . . . . . . . 219

Critical Comment:-

Storx, Commentaries . . . . . . . . . . . . . . 220

JA Meson, Treatise on Constitutional Conventions . . . . . 221

Mulford, The Nation . . . . . . . . . . . . . . . 221

Von HoLst, Constitutional History of the United States . . . . 223

HART, Federal Government . . . . . . . . . . . . . 224

Forv, Rise and Growth of American Politics . . . . . . . . 225

Stevens, Sources of the Constitution of the United States . . . 225

Fiske, Critical Period of American History . . . . . . . . 225

Fisier, Evolution of the Constitution of the United States , , . 226 


\section{CHAPTER XVI}

THE NOR'THWEST ORDINANCE (1787)

Suggestions

Document:-

The Ordinance of 1787 . . . . . . . . . . . . . . . 228

Contemporary Exposition:-

Nathax Dane, in the Cutlers' Life of Manasseh Cutler . . . . 237

Critical Comment:-

Webster, Works . . . . . . . . . . . . . . . 238

Chase, Sketch of the History of Ohio . . . . . . . . . . 239

Bancroft, History of the United States . . . . . . . . . 240

Burnet, Early Settlement of the Northwest Territory . . . . . 240

Honr, Oration at Centennial at Marietta . . . . . . . . . 240

HinsDale, The Old Northwest . . . . . . . . . . 241

Cutlers, Life of Manasseh Cutler . . . . . . . . . . . 242

\section{CHAPTER XVII}

THE CONSTITUTION OF THE UNITED STATES (1787)

Suggestions . . . . . . . . . . . . . . . 244

Document:-

Constitution of the Cinited States of America (Sept. 17, 1787) . . 245

Cuntemporary Exposition:-

Bendamin Franklin, Speech on the Last Day . . . . . . . 264

George Mason, Address to the Citizens of Virginia . . . . . 267

The Federalist (No. XLV.) . . . . . . . . . . . . 267

Alexander Hamilton, Works . . . . . . . . . . . . 268

George Washington, Works . . . . . . . . . . . 269

John Dickinson, Fabius Letters . . . . . . . . . . . $27 \mathrm{I}$

Tencr Coxe, Examination . . . . . . . . . . . . . 271

Thomas Jefferson, Works . . . . . . . . . . . . 272

Critical Comment:-

WeBster, Works . . . . . . . . . . . . . . . 273

Storr, Commentaries . . . . . . . . . . . . 274

Guadstone, Kin Beyond Sea . . . . . . . . . . . . . 275

Cooley, Constitutional Law . . . . . . . . . . . . . 276

Hurd, Theory of our National Existence . . . . . . . . . 278

Sмıтн, in Jameson's Essays on Constitutional History . . . . . 279

HART, Federal Government . . . . . . . . . . . . . . 280

Stevens, Sources of the Constitution of the United States . . . 281

Bryce, American Commonwealth . . . . . . . . . . . . 282

Thorpe, Constitutional History of the American People . . . . 283

McLudghlix, Social Compact and Constitutional Construction . . 284 


\section{CHAPTER XVIII}

WASHINGTON'S FAREWELL ADDRESS (1796)

Suggestions

Document:-

Washington's Farewell Address to the People of the United States

(Sept. 17, 1796) . . . . . . . . . . . . . 286

Contemporary Exposition :-

Jonathan Mrtchell Sewall, Oration . . . . . . . 306

Thomas Paine, Oration . . . . . . . . . . . . . 307

Joseph BLYth, Eulogy . . . . . . . . . . . . . . . 308

John M. MAson, Oration . . . . . . . . . . . 308

George R. Mrnot, Oration . . . . . . . . . . 308

\section{Critical Comment :-}

SParks, George Washington . . . . . . . . . . . . 309

Binsex, Inquiry into the Formation of Washington's Farewell

Address . . . . . . . . . . . . . . . . . . 309

OLxex, Growth of our Foreign Policy . . . . . . . . . . 310

\section{CHAPTER XIX}

THE EXTENT OF FEDERAL POWERS (1819)

Suggestions .

Document:-

Decision in the Case of $M^{\prime}$ Culloch vs. the State of Maryland

Contemporary Exposition:-

Anonymous, in Niles' Weekly Register . . . . . . . . 316

Critical Comment:-

STORY, Commentaries . . . . . . . . . . . . . 318

HAre, American Constitutional Law . . . . . . . . . . . 319

WrLlovg нвт, Supreme Court of the United States . . . . . . 319

SUMNer, History of Banking in the United States . . . . . . . 319

\section{CHAPTER XX}

LIBERTIES OF OTHER AMERICAN PEOPLES (]823)

\section{Suggestions}


Contemporary Exposition:-

John Quncy AdaMs, Memoirs . . . . . . . . . 323

Thomas Jefferson, Complete Works . . . . . . . . , 325

Janes Madison, Works . . . . . . . . . . . 326

Daniel Wenster, Works. . . . . . . . . . 327

\section{Critical Comment: -}

DANA, Wheaton's Elements of International Law . . . . . . 329

Von Holst, Constitutional History of the United States . . . . 329

Morse, John Quincy Adams . . . . . . . . . . 330

Gilman, James Monroe . . . . . . . . . . . . 331

Schour.er, History of the United States . . . . . . . . . 332

Tucker, The Monroe Doctrine . . . . . . . . . . . . 333

Cleveland, Special Message, Dec. 17, 1895 . . . . . . . 334

Olnex, Letter to Mr. Bayard . . . . . . . . . . . . . 334

Woolser, America's Foreign Policy. . . . . . . . . . 336

McMaster, With the Fathers . . . . . . . . . . . 337

Reddaway, The Monroe Doctrine . . . . . . . . . 337

HART, The Monroe Doctrine . . . . . . . . . . . . . 338

\section{CHAPTER XXI}

\section{THE RIGHTS OF SLAVES AND OF THEIR RACE (1857)}

\section{Suggestions}

Documents:-

Extracts from the Opinion of the Court in the Dred Scott Decision

(March 6, 185i) . . . . . . . . . . . . . . . 340

Extract from Justice Benjamin R. Curtis, dissenting (1857) . . 346

Contemporary Exposition:-

T. H. Benton, Examination of the Decision in the Dred Scott Case 349 .

George Bancroft, in Pulpit and Rostrum . . . . . . . . 351

Horace Greelex, American Conflict . . . . . . . . . . 352

Henry Wilsov, Rise and Fall of the Slave Power in America . 353

Critical Comment:-

Von Houst, Constitutional History of the United States . . . . 354

Schouler, History of the United States . . . . . . . . . 354

Rhodes, History of the United States . . . . . . . . . . 356

Bryce, American Commonwealth . . . . . . . . . . 356

\section{CHAPTER XXII}

\section{EMANCIPATION OF THE SLAVES (1862-1863)}

Suggestions .

\section{Documents : -}

Preliminary Proclamation of Emancipation (Sept. 22, 1862) • . 358

Final Proclamation of Emancipation (Jan. 1, 1863) . . . . . , 362 
J. A. Cravens, Speech in House of Representatives against Emancipation . . . . . . . . . . . . . . . . . . . 364

Benjamin F. Thomas, Speech in House of Representatives for Emancipation . . . . . . . . . . . . . 365

U. S. Grant, General Order . . . . . . . . . . . . . 366

F. B. Carpenter, Six Months at the White House. . . . . . 366

Critical Comment:-

Johrston, The United States: Its History and Constitution . . 367

NicOlay AND HAY, Abraham Lincoln: A History . . . . . 368

Pierce, Menoir and Letters of Charles Sumner . . . . . . 369

Dunsivg, Essays on the Civil War and Reconstruction . . . . 369

Morse, Abraham Lincoln . . . . . . . . . . . . . . 370

MCCALL, Thaddeus Stevens . . . . . . . . . . . . 370

BANCROFT, Life of William II. Seward . . . . . . . . . 371

TARBELL, Life of Abraham Lincoln . . . . . . . . . . . 371

\section{CHAPTER XXIII}

THE RECONSTRUCTION AMENDMENTS (1865-1870)

Suggestions

373

Documents :-

Thirteenth Amendment (1865) . . . . . . . . . . . 373

Fourteenth Amendment (1868) . . . . . . . . . . . . . 373

Fifleenth Amendment (1870) . . . . . . . . . . . 375

Contemporary Exposition :-

A. H. Coffrotir, of Pennsylvania, in Congressional Globe . - 375

J. S. Brown, of Wisconsin, in Congressional Globe . . . . 376

James G. Blaine, Twenty Years of Congress . . . . . . 376

Critical Comment:-

Loweld, Prose Works . . . . . . . . . . . . . . 380

Cooler, Constitutional Law . . . . . . . . . . . . 381

Bryce, American Commonwealth . . . . . . . . . 381

Dunning, Essays on the Civil War and Reconstruction . . . . 382

McLa vgirin, History of the American Nation . . . . . . . 384

Hart, Salmon Portland Chase . . . . . . . . . . . 386

\section{CHAPTER XXIV}

\section{IIBERTY IN UNITED STATES COLONIES AND DEPENDEN- CIES (1898-1899)}

Suggestions 388

Documents :-

Extracts from President McKinley's Annual Message (Dec. 5, 1898) 388

Extracts from President McKinley's Annual Message (Dec. 5, 1899) 392 
Contemporary Exposition :-

PAGE

President William McKinley, Home Market Speech . . . 398

Secretary John D. Long, Home Market Speech . . . . . 399

Richard Otxey, Growth of our Foreign Policy . . . . . . 401

\section{Critical Comment :-}

AdAMs, Imperialism . . . . . . . . . . . . . . . 402

Randolph, Foreign Policy of the United States . . . . . . . 403

Sumner, Conquest of the United States by Spain . . . . . . 404

Schurz, American Imperialism . . . . . . . . . . . . 406

Hoar, No Constitutional Power to conquer Foreign Nations . . . 408

Burgess, How may the United States govern its Extra-Continental

Territory? . . . . . . . . . . . . . . . 411

Hart, Territorial Problems . . . . . . . . . . . . . 412

Аввотт, Expansion, but not Imperialism . . . . . . . . 414

LoDge, Retention of the Philippine Islands . . . . . . . . 416

Giddings, Democracy and Empire . . . . . . . . . 421

\section{APPENDICES}

APPENDIX A. - Essentials in English Constitutional History 423

APPENDIX B.-Essentials in American Constitutional HisTORY . . . . . . . . . . . . . . . . . . 427

APPENDIX C. - Text of the Habeas Corpus Act, 1679 . . . 431

APPEndiX D. - List of Authors Cited . . . . . . . . 440

INDEX . . . . . . . . . . . . . . . . . . 449 


\title{
LIBERTY DOCUMENTS
}

\author{
Chapter I \\ CORONATION OATH AND CHARTER \\ OF HENRY I. (1101)
}

\section{SUGGESTIONS}

TIIIs Charter was published by Henry I. on his accession to the Crown. Copies were despatched to the several counties and deposited in the principal monasteries. The Charter is in form an amplification of his Coronation Oath, the exact words of which are found in the form used at the Coronation of King Ethelred II. [978-1016].

Before reading the Coronation Oath and Charter of Liberties of Henry I. the elementary history of Teutonic migration should be examined critically, and the causes which led the Teuton to settle in Britain should be noted.

The partial amalgamation of the Teutonic people with the Celtic aborigines in Britain during the period of the Heptarchy; the strong characteristics of love of liberty and freedom of government which mark the race throughout its political history, and which are discoverable in their primitive institutions; the development of the land tenure; and the feudal system as individualized by William I. in organizing Norman rule in England; - each of these essential historical conditions must be examined before this document and Henry's policy can be fully understood.

The charter itself demands attention before other documents can be considered, because it contains, though possibly unnoticeable at the first reading, the great doctrine of the future - the equality in rights of freemen.

For Topics covering such expository reading note Essentials in Early Teutonic History, Appendix A.

\section{DOCUMENTS}

\section{The Coronation Oath (rroo)}

In the name of Christ I promise these three things William to the Christian people over whom I rule. In the Stubbs; Select first place that $I$ will endeavour and use all material translated by means in order that the Church of God and all the Henry A. people of Christ maty enjoy a true peace under our Sup. Jud. Ct. government for all time; next, that I will interdict of Mass. (1900) 
robbery and all forms of injustice; third, that in all judicial proceedings $I$ will advance justice and mercy, in order that to me and you the gracious and merciful God may extend his mercy.

\section{The Charter of Henry I. at his Coronation (1101)}

The Statutes of the Realm, I. 1 ,translated by Henry A. Clapp. (1900)

In form an amplification of the covenant made by the king in his coronation oath. This is the only legislative enactment during the reign of Henry I. See Magna Charta, Art. i
In the year of the Incarnation of our Lord one thousand one hundred and one. Henry, son of King William, after the death of his brother William, by the grace of God King of the English, to all the faithful sends greeting.

1. Know ye that $I$ have been, by the mercy of God and by the barons in council, crowned king of this same kingdom of all England; and since the kingdom has been oppressed by unjust exactions I, through the fear of God and the love I have towards you, do in the first place make free the holy church of Grod, so that I will neither sell nor put to rent, nor upon the death of an archbishop or of a bishop or of an abbot will I accept anything from the demesne of the church or from its men until a successor has taken the place. And all eril customs by which the kingdom of England has been unjustly oppressed I will do away with, -

The Vassals: see Magna Charta, Art.ii "Men" wherever used in this charter means "feudal dependents."

Relief," a payment in money to the king by the incoming heir upon admission into an inheritance. This was demanded by which evil customs I herein indicate:

2. If any one of my barons, or of my earls, or of any other rassal who hold their estates of me shall die, his heir shall not redeem his land as he did in the time of my brother, but shall relieve said land by just and lawful reliefs. In like manner the men of my barons shall relieve their lands from those of whom they hold, by a just and lawful relief.

3. And if any of my barons, or of any other of my men, shall wish to give in marriage his daughter, or his sister, or his niece or other female relations, let him consult me in the matter; but neither will I receive anything from him for the permission nor 
will I forbid him to give her in marriage unless he Henry I., as shall wish to join her to one of my enemies. And by his predeif upon the death of a baron, or of any other of the promise if a here made is my men, a daughter shall survive as his heir I will a return to give her in marriage with her lands, after taking the equitable counsel of my barons. And if, upon the death old custom of a man, his wife shall survive and shall be cruel exacwithout children she shall have her dowry and tions made in the reigns right to marry, and I will not give her in mar- of Wm. I. riage to any husband except in accordance with her wish.

4. If a wife with children shall survive her husand $\mathrm{Wm}$. II.

Marriage: see Magna band, such a one shall have her dowry and right to Art. viii. marry whilst she properly preserves her relation (to the king as lord paramount), and I will not give her in marriage except in accordance with her wish. And the guardian of the estate and the children shall be either the wife or some one of the near kindred who ought justly so to be. And I direct that my barons conduct themselves in like manner towards the sons, daughters, or wives of their men,

5. The common tribute for mintage which was collected through cities and counties and which was not known in the time of King Edward, this shall not be from henceforth, and I altogether forbid it. If any one, whether an officer of the mint or another, be taken with false money about him, let due justice be done in the matter.

6. All suits and dues which were owing to my brother I forgive, excepting my just rents, and excepting those which were agreed upon for the inheritances of others or for those properties which more justly pertained to others. And if any one has agreed to give anything on account of his own inheritance, that I forgive, together with all reliefs which were agreed to be given for actual inheritances.

"Common tribute" (monetagium) was a payment by the subjects to prevent depreciation or change of coinage. 
See Magna Charta, Art. xxvii.

The estate was to be distributed as the deceased ought to distribute it, - a portion to the church included.

See Magna Charta, Art. $\mathrm{xx}$.

7. And if any of my barons or feudal dependents shall fall sick, according as he shall give away or shall arrange to give away his money, I concede that it shall be given. But if, prevented by military service or physical infirmity, he shall not give away his money or arrange to give it, his wife or children or relatives and lawful heirs shall divide it np for the good of his soul as shall seem best to them.

8. If any of my barons or feudal dependents shall incur a forfeiture, he shall not give surety in the way of an arbitrary mulct of money as he did in the time of my father or my brother, but according to the mode of forfeiture he shall make reparation as he would have made it before my father's time, in the time of my other predecessors. But if he shall have been convicted of treason or an infamous crime, as shall be just so he shall make reparation.

9. All murders previous to the day of my coronation I pardon, and for those which shall be committed henceforth just reparation shall be made according to the law of King Edward.

The only un- 10. The forests I have, with the general consent popular clause in the charter. William I.

Edward the Confessor, 1042.

This article is really intended to protect the of my barons in council, retained in my own possession as my father held them.

11. To soldiers who hold their lands by knightly service I give such lands as of my own gift, all arable portions of the same to be free from all amercement and other burdens, that as they are thus substantially relieved they may keep themselves well furnished both with horses and arms for my service and the defence of my kingdom.

12. I establish and henceforth undertake to maintain a firm peace in all my kingdom.

13. I give back to you the law of King Edward, with those emendations which my father with the council of his barons made upon it.

14. If any one has taken aught from my property or the property of another since the death of my brother William, let it all be restored at once with- 
out other amends; and if any one hereafter shall privileges of retain anything thus taken, he shall make heary the people. restitution above what shall be found to have been taken.

\section{WITNESSES :-}

Maurice bishop of London,

Gundolf bishop,

William bishop elect,

Henry earl,

Simon earl

Walter Giffard,

Robert de Montfort,

Roger Bigot,

Henry de Portous,

at London when I was crowned.
Note the few witnesses compared with Magna

Charta.

This charter was renewed by Stephen and Henry

II., and served in John's reign as the text upon which the barons founded their claim for restoration of " an. cient liberties."

\section{CONTEMPORARY EXPOSITION}

WILLIAM OF MALMESBURY (1135)

. . He (Henry) was elected king: though some trifling dissensions had first arisen among the nobility, which were allayed chiefly through the exertions of Henry, Earl of Warwick. . . .

$\mathrm{He}$ immediately promulgated an edict throughout England, annulling the illegal ordinances of his brother, and of Ranulph; he remitted taxes; released prisoners; drove the flagitious from court; restored the nightly use of lights within the palace, which had been omitted in his brother's time; and renewed the operation of the ancient laws, confirming them with his own oath, and that of the nobility, that they might not be eluded.

A joyful day then seemed to dawn on the people, when the light of fair promise shone forth after such repeated clouds of distress.

William of Malmesbury, Chronicles of the Kings of England. (Giles's 'Translation) V. 125. 
To induce them (the barons) to espouse his cause and make him king, he promised them to revise and amend the laws by which England had been oppressed in the time of his deceased brother. 'To this the clergy and people replied that, if he would confirm to them by charter all the liberties and customs which were observed in the reign of the holy King Edward, they would accede to his wishes and make him their king. This Henry readily engaged to do, and, confirming the same by an oath, he was crowned king at Westminster, on the day of the Annunciation of St. Mary, with the acelamations of the clergy and people; after which he caused these principles to be reduced to writing, to the honour of the holy church and the peace of his people. ...

There were as many of these charters made as there are counties in England, and by the king's orders they were placed in the abbeys of each county for a memorial.

ROGER OF Wendover, Flowers of History. (Giles's Translation) I. 448.

\section{CRITICAL COMMENT}

HALLAM (1818)

Nor does the charter of Henry I., though so much celebrated, contain anything specially expressed but a remission of unreasonable reliefs, wardships, and other feudal burdens. It proceeds, however, to declare that he gives his subjects the laws of Edward the Confessor, with the emendations made by his father with consent of his barons. . . .

The people had begun to look back to a more ancient standard of law. The Norman conquest, and all that ensued upon it, had endeared the memory of their Saxon government. Its disorders were forgotten, or rather were less odions to a rude nation, than the coercive justice by which they were afterward restrained. Hence it became the favourite cry to demand the laws of Edward the Confessor; and the Normans themselves, as they grew dissatisfied with the royal administration, fell into 
these English sentiments. But what these laws were, or more properly, perhaps, these customs, subsisting in the Confessor's age, was not very distinctly understood.

So far, however, was clear, that the vigorous feudal servitudes, the weighty tributes upon poorer freemen, had never prevailed before the conquest. In claiming the laws of Edward the Confessor, our ancestors meant but the redress of grievances which tradition told them had not always existed.

Hevry Hallam, Europe During the Middle Ages. I. 340.

STUBBS (1873)

The understanding to govern well was made not only with the archbishop as the first constitutional adviser of the crown, but with the whole nation; it was embodied in a charter addressed to all the faithful, and attested by the witan who were present, the paucity of whose names may perhaps indicate the small number of powerful men who had as yet adhered to him. . . . The form of the charter forcibly declares the ground which he was taking. . . . Perhaps the most significant articles of the whole document are those by which he provided that the benefit of the feudal concessions shall not be engrossed by the tenants in chief: ' in like manner shall the men of my barons relieve their lands at the hand of their lords by a just and lawful relief.'

Willidam StubBs, Constitutional History of England. I. 330.

J. R. GREEN (1874)

Henry's charter is important, not merely as the direct precedent for the Great Charter of John, but as the first limitation which had been imposed on the despotism established by the conquest.

J. R. Green, Short History of the English People. Chap. II., Sec. VI., p. 91.

POLLOCK AND MAITLAND (1895)

During the whole Norman period there was very little legislation. . . It seems probable that Rufus set the example of granting charters of liberties to the people at large. In 1093, sick and in terror of death, he set his seal to some document 
that has not come down to us. Captives were to be released, debts forgiven, good and holy laws maintained. . . . Henry at his coronation, compelled to purchase adherents, granted a charter full of valuable and fairly definite concessions. $\mathrm{He}$ was going back to his father's ways. (William I.) . . . Above all the laga Eadwardi as amended by William I. was to be restored.

Pollock and Maitland, History of English Law. I. 73.

\section{RANSOME (1895)}

Henry's charter is a very important document, for it shows us what were the chief grievances of which nobles and clergy complained, and the way in which they might be remedied.

Crril Ransome, Advanced History of England. 112.

GARDINER (1895)

The charter of Henry I., which had been produced at St. Paul's the year before (1213), was again read, and all present swore to force John to accept it as the rule of his own government. . . .

Magna Charta, or the Great Charter, as the articles were called after John confirmed them, was won by a combination between all classes of freemen, and it gave rights to them all.

S. R. Gardiner, Student's History of England. 181. 


\section{Chapter II}

\section{MAGNA CHARTA (1215)}

\section{SUGGESTIONS}

This Charter, signed by King John, June 15th, 1215, was the result of the struggle between the king and the barons. Through the winter of 1215, the barons had presented themselves in arms before the king, and preferred their claims - a resumption of the old English customs and common law, against which the king was openly defiant. At Easter the barons again renewed their demands. London, Exeter, Lincoln - one by one - city and county joined the barons in defiance of the king. Unconditional submission followed the discussion of the document; it was agreed upon and signed in a single day. One copy of it still remains in the British Museum.

As Magna Charta forms the basis of all later English and American written statements of free institutions, the document as a whole should be read with care, although many of its articles have ceased to have a direct relation with present history. Each article illuminates the legal and constitutional status of the thirteenth century, and should be examined with that point in mind. Articles 12,36,39, and 40, the two fundamental principles of all later constitutional government, should be committed to memory, since they are many times referred to throughout this volume.

For Outlines and Material, see Appendix A.

\section{DOCUMENT}

Magna Charta (1215)

The Great Charter of King Join, Granted June 15, A. D. 1215.

John, by the Grace of God, King of England, The Statutes Lord of Ireland, Duke of Normandy, Aquitaine, of the Realm, I. and Count of Anjou, to his Archbishops, Bishops, literated Abbots, Earls, Barons, Justiciaries, Foresters, from E. S. Sheriffs, Governors, Officers, and to all Bailiffs, and (1853). 
his faithful subjects, greeting. Know ye, that we, in the presence of God, and for the salvation of our soul, and the souls of all our ancestors and heirs, and unto the honour of God and the advancement of Holy Church, and amendment of our Realm, by advice of our venerable Fathers, Stephen, Archbishop of Canterbury, Primate of all England and Cardinal of the Holy Roman Church ; Henry, Archbishop of Dublin; William, of London; Peter, of Winchester; Jocelin, of Bath and Glastonbury; Hugh, of Lincoln; Walter, of Worcester; William, of Coventry; Benedict, of Rochester - Bishops : of Master Pandulph, Sub-Deacon and Familiar of our Lord the Pope ; Brother Aymeric, Master of the Note the Knights-Templars in England; and of the noble great increase of the baronage Persons, William Marescall, Earl of Pembroke; William, Earl of Salisbury; William, Earl of between 1101 Warren; William, Earl of Arundel ; Alan de Galand 1215. loway, Constable of Scotland; Warin FitzGerald, Peter FitzHerbert, and Hubert de Burgh, Seneschal of Poitou; Hugh de Neville, Matthew FitzHerbert, Thomas Basset, Alan Basset, Philip of Albiney, Robert de Roppell, John Mareschal, John FitzHugh, and others, our liegemen, have, in the first place, granted to God, and by this our present Charter confirmed, for us and our heirs for ever :

The Church: 1. That the Church of England shall be free, and see Henry, have her whole rights, and her liberties inviolable; Art. I. and we will have them so observed that it may appear thence that the freedom of elections, which is reckoned chief and indispensable to the English Church, and which we granted and confirmed by our Charter, and obtained the confirmation of the same from our Lord the Pope Innocent III., before the discord between us and our barons, was granted of mere free will; which Charter we shall observe, and we do will it to be faithfully observed by our heirs for ever. 
2. We also have granted to all the freemen of Reliefs: see our kingdom, for us and for our heirs for ever, all Henry I.'s the underwritten liberties, to be had and holden by II. them and their heirs, of us and our heirs for ever: If any of our earls, or barons, or others, who hold of us in chief by military service, shall die, and at the time of his death his heir shall be of full age, and owe a relief, he shall have his inheritance by the ancient relief - that is to say, the heir or heirs Earl's or of an earl, for a whole earldom, by a bundred Baron's pounds; the heir or heirs of alief, £100. pounds; the heir or heirs of a baron, for a whole Knight's
barony, by a hundred pounds; the heir or heirs of a relief, £5. kuight, for a whole knight's fee, by a hundred shillings at most; and whoever oweth less shall give less, according to the ancient custom of fees.

3. But if the heir of any such shall be under age, Wardship: and shall be in ward, when he comes of age he shall see Henry have his inheritance without relief and without fine. Art. III.

4. The keeper of the land of such an heir being under age, shall take of the land of the heir none but reasonable issues, reasonable customs, and reasonable services, and that without destruction and waste of his men and his goods; and if he commit the custody of any such lands to the sheriff, or any other who is answerable to us for the issues of the land, and he shall make destruction and waste of the lands which he hath in custody, we will take of him amends, and the land shall be committerl to two lawful and discreet men of that fee, who shall answer for the issues to us, or to him to whom we shall assign them; and if we sell or give to any one the custody of any such lands, and he therein make destruction or waste, he shall lose the same custody, which shall be committed to two lawful and discrect men of that fee, who shall in like manner answer to us as aforesaid.

5. But the keeper, so long as he shall have the custody of the land, shall keep up the houses, parks, warrens, ponds, mills, and other things pertaining 
to the land, out of the issues of the same land; and shall deliver to the heir, when he comes of full age, his whole land, stocked with ploughs and carriages, according as the time of wainage shall require, and the issues of the land can reasonably bear.

6. Heirs shall be married without disparagement, and so that before matrimony shall be contracted, those who are near in blood to the heir shall have notice.

7. A widow, after the death of her husband, shall forthwith and withont difficulty have her marriage and inheritance; nor shall she give anything for her dower, or her marriage, or her inheritance, which her husband and she held at the day of his death; and she may remain in the mansion house of her husband forty days after his death, within which time her dower shall be assigned.

See Henry I.'s Charter, Art. III.

The Jews were the king's bondsmen: this is
8. No widow shall be distrained to marry herself, so long as she has a mind to live without a husband; but yet she shall give security that she will not marry without our assent, if she hold of us; or without the consent of the lord of whom she holds, if she hold of another.

9. Neither we nor our bailiffs shall seize any land or rent for any debt so long as the chattels of the debtor are sufficient to pay the debt; nor shall the sureties of the debtor be distrained so long as the principal debtor has sufficient to pay the debt; and if the principal debtor shall fail in the payment of the debt, not having wherewithal to pay it, then the sureties shall answer the debt; and if they will they shall have the lands and rents of the debtor, until they shall be satisfied for the debt which they paid for him, unless the principal debtor can show himself aequitted thereof against the said sureties.

10. If any one have borrowed anything of the Jews, more or less, and die before the debt be satisfied, there shall be no interest paid for that 
debt, so long as the heir is under age, of whomso- the beginever he may hold; and if the debt falls into our ning of hands, we will only take the chattel mentioned in against Jews. the deed.

11. And if any one shall die indebted to the Jews, his wife shall have her dower and pay nothing of that debt; and if the deceased left children under age, they shall have necessaries provided for them, according to the tenement of the deceased; and out of the residue the debt shall be paid, saving, however, the service due to the lords, and in like manner shall it be done touching debts due to others than the Jews.

12. No SCUTAGE or aid Shali. BE IMPOSED IN OUR KINGDOM, UNLESS BY TIIE GENERAL COUNCIL OF oUR KINGDOM; except for ransoming our person, making our eldest son a knight, and once for marrying our eldest daughter; and for these there shall be paid no more than a reasonable aid. In Note the like manner it shall be concerning the aids of the liberty given City of London. to London.

13. And the City of London shall have all its ancient liberties and free customs, as well by land as by water; furthermore, we will and grant that all other cities and boroughs, and towns and ports, shall have all their liberties and free customs.

14. AND For holding the general Council of The aids THE KINGDOM CONCERNING THE ASSESSMENT OF AIDS, given by eitiEXCEPT IN THE THREE CASES AFORESAID, AND FOR time to the the assessing of scutages, we sihall cause to Barons BE SUMMONED THE ARCHBISHOPS, BISHOPS, ABBOTs, gained them BE SUMAONED THE ARCHBISHOPS, BISHOPS, ABBOTS, this clause, EARLS, AND GREATER BARONS OF TIIE REALM, SIN- alld became GLY BY OUR LETTERS. AND FURTIERMORE, wE the germ of

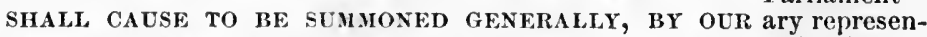
SHERIFFS AND BAILIFFS, ALI, OTHEIRS WHO HOLD tation in OF US IN CHIEF, FOR A CERTAIN DAY, TIIAT IS TO Hollse of SAY, FORTY DAYS BEFORE TILER MEETIXG AT LEAST, AND TO A CERTAIN PLACE; AND IN AL, LETTERS OF SUCI SUMNONS WE WILl DECLARE TIIE CAUSE OF 
Note the principle of the government: An hereditary sovereign, boun to summon and consult a parliament of the whole realm.

Services.

The Ct. of Com. Pleas met at Westminster from this time on.

Novel disseisin = dispossession.

Mort d'ancestor = death of the ancestor; that is, in cases of disputed succession to land.

Darrein Presentment $=$ last presentation to a benefice.

The word Assize here means "an assembly of knights or other substantial persons, held at a certain time and place where they sit with the Justice.

'Assisa" or

'Assize' is
SUCH SUMMONS. AND, SUMMONS BEING THUS MADE, THE BUSINESS SHALL PROCEED ON TIIE DAY APPOINTED, ACCORDING TO THE ADVICE OF SUCH AS SHALL BE PRESENT, ALTHOUGII ALL THAT WERE SUMMONED COME NOT.

15. We will not for the future grant to any one that he may take aid of his own free tenants, unless to ransom his body, and to make his eldest son a knight, and onee to marry his eldest daughter; and for this there shall be only paid a reasonable aid.

16. No man shall be distrained to perform more service for a knight's fee, or other free tenement, than is due from thence.

17. Common pleas shall not follow our court, but shall be holden in some place certain.

18. Trials upon the Writs of Norel Disseisin, and of Mort d'ancestor, and of Darrein Presentment, shall not be taken but in their proper counties, and after this manner: We, or if we should be out of the realm, our chief justiciary, will send two justieiaries through every county four times a year, who, with four knights of each connty, chosen by the county, shall hold the said assizes in the county, on the day, and at the place appointed.

19. And if any matters cannot be determined on the day appointed for holding the assizes in each county, so many of the knights and freeholders as have been at the assizes aforesaid shall stay to decide them as is necessary, according as there is more or less business. 
also taken for the court, 20. A freeman shall not be amerced for a small at which the offence, but only according to the degree of the writs of Asoffence; and for a great crime according to the size are heinousness of it, saving to him his contenement. Taken." and after the same manner a merchant, saving to sizes, though him his merchandise And a villein shall be obsolete, him his merchandise. And a villein shall be were not anamerced after the same manner, saving to him his nulled until wainage, if he falls under our mercy; and none about 1823 . of the aforesaid amerciaments shall be assessed I.'s Charter,

but by the oath of honest men in the neighbour- Art. VIII. hood.

ment :

"That by which a person subsists and which is essential to his rank in life."

21. Earls and barons shall not be amerced Clauses 20but by their peers, and after the degree of the 21-22 were offence. intended to prevent tyrannical

22. No ecclesiastical person shall be amerced extortions. for his lay tenement, but according to the proportion of the others aforesaid, and not according to the value of his ecclesiastical benefice.

23. Neither a town nor any tenant shall be dis- Distrained = trained to make bridges or embankments, unless compelled. that anciently and of right they are bound to do it.

24. No sheriff, constable, coroner, or other our This article bailiffs, shall hold " Pleas of the Crown."

marks an era in history of criminal law by securing trial of all serious crimes before King's Justices.

25. All counties, hundreds, wapentakes, and trethings, shall stand at the old rents, without any increase, except in our demesne manors. 
Usually one third to the third to the heirs. See Henry I.'s Charter, Art. VII.

Henry I.'s Charter, VII. wife and one

26. If any one holding of us a lay fee die, and the sheriff, or our bailiffs, show our letters patent of summons for debt which the dead man did owe to us, it shall be lawful for the sheriff or our bailiff to attach and register the chattels of the dead, found upon his lay fee, to the amount of the debt, by the view of lawful men, so as nothing be removed until our whole clear debt be paid; and the rest shall be left to the executors to fulfil the testament of the dead; and if there be nothing due from him to us, all the chattels shall go to the use of the dead, saving to his wife and children their reasonable shares.

27. If any freeman shall die intestate, his chattels shall be distributed by the hands of his nearest relations and friends, by view of the Church, saring to every one his debts which the deceased owed to him.

28. No constable or bailiff of ours shall take corn or other chattels of any man unless he presently give him money for it, or hath respite of payment by the good-will of the seller.

29. No constable shall distrain any knight to give money for castle-guard, if he himself will do it in his person, or by another able man, in case he cannot do it througl any reasonable cause. And if we have carried or sent him into the army, he shall be free from such guard for the time he shall be in the army by our command.

30. No sheriff or bailiff of ours, or any other, shall take horses or carts of any freeman for carriage, without the assent of the said freeman.

31. Neither shall we nor our bailiffs take any man's timber for our castles or other uses, unless by the consent of the owner of the timber.

Confiscation of the lands of felons was not wholly abrogated antil 1870 .
32 . We will retain the lands of those convicted of felony only one year and a day, and then they shall be delivered to the lord of the fee. 
33. All kydells (wears) for the time to come To prevent shall be put down in the rivers of Thames and private Medway, and throughout all England, except upon appropriathe sea-coast.

tion to fish
in public
waters.
The purport
of this was to
prevent en-
closures of
common fish-
ing rights.
These wears
are now
called
"kettles" or
"kettle-
nets" in
Kent and
Cornwall.

34. The writ which is called prcecipe, for the fu- Protection of

ture, shall not be made out to any one, of any tene- local jurisment, whereby a freeman may lose his court.

35. There shall be one measure of wine and one of ale through our whole realm; and one measure of corn, that is to say, the London quarter; and one breadth of dyed clotb, and russets, and haberjeets, that is to say, two ells within the lists; and it shall be of weights as it is of measures.

36. Nothing From IIENCEForTI SHaLl BE GIVEN The basis of OR TAKEN FOR A WRIT OF INQUISITION OF LIFE OR security for LIMB, BUT IT SHALL BE GRANTED FREELY, AND NOT Liberty and DENIED.

37. If any do hold of us by fee-farm, or by socage, or by burgage, and he hold also lands of Socage $=$ any other by knight's service, we will not have the lands held custody of the heir or land, which is holden of inferior another man's fee by reason of that fee-farm, office in hussocage, or burgage; neither will we have the cus-bandry. torly of the fee-farm, or tody of the fee-farm, or socage, or burgage, unless delivery of knight's service was due to us out of the same fee- some small farm. We will not have the custody of an heir, nor weapon as a farm. We will not have the custody of an heir, nor token of the of any land which he holds of another by knight's king's ownservice, by reason of any petty serjeanty by which ership of 
he holds of us, by the service of paying a knife, an arrow, or the like.

38. No bailiff from henceforth shall put any man Law - i. e. to his law upon his own bare saying, without credihis oath.

See the Seal of the Supreme Court of Massachusetts.

This vital principle of personal liberty antedates Magna Charta, and was defined more clearly in "Habeas Corpus," and Trial by Jury. Called by Creasy the "crowning glories " of the Great Charter.

The trading class begins to show power at this time. ble witnesses to prove it.

39. NO FREEMAN SHALL BE TAKEN OR IMPRISONED, OR DISSEISED, OR OUTLAWED, OR BANISHED, OR ANY WAYS DESTROYED, NOR WILL WE PASS UPON IIIM, NOR WILL WE SEND UPON HIN, UNLESS BY THE LAWFUL JUDGMENT OF HIS PEERS, OR BY THE LAW OF TIIE LAND.

40. WE WILL SELL TO NO MAN, WE WILL NOT DENY or DELAy to aNy has, eituer JUstice or Right.

41. All merchants shall have safe and secure conduct, to go out of, and to come into England, and to stay there and to pass as well by land as by water, for buying and selling by the ancient and allowed customs, without any unjust tolls; except in time of war, or when they are of any nation at war with us. And if there be found any such in our land, in the beginning of the war, they shall be attached, without damage to their bodies or goods, until it be known unto us, or our chief justiciary, how our merchants be treated in the nation at war with us; and if ours be safe there, the others shall be safe in our dominions.

42. It shall be lawful, for the time to come, for any one to go out of our kingdom, and return safely and securely by land or by water, saving his alleSee Article 41. giance to us; unless in time of war, by some short space, for the common benefit of the realm, except prisoners and outlaws, according to the law of the land, and people in war with us, and merchants who shall be treated as is above mentioned.

43. If any man hold of any escheat as of the

The return of an estate to a lord, either on failure of honour of Wallingford, Nottingham, Boulogne, Lancaster, or of other escheats which be in our hands, and are baronies, and die, his heir shall give no other relief, and perform no other service to us than 
he would to the baron, if it were in the baron's tenant's hand; and we will hold it after the same manner as the baron held it.

44. 'Those men who dwell without the forest from Before henceforth shall not come before our justiciaries of Magna the forest, upon common summons, but such as are Charta, atimpleaded, or as sureties for any that are attached for something concerning the forest.

45. We will not make any justices, constables, sheriffs, or bailiffs, but of such as know the law of the realm and mean duly to observe it.

46. All barons who have founded abbeys, which they hold by charter from the kings of England, or by ancient tenure, shall have the keeping of them, when vacant, as they ought to have.

47. All forests that have been made forests in our time shall forthwith be disforested; and the same shall be done with the water-banks that have been fenced in by us in our time.

48. All evil customs concerning forests, warrens, foresters, and warreners, sheriffs and their officers, water-banks and their keepers, shall forthwith be inquired into in each county, by twelve sworn knights of the same county chosen by creditable persons of the same county; and within forty days after the said inquest be utterly abolished, so as never to be restored: so as we are first acquainted therewith, or our justiciary, if we should not be in England.

49. We will immediately give up all hostages and charters delivered unto us by our English subjects, as securities for their keeping the peace, and yielding us faithful service.

50 . We will entirely remove from their bailiwicks the relations of Gerard de Atheyes, so that for the future they shall have no bailiwick in England; we will also remove Engelard de Cygony, Andrew, Peter, and Gyon, from the Chancery; Gyon de Cygony, Geoffrey de Martyn, and his brothers; tendance at the Forest Court was compulsory.

\author{
(n)
}


Philip Mark, and his brothers, and his nephew, Geoffrey, and their whole retinue.

51. As soon as peace is restored, we will send out of the kingdom all foreign knights, cross-bowmen, and stipendiaries, who are come with horses and arms to the molestation of our people.

52. If any one has been dispossessed or deprived by us, without the lawful judgment of his peers, of his lands, castles, liberties, or right, we will forthwith restore them to him; and if any dispute arise upon this head, let the matter be decided by the five-and-twenty barons hereafter mentioned, for the preservation of the peace. And for all those things of which any person has, without the lawful judgment of his peers, been dispossessed or deprived, either by our father King Henry, or our brother King Richard, and which we have in our hands, or are possessed by others, and we are bound to warrant and make good, we shall have a respite till the term usually allowed the crusader's ; excepting those things about which there is a plea depending, or whereof an inquest hath been made, by our order before we undertook the crusade; but as soon as we return from our expedition, or if perchance we tarry at home and do not make our expedition, we will immediately cause full justice to be administered therein.

53. The same respite we shall have, and in the same manner, about administering justice, disafforesting or letting continue the forests, which Henry our father, and our brother Richard, have afforested; and the same concerning the wardship of the lands which are in another's fee, but the wardship of which we have hitherto had, by reason of a fee held of us by knight's service; and for the abbeys founded in other fee than our own, in which the lord of the fee says he has a right; and when we return from our expedition, or if we tarry at home, and do not make our expedition, we will immediately do full justice to all the complainants in this behalf. 
54. No man shall be taken or imprisoned upon the appeal of a woman, for the death of any other than her husband.

55. All unjust and illegal fines marle by us, and all amerciaments imposed unjustly and contrary to the law of the land, shall be entirely given up, or else be left to the decision of the five-and-twenty barons hereafter mentioned for the preservation of the peace, or of the major part of them, together with the aforesaid Stephen, Archbishop of Canterbury, if he can be present, and others whom he shall think fit to invite; and if he cannot be present, the business shall notwithstanding go on without him; but so that if one or more of the aforesaid five-and-twenty barons be plaintiffs in the same cause, they shall be set aside as to what concerns this partieular affair, and others be chosen in their room, out of the said five-and-twenty, and sworn by the rest to decide the matter.

56. If we have disseised or dispossessed the Welsh of any lands, liberties, or other things, without the legal judgment of their peers, either in England or in Wales, they shall be immediately restored to them; and if any dispute arise upon this head, the matter shall be determined in the Marches by the judgment of their peers ; for tenements in England according to the law of England, for tenements in Wales according to the law of Wales, for tenements of the Marches according to the law of the Marches: the same shall the Welsh do to us and our subjects.

57. As for all those things of which a Welshman hath, without the lawful judgment of his peers, been disseised or deprived of by King Henry our father, or our brother King Richard, and which we either have in our hands or others are possessed of, and we are obliged to warrant it, we shall have a respite till the time generally allowed the erusaders; excepting those things about which a suit is de- 
pending, or whereof an inquest has been made by our order, before we indertook the crusarle: but when we return, or if we stay at home without performing our expedition, we will immediately clo them full justice, according to the laws of the Welsh and of the parts before mentioned.

58 . We will without delay dismiss the son of Llewellin, and all the Welsh hostages, and release them from the engagements they have entered into with us for the preservation of the peace.

59. We will treat with Alexander, King of Scots, concerning the restoring his sisters and hostages, and his right and liberties, in the same form and manner as we shall do to the rest of our barons of England; unless by the charters which we have from his father, William, late King of Scots, it ought to be otherwise; and this shall be left to the determination of his peers in our court.

There was a close union between baronage and citizens from 1213 to 1217 .

The immediate abuses were easily swept away, the hostages restored to their homes, the foreigners banished from the country. But towards any person, or shall have broken through

60. All the aforesaid customs and liberties, which we have granted to be holden in our kingdom, as much as it belongs to us, all people of our kingdom, as well clergy as laity, shall observe, as far as they are concerned, towards their dependents.

61. And whereas, for the honour of God and the amendment of our kingdom, and for the better quieting the discord that has arisen between us and our barons, we have granted all these things aforesaid; willing to rencler them firm and lasting, we do give and grant our subjects the underwritten security, namely, that the barons may choose fiveand-twenty barons of the kingdom, whom they think convenient; who shall take eare, with all their might, to hold and observe, and cause to be observed, the peace and liberties we have granted them, and by this our present Charter confirmed in this manner; that is to say, that if we, our justiciary, our bailiffs, or any of our officers, shall in any circumstance have failed in the performance of them 
any of these articles of peace and seeurity, and the it was less offence be notified to four barons chosen out of the easy to profive-and-twenty before mentioned, the said four for the conbarons shall repair to us, or our justiciary, if we trol of a King are out of the realm, and, laying open the grievance, whom no shall petition to have it redressed without delay : and trust. if it be not redressed by us, or if we should chance to be out of the realm, if it should not be redressed by our justiciary within forty days, reckoning from the time it has been notified to us, or to onr justiciary (if we should be out of the realm), the four barons aforesaid shall lay the cause before the rest of the five-and-twenty barons; and the said fiveand-twenty barons, together with the community of the whole kingdom, shall distrain and distress us in all the ways in which they shall be able, by seizing our castles, lands, possessions, and in any other manner they can, till the grievance is redressed, aecording to their pleasure; saving harmless our own person, and the persons of our Queen and children; and when it is redressed, they shall behave to us as before. And any person whatsoever in the kingdom may swear that he will obey the orders of the five-and-twenty barons aforesaid in the execution of the premises, and will distress us, jointly with them, to the utmost of his power; and we give public and free liberty to any one that shall please to swear to this, and never will hinder any person from taking the same oath.

62. As for all those of oul subjects who will not, of their own accord, swear to join the five-andtwenty barons in distraining and distressing us, we will issue orders to make them take the same oath as aforesaid. And if any one of the five-and-twenty barons dies, or goes ont of the kingdom, or is hindererl any other way from carrying the things aforesaid into execution, the rest of the saicl five-andtwenty barons may choose another in his room, at their discretion, who shall be sworn in like manner as the 
rest. In all things that are committed to the execution of these five-and-twenty barons, if, when they are all assembled together, they should happen to disagree about any matter, and some of them, when summoned, will not or cannot come, whatever is agreed upon, or enjoined, by the major part of those that are present shall be reputed as firm and valid as if all the five-and-twenty had given their consent; and the aforesaid five-and-twenty shall swear that all the premises they shall faithfully observe, and cause with all their power to be observed. And we will procure nothing from any one, by ourselves nor by another, whereby any of these concessions and liberties may be revoked or lessened; and if any such thing shall have been obtained, let it be null and void; neither will we ever make use of it either by ourselves or any other. And all the ill-will, indignations, and rancours that have arisen between us and our subjects, of the clergy and laity, from the first breaking out of the dissensions between us, we do fully remit and forgive : moreover, all trespasses occasioned by the said dissensions, from Easter in the sixteenth year of our reign till the restoration of peace and tranquillity, we hereby entirely remit to all, both clergy and laity, and as far as in us lies do fully forgive. We have, moreover, caused to be made for them the letters patent testimonial of Stephen, Lord Archbishop of Canterbury, Henry, Lord Archbishop of Dublin, and the bishops aforesaid, as also of Master Pandulph, for the security and concessions aforesaid.

63. Wherefore we will and firmly enjoin, that the Church of England be free, and that all men in our kingdom have and hold all the aforesaid liberties, rights, and concessions, truly and peaceably, freely and quietly, fully and wholly to themselves and their heirs, of us and our heirs, in all things and places, for ever, as is aforesaid. It is also sworn, as well on our part as on the part of the barons, that all 
the things aforesaid shall be observed in good faith, and without evil subtilty. Given under our hand, in the presence of the witnesses above named, and many others, in the meadow called Runingmede, between Windsor and Staines, the 15th day of June, in the 17 th year of our reign.

\section{CONTEMPORARY EXPOSITION}

ROGER OF WENDOVER (1235)

A. D. 1215, which was the seventeenth year of the reign of King John; he held his court at Winchester at Christmas for one day, after which he hurried to London, and took up his abode at the New Temple, and at that place the abovementioned nobles came to him in gay military array, and demanded the confirmation of the liberties and laws of King Edward (the Confessor), with other liberties granted to them and to the kingdom and church of England, as were contained in the charter, and above mentioned laws of Henry the First; they also asserted that, at the time of his absolution at Winchester, he had promised to restore those laws and ancient liberties, and was bound by his own oath to observe them. The king, hearing the bold tone of the barons in making this demand, much feared an attack from them, as he saw that they were prepared to battle; he, however, made answer that their demands were a matter of importance and difficulty, and he therefore asked a truce till the end of Easter, that he might, after due deliberation, be able to satisfy them as well as the dignity of his crown. . . .

The barons then delivered to the messengers a paper, containing in great measure the laws and ancient customs of the kingdom, and declared that, nnless the king immediately granted them and confirmed them under his own seal, they would, by taking possession of his fortresses, force him to give them sufficient satisfaction as to their before-named demands. The archbishop with his fellow-messengers then carried the paper to the king, and read to him the hearls of the paper one by one throughont. 'The king, when he heard the purport of these heads, derisively said, with the greatest indignation, "Why, 
amongst these unjust demands, did not the barons ask for my kingdom also? Their demands are vain and visionary, and are unsupported by any plea of reason whatever." And at length he angrily declared with an oath, that he would never grant them such liberties as would render him their slave. The principal of these laws and liberties, which the nobles required to be confirmed to them, are partly described above in the charter of King Henry, and partly are extracted from the old laws of King Edward, as the following history will show in due time. . . .

King John, when he saw that he was deserted by almost all, so that out of his regal superabundance of followers he scarcely retained seven knights, was much alarmed lest the barons would attack his castles and reduce them without difficulty, as they would find no obstacle to their doing so; and he deceitfully pretended to make peace for a time with the aforesaid barons, and sent William Marshal, earl of Pembroke, with other trustworthy messengers, to them, and told them that, for the sake of peace, and for the exaltation and honour of the kingdom, he would willingly grant them the laws and liberties they required; he also sent word to the barons by these same messengers, to appoint a fitting day and place to meet and carry all these matters into effect. The king's messengers then came in all haste to London, and without deceit reported to the barons all that had been deceitfully imposed on them; they in their great joy appointed the 15 th of June for the king to meet them, at a field lying between Staines and Windsor. Accordingly, at the time and place pre-agreed on, the king and nobles came to the appointed conference, and when each party had stationed themselves apart from the other, they began a long discussion about terms of peace and the aforesaid liberties. . . .

At length, after various points on both sides had been discussed, King John, seeing that he was inferior in strength to the barons, without raising any difficnlty, granted the underwritten laws and liberties, and confirmed them by his charter as follows.

Roger Wendover, Flowers of History (Giles's translation, 1849). II. 304. 


\section{CRITICAL COMMENT}

COKE (1628).

This parliamentary charter hath divers appellations in law. It is called Magna Charta, not for the length or largeness of it ... but it is called the Great Charter, in respect of the great weightiness and wcighty greatness of the matter contained in it in few words, being the fountain of all fundamental law ; and therefore it may truly be said of it, that it is magnum in parvo.

Sir Edward Coke, First Institute of the Laws of England. I. 22.

BURKE (1774)

Magna Charta, if it did not give us originally the House of Commons, gave us at least a House of Commons of weight and consequence.

Edmund Burke, Works. II. 53.

\section{HALLAM (1818)}

As this was the first effort towards a legal government, so is it beyond comparison the most important event in our history, except that revolution without which its benefits would rapidly have been annihilated. . . . It (the Great Charter) is still the keystone of English liberty. All that las since been obtained is little more than as confirmation or commentary. . . . The essential clauses of Magna Charta are those which protect the personal liberty and property of all freemen by giving security from arbitrary imprisonment and arbitrary spoliation. ... From this era a new soul was infused into the people of England. Her liberties at the best long in abeyance, became a tangible possession, and those indefinite aspirations for the laws of Edward the Confessor, were changed into a steady regard for the Great Charter.

IIenry Hallam, Europe during the Middle Ages. Chap. VIII. 341-342.

\section{PALGRAVE (1832)}

By far the greatest portions of the written or statute laws of England consist of the declaration, the reassertion, repetition, 
or the re-enactment of some older law or laws, either customary or written, with addition or modifications. The new building has been raised upon the old ground-work: the institutions of one age have always been modelled and formed from those of the preceding, and their lineal descent has never been interrupted or disturbed.

Sir James Palgrave, English Commonwealth. I. 6.

MACKINTOSH (1832)

Whoever in any future age or yet unborn nation may admire the felicity of the expedient which converted the power of taxation into the shield of liberty, by which discretionary and secret imprisonment was rendered impracticable, and portions of the people were trained to exercise a larger share of judicial power than ever was allotted to them in any other civilized State, in such a manner as to secure, instead of endangering, public tranquillity; whoever exults at the spectacle of enlightened and independent assemblies, whicl, under the eye of a well informed nation, discuss and determine the laws and policy likely to make communities great and happy; whoever is capable of comprehending all the effects of such institutions with all their possible improvements upon the mind and genius of a people, - is sacredly bound to speak with reverential gratitude of the authors of the Great Charter. To have produced it, to have preserved it, to have matured it, constitute the immortal claim of England upon the esteem of mankind. Her Bacons and Shakespeares, her Miltons and Newtons, with all the truth which they have revealed, and all the generous virtue which they have inspired, are of inferior value when compared with the subjection of men and their rulers to the principles of justice, if, indeed, it be not more true that these mighty spirits could not have been formed except under equal laws, nor roused to full activity without the influence of that spirit which the Great Charter breathed over their forefathers.

Sir James Mackintosir, History of England. I. 221. 
STUBBS (1873)

The Great Charter closes one epoch and begins another. On the one hand it is the united act of a nation that has been learning union; the enunciation of rights and liberties, the needs and uses of which have been taught by long years of training and by a short but bitter struggle: on the other hand it is the watehword of a new political party, the starting-point of a new contest.

Winliam Stubis, Constitutional History of England. II. 1.

\section{J. R. GREEN (1874)}

An island in the Thames between Staines and Windsor had been chosen as the place of conference: the King encamped on one bank, while the barons covered the marshy flat, still known by the name of Runnymede, on the other. Their delegates met in the island between them, but the negotiations were a mere cloak to cover John's purpose of unconditional submission. The Great Charter was discussed, agreed to, and signed in a single day. One copy of it still remains in the British Musenm, injured by age and fire, but with the royal seal still hanging from the brown, shrivelled parchment. It is impossible to gaze without reverence on the earliest monument of English freedom which we ean see with our own eyes and touch with our own hands, the great Charter to which from age to age patriots have looked back as the basis of English liberty. But in itself the Charter was no novelty, nor did it claim to establish any new constitutional principles. 'The Charter of Henry the First formed the basis of the whole, and the additions to it are for the most part formal recognitions of the judicial and administrative changes introduced by Henry the Second. But the vague expressions of the older charters were now exchanged for precise and elaborate provisions. The bonds of unwritten custom which the older grants did little more than recognize had proved too weak to hold the Angevins; and the baronage now threw them aside for the restraints of written law. It is in this way that the Great Charter marks the transition from the age of traditional rights, preserved in the nation's memory and oflicially declared by the Primate, to the age of written 
legislation, of Parliaments and Statutes, which was soon to come. The Church had shown its power of self-defence in the struggle over the interdict, and the clause which recognized its rights alone retained the older and general form. But all vagueness ceases when the Charter passes on to deal with the rights of Englishmen at large, their right to justice, to security of person and property, to good government. "No freeman," ran the memorable article that lies at the base of our whole judicial system, " shall be seized or imprisoned, or dispossessed, or outlawed, or in any way brought to ruin: we will not go against any man nor send against him, save by legal judgment of his peers or by the law of the land." "To no man will we sell," runs another, "or deny, or delay, right or justice." The great reforms of the past reigns were now formally recognized; judges of assize were to hold their circuits four times in the year, and the King's Court was no longer to follow the King in his wanderings over the realm, but to sit in a fixed place. But the denial of justice under John was a small danger compared with the lawless exactions both of himself and his predecessor. Richard had increased the amount of the scutage which Henry II. had introduced, and applied it to raise funds for his ransom. He had restored the Danegeld, or land tax, so often abolished, under the new name of "carucage," had scized the wool of the Cistercians and the plate of the churches, and rated moveables as well as land. John had again raised the rate of scutage, and imposed aids, fines, and ransoms at his pleasure without counsel of the baronage. The Great Charter met this abuse by the provision on which our constitutional system rests. With the exception of the three customary feudal aids which still remained to the Crown, " no scutage or aid shall be imposed in our realm sare by the Common Council of the realm;" and to this Great Council it was provided that prelates and the greater barons should be summoned by special writ, and all tenants in chief through the sheriffs and bailiffs, at least forty days before. . . . But it was less easy to provide means for the control of a King whom no man could trust, and a council of twenty-five barons was chosen from the general body of their order to enforce on John the observance of the Charter, with the right of declaring war on the King should its 
provisions be infringed. Finally, the Charter was published throughout the whole eountry, and sworn to at every hundredmote and town mote by order from the King.

J. R. Green, Short History of the English People. 128-130.

BAGEHOT (1872)

Many most important enactments of that period (and the fact is most characteristic) are declaratory acts. They do not profess to enjoin by inherent authority what the law shall in future be, but to state and mark what the law is; they are declarations of immemorial eustom, not preeepts of new duties. Even in the "Great Charter" the notion of new enactments was secondary, it was a great mixture of old and new; it was a sort of compact defining what was doubtful in floating custom.

Walter Bagehot, English Constitution. 280.

TASWELL-LANGMEAD (1879)

Three great political documents, in the nature of fundamental compacts between the Crown and the Nation, stand out as prominent landmarks in English Constitutional history. Magna Charta, the Petition of Right, and the Bill of Rights constitute, in the words of Lord Chatham, "the Bible of the English Constitution." In eacl of these documents whether it be of the 13 th or of the 17 th eentury is observable the common characteristic of professing to introduce nothing new. Each professed to assert rights and liberties which were already old, and sought to redress grievanees which were for the most part themselves innovations upon the aneient liberties of the people. In its practical combination of conservative instinets with liberal aspirations, in its power of progressive development and self-arlaptation to the changing political and social wants of each successive generation, have always lain the peculiar excellence and at the same time the surest safeguard, of our Constitution.

The Great Charter of Liberties was the outcome of a movement of all the freemen of the realm, led by their natural leaders, the barons. Far from being a 'mere piece of class legislation,' extorted by the barons alone for their own special interests, it 
is in itself a noble and remarkable proof of the sympathy and union then existing between the aristocracy and all classes of the commonalty.

J. P. Taswell-Langmead, English Constitutional History. 85.

RUDOLF VON GNEIST (1889)

This charter of liberties differed from those prevalent on the continent, especially in the fact that the Prelates and vassals do not think of themselves alone, but also extend the necessary securities to the classes below them. . . Magna Charta was a pledge of reconciliation between all classes. Its existence and ratification maintained, for centuries, the notion of fundamental rights as applicable to all classes, in the consciousness that no liberties could be upheld by the superior classes for any length of time, without guarantees of personal liberty for the humbler also.

Rudolf von Gneist, History of the English Parliament, translated by A. H. Keane. 29-103.

\section{POLLOCK AND MAITLAND (1895)}

Every one of its brief sentences is aimed at some different object and is full of future law.

Pollock ANd Mattland, History of English Law. I. 150.

\section{GARDINER (1895)}

It was a good security if it could be maintained. . . . So little was John trusted that it was thought necessary . . . to establish a body of twenty-five, - twenty-four barons and the Mayor of London, - which was to guard against any attempt of the king to break his word. . . . In other words, there was to be a permanent organization for making war upon the king.

Gardiner, Student's History of England. 183.

RANSOME (1895)

One of the best features of the charter was the way in which every right granted to a haron was carefully extended to include the case of the simple freeman. . . These provisions and many 
others which concerned every class of the population form the substance of the Great Charter, which has ever since been regarded by Englishmen as the foundation of their liberties. In later times it took the position in popular esteem which had hitherto been held by the "laws of Henry I.," or the "laws of King Edward," and has been confirmed over and over again.

Cyril Ransome, Advanced History of England. 176-177. 


\section{Chapter III}

\section{THE SUMMONS TO PARLIAMENT (1295)}

\section{SUGGESTIONS}

THE importance of the "Summons" is chiefly prospective. It takes a place among documents more famous because it is typical of a large class of constitutioual services.

This summons, together with similar writs, was issued by order of the Crown. The king had found himself early in 1295 in very difficult circumstances. In June he issued writs of summons to the members of Parliament to meet at Westminster in August; this meeting lasted but two days, and as no representative of the Commons was summoned to this assembly, it is more properly styled a session of a Great Council. No attempt was made in it to raise money, but it was probably arranged that a grant should be asked for in the next session. With this in view, writs were issued on the 30th of September to the Ecclesiastical representatives. On the 1st of October, the writs were issued to the baronage. On the 3rd of October the writs to the sheriffs are dated; and by these each sheriff is directed to return two knights elected by the counties, and two citizens or burghers for each city or borough within his shire.

By such writs of summons a perfect representation of the three estates was secured, and a parliament constituted, on the model of which every succeeding assembly bearing that name was formed.

One may well pause at this point to look back upon the Witenagemot of the Teutonic system of government and look forward to the assembly body of the Congress of the United States.

For Outlines and Material, see Appendix A.

\section{DOCUMENT}

\section{Summons to Parliament (Oct. 3rd, 1295)}

Report on The King to the Sheriff of Northamptonshire: the Dignity Whereas, in order to make provision of remedies
of a Peer, of a Peer,
App. i., p. 66, against the dangers which at this time menace the translated realm, we desire to take counsel with the earls, 
barons, and other noblemen of our kingdom, and by Henry A. for that reason have commanded them to meet us on the Sunday next after the feast of Saint Martin in the winter next ensuing, at Westminster, for the discussing, ordaining and doing of whatsoever may be best for the obviating of such dangers,

We do hereby firmly command and enjoin you I. Art. i. that there be chosen without delay from the afore- Note Magna said county two knights, and from every city of Charta, Art. that county two citizens, from every borough two burgesses, all men of superior discretion and ability in affairs, and that you have them come to us at the day and place aforesaid;

In order that said knights shall have, in behalf of themselves and the body of the comnty aforesaid, full and sufficient power, and that said citizens and burgesses shall have, in behalf of themselves and the body of the cities and boroughls aforesaid both Note the inseparately and collectively, full and sufficient power, crease of for doing what shall then be ordained by the com- power in mon counsel in the premises; so, that the business Conmons. aforesaid shall in no wise remain unaccomplished for want of such power.

And have you there the names of the knights, eitizens, and burgesses, and this writ.

Witness the King at Canterbury the third day of October.

\section{CONTEMPORARY EXPOSITION}

THOMAS CROMWELL (1523)

Maister Creke, as hertelye as I can I commende me and in the same wise thanke you (for your) gentill and louyng letteres to me at sundrye tymys sent, and when as I accordinglye haue not in lykewise remembrid and rescribid it hath been For that I haue not hade anything to wryt of to your aduauncement. Whom I assure you yf it were in my lyttyl power I coulde be well contentyd to preferre as ferre as any one unan lyuyng. But at this present $I$ being at sum layser entending to re- 
membre and also remanerate the olde acquayntannces and to renew our not forgoten sundrye communycacions supposing ye desyre to know the newes curraunt in thes partyes for it is said that newes refresshith the spy(rit) of lyfe, wherfor ye shall onderstonde that bw long tyme I amongst other haue Indured a parlyament which contenwid by the space of xvij hole wekks wher we communyd of warre pease stryffe contencyon debatte murmure grudge Riches pouerte penwrre trowth falshode Justyce equyte discayte opprescyon Magnanymte act yuyte force attem praunce Treason murder Felonye consyli . . . and also how a commune welth myght be edifyed and a(lso) contenwid within our Realme. Howbeyt, in conclusyon, we have d(one) as our predecessors haue been wont to doo, that ys to say, as well as we myght and lefte wher we begann. Ye shall also onderstond the Duke of Suthfolke Furnysshyd with a gret armye goyth ouer in all goodbye haste (whit)her I know not, when I know I shall aduertyse yow. Whe haue in our parlyament grantyd onto the Kinges highness a ryght large subsyde, the lyke wherof was neur grantyd in this realme. All your frendes to my knowlage be in good helth and specially they that ye wott of : ye know what I meaoe. I thinke it best to wryt in parables becaus(e) $I$ am in doubt. Maister Vawhan Fareth well and so doth Maister Munkeaste(r). Maister Woodall is merye withowt a wyffe and commendyth hym to you: and so ys also Nycholas Longmede which hath payd William Wilfforde. And thus as well $\mathrm{f}$ (are) ye as I woolde myself at London the xvij daye of August by. your Frende to all his possible power.

\section{Thomas Crumwell.}

Add: To his (esp)ecial and entyrelye belouyd frende John Creke be this youyn Bylbowe in Biscaye.

Roger B. Merriman, Life of Thomas Cromwell (MS.), in the College Office of Harvard University.

\section{the coppy of the Kynges letter}

In my herty wyse I recomendeme unto you these shalbe forasmoche as the Kynges plesur and comandement ys that Robert Derknall and John Bryges schulbe electe and chosyn Citezin or burgesses for that cite by reson wherof my lorde chaun- 
celer and I by owyr letteres written onto you aduertysed you therof and ye the same little or nothynge regardynge but ratther contemny haue closen othyr at your owne wylles and comandement in that behalfe wherat the kynges highnes dothe not a lytell marvell wherefore in advoydyng of ferther dysplesur, that mygte therby ensue $\mathrm{I}$ require you on the kynges behalfe that notwythstondynge seyd eleccion ye procede to a new and electe thosse other, accordynge to the tenure of the former letteres to you dyrectyd for that purpose without faylyng so to do as the kynges truste and expecion is in you and as ye entende to avoide hys highness displesur at your parell and yf any persone wyll obstynately gaynsay the same I require you to aduertise me therof that I maye ordre hym as the kynges plesur shalbe in that case to commande thus fare ye well at the rolles the viii $\dagger$ day of May.

Your louynge frende,

Thomas Cromwell.

Add: To my ryzth louynge frendes the mayr sheeyffe and cominaltie of the Cite of Cannterbury and to euery of them.

[This official letter was written by Thomas Cromwell to the "Magistrates" (i. e., Town Comcil) of Canterbury, May 18, 1536. It is in the MS. Life of Cromwell, cited above.]

\section{CRITICAL COMMENT}

\section{HALLAM (1818)}

To grant money was therefore the main object of their meet ing; and if the exigencies of the administration could have been relieved without subsidies, the citizens and burgesses might still have sat at home, and obeyed the laws which a council of prelates and barons enacted for their government. But it is a difficult question, whether the king and the peers designed to make room for them, as it were, in legislation; and whether the power of the purse drew after it immediately, or only by degrees, those indispensable rights of consenting to laws which they now possess.

Henry Haldau, Middle Ages. 370.

† Altered to this from "xx." 


\section{STUBBS (1873)}

The design, as interpreted by the result, was the creation of a national parliament, composed of the three estates, organized on the principle of concentrating local agency and machinery in such a manner as to produce unity of national action, and thus to strengthen the hand of the king, who personified the nation. This design was perfected in 1295 . It was not the result of compulsion, but the consummation of a growing policy. Edward did not call his parliament . . . on the spur of a momentary necessity, or as a new machinery invented for the occasion and to be thrown aside when the occasion was over, but as a perfected organization, the growth of which he had for twenty years been doing his best to guide.

Wrlliam StubBs, Constitutional History of England. II. 305.

TASWELL-LANGMEAD (1879)

From 1265 to 1295 was a transitionary period: and it is only from the latter year that we can date the regular and complete establishment of a perfect representation of the Three Estates in Parliament. . . . The position of the kingdom was still critical, and Edward seems to have felt that he required to be backed up by the whole nation, supporting him as well by their common counsel and approval as by a general and adequate grant of an aid. He accordingly, on the 30th of September, summoned a parliament to meet at Westminster in the November following, so constituted as to represent and have the power to tax the whole nation.

T. P. Taswell-Langmead, English Constitutional History. 200-207.

\section{J. K. HOSMER (1890)}

It was in the autumn of 1295 that he (Edward I.) performed his most memorable act, the last formal step which established fully the representation of the Commons. . . . The forward steps which the nation took, sometimes, to be sure, in spite of him, but sometimes under his guidance, were most momentous. The Great Charter was again and again confirmed, until it became as fixed as the hills, in the national life. . . . In 1297, it was clearly established that there can be no taxation without 
representation, - a principle upon which, five hundred years later, stood the Americans of '76. . . Parliament, too, stood forth, a well defined and organized expositor of the national will.

J. K. Hosmer, Anglo-Saxon Freedom. 60,61.

BOUTMY (1891)

In 1295 , the custom of summoning two knights from each county had become fixed. .. . From that time forward no Parliament was formally constituted without a summons addressed to eacl of these two classes. During the same period another element had been admitted to the assembly. The principal towns, those especially which possessed charters, had been convoked in 1265 by Simon de Montfort; thirty years later a royal ordinance called upon them to send two inhabitants, citizens, or burgesses, as representatives, and after that year they received regularly a summons to Parliament. The year 1295 is therefore a date of capital importance. The beginning of the fourteenth century found Parliament consisting of all the essentials of a truly national assembly, and representing even more completely than at the present day (for certain elements have been lost by exclusion or disuse) the various components of the English nation.

Emile Boutmy, English Constitution. 65, 66.

FREEMAN (1892)

One may certainly doubt whether Edward, when he summoned a baron to Parliament, meant positively to pledge himself to summon that baron's heirs for ever and ever or even necessarily to summon the baron himself to every future parliament. The facts are the other way: the summons still for a while remains irregular. But the perpetual summons, the hereditary summons, gradually became the rule, and that rule may in a certain sense be said to date from 1295, the year from which so many things parliamentary date.

Edwd. Freeman, House of Lords, in Fourth Series of Historical Essays. 454.

RANSOME (1895)

In this assembly were represented each of what were beginning to be known as the three estates of the realm, the 
clergy, the nobility, and the commonalty.... Thirty years had elapsed since the citizens and burgesses had been called to Simon de Moutfort's convention in 1265. Since then it had been no uncommon thing to summon knights and burgesses to parliament, but the exact constitution of the assembly was by no means definitely settled. . . . This is, therefore, the first real parliament in which they had ever taken part. . . . The meeting of the Model Parliament of 1295 was a memorable day for England, and marks the beginning of a new era of parliamentary government.

Cyril Ransome, Advanced History of England. 219, 220.

\section{S. R. GARDINER (1895)}

Edward, attacked on two sides, threw himself for support on the English nation. Towards the end of 1295 he summoned a Parliament which was in most respects the model for all succeeding Parliaments. It was attended not only by bishops, abbots, earls, and barons, by two knights from every shire, and tivo burgesses from every borough, but also by representatives of the chapters of cathedrals and of the parochial clergy.

S. R. Gardiner, Student's History of England. 218.

\section{G. B. ADAMS (1900)}

If the burgesses were certain to be admitted into the older institution there was nothing in that fact or in any other circumstance of the time that determined the form and character which the new institution was to assume, and this was a question of vital importance for the future. Upon it depended the existence of the constitution quite as much as upon the survival and the broadened significance of the ideas of the Magna Carta. In this particular the decisive period, the danger period, was that which extended from 1254 to 1295 . We have a right, I think, to make 1295 the date of the beginning of Parliament. To be sure there was nothing whatever about the parliament of 1295 considered by itself alone which indicated that it was to be any more truly the model parliament than any one of the different experimental forms of the preceding forty years. It possessed more of the features of the curia regis than of a later parliament; the whole question of 
estates and of organization was still unsettled; the struggle for the supremacy of the new parliament over the survivals of the old curia regis had still to be fought out in the following century, but as a historical fact the parliament of 1295 was the model parliament. The age of experimenting was over. In all the creative fundamental principles, both of constitution and of powers, Parliament was in existence as a different thing institutionally from the old curia regis. The later development was a perfection of details, an application of established principles to a constantly eularging range of cases, not a work of new creation.

Geo. B. Adams, Critical Periods of English constitutional History, in American Historical Review (July, 1900). 656. 


\section{Chapter IV \\ CONFIRMATIO CHARTARUM (1297)}

\section{SUGGESTIONS}

Is events which led to this Charter we trace two distinct forces, namely, clerical and baronial defiance, which, timed by an extraordinary coincident, culminated together. The treasury was utterly drained. King Edward, from sheer want, was driven to tyrannous extortion, when planning his second attack on France with the aid of Flanders. The Church and Baronage alike defied him. Bohun, Earl of Hereford, and Bigod, Earl of Norfolk, headed the opposition. Edward found himself powerless to move, and in a burst of feeling owned that he had taken their substance without due warrant of law. Still in want of money, he appealed to the barons, but they in turn demanded redress of grievances and the confirmation of Magna Charta. In August, Edward proceeded to Ghent, leaving his son, Edward, Prince of Wales, as Regent. As soon as the King had departed, the Earls seized the opportunity to press their demands. Entering the Exchequer, they peremptorily forbade the Barons there to levy the aid, the grant of which they asserted had been illegally obtained, until the charters had been confirmed. Supported by a large military following, and backed up by the citizens of London, they were masters of the situation, and the young Prince and his Conncil found it necessary to yield. The Confirmatio Chartarum, which, althongh a statute, is drawn up in the form of a charter, was passed on the 10th of October, 1297, in a Parliament at which knights of the shire attended as representatives of the Commons, as well as the lay and clerical Baronage. It was immediately sent over to King Edward at Ghent, and there confirmed by him on the 5th of November following.

These articles were drawn up in French. Another set, in Latin, differing in one or two important points, is known as the statute "de Tallagio non concedendo." This is referred to in the preamble of the Petition of Right, and is recognized as a statute by a decision of the Judges in 1637

In Confirmatio Chartarum, as in Magna Charta, we find a culmination of influences bringing about a document which has a vital place in the organization of all future government. Such charters are "the rallying-point of the oppressed and the offended," and no student of American liberty can appreciate intelligently the struggle from $\mathbf{1 7 6 5}$ to 1776 without an insight into the historic beginnings of "Taxation without representation."

For Outlines and Material, see Appendix A. 


\section{DOCUMENT}

"Confirmatio Chartarum" of Edward I. (1297)

I. Edward, by the grace of God, King of Eng- The Statutes land, Lord of Ireland, and Duke Guyan, to all those of the Realm, that these present letters shall hear or see, greeting. i. 123, 124, Know ye that we to the honour of God and of holy by William Church, and to the profit of our realm, have granted Stubbs, for us and our heirs, that the Charter of Liberties ters, 486, and the Charter of the Forest, which were made by common assent of all the realm, in the time of King Henry our father, shall be kept in every point without breach. And we will that the same charters shall be sent under our seal as well to our justices of The gist of the forest as to others, and to all sheriffs of shires, Magna and to all our other officers, and to all our cities of the Charthroughout the realm, together with our writs in the ter of the which it shall be contained, that they cause the porest apforesaid charters to be published, and to declare to the people that we have confirmed them in all points, and that our justices, sheriffs, mayors, and other ministers which under us have the laws of our land to guide, shall allow the said charters pleaded before them in judgment in all their points; that is to wit, the Great Charter as the common law, and the Charter of the Forest according to the Assize of the Forest, for the wealth of our realm.

II. And we will that if any judgment be given from henceforth, contrary to the points of the charters aforesaid, by the justices or by any other our The remedy ministers that hold plea before them against the against arbipoints of the charters, it shall be undone and holden ment lay in for nought.

III. And we will that the same charters shall be the law of Art. ii. sent under our seal to cathedral churches throughout our realm, there to remain, and shall be read before the people two times by the year.

Arts. iii. and iv. limit the

IV. And that all archbishops and bishops shall authority of pronounce the sentence of great excommunication the Church. 
against all those that by word, deed, or counsel do contrary to the foresaid charters, or that in any point break or undo them. And that the said curses be twice a year denounced and published by the prelates aforesaid. And if the prelates or any of them be remiss in the denunciation of the said sentences, the Archbishops of Canterbury and York for the time being, as is fitting, shall compel and distrein them to make that denunciation in form aforesaid.

V. . And for so much as divers people of our realm are in fear that the aids and tasks which they have given to us beforetime towards our wars and other business, of their own grant and goodwill, howsoever they were made, might turn to a bondage to them and their heirs, because they might be at another time found in the rolls, and so likewise the prises taken throughout the realm by our ministers;

Articles v., vi., and vii. contain the essence of the principle, "No taxation without representation."

we have granted for us and our heirs, that we shall not draw such aids, tasks, nor prises into a custom, for anything that hath been done heretofore, or that may be found by roll or in any other manner.

VI. Moreover we have granted for us and our heirs, as well to archbishops, bishops, abbots, priors, and other folk of holy Church, as also to earls, barons, and to all the commonalty of the land, that for no business from henceforth will we take such manner of aids, tasks, nor prises, but by the common consent of the realm, and for the common profit thereof, saving the ancient aids and prises due and accustomed.

VII. And for so much as the more part of the commonalty of the realm find themselves sore grieved with the maletote of wools, that is to wit, a toll of forty shillings for every sack of wool, and have made petition to us to release the same; we, at their reBeginning of quests, have clearly released it, and have granted a system by for us and our heirs that we shall not take such thing in foreign nor any other without their common assent and good 
will; saving to us and our heirs the custom of wools, trade were skins, and leather granted before by the commonalty made subject aforesaid. In witness of which things we have ment. caused these our letters to be made patents. Witness Edward our son at London, the 10th day of October, the five and twentieth year of our reign.

And be it remembered that this same charter, in the same terms, word for word, was sealed in Flanders under the king's great seal, that is to say, at Ghent, the 5th day of November in the 25 th year of the reign of our aforesaid lord the king, and sent into England.

\section{CONTEMPORARY EXPOSITION}

BARTHOLOMEW DE COTTON (1297)

His majesty the King conceded to all who owed him service and to all holders of twenty measures of land that they should not be held to go with him into Flanders except for the performance of promises and of military service due said King.

Bartholonew de Cotron, Historia Anglicana, translated by H. A. Clapp (1900). 327.

\section{CRITICAL COMMENT}

HALLAM (1818)

That famous statute, inadequately denominated the confirmation of the charters, because it added another pillar to our Constitution, is not less important than the great charter itself. Hitherto the King's prerogative of levying money. . . . had passed unquestioned. Some impositions, that especially on the export of wool, affected all the King's subjects. It was now the moment to enfranchise the people, and give that security to private property which Magna Charta had given to personal liberty. 
That the King could not impose taxes without the consent of parliament is admitted to have been, from time immemorial, a fundameutal law of England. It was among the articles which John was compelled by the Barons to sign. Edward I. ventured to break through the rule, but able, powerful, and popular as he was, he encountered an opposition to which he found it expedient to yield. He covenanted, accordingly in express terms, for himself and for his heirs, that they would never again levy any aid without the assent and good will of the estates of the realm.

MaCadLaY, History of England. I. 25.

STUBBS (1873)

The charters were confirmed by inspeximus on the 12th; the King on the 5th of November at Ghent confirmed both the charters and the new articles. These articles are the summary of the advantages gained at the termination of the struggle of eightytwo years, and in words they amount to very little more than a reinsertion of the clauses omitted from the Great Charter of John. The "Confirmatio Cartarum" is one of the most curious phenomena of our national history, whether it be regarded as the result of an occasional crisis, or as the decision, no longer to be delayed, of a struggle of principles. . . . The forces which seized that opportunity were ready, and were the result of a long series of causes and the working of principles which must sooner or later have made an opportunity for themselves. Such a crisis, if they had separately attempted to bring it about, might have changed the dynasty, or subverted the relations of church and state, crown and parliament, but accepted as it came, it brought about a result singularly in harmony with what seems from history and experience to be the natural direction of English progress.

William Stubbs, Constitutional History of England. II. 150, 151.

TASWELLLLANGMEAD (1879)

The "Confirmatio Chartarum," which, although a statute, is drawn up in the form of a charter, was passed on the 10th of 
October, 1297, in a Parliament at which Knights of the Shire attended as representatives of the Commons, as well as lay and clerical baronage. . . . The "Confirmatio Chartarum" was not merely a re-issue of Magna Charta and the Charter of the Forest, - but the enaetment of a series of new provisions intended to deprive the Crown in the future of its assumed right of arbitrary taxation. . . The exclusive right of Parliament to impose taxation, though often infringed by the illegal exercise of prerogative, became from this time an axiom of the Constitution.

T. P. Taswell-Langmead, English Constitutional History. $216,217$.

FEILDEN (1882)

The reign of Edward $I$. is marked by the admission of the Commons to Parliament, and by the partial surrender on the part of the Crown of its claims to arbitrary taxation. In 1297, Humphrey Bohun, Earl of Hereford, Roger Bigod, Earl of Norfolk, and Archbishop Winchelsey, representing baronial and clerical interests, extorted from Edward the Confirmatio Chartarum.

H. Sr. C. Ferluden, Short Constitutional History of England. 18.

RUDOLF VON GNEIST (1889)

This Confirmatio Chartarum, in French and Latin text, represents, in fact, a fundamental law comparable with Magna Charta, and to the credit of the Crown in contrast with the events of 1215 . . . The main point . . was that the right constantly contended for since Magna Charta in 1215 of signifying an assent to the taxes, had after a lapse of a century been at last achieved, and this on a broad footing of the landowning classes, which in fact pay them.

Rudoly vox Gneist, History of the Eng. Parliament, translated by $\mathbf{A} . \mathbf{H}$. Keane. I. 159.

\section{HANNIS TAYLOR (1889)}

Not until eighty years after the issuance of the Great Charter did the nation finally win, through the Confirmatio Cartarum, a permanent constitutional guarantee that taxes should never be imposed by the unaided force of the royal authority. . . . 
In the parliament of 1295 the three estates appeared in person or by representatives : the lay and spiritual baronage represented themselves, the inferior clergy and the commons, each as an estate of the realm, appeared through their chosen representatives. 'Two years after the national assembly was thus constituted, the long struggle of the nation for the right to tax itself was closed at the end of the "Barons' War" by the Confirmatio Cartarum, wherein Edward I. was made to promise the clergy, the barons and " all the commonalty of the land, that for no business from henceforth will we take such manner of aids, tasks, nor prizes, but by the eommon assent of the realm, and for the common profit thereof, saving the ancient aids and prizes due and accustomed."

Hannis Taylor, Origin and Growth of the English Constitution. II. 11-13. 


\section{Chapter V}

\section{LEGAL FORMS AND TURY TRIALS (1429)}

\section{SUGGESTIONS}

The Statute 8 Henry VI. 12 is chosen as the type of the many statutes enacted in the Lancastrian Period. Referred to by Sir John Fortescue (whose interpretation of the English laws of the fifteenth century forms a running commentary upon the government of his day) this statute seems particularly worthy of place amongst our documents. This is the earliest mention, in a statute, of the system of trial by jury - "Inquest to be taken of lawful men."

The system of judicature is too technical and too far-reaching to be developed as a correlation of constitutional government, but it is well to give a cursory glance at Curia Regis, the Laws of Menry II., and the growth of Trial by Jury, that the principle of "liberty of the subject" may here be shown to have a legal as well as a moral support in the history of Anglo-Saxon government.

Throughout the earlier study, suggested by the topics in the Appendix, the development of the court and trial by jury are constantly referred to as a basis for research.

For Outlines and Material, see Appendix A.

\section{DOCUMENT}

\section{Statutes: 8 Henry VI. Cap. I2 (I429)}

No Judgment or Record shall be reversed for any The Statutes Writ, Process, \&c., rased. What Defects in Records at Large, i., may be amended by the Judges, and what not. 550,551 .

Item, our Lord the King had ordained and established by the authority of this present parliament, That for error assigned, or to be assigned, in any record, process, or warrant of attorney, original Assured digwrit or judicial, panel or return, in any places of nity of a war. the same rased or interlined, or in any addition, 
subtraction, or diminution of words, letters, titles, or parcel of letters, found in any such record, process, warrant of attorney, writ, panel, or return, which rasings, interlinings, addition, subtraction, or diminution, at the discretion of the King's judges of the courts and places, in which the said records or process by writ of error, or otherwise, be certified, do appear suspected, no judgment nor record shall be reversed nor adnulled.

II. And that the King's judges of the courts and places in which any record, process, word, plea,

Changes to be made by judges if needful.
Exceptions: return; (2) except appeals, indictments of treason records not to and of felonies, and the outlawries of the same, and be amended in certain cases.

the substance of the proper names, surnames, and additions, left out in original writs and writs of exigent, according to the statute another time made the first year of King Henry, father to our lord the King that now is, and in other writs containing Judges' right proclamation; (3) so that by such misprision of the to correct variance between record and certificate of same. clerk no judgment shall be reversed nor adnulled. (4) And if any record, process, writ, warrant of attorney, return, or panel be certified defective, otherwise than according to the writing which thereof remaineth in the treasury, courts, or places from whence they be certified, the parties in affirmance of the judgments of such record and process shall have advantage to alledge, that the same writing is variant from the said certificate, and that found and certified, the same variance shall be by the said judges reformed and amended according to the first writing. 
III. And moreover it is ordained, that if any record, or parcel of the same writ, return, panel, process, or warrant of attorney in the King's courts of chancery, exchequer, the one bench or the other, or in his treasury, be willingly stolen, taken away, withdrawn, or avoided by any clerk, or by other person, because whereof any judgment shall be reversed; that such stealer, taker away, withdrawer, or avoider, their procurators, counsellors, and abet- Punishment tors, thereof indicted, and by process thereupon made thereof duly convict by their own confession, to be felony. or by inquest to be taken of lawful men, whereof the one half shall be of the men of any court of the same courts, and the other half of other, shall be judged for felons, and shall incur the pain of felony. (2) And that the judges of the said courts of the one bench or of the other, have power to hear and determine such defaults before them, and thereof to make due punishment as afore is said.

IV. Provided always, That if any such record, process, writ, or warrant of attorney, panel, or return, or parcel of the same, be now, cr hereafter shall be exemplified in the King's chanery under the great seal, and such exemplification there of record inrolled without any rasing in the same place in the exemplification and the inrollment of the same, that anotler time for any error assigned, or to be assigned in the said record, process, writ, warrant of attorney, panel, or return, in any letter, Power of the word, clause, or matter of the same varying, or contrary to the said exemplification and the inrollment, there shall be no judgment of the said records and process reversed nor adnulled.

\section{CONTEMPORARY EXPOSITION}

FORTESCUE (1450)

The way of proceeding in civil cases.

Twelve Good and true Men being sworn, as in the Manner above related, legally qualified, that is, having over and besides 
their Moveables, Possessions in Land sufficient (as was said) wherewith to maintain their Rank and Station; neither suspected by, nor at Variance with either of the Parties; all of the Neighbourhood; there shall be read to them, in English, by the Court, the (a) Record and Nature of the Plea, at length, which is depending between the Parties; and the Issue thereupon sliall be plainly laid before them, concerning the Truth of which, those who are so sworn, are to certify the Court: Which done, each of the Parties, by (b) Themselves or their Counsel, in Presence of the Court, shall declare and lay open to the Jury all and singular the Matters and Evidences, whereby they think they may be able to inform the Court concerning the Truth of the Point in Question; after which each of the Parties has a Liberty to produce before the Court all such Witnesses as they please, or can get to appear on their Behalf; who being charged upon their Oaths, shall give in Evidence all that they know touching the Truth of the Fact, concerning which the Parties are at Issue: And, if Necessity so require, the Witnesses may be heard and examined apart, till they shall have deposed all that they have to give in Evidence, so that what the One has declared shall not inform or induce another Witness of the same Side, to give his Evidence in the same Words, or to the very same Effect. The whole of the Evidence being gone thro', the Jurors shall confer together, at their Pleasure, as they shall think most convenient, upon the Truth of the Issue before them; with as much deliberation and Leisure as they can well desire, being all the While in the Keeping of an Officer of the Court, in a Place assigned them for that Purpose, Lest any One should attempt by indirect Methods to influence them as to their Opinion, which they are to give in to the Court. Lastly, They are to return into Court and certify the Justices upon the Truth of the Issue so joined, in the Preseuce of the Parties (if they please to be present) particularly the Person who is Plaintiff in the Cause; what the Jurors shall so certify in the Laws of England, is called (c) the Verdict. In Pursuance of which Verdict, the Justices shall render and form their Judgment. Notwithstanding, if the (d) Party, against whom such Verdict is obtained, complain that $\mathrm{He}$ is thereby aggrieved, He may sue out a Writ of Attaint, both against the Jury, and also against the Party 
who obtained it: in Virtue of which, if it be found upon the Oath of (e) 'Twenty-four Men (returned in Manner before observed, chosen and sworn in due Form of Law, who ought to have much better Estates than those who were first returned and sworn) that those, who were the Original Panel and sworn to try the Fact, have given a Verdict, $\mathrm{f}$ (15), contrary to Evidence, and their Oath; Every One of the first Jury shall be (g) committed to the Publick Gaol, their Goods shall be confiscated, their Possessions seised into the King's Hands, their Habitations and Houses shall be pulled down, their Woodlands shall be selled, their Meadows shall be plowed up, and they themselves shall ever thenceforward be esteemed, in the Eye of the Law, Infamous, and in no Case whatsoever, $h$ (16), are they to be admitted to give Evidence in any Court of Record: The Party, who suffered in the former 'Trial, shall be restored to every 'Thing they gave against Him, thro' Occasion of such their False Verdict: And, who then (tho' $\mathrm{He}$ should have no Regard to Conscience or Honesty) being so charged upon his Oath, would not declare the Truth from the bare Apprehensions and Shame of so Heary a Punishment, and the very great Infamy which attends a contrary Behaviour: And, if perhaps, one or more amongst them should be so unthinking or daring, as to prostitute their Character, yet the rest of the Jurors, probably, will set a better Value on their Reputations than to suffer either their Good Name or Possessions to be destroyed and seised in such a Manner: (i) Now, is not this Method of coming at the Truth better and more effectual, than that Way of Proceeding, which the Civil Laws prescribe? No one's Cause or Right is, in this Case, lost, either by Death or Failure of Witnesses. The (k) Jurors returned are well known; they are not procured for Hire; They are not of Inferior Condition; neither Strangers, nor People of Uncertain Characters, whose Circumstances or Prejudices may be unknown. The (k) Witnesses or Jurors are of the Neighbourhood, able to live of themselves, of Good Reputation and unexceptionable Characters, not brought before the Court by citlier of the Parties, but (l) chosen and returned by a proper Officer, a worthy, disinterested and indifferent Person, and obliged under a Penalty to appear upon the Trial. (k) They are well acquainted with all 
the Facts which the Evidiences depose, and with their several Characters. (m) What need of more Words? 'There is nothing omitted which can discover the 'Truth of the Case at Issue, nothing which ean in any Respect be concealed from, or unknown to a Jury who are so appointed and returned, I say, as far as it is possible for the Wit of Man to devise.

Sir Joun Fortescer, De Laudibus Legis Anglice. XXVI. (civl. 1450).

\section{SAINT-GERMAIN (1518)}

Doctor. If one of the twelve men of an inquest know the very truth of his own knowledge, and instructeth his fellows thereof, and they will in no wise give credence to him, and thereupon, because meat and drink is prohibited them, he is given to that point, that either he must assent to them, and give their verdict against his own knowledge and against his own conscience, or die for lack of meat, how may the law then stand with conscience, that will drive an innocent to that extremity, to be either forsworn, or to be famished and die for want of meat?

Student. I take not the law of the realm to be, that the jury after they be sworn may not eat nor drink till they be agreed of the verdict, but truth it is there is a maxime and an old custom in the law that they shall not eat nor drink after they be sworn till they have given their verdict, without the assent and license of the justices and that is ordained by the law for eschewing divers inconveniences that might follow thereupon, and that specially if they should eat or drink at the costs of the parties; and therefore if they do contrary, it may be laid in arrest of the judgment; but with the assent of the justices they may both eat and drink, as if any of the jurors fall sick before they be agreed of the verdict, so sore that he may not commune of the verdict, then by the assent of the justices he may have meat and drink, and also such other things as be necessary for him.

Christopher Saint-Germain, The Doctor and The Student. 158.

\section{CRITICAL COMMENT}

BLACKSTONE'S COMMENTARIES (1765)

The learned judge has displayed much erudition in the beginning of this chapter to prove the antiquity of the trial by 
jury; but the trials referred to by the authors there cited, and even the judicium parium [the judgment of peers] mentioned in the celebrated ehapter of Magna Charta, are trials which were something similar to that by a jury, rather than instances of a trial by jury according to the present established form. The judicium parium seems strictly the judgment of a subject's equals in the feudal courts of the king and barons. And so little appears to be ascertained by antiquarians respecting the introduction of the trial in criminal cases by two juries, that although it is one of the most important, it is certainly one of the most obscure and inexplicable, parts of the law of England. The unanimity of twelve men, so repugnant to all experience of human conduct, passions, and understandings, could hardly in any age have been introduced into practice by a deliberate act of the legislature.

But that the life, and perhaps the liberty and property, of a subject should not be affected by the concurring judgment of a less number than twelve, where more were present, was a law founded in reason and caution, and seems to be transmitted to us by the common law, or from immemorial antiquity. The grand assize might have consisted of more than twelve, yet the verdict might have been given by twelve or more; and if twelve did not agree, the assize was afforced, - that is, others were added till twelve did concur. . . . This was a majority, and not unanimity. A grand jury may consist of any number from twelve to twenty-three inclusive, but a presentment ought not to be made by less than twelve. . . . The same is true also of an inquisition before the coroner. In the high court of parliament and the court of the lord high steward a peer may be convieted by the greater number; yet there can be no conviction unless the greater number consists at least of twelve. . . Under a commission of lunacy the jury was seventeen, but twelve joined in the verdict. . . . A jury upon a writ of inquiry may be more than twelve. In all these cases, if twelve only appeared, it followed as a necessary consequence that to act with effect they must have been unanimous. Hence this may be suggested as a conjecture respecting the origin of the unanimity of juries, that, as less than twelve - if twelve or more were present-could pronounce no effective 
verdict, when twelve only were sworn, their unanimity became indispensable.

Sir William Blackstone, Commentaries on the Laws of England. III. 376.

\section{GEORGE SPENCE (1846)}

The exercise of the control last adverted to on the part of the judges was the foundation of that system of rules in regard to evidence which has since constituted so large and important a branch of the law of England.

The practice of receiving evidence openly at the bar immediately led to another remarkable result - namely, the great extension of the duty of an advocate. "In earlier timesupon eriminal as well as civil inquiries - the jury after they had been sworn and merely charged by the court as to the points at issue, retired to consult together in secret without hearing either witnesses or counsel at the bar. But now the scene was totally changed; witnesses were examined and cross-examined in open court; the floodgates of forensic eloquence were opened, and full scope given to the advocate to exercise his ingenuity and powers of persuasion on the jurors, to whose discretion the power of judging on matters of fact was now intrusted."

Another important consequence followed - when the jury in an assize gave or were presumed to give their verdict upon facts within their knowledge, if they came to a wrong decision they must usually have been guilty of perjury. When they became judges of the facts upon evidence, the liability to attaint would have been as unreasonable and unjust as in the case of an ordinary jury: it therefore virtually fell into disuse. Thenceforth the means of correcting error and mistake on the part of a jury, was left without adequate remedy by the courts of law until the seventeenth century, when the practice of granting new trials was introduced, which I shall have occasion again to advert to in tracing the equitable jurisdiction of the Court of Chancery (1).

The last change in the institution of jury trial is of comparatively modern introduction; it is the limiting the functions of the jury to that of being judges of fact upon evidence laid before them. The principles, Mr. Starkie observes, which warranted this change are obvious; it was found that the 
cause of truth suffered more from the prejudices which the residence of jurors in the neighbourhood of the disputed fact were likely to engender, than was gained from knowledge and means of judging so acquired (2). Other inconveniences arose from the rules as to the Venue, so that, after various modifications as to the number of persons from the hundred or vicinage that were to be put upon the jury by the Stat. $4 \& 5$ Anne, c. 16, and 24 Geo. II., c. 18, the law requiring jurors to be returned from the vicinage or hundred was abolished in all civil actions and it was directed that they should be summoned from the body of the county. By a decision of the Court of Queen's Bench in the first year of Queen Anne, it was held that if a jury gave a verdict of their own knowledge, they ought so to inform the Court, that they might be sworn as witnesses. This, and another case in the reign of George I. put an end to all remains of the ancient functions of juries as recognitors. The question, therefore, adds Mr. Starkie, When did the trial by jury begin? admits of no definite answer, otherwise than by referring to the different transitions to which allusion has been made (3).

George Spence, Equitable Jurisdiction of the Court of Chancery. I. 129.

\section{FORSYTH (1852)}

The rise and growth of the Jury system is a subject which ought to interest not only the lawyer but all who value the institutions of England, of which this is one of the most remarkable, being until recently a distinctive feature of our jurisprudence. . . . Trial by Jury does not owe its existence to any positive law:- it is not the creature of an Act of Parliament establishing the form and defining the functions of the new tribunal. It arose, as I hope to show, silently and gradually out of the usages of a state of society which has forever passed away. . . . Few subjects have exercised the ingenuity and baffled the research of the historian more than the origin of the jury. . . I believe it to be capable almost of demonstration, that the English jury is of indigenous growth, and was not eopied or borrowed from any of the tribunals that existed on the continent. . . .

The first mention of the trial by assise in our existing 
statutes occurs in the Constitutions of Clarendon, A. D. 1164, where it was provided that if any dispute arose between a layman and a clerk as to whether a particular tenement was the property of the church or belonged to a lay fief, this was to be determined before the chief justiciary of the kingdom, by the verdict of twelve lawful men... The problem is to discover what was the origin and constitution of the jurata. . .

I conclude that, in the earliest times, disputes respecting lands were decided by the voice of the community of the county or hundred, as the case might be, where the parties lived, that afterwards a select number was substituted for the whole, who gave their testimony upon oath, and therefore were called the 'jurata;' and that this suggested to Henry II. and his councillors the idea of the assise, which was nothing but the jurata in a technical form, and limited to milites, or knights who were summoned by a writ of the sheriff in virtue of a precept from the king. . . .

As the use of juries became more frequent, and the advantages of employing them in the decision of disputes more manifest, the witnesses who formed the secta of a plaintiff began to give their evidence before them, and, like the attesting witnesses to deeds, furnished them with that information which in theory they were supposed to possess previously respecting the cause of quarrel. . . .

In the time of Fortescue, who was lord chancellor in the reign of Henry VI., with the exception of the requirement of personal knowledge in the jurors derived from near neighbourhood of residence, the jury system had become in all its essential features similar to what now exists. . . .

In Eugland, the jury and the witnesses were for many years the same, so that it was only just that they should be punished if they wilfully gave their evidence, that is their verdict, contrary to what they knew to be the truth. And this seems to have been too common. In the tenth year of the reign of Henry VI. a petition was presented to the Commons, complaining of the disherisons and injustice committed in assises and other inquests by perjured jurors, and praying that in a writ of attaint the plaintiff may recover his damages against the petit jury, and every member thereof, as well as against 
the defendant, and that no juror might serve on an attaint unless be had an estate of five pounds a year in the county.

William Forsyti, History of Trialby Jury. 1-185.

J. R. GREEN (1874)

The Wars of the Roses did far more than ruin one royal house or set up another on the throne. If they did not utterly destroy English freedom, they arrested its progress for more than a hundred years. They found England, in the words of Commines, "among all the world's lordships of which I have knowledge, that where the public weal is best ordered, and where least violence reigns over the people." A King of England - the shrewd observer noticed - "can undertake no enterprise of account without assembling his Parliament, which is a thing most wise and holy, and therefore are these kings stronger and better served" than the despotic sovereigns of the Continent. The English kingship, as a judge, Sir John Fortescue, could boast when writing at this time, was not an absolute but a limited monarchy; the land was not a land where the will of the prince was itself the law, but where the prince could neither make laws nor impose taxes save by his subjects' consent. At no time had Parliament played so constant and prominent a part in the government of the realm. At no time had the principles of constitutional liberty seemed so thoroughly understood and so dear to the people at large. The long Parliamentary contest between the Crown and the two Houses since the days of Edward the First had firmly established the great securities of national liberty - the right of freedom from arbitrary taxation, from arbitrary legislation, from arbitrary imprisonment, and the responsibility of oven the highest servants of the Crown to Parliament and to the law. But with the close of the struggle for the succession this liberty suddenly disappears. We enter on an epoch of constitutional retrogression in which the slow work of the age that went before it was rapidly undone. Parliamentary life was almost suspended, or was turned into a mere form by the overpowering influence of the Crown. The legislative powers of the two Houses were usurped by the royal Council.

J. R. Green, Short History of the English People. 289, 290. 


\section{TASWELL-LANGMEAD (1879)}

The use of a Jury, both for criminal presentment and civil inquest, is mentioned for the first time in our statute law in the Constitutions of Clarendon. The way in which the jury is therein referred to seems to imply that it had already grown into general use and favour. When one could be found to accuse a powerful layman amenable to the Bishop's jurisdiction, the sheriffs, at the Bishop's request, were direeted to "swear twelve lawful men of the neighbourhood to tell the truth, according to their conscience," and the same statute declared that "by the recognition of twelve lawful men," the Chief Justice should decide all disputes as to the lay or clerical tenure of land.

It was in the Grand Assize (the exact date of which is unknown) that the principle of recognition by jury, having gradually grown into familiar use in various civil matters, was applied by Henry II., in an expanded and technical form, to the decision of suits to try the right to land. It is described by Glanvill as a Royal boon conferred on the people, with the counsel and consent of the proceres, to relieve freeholders from the hardship of defending the title to their lands by the doubtful issue of trial by battle. By the Grand Assize the defendant was allowed his choice between wager of battle and the recognition (i. e., knowledge) of a jury of twelve sworn knights of the vicinage summoned for that purpose by the sheriff.

In actions not seeking to determine the absolute right to land, but dealing with the seisin only (of which the "assize of novel disseisin" was the most important), the sheriff himself chose twelve knights or freeholders (legales homines) of the vicinage, who were sworn to try the question. In both cases the recognitors were sworn to found their verdict upon their own knowledge, gained either by eye-witness or by the words of their fathers, or by such words as they are bound to have as much confidence in as if they were their own. The proceeding by assize was in fact merely the sworn testimony of a certain number of persons summoned to give evidence upon matters within their own knowledge. They were themselves the only witnesses. If all were ignorant of the facts, a fresh jury had to be summoned; if some of them only were ignorant, 
or if they could not agree, others were to be added - a process subsequently called afforcing the jury - until a verdict could be obtained from twelve unanimous witnesses.

The remedy by Assize was subsequently improved by several Acts of Parliament, particularly 13 Ed. I. c. 25 ; and as all actions on the assize were tried in the King's Court or in that of the Justices Itinerant, the jurisdiction of the County and Hundred Courts began, from this period, rapidly to decline.

By the Assize of Clarendon the principle of Recognition by jury was extended to criminal cases. It was ordained that in every county twelve lawful men of each hundred, with four lawful men from each township, should be sworn to present all reputed eriminals of their district in each County court. The persons so presented were to be at once seized and sent to the water ordeal. This was simply a reconstitntion or revival, in an expanded form, of the old English institution analogous to a Grand Jury, which, as we have seen, had existed at least since the time of King Ethelred II.

By the Articles of Visitation issued under Richard I. in 1194, as instructions to the Itinerant Justices, the election and constitution of the Jury of Presentment established by Henry II. was furtlier regulated, and assimilated to the system already in use for nominating the recognitors of the Grand Assize. From this developed Jury of Presentment our present Grand Jury has historically descended.

The establishment of this system of combined presentment and ordeal had the effect of abolishing, in all criminal cases, the ancient practice of compurgation by the oath of friends, the "manifest fountain of unblushing perjury."

In the year 1215 the ordeal was abolished throughout Christendom by the fourth Lateran Council, and there remained only, for criminal trials in England, the Grand Jury and the Combat. But the Combat was not applicable unless an injured prosecutor, or " appellant," came forward to demand it; and as the Grand Jury was found inadequate to secure perfect justice, the practice (which had been introduced even before the abolition of ordeal) gradually grew up of allowing a second, or Petit Jury to affirm, or traverse, the testimony of the first set of inquest men. This became the general usage in the reign of 
Henry III. Still for a long time no prisoner was compellable to plead, that is, he might refuse to be tried by the jury: but in this case he was remanded to prison, and from the date of the Statute of Westminster I. (3 Edward I.) was liable to the barbarous punishment called peine forte et dure, which was only abolished so late as the reign of George III.

It is important to bear in mind that in 'Trial by Jury as permanently established, both in Civil and Criminal Cases, by Henry II., the function of the Jury long continued very different from that of the modern tribunal. The jurymen were still mere recognitors, deciding simply on their own knowledge or from tradition, and not upon evidence produced before them; and it was for this reason that they were always selected from the hundred or vicinage in which the question arose.

The later development, common to the Civil and Criminal Jury alike, by which the jurors gradually changed from witnesses into judges of fact, the proof of which rested exclusively on the evidence of others, has now to be considered. The number of the recognitors was at first undefined, but when Glanvill wrote, under Henry II., twelve appears to have been the usual, though not the invariable, number mentioned in the King's writs. We have seen that it was necessary that twelve jurymen should concur in their verdict, and this result, in Civil cases at least, was procured by "afforcing" the jury, that is, adding other recognitors from the vicinage who were acquainted with the matter. But the difficulty of procuring a verdict of twelve, caused for a time the verdict of a majority to be received. In the reign of Edward III., however, the necessity for a unanimous verdict of twelve was re-established.

Under Henry III., special witnesses (such as the witnesses to a deed) were sometimes summoned together with, and formed part of, the Jury.

In the Year Books of 23rd Edward III. mention is made of witnesses being adjoined to the Jury to give them their testimony, but without having any voice in the verdict. This is the first indication of the Jury deciding on evidence formally produced in addition to their own knowledge, and forms the connecting link between the ancient and the modern Jury.

Early in the reign of Henry IV. a further advance was made, 
All evidence was required to be given at the bar of the court, so that the Judges might be enabled to exclude improper testimony.

From this change flowed two important consequences: (1) From the exercise of control on the part of the Judges sprang up the whole systems of rules as to evidence. (2) The practice of receiving evidence openly at the bar of the Court produced a great extension of the duty of an advocate. Henceforward "witnesses were examined and cross-examined in open court; the floodgates of forensic eloquence were opened, and full scope given to the advocate to exercise his ingenuity and power of persuasion on the jurors, to whose discretion the power of judging on matters of fact were now intrusted."

In the treatise of Chief Justice Fortescue, "De Landibus Legum Angliæ," written soon after the year 1450 , we have clear evidence that the mode of procedure before juries by vivâ voce evidence was the same as at present.

But Juries were still for a long time entitled to rely on their own knowledge in addition to the evidence. In the first year of Queen Anne, the Court of Queen's Bench decided that if a Jury gave a verdict of their own knowledge, they ought so to inform the Court, that they might be swom as witnesses. This, and a subsequent case in the reign of George I., at length put an end to all remains of the ancient functions of Juries as Recognitors.

In the same way the ancient rule requiring jurors to be returned from the vicinage or hundred, which arose when jurymen were themselves the witnesses, was, after various modifications, abolished in all Civil actions in the reign of George II., and it was directed that juries should be summoned from the body of the county.

T. 1. Tasweld-Langmead, English Constitutional History. 136-141.

\section{HANNIS TAYLOR (1889)}

No attempt to outline the form which the English constitutional system assumed during the fonrtcenth and fifteenth centuries should fail to embrace some allusion to the aceounts given of that system by Sir John Fortescue, the great Lancastrian lawyer, who attended Queen Margaret in her exile 
on the Continent, where he seems to have undertaken, for a time at least, the political education of the heir-apparent. From the De Laudibus Legum Angliae, which was designed to instruct the prince how he should rule over the English; from the De Dominio Regali et Politico, a Treatise on Absolute and Limited Monarchy, and in particular on the Monarchy of England; and from the De Natura Legis Naturae, it is possible to draw something like a definite idea of the extent to which the English kingship had become limited towards the end of the fifteenth century by the growth of the parliament on the one hand, and by growth of the system of legal administration on the other. Under the influence of mediæval political ideas, the writer divides all governments into three classes; the first of which he describes as regal government (dominium regale), the second as political government (dominium politicum), and the third as goverument of a mixed nature, regal and political (dominium regale et politicum). To the third class England belongs. ...

In England the king "cannot by himself or his ministers lay taxes, subsidies, or any imposition of what kind soever, upon the subject; he cannot alter the laws, or make new ones, without the express consent of the whole kingdom in parliament assembled." Sir John, who had been chief justice of the king's bench, while explaining how the liberties of the nation as a whole were protected by the parliamentary system, did not forget to point out how the life, liberty, and property of the individual subject were guarded by the system of legal administration. In the account given of the provisions made for the local administration of justice, a careful statement is contained of the procedure in jury trials both in civil and criminal cases. In a civil case the issue is tried by an impartial jury taken from the neighbourhood; in a capital case the jury is not only selected impartially from the neighbourhood, but the defendant is given a large number of challenges, for which he need assign no cause or reason. "In a prosecution carried on in this manner there is nothing cruel, nothing inhuman; an innocent person cannot suffer in life or limb; he has no reason to dread the prejudice or calumny of his enemies; he will not, can not, be put to the rack to gratify 
their will and pleasure. In such a constitution, under such laws, every man may live safely and securely."

Thus by the middle of the fifteenth century the personal and political rights of the English people, which had long before been defined in statutes and charters, were permanently and practically guaranteed to the nation as a whole by the parliamentary system on the one hand and to the individual subject by the jury system on the other.

Hannis Taylor, Origin and Growth of the English Constitution. I. 560-562.

STEVENS (1894)

And later on, jurors without information were separated from those possessing it, the former becoming judges of evidence only, and the latter witnesses; a decision being given by the former upon the testimony of the latter, and the law in the case being decided by the presiding official in the king's name. By 1450 we have distinct evidence that the mode of procedure was the same as that in modern use, though in occasional instances the ancient functions of jurors lingered as late as to the accession of the House of Hanover.

C. E. Stevens, Sources of the Constitution of the United States. 237. 


\section{Chapter VI \\ PETITION OF RIGHT}

\section{SUGGESTIONS}

Tris document - Petition of Right - was the result of the struggle between King Charles I. and the members of Parliament. A Committee of Grievances, members of the third Parliament (March to Jnne, 1828), met together to consider what steps should be taken to restore ancient laws and liberties. For two months the attention of both Houses, either in conference or in separate debate, was almost exclusively devoted to this important subject.

The King attempted to satisfy the House of Commons by a simple confirmation of Magna Charta, but Sir Edward Coke warned the House to proceed by Bill. In fact the far-famed Petition may be said to have thriven under the especial tutelage of Sir Edward Coke: the part assigned to him was the application of reasons for the laws and precedents which had been quoted in favour of the contentions of Parliament. When Charles I. suggested confirming Magna Charta without additions, paragraphs, or explanations, Coke said - "Let us put up a Petition of Right: not that I distrust the King, but that I cannot take his trust but in a parlianentary way."

The Petition of Right was then drawn up by the Commons. After much discussion on the part of both the House of Lords and the House of Commons the petition was passed without any material alteration. On the 2nd of June, 1628, the King attended in the House of Lords to give his answer to the Bill. To the great surprise of Peers and Commoners, the King returned a long and equivocal answer, amounting almost to a refusal to pass the Bill. The Commons gave vent to their ill-humour by impeaching Dr. Mainwaring, one of the Royal Councillors, and were proceeding to censure the favourite, Buckingham, when, on June 7th, the King signed the great contract in the usual form.

This great constitutional compact between the Crown and the People demands peculiar investigation. The documeuts earlier cited have had no masterful personality standing behind them. The history of this document is closely connected with the heroes of the Puritan era, and the personal preferences and legal theories of Pym, 
Hampden, Sir Jolın Eliot, and Sir Edward Coke are expressed in almost every word in the petition. The close conuection between the British subject at home and in the colonies, even at this early period in colonial history, should be taken in to consideration. The dominant spirit of " redress," as emphatically expressed in 1628, was the cornerstone of all later petitions addressed to royal authority.

For Outlines and Material, see Appendix A.

\section{DOCUMENT}

\section{Petition of Right (June 7, 1628 )}

The Petition exhibited to his Majesty by the Lords The Statutes Spiritual and Temporal, and Commons, in this of the Realm, present Parliament assembled, concerning divers $\begin{aligned} & \mathrm{v} . \\ & \text { translated }\end{aligned}$ Rights and Liberties of the Subjects, with the by William King's Majesty's royal answer thereunto in full Stubbs, Parliament.

Select Charters, 505-507.

To the King's Most Excellent Majesty,

Humbly show unto our Sovereign Lord the King, Third Parliathe Lords Spiritual and 'Temporal, and Commons in Charles I. is Parliament assembled, that whereas it is declared forced to and enacted by a statute made in the time of the "Petition of reign of King Edward I., commonly called Statutum Right." de Tallagio non concedendo, that no tallage or aid "Deciarashall be laid or levied by the king or his heirs in tory statut this realm, without the good will and assent of the former acts archbishops, bishops, earls, barons, knights, burgesses, and other the freemen of the eommonalty of illegal. The so-called this realm; and by authority of parliament holden has been in the five-and-twentieth year of the reign of King termed a in the five-and-twentieth year of the reign of King compendium Edward III., it is declared and enacted, that from of Confirmathenceforth no person shall be compelled to make tio Charta-
rum. VI. any loans to the king against his will, because such loans were against reason and the franehise of the land; and by other laws of this realm it is provided, that none sliould be charged by any charge or imposition, called a benerolenee, nor by such like eharge ; by which the statutes before mentioned, and other the good laws and statutes of this realm, your subjeets have inherited this freedom, that they should 
not be compelled to contribute to any tax, tallage, aid, or other like charge not set by common consent, in parliament:

"Benevolences" first enacted in the reign of Edward IV. (1473): they were analogous to forced loans in preceding reigns.

Magna Charta's Habeas Corpus.
II. Yet nevertheless of late divers commissions directed to sundry commissioners in several counties, with instructions, have issued; by means whereof your people have been in divers places assembled, and required to lend certain sums of money unto your Majesty, and many of them, upon their refusal so to do, have had an oath administered unto them not warrantable by the laws or statutes of this realm, and have been coustrained to become bound and make appearance and give utterance before your Privy Council, and in other places, and others of them have been therefore imprisoned, confined, and sundry other ways molested and disquieted; and divers other charges have been laid and levied upon your people in several counties by lord lieutenants, deputy lieutenants, commissioners for musters, justices of peace and others, by command or direction from your Majesty or your Privy Council, against the laws and free customs of the realm.

III. And whereas also by the statute ealled "The Great Charter of the liberties of England," it is declared and enacted that no freeman may be taken or imprisoned or be disseised of his freeholds, or liberties, or his free customs, or be outlawed or This statute, exiled, or in any manner destroyed, but by the "liberty of ", lawful judgment of his peers, or by the law of the the subject," lawd.

Magna

Charta, Art. xxxix.
IV. And in the eight-and-twentieth year of the reign of King Edward III., it was declared and enacted by authority of parliament, that no man, of what estate or condition that he be, should be put out of his lands or tenements, nor taken, nor imprisoned, nor disherited, nor put to death without being brought to answer by due process of law.

V. Nevertheless, against the tenor of the said statutes, and other the good laws and statutes of 
your realm to that end provided, divers of your subjects have of late been imprisoned without any cause showed; and when for their deliverance they were brought before your justices, by your Majesty's writs of habeas corpus, there to undergo and receive These subas the court should order, and their keepers com- jects were manded to certify the causes of their detainer, no bers of Parcause was certified, but that they were detained by liament, your Majesty's special command, signified by the for urisoned lords of your Privy Council, and yet were returned ances on the back to several prisons, without being charged with floor of the anything to which they might make answer accord- Commons. ing to the law.

VI. And whereas of late great companies of soldiers and mariners have been dispersed into divers counties of the realm, and the inhabitants against Billeting soldiers and their wills have been compelled to receive them into mariners their houses, and there to suffer them to sojourn was valid against the laws and customs of this realm, and to time of war. the great grievance and vexation of the people:

VII. And whereas also by authority of parliament, in the five-and-twentieth year of the reign of King Edward III., it is declared and enacted, that no man shall be forejudged of life or limb against the form of the Great Charter and the law of the land; and by the said Great Charter, and other the laws and statutes of this your realm, no man ought to be adjudged to death but by the laws established in this your realm, either by the customs of the same realm or by acts of parliament: and whereas no offender of what kind soever is exempted from the proceedings to be used, and punishments to be inflicted by the laws and statutes of this your realm: nevertheless of late time divers commissions under your Majesty's great seal have issued forth, by which certain persons have been assigned and appointed commissioners with power and authority to proceed within the land, according to the justice Martial Law of martial law, against such soldiers or mariners, or to statute 25 
Edward

III.'s,

though

Elizabeth

and Charles

I. did not

hesitate to apply martial law to civilians in times of peace.

Colour $=$ (apparent right). other dissolute persons joining with them, as should commit any murder, robbery, felony, mutiny, or other outrage or misdemeanour whatsoever, and by such summary course and order as is agreeable to martial law, and as is used in armies in time of war, to proceed to the trial and condemnation of such offenders, and them to cause to be executed and put to death according to the law martial.

VIII. By pretext whereof some of your Majesty's subjects have been by some of the said commissioners put to death, when and where, if by the laws and statutes of the land they had deserved death, by the same laws and statutes also they might, and by no other ought to have been, judged and executed.

IX. And also sundry grievous offenders, by colour thereof elaiming an exemption, have escaped the punishments due to them by the laws and statutes of this your realm, by reason that divers of your officers and ministers of justice have unjustly refused or forborne to proceed against such offenders according to the same laws and statutes, upon pretence that the said offenders were punishable only by martial law, and by authority of such eommissions as aforesaid; which commissions, and all other of like nature, are wholly and directly contrary to the said laws and statutes of this your realm.

$\mathrm{X}$. They do therefore humbly pray your most excellent Majesty, that no man hereafter be compelled to make or yield any gift, loan, benevolence, tax, or such like charge, without common consent by act of parliament: and that none be called to make answer, or take such oath, or to give attendance, or be confined, or otherwise molested or disquieted concerning the same or for refusal thereof; and that no freeman, in any such manner as is befor'e mentioned, be imprisoned or detained; and that your Majesty would be pleased to remove the said soldiers and mariners, and that your people may not 
be so burdened in time to come ; and that the foresaid commissions, for proceeding by martial law, may be revoked and annulled; and that hereafter no comınissions of like nature may issue forth to any person or persons whatsoever to be executed as aforesaid, lest by colour of them any of your Majesty's subjects be destroyed or put to death contrary to the laws and franchise of the land.

XI. All which they most humbly pray of your most excellent Majesty as their rights and liberties, according to the laws and statutes of this realm; and that your Majesty would also vouchsafe to declare, that the awards, doings, and proeeedings, to the prejudice of your people in any of the premises, shall not be drawn hereafter into consequence or example; and that your Majesty would be also graciously pleased, for the further comfort and safety of your people, to declare your royal will and pleasure, that in the things aforesaid all your officers and ministers shall serve you according to the laws and statutes of this realm, as they tender the honour of your Majesty, and the prosperity of this kingdom.

[Which Petition being read the 2nd of June, 1628, the king's answer was thus delivered unto it.

The King willeth that right be done according to the laws and customs of the realm; and that the statutes be put in due execution, that his subjects may have no cause to complain of any wrong or oppressions, contrary to their just rights and liberties, to the preservation whereof he holds himself as well obliged as of his prerogative.

This form was unusual and was therefore thought to be an evasion; therefore on June 7 the king gave a second answer in the formula usual for approving Soit droit bills : Soit droit fait comme il est désiré.]

il est désiré. 


\section{CONTEMPORARY EXPOSITION}

CHARLES FIRST (1628)

The profession of both Houses, in time of hammering this petition, was no ways to entrench upon my prerogative, saying they had neither intention or power to hurt it; therefore it must needs be conceived I granted no new, but only confirmed the ancient liberties of my subjects, yet to show the elearness of my intentions, that $I$ have neither repented nor mean to recede from anything $I$ have promised you, I do here declare that those things which have been done whereby men had some eause to suspect the liberty of the subjects to be entrenched uponwhich indeed was the first and true ground of the petitionshall not hereafter be drawn into example for your prejudice; and in time to come, in the word of a king, you shall not have the like cause to complain.

Charles First's Speech at Prorogation of Parliament, June 26th, 1628, Parliamentary History.

\section{CRITICAL COMMENT}

HALLAM (1827)

The principal matters of complaint taken up by the Commons in this session (Parliament, 1628) were, the exaction of money under the name of loans; the commitment of those who refused compliance, and the late decision of the king's bench remanding them a habeas corpus; the billeting of soldiers on private persons, which had occurred in the last years, whether for convenience or for purposes of intimidation and annoyance; and the commissions to try military offenders by martial law. . . . 'These four grievances or abuses form the foundation of the Petition of Right.

Henry Haliam, Constitutional History of England. VII. 286.

NUGENT (1831)

The government went on, oppressing at home, and blundering in all its measures abroad. A war was foolishly undertaken against France, and more foolishly conducted. Buckingham led an expedition against Rhé, and failed ignomin- 
iously. In the meantime, soldiers were billeted on the people. Crimes, of which ordinary justice should have taken cognizance, were punished by martial law. Nearly eighty gentlemen were imprisoned for refusing to contribute to the forced loan. The lower people, who showed any signs of insubordination, were pressed into the fleet or compelled to serve in the army. Money, however, came in slowly; and the king was compelled to summon another Parliament. In the hope of conciliating his subjects, he set at liberty the persons who had been imprisoned for refusing to comply with his unlawful demands. Hampden regained his freedom; and was immediately re-elected burgess for Wendover.

Early in 1628 the Parliament met. During its first session, the Commons prevailed on the king, after many delays and much equivocation, to give, in return for five subsidies, his full and solemn assent to that celebrated instrument - the second great charter of the liberties of England - known by the name of the Petition of Right. By agreeing to this act, the king bound himself to raise no taxes without the consent of Parliament, to imprison no man except by legal process, to billet no more soldiers on the people, and to leave the cognizance of offences to the ordinary tribunals.

In the summer this memorable Parliament was prorogued. It met again in January, 1629.

Buckingham was no more. That weak, violent, and dissolute adventurer, who, with no talents or acquirements but those of a mere courtier, had, in a great crisis of foreign and domestic politics, ventured on the part of prime minister, had fallen during the recess of Parliament, by the hand of an assassin. Both before and after his death, the war had been feebly and unsuccessfully conducted. The king had continued, in direct violation of the Petition of Right, to raise tonnage and poundage, without the consent of Parliament. The troops had again been billeted on the people; and it was clear to the Commons that the five subsidies which they had given, as the price of the national liberties, had been given in vain.

LonD Nrgest, Memorials of Hampden in Edinburgh Review. LIV. 516-517. 
The king called a third Parliament, and soon perceived that the opposition was stronger and fiercer than ever. He now determined on a change of tactics. Instead of opposing an inflexible resistance to the demands of the Commons, he, after much altercation and many evasions, agreed to a compromise which, if he had faithfully adhered to it, would have averted a long series of calamities. The parliament granted an ample supply. The king ratified, in the most solemn manner, that celebrated law which is known by the name of the Petition of Right, and which is the second great charter of the liberties of England. By ratifying that law, he bound himself never again to raise money without the consent of the Houses, never again to imprison any person, except in due course of law, and never again to subject his people to the jurisdiction of courts martial.

The day on which the royal sanction was, after many delays, solemnly given to this great act, was a day of joy and hope. The Commons, who crowded the bar of the House of Lords, broke forth into loud acclamations as soon as the clerk had pronounced the ancient form of words by which our princes have, during many ages, signified their assent to the wishes of the estates of the realm. Those acclamations were re-echoed by the voice of the capital and of the nation; but, within three weeks, it became manifest that Charles had no intention of observing the compact into which he had entered. The supply given by the representatives of the nation was collected. The promise by which that supply had been obtained was broken. A violent contest followed. The parliament was dissolved with every mark of royal displeasure.

Thomas Babington Macaudax, History of England. I. 66.

CREASY (1859)

On the 2nd of June, A. D. 1628 , the peers were assembled, the Commons summoned, and the king appeared in the House of Lords to give his answer in Parliament to the bill. But, to the surprise of all men, Charles. instead of using the wellknown ancient form of words by which such a bill receives the royal assent, addressed the Parliament and told them, "the 
king willeth that right be done according to the laws and customs of the realm, and that the statutes be put in due execution, that his subjects may have no cause to complain of any wrong or oppression contrary to their just rights and liberties; to the preservation whereof he holds himself in conscience as well obliged, as of his prerogative."

The Commons returned highly incensed with this evasive circumlocution. They forthwith began to assail the favourites of the Crown, and impeached a Dr. Mainwaring who had preached a sermon, which had afterwards been printed by the king's command, in which discourse the right divine of kings to deal as they pleased with their subjects' property on emergencies, whether parliament consented or not, and the duty of passive obedience in the subject, were only and unreservedly maintained. The Commons procured the trial and condemnation of this satellite of arbitrary power, and were proceeding to assail others higher in Charles's councils, when the king's obstinacy at length gave way, and the Petition of Right received the royal assent in the customary form of Norman French, and this second great solemn declaration of the liberties of Englishmen was declared to be the law of the land, amidst the general rejoicings of the nation.

E. S. Creasy, Rise and Progress of the English Constitution. 259.

HANNIS TAYLOR (1889)

Side by side with Eliot, Coke, and Phelips now stood Sir Thomas Wentworth, who did yeoman's service in the popular cause in a great oration in which, after reviewing all the questions in controversy, except those involving the subject of religion, he demanded that there should be no more foreed loans, no more illegal imprisonments, no more compulsory employments abroad, no billeting of soldiers without the assent of the householder, thus ontlining the substance of the great statute, afterwards known as the Petition of Right, which clerived its form from Coke.

HAxis TAYLOR, Origin and Growth of the English Constitution. II. 268. 


\section{RUDOLF VON GNEIST (1889)}

The Petition of Right is treated in later Constitutional State Law as a third Magna Charta, because by it a whole series of glaring administrative abuses are declared illegal in the most unequivocal terms.

Rudolf von Gneist, History of the English Parliament. 253.

\section{GARDINER (1889)}

The Petition of Right is memorable as the first statutory restriction of the powers of the Crown since the accession of the Tudor dynasty. Yet, though the principles laid down in it had the widest possible bearing, its remedies were not intended to apply to all questions which had arisen or might arise between the Crown and the Parliament, but merely to those which had arisen since Charles's accession. Parliament had waived, for the present at least, the consideration of Buckingham's misconduct. It had also waived the consideration of the question of Impositions.

The motives of the Commons in keeping silence on the Impositions were probably twofold. In the first place, they probably wished to deal separately with the new grievances, because in dealing with them they would restrain the King's power to make war without Parliamentary consent. In the second place, they had a Tonnage and Poundage Bill before them. Such a Bill had been introduced into each of the preceding Parliaments, but in each case an early dissolution had hindered its consideration, and the long debates on the Petition of Right now made it impossible to proceed farther with it in the existing session. Yet, for three years the King had been collecting Tonnage and Poundage, just as he collected the Impositions, that is to say, as if he had no need of a Parliamentary grant. The Commons therefore proposed to save the right of Parliament by voting Tonnage and Poundage for a single year, and to discuss the matter at length the following session. When the King refused to accept this compromise they had some difficnlty in ehoosing a counter-move. They were precluded from any argument from ancient statute and preeedent, because the judges in Bates's case had laid down 
the law against them, and they therefore had recourse to the bold assertion that the Petition of Right had settled the question in their favour. Charles answered by proroguing Parliament, and took occasion in so doing to repudiate the doctrine which they advanced.

Sameer R. Gardiner, The Constitutional Documents of the Puritan Revolu. tion. xxiii.-xxiv.

\section{J. K. HOSMER (1890)}

At first, feeble and fitful, the opposition gathered force, dereloping under Charles I. into a stern battle between King and that conservative element of the people who were determined to uphold the ancient ways. The King was forced by the Petition of Right, in 1628 , to admit that his arbitrary course was wrong. It was a profession of the lips, not the heart.

J. K. Hosmer, Anglo-Saxon Freedom. 107. 


\section{Chapter VII}

\section{ENGLISH WRITTEN CONSTITUTIONS (1648-1653)}

\section{SUGGESTIONS}

During the year 1647, Oliver Cromwell tried his best to come to an understanding with King Charles I. A constitutional scheme known as the Heads of the Proposals was drawn up by Ireton, and presented in the name of the army to the King. The wisdom of the Proposals was not accepted, and many of the agitators, finding that the king grew more hostile to Oliver Cromwell and his party, advanced a still more democratic constitution known as the Agreement of the People. This document was presented to Parliament, and an attempt to force it npon the officers was made with threats of mutiny in the army if not accepted. But the immediate action on the part of the King at this time turned the thoughts of the agitators, as well as the whole body of the army, from constitutional law to royal intelligence. The army lost all patience with King and Parliament. The Agreement of the People was set aside, and all thoughts were turned to the attention of the King.

The new Constitution devised by Lambert and embodied in the $I n$ strument of Government, was the document accepted by the council of officers who succeeded the "Little Parliament" as a legislative power. This council was driven by necessity to the step from which they had shrunk before, that of convening a parliament on the reformed basis of representation. The new Constitution was undoubtedly popular. The "Instrument" was taken as the ground work of the new Constitntion, and the Assembly proceeded at once to settle the Government on a parliamentary basis, by discussing the document clanse by clanse.

The two documents here presented were neither of them operative, but they are here inserted because they are early attempts to draw up written constitutions for England, with limitations, checks, and balances; and because their underlying ideas were carried out in some colonial charters and governments, and eventually reappeared in the state and federal constitutions.

For Outlines and Material, see Appendix A. 


\section{DOCUMENTS}

The Agreement of the People (r649)

An Agreement of the People of England, and the TransliterPlaces therewith incorporated, for a secure and ated from present Peace, upon grounds of common Right, The ParliaFreedom, and Sufety. tory of England. (Han-

Having, by our late labours and hazards, made sard, 1808), it appear to the world at how high a rate we value III. 1267our just freedom; and God having so far owned our cause as to deliver the enemies thereof into our hands, we do now hold ourselves bound, in mutual duty to each other, to take the best eare we can for the future, to avoid both the danger of returning into a slavish condition and the chargeable remedy of another war: for as it cannot be imagined that so many of our countrymen would have opposed us in this quarrel if they had understood their own good, so may we hopefully promise to ourselves, that when our common rights and liberties shall be cleared, their endeavours will be dis- liberty, carThe spirit of liberty, carappointed that seek to make themselves our masters. the sword. Since therefore our former oppressions and not-yetended troubles have been oceasioned either by want of frequent national meetings in council, or by the undue or unequal constitution thereof, or by Infrequency rendering those meetings ineffectual, we are fully of Parliaagreed and resolved, God willing, to provide, that in the Tudor hereafter our Representatives be neither left to an Period, but uncertainty for times nor be unequally constituted, amazingly in nor made useless to the ends for which they are creased durintended. In order whereunto we declare and agree, Ing reign of

First. That, to prevent the many inconveniences apparently arising from the long continuance of the same persons in supreme anthority, this present Parliament end and dissolve upon, or before, the last day of $A_{p}$ ril, 1649.

Secondly. That the people of England (being 
at this day very unequally distributed by counties, Note use of cities, and boroughs, for the election of their Repword Repre- resentatives) be indifferently proportioned; and, to sentatives;
later adopted this end, that the Representative of the whole by the Fed- nation shall consist of 400 persons, or not above; eral convention, 1787. and in each county, and the places thereto subjoined, there shall be chosen, to make up the said Representative at all times, the several numbers The list of here mentioned, viz.: . . . and, having first caused districts is this Agreement to be publicly read in the audience here omitted. of the people, shall proceed unto, and regulate and keep peace and order in the elections; and, by poll or otherwise, openly distinguish and judge of the same; and thereof, by certificate or writing under the hands and seals of himself, and six or more of the electors, nominating the person or persons duly elected, shall make a true return into the Parliament Records within twenty-one days after the election, under pain for default thereof, or, for making any false return, to forfeit $£ 100$ to the public use; and also cause indentures to be made, and unchangeably sealed and delivered, between himself and six or more of the said electors, on the one part, and the persons, or each person, elected severally, on the other part, expressing their election of him as a representer of them according to this Agreement, and his acceptance of that trust, and his promise accordingly to perform the same with faithfulness, to the best of his understanding and ability, for the glory of God and good of the people. This course is to hold for the first Representative, which is to provide for the ascertaining of these circumstances in order to future representatives.

Fourthly. That 150 members at least be always

The Legislative Body. present in each sitting of the Representative, at the passing of any law or doing of any act whereby the people are to be bound; saving, that the number of sixty may make a House for debates or resolutions that are preparatory thereunto. 
Fifthly. That each Representative shall, within 20 days after their first meeting, appoint a Council of State for the managing of public affairs, until The Executhe 10 th day after the meeting of the next Representative, unless that next Representative think fit to put an end to that trust sooner. And the same Council to act and proceed therein, according to such instructions and limitations as the Representative shall give, and not otherwise.

Sixthly. 'That in each interval between biennial representatives, the Council of State, in case of Extra Sesimminent danger or extreme necessity, may sum- sions limited mon a Representative to be forthwith chosen, and time. to meet; so as the Session thereof continue not above eighty days; and so as it dissolve at least fifty days before the appointed time for the next biennial Representative; and upon the fiftieth day so preceding it shall dissolve of course, if not otherwise dissolved sooner.

Seventhly. That no member of any Represen-Modern doctative be made either receiver, treasurer, or other trine of sepaofficer, during that employment, saving to be a powers. member of the Council of State.

Eighthly. That the representatives have, and shall be understood to have, the supreme trust in order to the preservation and government of the whole; and that their power extend, without the consent or concurrence of any other person or persons, to the erecting and abolishing of Courts of Justice and public offices, and to the enacting, altering, repealing and declaring of laws, and the highest and final judgment, concerning all natural or civil things, but not concerning things spiritual or evangelical. Provided that, even in things na- Duties of the tural and civil, these six particulars next following Representaare, and shall be, understood to be excepted and respecting reserver from our representatives, viz. 1. We do public affairs. not empower them to impress or constrain any person to serve in foreign war, either by sea or 
land, nor for any military service within the kingdom; save that they may take order for the forming, training, and exercising of the people in a military way, to be in readiness for resisting of foreign invasions, suppressing of sudden insurrections, or for assisting in execution of the laws; and may take order for the employing and conducting of them for those ends; provided that, even in such cases, none be compellable to go out of the county he lives in, if he procure another to serve in his room. 2. That, after the time herein limited for the commencement of the First Representative, none of the people may be at any time questioned for anything said or done in relation to the late wars or public differences, otherwise than in execution or pursuance of the determinations of the present House of Commons, against such as have adhered to the King, or his interest, against the people; and saving that accomptants for public moneys received, shall remain accountable for Perpetuity of the same. 3. That no securities given, or to be the country's given, by the public faith of the nation, nor any obligations. engagements of the public faith for satisfaction of debts and damages, shall be made void or invalid by the next or any future Representatives; except to such ereditors as have, or shall have, justly forfeited the same: and saving, that the next Representative may. confirm or make null, in part or in whole, all gifts of lands, moneys, offices, or otherwise, made by the present Parliament to any member or attendant of either House. 4. That, in any laws hereafter to be made, no person, by virtue of any tenure, grant, charter, patent, degree or birth, shall be privileged from subjection thereto, or from being bound thereby, as well as others.

Dignity of Common Law.
5. That the Representative may not give judgment upon any man's person or estate, where no law hath before provided; some only in calling to account and punishing public officers for abusing or 
failing in their trust. 6. That no Representative may in any wise render up, or give, or take away, any of the foundations of common right, liberty, and safety contained in this Agreement, nor level men's estates, destroy property, or make all things common; and that, in all matters of such fundamental concernment, there shall be a liberty to particular members of the said representatives to enter their dissents from the major vote.

Ninthly. Conceruing religion, we agree as followeth. 1. It is intended that the Christian Reli- Relation of gion be held forth and recommended as the public the govern. profession in this nation, which we desire may, by Christian the grace of God, be reformed to the greatest purity Religion. in doctrine, worship and discipline, according to the Word of God; the instructing the people thereunto in a public way, so it be not compulsive; as also the maintaining of able teachers for that end, and for the confutation or discovering of heresy, error, and whatsoever is contrary to sound doctrine, is allowed to be provided for by our Representatives; the maintenance of which teachers may be out of a public treasury, and, we desire, not by tithes: provided, that Popery or Prelacy be not held forth as the public way or profession in this nation. 2. That, to the public profession so held forth, none be compelled by penalties or otherwise; but only may be endeavoured to be won by sound doctrine, and the example of a good conversation. 3. That such as profess faith in God by Jesus Christ, however differing in judgment from the doctrine, worship or diseipline publicly held forth, as aforesaid, shall not be restrained from, but shall be protected in, the profession of their faith and exercise of religion, according to their consciences, in any place except such as shall be set apart for the public worship; where we provide not for them, unless they have leave, so as they abuse not this liberty to the eivil injury of others, or to act- 
ual disturbance of the public peace on their parts. Exclusion of Nevertheless, it is not intended to be hereby proRoman Cath- vided, that this liberty shall necessarily extend to
olic church.

Popery or Prelacy. 4. That all laws, ordinances, statutes, and clauses in any law, statute, or ordinance to the contrary of the liberty herein provided for, in the two particulars next preceding concerning religion, be, and are hereby, repealed and made void.

Tenthly. It is agreed, that whosoever shall, by

To prevent military despotism. force of arms, lesist the orders of the next or any future Representative (except in case where such Representative shall evidently render up, or give, or take away the foundations of common right, liberty, and safety, contained in this Agreement), he shall forthwith, after his or their such resistance, lose the benefit and protection of the laws, and shall be punishable with death, as an enemy and traitor to the nation. Of the things expressed in this Agreement: the certain ending of this Parliament, as in the first Article; the equal or proportionable distribution of the number of the representers to be elected, as in the second; the certainty of the people's meeting to elect for Representatives biennial, and their freedom in elections; with the certainty of meeting, sitting and ending of Representatives so elected, which are provided for in the third Article; as also the qualifications of persons to elect or be elected, as in the first and second particulars under the third Article; also the certainty of a number for passing a law or preparatory debates, provided for in the fourth Article; the matter of the fifth Article, concerning the Council of State, and of the sixth, concerning the calling, sitting and ending of Representatives extraordinary; also the power of Representatives to be, as in the eighth Article, and limited, as in the six reserves next following the same: likewise the second and third Particulars under the ninth Article concerning 
religion, and the whole matter of the tenth Article; all these we do account and declare to be fundamental to our common right, liberty, and safety: and therefore do both agree thereunto, and resolve to maintain the same, as God shall enable us. The rest of the matters in this Agreement we account to be useful and good for the public; and the particular circumstances of numbers, times, and places, expressed in the several Articles, we account This docunot fundamental; but we find them necessary to be ment was here determined, for the making the here determined, for the making the Agreement Jan. 15, 1649, certain and practicable, aud do hold these most and preconvenient that are here set down; and therefore Rump Pardo positively agree thereunto. By the appointment liament five of his Excellency the Lord-General and his General days later. Council of Officers.

John Rushworth, Sec.

\section{The Instrument of Government ( 1653 )}

The government of the Commonwealth of Eng- Translit.: land, Scotland, and Ireland, and the dominions The Parl. thereunto belonging. Hist. of Eng. (Hansard,

I. That the supreme legislative authority of the 1808), III. Commonwealth of England, Scotland, and Ireland, An attempt and the dominions thereunto belonging, shall be to establish and reside in one Person, and the people assembled an executive in Parliament; the style of which person shall be the on a constiLord Protector of the Commonwealth of England, not a military Scotland, and Ireland. basis.

II. That the exercise of the chief Magistracy The council and the administration of the government over the said countries and dominions, and the people there- pointed by of, shall be in the Lord Protector, assisted with a tector, but council, the number whereof shall not exceed 21 , were irrenor be less than 13 .

III. That all writs, processes, commissions, consent of patents, grants, and other things, which now run in the members. the name and style of the 'Keepers of the Liberty 
of England by Authority of Parliament,' shall run in the name and style of the Lord Protector, from whom, for the future, shall be derived all magistracy and honours in these three nations; and have the power of pardons (except in case of murders and treason) and benefit of all forfeitures for the public use; and shall govern the said countries and dominions in all things by the advice of the council, and according to these presents and the laws.

IV. That the Lord Protector, the Parliament sitCommander- ting, shall dispose and order the militia and forces, in-chief of army and navy by consent of Council.

International relationship with advice of Council.

Note Common Law and Magna Charta.

Triennial summons of a single chamber of Parliament. both by sea and land, for the peace and good of the three nations, by consent of Parliament; and that the Lord Protector, with the advice and consent of the major part of the council, shall dispose and order the militia for the ends aforesaid in the intervals of Parliament.

V. That the Lord Protector, by the advice aforesaid, shall direct in all things concerning the keeping and holding of a good correspondency with foreign kings, princes, and states; and also, with the consent of the major part of the council, have the power of war and peace.

VI. That the laws shall not be altered, suspended, abrogated, or repealed, nor any new law made, nor any tax, charge, or imposition laid upon the people, but by common consent in Parliament, save only as is expressed in the thirtieth article.

VII. That there shall be a Parliament summoned to meet at Westminster upon the third day of September, 1654, and that successively a Parliament shall be summoned once in every third year, to be accounted from the dissolution of the present Parliament.

VIII. That neither the Parliament to be next summoned, nor any successive Parliaments, shall, during the time of five months, to be accounted from the day of their first meeting, be adjourned, prorogued, or dissolved, without their own consent. 
IX. That as well the next as all other successive Parliaments, shall be summoned and elected in manner hereafter expressed; that is to say, the persons to be chosen within England, Wales, the Isles of Jersey, Guernsey, and the town of Berwickupon-Tweed, to sit and serve in Parliament, shall be, and not exceed, the number of four hundred. The persons to be chosen within Scotland, to sit and serve in Parliament, shall be, and not exceed, the number of thirty; and the persons to be chosen to sit in Parliament for Ireland shall be, and not exceed, the number of thirty.

$\mathrm{X}$. That the persons to be elected to sit in Parliament from time to time, for the several counties of England, Wales, the Isles of Jersey and Guerusey, and the town of Berwick-upon-Tweed, and all places within the same respectively, shall be according to the proportions and numbers hereafter expressed: that is to say, ...

The list is omitted.

XI. That the summons to Parliament shall be by The ordiwrit under the Great Seal of England, directed to nances of the sheriffs of the several and respective counties, this docuthe sheriffs of the several and respective counties, ment are the with such alteration as may suit with the present sole attempt, government, to be made by the Lord Protector and his council, which the Chancellor, Keeper, or Commissioners of the Great Seal shall seal, issue, and send abroad by warrant from the Lord Pro- tary frantector. If the Lord Protector shall not give warrant chise, until for issuing of writs of summons for the next Parlia- we reach the ment, before the first of June, 1654, or for the of 1832 . Triennial Parliaments, before the first day of August See Sumin every third year, to be accounted as aforesaid; mons to that then the Chancellor, Keeper, or Commissioners Parliament. of the Great Seal for the time being; shall, without any warrant or direction, within seven days after the said first day of June, 1654, seal, issue, and send abroad writs of summons (changing therein what is to be changed as aforesaid) to the several and respective sheriffs of England, Scotland, and 
Manner of summoning.
Ireland, for summoning the Parliament to meet at Westminster, the third day of September next; and shall likewise, within seven days after the said first day of Angust, in every third year, to be accounted from the dissolution of the precedent Pariiament, seal, issue, and send forth abroad several writs of summous (changing therein what is to be changed) as aforesaid, for summoning the Parliament to meet at Westminster the sixth of November in that third year. That the said several and respective sheriffs, shall, within ten days after the receipt of such writ as aforesaid, cause the same to be proelaimed and published in erery market-town within his county upon the market-days thereof, between twelve and three of the clock; and shall then also publish and declare the certain day of the week and month, for choosing members to serve in Parliament for the body of the said county, according to the tenor of the said writ, which shall be upon Wednesday five weeks after the date of the writ; and shall likewise declare the place where the election shall be made: for which purpose he shall appoint the most convenient place for the whole county to meet in; and shall send precepts for elections to be made in all and every city, town, borongh, or place within his county, where elections are to be made by virtue of these presents, to the Mayor, Sheriff, or other head officer of such city, town, borough, or place, within three days after the receipt of such writ and writs; which the said Mayors, Sheriffs, and officers respectively are to make publication of, and of the certain day for such elections to be madc in the said city, town, or place aforesaid, and to cause elections to be made aceordingly.

XII. That at the day and place of elections, the Sheriff of each county, and the said Mayors, Sheriffs, Bailiffs, and other head officers within their eities, towns, boroughs, and places respectively, shall take 
view of the said elections, and shall make return into the chancery within twenty days after the said elections, of the persons elected by the greater number of electors, under their hands and seals, between him on the one part, and the electors on the other part; wherein shall be contained, that the persons elected shall not have power to alter the government as it is hereby settled in one single person and a Parliament.

XIII. That the Sheriff, who shall wittingly and willingly make any false return, or neglect his duty, Punishment shall ineur the penalty of 2000 marks of lawful for illegalEnglish money; the one moiety to the Lord Pro- ities. tector, and the other moiety to such person as will sue for the same.

XIV. That all and every person and persons, who have aided, advised, assisted, or abetted in any Disloyalty in war against the Parliament, since the first day of England.

January, 1641 (unless they have been since in the service of the Parliament, and given signal testimony of their good affection thereunto) shall be disabled and ineapable to be elected, or to give any vote in the election of any members to serve in the next Parliament, or in the three succeeding Triennial Parliaments.

$\mathrm{XV}$. That all such, who have advised, assisted, or abetted the rebellion of Ireland, shall be disabled Disloyalty in and incapable for ever to be elected, or give any Ireland. vote in the election of any member to serve in Parliament; as also all such who do or shall profess the Roman Cath. Roman Catholic religion. olic religion.

XVI. That all votes and elections given or made contrary, or not according to these qualifications, shall be null and void; and if any person, who is hereby made ineapable, shall give his vote for election of members to serve in Parliament, such person shall lose and forfeit one full year's value of his real estate, and one full third part of his personal estate; one moiety thereof to the Lord Protector, and the 
other moiety to him or them who shall sue for the same.

XVII. That the persons who shall be elected to

Eligibility of representatives.

The Parliament gathered together in 1654 under the mandate of this frame of government brought together for the first time representatives from England, Scotland, and Ireland, in the form in which they sit to-day. serve in Parliament, shall be such (and no other than such) as are persons of known integrity, fearing God, and of good conversation, and being of the age of twenty-one years.

XVIII. That all and every person and persons seised or possessed to his own use, of any estate, real or personal, to the value of $£ 200$, and not within the aforesaid exceptions, shall be capable to elect members to serve in Parliament for counties.

XIX. That the Chancellor, Keeper, or Commissioners of the Great Seal, shall be sworn before they enter into their offices, truly and faithfully to issue forth, and send abroad, writs of summons to Parliament, at the times and in the manner before expressed : and in case of neglect or failure to issue and send abroad writs accordingly, he or they shall for every such offence be guilty of high treason, and suffer the pains and penalties thereof.

$\mathrm{XX}$. That in case writs be not issued out, as is before expressed, but that there be a neglect therein, fifteen days after the time wherein the same ought to be issued out by the Chancellor, Keeper, or Commissioners of the Great Seal ; that then the Parliament shall, as often as such failure shall happen, assemble and be held at Westminster, in the usual place, at the times prefixed, in manner and by the means hereafter expressed; that is to say, that the sheriffs of the several and respective counties, sheriffdoms, cities, boroughs, and places aforesaid, within England, Wales, Scotland, and Ireland, the Chancellor, Masters, and Scholars of the Universities of Oxford and Cambridge, and the Mayor and Bailiffs of the borough of Berwick-upon-Tweed, and other places aforesaid respectively, shall at the several courts and places to be appointed as aforesaid, within thirty days after the said fifteen days, 
cause such members to be chosen for their said several and respective counties, sheriffdoms, universities, cities, boroughs, and places aforesaid, by such persons, and in such manner, as if several and respective writs of summons to Parliament under the Great Seal had issued and been awarded according to the tenor aforesaid: that if the sheriff, or other persons authorized, shall neglect his or their duty herein, that all and every such sheriff and person anthorized as aforesaid, so neglecting lis or their duty, shall, for every such offence, be guilty of high treason, and shall suffer the pains and penalties thereof.

XXI. That the clerk, called the clerk of the Com- Qualificamonwealth in Chancery for the time being, and all tion article. others, who shall afterwards execute that office, to whom the returns shall be made, shall for the next Parliament, and the two succeeding Triennial Parliaments, the next day after such return, certify the names of the several persons so returned, and of the places for which he and they were chosen respectively, unto the Council; who shall peruse the said returns, and examine whether the persons so elected and returned be such as is agreeable to the qualifications, and not disabled to be elected: and that every person and persons being so duly elected, and being approved of by the major part of the Council to be persons not disabled, but qualified as aforesaid, shall be esteemed a member of Parliament, and be admitted to sit in Parliament, and not otherwise.

XXII. That the persons so chosen and assembled in manner aforesaid, or any sixty of them, shall be, and be deemed the Parliament of England, Scotland, and Ireland; and the supreme legislative power to be and reside in the Lord Protector and such Parliament, in manner herein expressed.

XXIII. That the Iord Protector, with the advice of the major part of the Council, shall at any other 
The Protec- time than is before expressed, when the necessities tor's ordain- of the State shall require it, summon Parliaments in lug power. manner before expressed, which shall not be adjourned, prorogued, or dissolved without their own consent, during the first three months of their sitting. And in case of future war with any foreign State, a Parliament shall be forthwith summoned for their advice concerning the same.

XXIV. That all Bills agreed unto by the Parliament, shall be presented to the Lord Protector for Prototype of his consent; and in case he shall not give his conthe Massachusetts Constitution of 1780 and Federal Constitution of 1787.

Method of choosing Council. sent thereto within twenty days after they shall be presented to him, or give satisfaction to the Parliament within the time limited, that then, upon declaration of the Parliament that the Lord Protector hath not consented nor given satisfaction, such Bills shall pass into and become laws, although he shall not give his consent thereunto; provided such Bills contain nothing in them contrary to the matters contained in these presents.

XXV. That Henry Lawrence, Esq., \&c., or any seven of them, shall be a Council for the purposes expressed in this writing: and upon the death or other removal of any of them, the Parliament shall nominate six persons of ability, integrity, and fearing God, for every one that is dead or removed; out of which the major part of the Council shall elect two, and present them to the Lord Protector, of which he shall elect one; and in case the Parliament shall not nominate within twenty days after notice given unto them thereof, the major part of the Council shall nominate three as aforesaid to the Lord Protector, who out of them shall supply the vacancy; and until this choice be made, the remaining part of the Council shall execute as fully in all things, as if their number were full. And in case of corruption, or other miscarriage in any of the Council in their trust, the Parliament shall appoint seven of their number, and the Council six, who, 
together with the Lord Chancellor, Lord Keeper, or Commissioners of the Great Seal for the time being, shall have power to hear and determine such corruption and miscarriage, and to award and inflict punishment, as the nature of the offence shall deserve, which punishment shall not be pardoned or remitted by the Lord Protector; and, in the interval of Parliaments, the major part of the Council, with the consent of the Lord Protector, may, for corruption or other miscarriage as aforesaid, suspend any of their number from the exercise of their trust, if they shall tind it just, until the matter shall be heard and examined as aforesaid.

XXVI. That the Lord Protector and the major part of the Council aforesaid may, at any time before the meeting of the next Parliament, add to the Council such persons as they shall think fit, provided the number of the Council be not made thereby to exceed twenty-one, and the quorum to be proportioned accordingly by the Lord Protector and the major part of the Council.

XXVII. That a constant yearly revenue shall be raised, settled, and established for maintaining of The Protec10,000 horse and dragoons, and 20,000 foot, in torate supEugland, Scotland and Ireland, for the defence and a military security thereof, and also for a convenient number force.

of ships for guarding of the seas; besides $£ 200,000$ per annum for defraying the other necessary charges of administration of justice, and other expenses of the Government, which revenue shall be raised by the customs, and such other ways and means as shall be agreed upon by the Lord Protector and the Council, and shall not be taken away or diminished, nor the way agreed upon for raising the same altered, but by the consent of the Lord Protector and the Parliament.

XXVIII. That the said yearly revenuc shall be System of paid into the public treasury, and shall be issued auditors out for the uses aforesaid. 
XXIX. That in case there shall not be cause hereafter to keep up so great a defence both at land

Lessening power of the Army.

Control of finances in hands of Parliament. or sea, but that there be an abatement made thereof, the money which will be saved thereby shall remain in bank for the public service, and not be employed to any other use but by consent of Parliament, or, in the intervals of Parliament, by the Lord Protector and major part of the Council.

XXX. That the raising of money for defraying the charge of the present extraordinary forces, both at sea and land, in respect of the present wars, shall be by consent of Parliament, and not otherwise: save only that the Lord Protector, with the consent of the major part of the Council, for preventing the disorders and dangers which might otherwise fall out both by sea and land, shall have power, until the meeting of the first Parliament, to raise money for the purposes aforesaid; and also to make laws and ordinances for the peace and welfare of these nations where it shall be necessary, which shall be binding and in force, until order shall be taken in Parliament concerning the same.

XXXI. That the lands, tenements, rents, royalties, jurisdictions and hereditaments which remain yet unsold or undisposed of, by Act or Ordinance of Parliament, belonging to the Commonwealth (except the forests and chases, and the honours and manors belonging to the same; the lands of the rebels in Ireland, lying in the four counties of Dublin, Cork, Kildare, and Carlow; the lands

Forfeitures. forfeited by the people of Scotland in the late wars, and also the lands of Papists and delinquents in England who have not yet compounded), shall be vested in the Lord Protector, to hold, to him and his successors, Lords Protectors of these nations, and shall not be alienated but by consent in Parliament. And all debts, fines, issues, amercements, penalties and profits, certain and casual, due to the. 
Keepers of the liberties of England by authority of Parliament, shall be due to the Lord Protector, and be payable into his public receipt, and shall be recovered and prosecuted in his name.

XXXII. That the office of Lord Protector over these nations shall be elective and not hereditary; Article of and upon the death of the Lord Protector, another Succession: fit peron fit person shall be forthwith elected to succeed him not herediin the Government; which election shall be by the tary ruler. Council, who, immediately upon the death of the Manner of Lord Protector, shall assemble in the Chamber said election. where they usually sit in Council; and, having given notice to all their nembers of the cause of their assembling, shall, being thirteen at least present, proceed to the election; and, before they depart the said Chamber, shall elect a fit person to succeed in the Government, and forthwith cause proclamation thereof to be made in all the three nations as shall be requisite; and the person that they, or the major part of them, shall elect as aforesaid, shall be, and shall be taken to be, Lord Protector over these nations of England, Scotland and Ireland, and the dominions thereto belonging. Provided that none of the children of the late King, nor any of his line or family, be elected to be Lord Protector or other Chief Magistrate over these nations, or any the dominions thereto belonging. And until the aforesaid election be past, the Council shall take care of the Government, and administer in all things as fully as the Lord Protector, or the Lord Protector and Council are enabled to do.

XXXIII. That Oliver Cromwell, Captain-General of the forces of England, Scotland and Ireland, Oliver Cromshall be, and is hereby declared to be, Lord Pro- well, Protectector of the Commonwealth of England, Scotland and Ireland, and the dominions thereto belonging, for his life.

XXXIV. That the Chancellor, Keeper or Commissioners of the Great Seal, the Treasurer, 
Admiral, Chief Governors of Ireland and Scotland, and the Chief Justices of both the Benches, shall be chosen by the approbation of Parliameut; and, in the intervals of Parliament, by the approbation of the major part of the Council, to be afterwards approved by the Parliament.

XXXV. That the Christian religion, as contained Tolerance of in the Scriptures, be held forth and recommended Religion. as the public profession of these nations; and that, as soon as may be, a provision, less subject to scruple and contention, and more certain than the present, be made for the encouragement and maintenance of able and painful teachers, for the instructing the people, and for discovery and confutation of error, hereby, and whatever is contrary to sound doctrine; and until such provision be made, the present maintenance shall not be taken away or impeached.

XXXVI. That to the public profession held forth none shall be compelled by penalties or otherwise; but that endeavours be used to win them by sound doctrine and the example of a good conversation.

XXXVII. That such as profess faith in God by Jesus Christ (though differing in judgment from the doctrine, worship or discipline publicly held forth) shall not be restrained from, but shall be protected in, the profession of the faith and exercise of their religion; so as they abuse not this liberty to the civil injury of others and to the actual disturbance of the public peace on their parts: provided this

Intolerance toward Roman Catholicism.

Spirit of freedom. liberty be not extended to Popery or Prelacy, nor to such as, under the profession of Christ, hold forth and practise licentiousness.

XXXVIII. That all laws, statutes and ordinances, and clauses in any law, statnte or ordinance to the contrary of the aforesaid liberty, shall be esteemed as null and void.

XXXIX. That the Acts and Ordinances of Par- 
liament made for the sale or other disposition of the lands, rents and hereditaments of the late King, Queen, and Prince, of Archbishops and Bishops, \&e., Deans and Chapters, the lands of delinquents and forest-lands, or any of them, or of any other lands, tenements, rents and hereditaments belonging to the Commonwealth, shall nowise be impeached or made invalid, but shall remain good and firm; and that the securities given by Act and Ordinance of Parliament for any sum or sums of money, by any of the said lands, the excise, or any other public revenue; and also the securities given by the public faith of the nation, and the engagement of the public faith for satisfaction of debts and damages, shall remain firm and good, and not be made void and invalid upon any pretence whatsoever.

$\mathrm{XL}$. That the Articles given to or made with the euemy, and afterwards confirmed by Parliament, shall be performed and made good to the persons concerned therein; and that such appeals as were depending in the last Parliament for relief concerning bills of sale of delinquent's estates, may be heard and determined the next Parliament, any thing in this writing or otherwise to the contrary notwithstanding.

XLI. That every successive Lord Protector over these nations shall take and subscribe a solemn oath, in the presence of the Council, and such others as they shall call to them, that he will seek the peace, quiet and welfare of these nations, cause law and justice to be equally administered; and that he will not violate or infringe the matters and things contained in this writing, and in all other things will, to his power and to the best of his understanding, govern these nations according to the laws, statutes and customs thereof.

XIII. That each person of the Council shall, before they enter upon their trust, take and subscribe an oath, that they will be true and faithful 
in their trust, according to the best of their knowledge; and that in the elcction of every successive Lord Protector they shall proceed therein impartially, and do nothing therein for any promise, fear, favour or reward.

\section{CONTEMPORARY EXPOSITION}

OLIVER CROMWELT, (1653)

I suppose the Summons that hath been instrumental to bring you hither gives you well to understand the occasion of your being here. Howbeit, I have something farther to impart to you, which is an Instrument drawn-up by the consent and advice of the principal Officers of the Army; which is a little (as we conceive) more significant than the Letter of the Summons. We have that here to tender you ; and somewhat likewise to say farther for our own exoneration: which we hope may be somewhat farther for your satisfaction. And withal seeing you sit here somewhat uneasily by reason of the scantness of the room and heat of the weather, I shall contract inyself "with respect thereunto. . . .

"But indeed" that is contained in the Paper here in my hand, which will be offered presently to you to read. But having done that, we have done upon such ground of necessity as we have "now" declared, which was not a feigned necessity but a real, — " it did behove us," to the end we might manifest to the world the singleness of our hearts and our integrity who did these things, Not to grasp at the power ourselves, or keep it in military hands, no not for a day; but, as far as God enabled us with strength and ability, to put it into the hands of Proper Persons that might be called from the several parts of the Nation. 'This necessity; and I hope we may say for ourselves, this integrity of concluding to divest the Sword of all power in the Civil Administration, - hath been that that hath moved us to put You to this trouble "of coming hither:" and having done that, truly we think we cannot, with the discharge of our own consciences, but offer somewhat to you on the devolving of the burden on your shonlders. It hath been the practice of others who have, voluntarily and out of a sense of duty, 
divested themselves, and devolved the Government into new hands; I say, it hath been the practice of those that have done so; it hath been practised, and is very consonant to reason, to lay "down," together with their Authority, some Charge "how to employ it," (as we hope we have done), and to press the duty "of employing it well:" concerning which we have a word or two to offer you. . . .

I have only this to add. The affairs of the Nation lying on our hands to be taken care of; and we knowing that both the Affairs at Sea, the Armies in Ireland and Scotland, and the providing of things for the preventing of inconveniences, and the answering of emergencies, did require that there should be no Interruption, but that care ought to be taken for these things ; and foreseeing likewise that before yon could digest yourselves into such a method, both for place, time and other circumstances, as you shall please to proceed in, some time would be required, - which the Commonwealth could not bear in respect to the managing of things: I have, within a week "past," set-up a Council of State, to whom the managing of affairs is committed. Who, I may say, very voluntarily and freely, before they see how the issue of things will be, have engaged themselves in business; eight or nine of them being Members of the House that late was. - I say I did exercise that power which, I thought, was devolved upon me at that time; to the end affairs might not have any interval "or interruption." And now when you are met, it will ask some time for the settling of your affairs and your way. And, "on the other hand," a day cannot be lost, or "left vacant," but they must be in continual Council till you take farther order. So that the whole matter of their consideration also which regards them is at your disposal, as you shall see canse. And therefore I thought it my duty to acquaint you with thus much, to prevent distractions in your way: That things have been thus ordered; that your affairs will "not stop, but" go on, "in the mean. while," - till you see cause to alter this Council; they having no authority or continuance of sitting, except simply until you take farther order.

Carryte, Life of Cromwell, First Speech to the Sixth Parliament. UI. 43, 70 . 


\section{CRITICAL COMMENT}

HALLAM (1827)

They appointed a commission to consider the reformation of the law, in consequence of repeated petitions against many of its inconveniences and abuses; who, though taxed of course with dilatoriness by the ardent innovators, suggested many useful improvements, several of which have been adopted in more regular times, though with too cautious delay. They proceeded rather slowly and reluctantly to frame a scheme for future parliaments; and resolved that they should consist of 400 , to be chosen in due proportion by the several counties, nearly upon the model suggested by Lilburne, and afterwards carried into effect by Cromwell. . . .

It was now the deep policy of Cromwell to render himself the sole refuge of those who valued the laws, or the regular ecclesiastical ministry, or their own estates, all in peril from the mad enthusiasts who were in hopes to prevail. These he had admitted into that motley convention of one hundred and twenty persons, sometimes called Barebone's parliament, but more commonly the little parliament, on whom his council of officers pretended to devolve the government, mingling them with a sufficient proportion of a superior class whom he could direct.

Henry Hallam, The Constitutional History of Ëngland. II. 241, 242, 243.

\section{MACAULAY (1849)}

The name of king was hateful to the soldiers. Some of them were indeed unwilling to see the administration in the hands of any single person. The great majority, however, were disposed to support their general as elective first magis. trate of a commonwealth, against all factions which might resist his authority; but they would not consent that he shonld assume the regal title, or that the dignity, which was the just reward of his personal merit, should be declared hereditary in his family. All that was left to him was, to give to the new republic a constitution as like the constitution of the old monarchy as the army would bear. ... 
His plan bore from the first, a considerable resemblance to the old English constitution; but in a few years, he thought it safe to proceed further, and to restore almost every part of the ancient system under new names and forms. The title of king was not revived, but the kingly prerogatives were intrusted to a lord high protector. The sovereign was called, not His Majesty, but His Highness. He was not crowned and anointed in Westminster Abbey, but was solemnly enthroned, girt with a sword of state, clad in a robe of purple, and presented with a rich Bible, in Westminster Hall. His oflice was not deelared hereditary; but he was permitted to name his successor.

Thomas Babivgtox Macaulay, History of England. I. 104.

\section{BAGEHOT (1872)}

The second period of the British Constitution begins with the accession of the House of Tudor, and goes down to 1688; it is in substance the history of the growth, development, and gradually acquired supremacy of the new great council. . . . The steps were many, but the energy was one - the growth of the English middle-class, using that word in its most inclusive sense, and its animation under the influence of Protestantism. .. A still stronger anti-Papal spirit entered into the middle sort of Englishmen, and added to that foree, fibre, and substance which they have never wanted, an ideal warmth and fervour which they have almost always wanted. Hence the saying that Cromwell founded the English Constitution. Of course, in seeming, Cromwell's work died with him; his dynasty was rejected, his republic cast aside; but the spirit which culminated in him never sank again, never ceased to be a potent, though often latent and volcanic force in the country.

Walter Bagenot, English Constitution. 282.

\section{J. R. GREEN (1874)}

The dissolution of the Convention replaced matters in the state in which its assembly had found them; but there was still the same general anxiety to substitute some sort of legal rule for the power of the sword. The Convention had named 
during its session a fresh Council of State, and this body at once drew up, under the name of the Instrument of Government, a remarkable Constitution, which was adopted by the Council of Officers. They were driven by necessity to the step from which they had shrunk before, that of convening a Parliament on the reformed basis of representation, though such a basis had no legal sanction. The House was to consist of four hundred members from England, thirty from Scotland, and thirty from Ireland. The seats hitherto assigned to small and rotten boroughs were transferred to larger constituencies, and for the most part to counties. All special rights of voting in the election of members were abolished, and replaced by a general right of suffrage, based on the possession of real or personal property to the value of two hundred pounds. Catholics and "Malignants" as those who had fought for the King were called, were excluded for the while from the franchise. Constitutionally all further organization of the form of government should have been left to this Assembly; but the dread of disorder during the interval of its election, as well as a longing for "settlement," drove the Council to complete their work by pressing the office of "Protector" upon Cromwell. ... The powers of the new Protector indeed were strictly limited. Though the members of the Council were originally named by him, each member was irremovable save by consent of the rest: their advice was necessary in all foreign affairs, their consent in matters of peace and war, their approval in nominations to the great offices of state, or the disposal of the military or civil power. With this body too lay the choice of all future Protectors. To the administrative check of the Council was added the political check of the Parliament. Three years at the most were to elapse between the assembling of one Parliameut and another. Laws could not be made, nor taxes imposed but by its authority, and after the lapse of twenty days the statutes it passed became laws even if the Protector's assent was refused to them. The new Constitution was undoubtedly popular; and the promise of a real Parliament in a few months covered the want of any legal character in the new rule. The Government was generally accepted as a provisional one, which could only acquire legal authority from the ratifica- 
tion of its acts in the coming session; and the desire to settle it on such a Parliamentary basis was universal among the members of the new Assembly which met in the autumn at Westminster.

J. R. Green, Short History of the English People. 585, 586.

\section{TASWELL-LANGMEAD (1879)}

In this connection it has been observed, that the significance of the Commonwealth consists before all else in the fact that England for the first time in its history showed the world what a strong resolute government, freed from the fetters of the mediæval parliamentary State, and a government which, in respect of broad views and absence of prejudice, was far in advance of its time, could achieve both without and within.

T. P. Taswell-Laxgmead, English Constitutional History. 508.

HANNIS TAYLOR (1889)

As early as October, 1647, the levellers had embodied their new conception of government in the draft of a constitution entitled " The Agreement of the People," which proposed, first, that the constituencies should be "more indifferently proportioned according to the number of inhabitants;" second, that the existing parliament should be dissolved on September 30,1648 ; third, that all future parliaments should be triennial ; fourth, that a single elected chamber should be supreme in all things not " expressly or impliedly reserved by the represented to themselves." This prototype of all constitutions, state and federal, as they exist to-day in the United States, was to draw its authority from a direct acceptance by the people, who reserved to themselves, by express constitutional limitations upon the powers granted, certain rights, among which the agreement pointedly named the absolute right to religious liberty and due process of law. . . .

The scheme of government embodied in the "Instrument" undertook to impose a twofold limitation upon the powers of the chief of state, whom it designated as lord protector. The supreme executive power was vested in him, acting with the advice of a council of state whose members, though originally 
appointed by him, were irremovable save by the consent of the rest. With the advice of the council the protector could treat with foreign states, with its consent he conld make peace and war, while in it alone was vested the power to choose all future protectors. The supreme legislative power was vested in the protector, and a parliament consisting of a single chamber to be composed of four hundred members from England, thirty from Scotland, and thirty from Ireland, according to the plan formulated by Vane at the close of the Long Parliament, but which that body failed to enact into law. No statutes were to be passed nor taxes imposed withont the consent of this assembly, and all of its enactments were to become law within twenty days even without the protector's consent, unless he conld persuade the house of the reasonableness of his objections. It was not to be adjourned, prorogued, or dissolved without its own consent within the first five months after its meeting, and a new parliament was to be assembled every three years. Every person possessed of real or personal property of the value of two hundred pounds had the right to rote for members, and all were eligible as electors or as members except malignants, delinquents, and Roman Catholics. Religious liberty was guaranteed to all Christians except prelatists, papists, and those who taught licentiousness under the name of religion. As the new chamber thus provided for was not to meet until the third of the following September, the protector was authorized in the mean time to raise all money necessary for the public service, and to make ordinances, which should have the force of law until the subjects embraced in them could be provided for by parliamentary enactments. Under this provision, which gave to the protector a wide scope for the exercise of his administrative genins, he issned before the parliament met sixty-four ordinances, which embraced all the more important questions then pressing for solution in church and state.

Handis Taylor, The Origin and Growth of the English Constitution. II. $341-349$.

S. R. GARDINER (1889)

On January 15, 1649, whilst the King's fate was still in suspense, the Council of the Army set forth a document known as 
the Agreement of the People. It was a sketch of a written Constitution for a Republican Government based on the Heads of the Proposals [see this paper in Gardiner's Constitutional Documents, page 232], omitting everything that had reference to the King. The Heads of the Proposals had contemplated the retention of the Royal authority in some shape or another, and had been content to look for security to Acts of Parliament, because, though every Act was capable of being repealed, it could not be repealed without the consent both of the King and the Houses, and the Houses might be trusted to refuse their consent to the repeal of any Act which checked the despotism of the King; whilst the King could be trusted to refuse his consent to the repeal of any Act which checked the despotism of the Houses. With the disappearance of Royalty the situation was altered. The despotism of Parliament was the chief danger to be feared, and there was no possibility of averting this by Acts of the Parliament itself. Naturally, therefore, arose the idea of a written Constitution, which the Parliament itself would be incompetent to violate. According to the proposed scheme, the existing Parliament was to be dissolved on April 30,1649 . After this there was to be a biennial Parliament without a House of Lords, a redistribution of seats, and a rating franchise. For seven years all who had adhered to the King were to be deprived of their votes, and during the first and second Parliaments only those who had by contributions or by personal service assisted the Parliament, or who had refrained from abetting certain combinations against Parliament, were to be capable of being elected, whilst those who had actually supported the King in the war were to be excluded for fourteen years. Further, no official was to be elected. There was to be a Council for " managing public affairs." Further, six particulars were set down with which Parliament could not meddle, all laws made on those subjects having no binding force.

As to religion, there was to be a public profession of the Christian religion " reformed to the greatest purity of doctrine," and the clergy were to be maintained " out of a public treasury," but " not by tithes." This public religion was not to be "Popery or Prelacy." No one was to be compelled to conformity, but all religions which did not create disturbances were 
to be tolerated. It was not, however, to be understood "that this liberty shall necessarily extend to Popery or Prelacy," a clause, the meaning of which is not elear, but which was probably intended to leave the question open to Parliament to decide. The Article on Religion was, like the six reserved particulars, to be out of the power of Parliament to modify or repeal.

The idea of reserving certain points from Parliamentary action was one which was subsequently adopted in the American Constitution, with this important difference, that the American Constitution left a way open by which any possible change could be effected by consulting the nation; whilst the Agreement of the People provided no way in which any change in the reserved powers could be made at all. In short, the founders of the American Constitution understood that it was useless to attempt to bind a nation in perpetuity, whilst the English Council of the Army either did not understand it, or distrusted the nation too far to make provision for what they knew must come in time. ...

That the execution of the King made the difficulties in the way of the establishment of a Republic greater than they had been, it is impossible to deny; but the main difficulties would have existed even if the King had been deposed instead of executed. 'There are two foundations upon which government must rest if it is to be secure, the traditional continuity which is derived from the force of habit, and the national support which is derived from the force of will. The Agreement of the People swept the first aside, and only trusted the latter to a very limited extent.

The Instrument of Government was intended to suit a Constitutional Government carried on by a Protector and a single House. The Protector therefore stepped into the place of the King, and there were therefore clauses inserted to define and check the power of the Protector, which may fitly be compared with those of the Heads of the Proposals. The main difference lay in this, that the Heads of the Proposals were intended to check a King who, at least for some time to come, was to be regarded as hostile to the Parliament, whereas the Instrument of Government was drawn up with the sanction of the Protector, and therefore took it for granted that the Protector was 
not to be guarded against as a possible enemy. His power however was to be limited first by his Council of State, and secondly by Parliament.

Parliament was to be elected and to meet, not as according to the Agreement of the People, once in two, but once in three years, and to remain in session at least five months. It was to be elected in aceordance with a scheme for the redistribution of seats based on that set forth in the Agreement of the People, the Protector and Council having leave to establish constituencies in Scotland and Ireland, which were now to send members to the Parliament of Westminster. It was the first attempt at a parliamentary union between the three countries carried out at a time when such a union was only possible, because two of the countries had been conquered by one. Instead of the old freehold franchise, or of the rating franchise of the Agreement of the People, there was the franchise in the counties to be given to the possessors of real or personal estate to the value of $£ 200$. As nothing was said about the boroughs, the right of election would remain in those who had it under the Monarchy, that is to say, it would vary according to the custom of each borough. In those boroughs in which the corporations elected, the feeling by this time would be likely to be anti-Royalist. The disqualification elauses were less stringently drawn than in the Agreement of the People, but all who had abetted the King in the war were to be deprived of their votes at the first election and of the right of sitting in the first four Parliaments. Those who had abetted the Rebellion in Ireland, or were Roman Catholics, were permanently disqualified from sitting or voting. . . .

'The clauses relating to the power of Parliament in matters of finance seem to have been modelled on the old notion that " the King was to live of his own" in ordinary times. A constant yearly revenue was to be raised for supporting an army of 30,000 men - now regarded as a permanent charge - and for a fleet sufficient to guard the seas as well as $£ 200,000$ for the domestic administration. The total amount, and the sourees of the necessary taxation, were to be settled by the Protector and Council; Parliament baving no right to diminish it without the consent of the Protector. With respect to 
war expenses, they were to be met by votes of Parliament, except that in the intervals of Parliament the Protector and Council might raise money to meet sudden emergencies from war till the Parliament could meet, which the Protector and Council were bound to summon for an extraordinary session in such an emergency. ...

The functions of the Council were of considerable importance. In all important matters the Protector had to act by its advice, and when Parliament was not in session it was to join him in passing Ordinances which were to be obeyed until in the next session Parliament either confirmed them or disallowed them. On the death of the Protector it was the Council which was to elect his successor. ...

The Instrument of Government suffered not only under the vice of ignoring the probable necessity of its amendment in the future, but also under the vice of having no support either in traditional loyalty nor in national sanction. If, however, we pass over these all-important faults, and discuss it from the purely constitutional point of view, it is impossible not to be struck with the ability of its framers, even if we pronounce their work to be not entirely satisfactory. It bears the stamp of an intention to steer a middle course between the despotism of a " single person " and the despotism of a "single House." Parliament had supreme rights of legislation, and the Protector was not only sworn to administer the law, but every illegal act would come before the courts of law for condemnation. Parliament, too, had the right of disapproving the nominations to the principal ministerial offices, and of voting money for conducting operations in time of war. Where it fell short of the powers of modern Parliaments was in its inability to control administrative acts, and in its powerlessness to refuse supplies for the carrying on of the government in time of peace. A modern Parliament can exercise these powers with safety, because if it uses them foolishly a government can dissolve it and appeal to the nation, whereas Cromwell, who was but the head of a party in the minority, and whose real strengtl rested on the army, did not venture to appeal to the nation at large, or eren to appeal too frequently to the constituencies who were to elect his Parliament. 
The real constitutional safeguard was intended to be in the Council of State. Ultimately, after the death of the Councillors named in the Instrument, the Council of State would indirectly represent the Parliament, as no one would have a place on it whose name had not been one of six presented by Parliament. In the Council of State, the Protector would be in much the same position as a modern Prime Minister in his Cabinet, except that each member of the Council held his position for life, whereas a modern Prime Minister can obtain the resignation of any member of the Cabinet with whom he is in strong disagreement. On the other hand, the greater part of the members of a modern Cabinet are heads of executive departments, and thus have a certain independent position of their own. In some respects indeed, the relations between the Protector and the Council were more like those between an American President and the Senate in executive session, than those between an English Prime Minister and the Cabinet. The members of the American Senate are entirely independent of the President, as the members of the Council of the Protectorate were entirely independent of the Protector when once they had been chosen. On the other hand, the two bodies differed in a most important particular. The tendency of the American Senate, which is never officially brought into personal contact with the President, is to be antagonistic to the President. The tendency of the Council of State, which was in daily contact with the Protector, was to work with him instead of against him. It was not, however, in consequence of its merits or demerits as a constitutional settlement that the Instrument of Government failed. It broke down because the first Parliament summoned under it refused to acknowledge its binding force, and claimed to be a constituent as well as a legislative body.

S. R. GArdiner, Introduction to Constitutional Documents of the Puritan Revolution. lii. lix.

\section{J. K. HOSMER (1890)}

On the 20th, the agreement of the People was formally presented. . . . In 1647, Ireton, to whom the bold and masterly elaboration was for the most part due, had not been ready for so radical a step, and had left the council abruptly, as we have 
seen, at the suggestion of laying by the King; but in the Army now, rank and file and chiefs stood together. The paper consisted of ten articles. . . Except the 8th article, relating to the religious establishment, which, juclged by modern ideas, is narrow, there is nothing here not most thoroughly reasouable. Ireton himself, like Cromwell and Vane, was ready for the broadest toleration, inclucling even Jews, infidels, and Pagans ; but even in the Rump there were prejudices that must be humoured. On the 6th of February it was resolved: "That the House of Peers in Parliament is useless and dangerous, and ought to be abolished," and on the following day, " that the office of the King. . . . is unnecessary, burdensome, and dangerous to the liberty, safety, and public interest of the People of this nation, and therefore ought to be abolished." The old order was thus completely swept away, and England was a Republic. The English reforms already gained in the nineteenth century, and still in progress at the present hour, were all anticipated: all too, that is most essential in the American system had been formulated.

Thus we see that popular government, the heritage from the ancient Saxon time, seemed likely to have in the days of the Ironsides a most complete and memorable revival. It is to be noticed that it came about as something into which people were forced, rather than something which they voluntarily embraced. Eliot, Pym, and Hampden never conceived for England of a polity in which King and Lords should be swept away. It was the rank and file of the Army, the plain people, the tradesmen of the towns; or rather, since the towns in great majority became Presbyterian, it was the small farmers, the yeomen, from whom proceeded the first assertion of a complete right to selfgoverument. Their own leaders at first held back, in some cases denouncing so thorough a sweep. At last, however, Cromwell, Ireton, Vane, and Milton stood thoroughly with the men, - justifying themselves in their course by the belief that they undertook no new thing, but only restored the essentials of that most ancient freedom that had been so deeply overlaid.

James K. Hosmer, A Short History of Anglo-Saxon Freedom. 152-155. 
At the eulminating point of the Puritan Revolution, when Cromwell, swept on by the democratic movement, is compelled to follow it if he would become its master, a curious constitutional project is seen coming to the surface. This is the "Agreement of the People" presented by the army to the House of Commons, for its approval and eventual subınission to the people. The idea of its anthors, clearly stated in the document itself, and discussed in the pamphlets of the day, was the establishment of a supreme law, placed beyond the reach of Parliament, defining the powers of that body and expressly declaring the rights which the nation reserved to itself and which no authority might touch with impunity. 'This popular compaet was to reeeive the personal adhesion of the eitizens, according to a special procedure therein provided. Its promulgation depended upon its acceptance by the people.

Cinarles Borgenud, Adoption and Amendment of Constitutions in Europe and America, translated by C. D. Hazen. 5-6.

\section{BORGEAUD (1894)}

This manifesto contains the outline of a complete constitution. When we read it and summarize the demands it contains, we are astounded to find that it is nearly two centuries and a half old. The principles which it lays down are, for the most part, the very principles which contemporary democraey las first sneceeded in establishing, or is stili demanding. The sovereignty of the people: supreme power vested in a single representative assembly; the executive entrusted by an assembly to a couneil of state, elected for the term of one legislature; biennial parliaments; equitable and proportionate distribution of seats: extension of the right of roting, and of election to all citizens dwelling in the electoral districts who are of full age, and neither hired servants nor in receipt of relief : the toleration of all forms of Christianity : the suppression of state interferenee in ehurch government; the limitation of the powers of the representative assembly, by fundamental laws embodied in the eonstitution, espeeially with regard to the civil liberties guaranteed to citizens - these are the principles 
proclaimed by the English democrats in January, 1648-49. -.. This document bears the significant title of "An Agreement of the People of England." It was presented to Parliament, not in order that Parliament might publish it of its own authority, but that it might approve it and submit it to the nation. . . . It was a real constitutional Charter, founded on the direct acceptance of the people, and placed above the reach of the representative Assembly - a constitution in the sense in which the word is understood by the democracies of the United States and Switzerland to-day.

When the roll containing the Agreement of the People was presented to the House of Commons, the address was listened to with all the respect due to the rank of those who bore it, and a vote of thanks was passed with great solemnity. The reading of the Agreement itself, however, was put off to a more convenient season. Business of the greatest importance was then occupying the minds of some of its members. On that very day began the trial of the King.

It is remarkable, however, that certain reforms which had formerly been demanded by the democratic party, or brought forward in the Agreement of the People, were carried out during the Protectorate; for example, the judicial reforms and the reforms in the system of parliamentary representation.

The Instrument of Government which was elaborated in 1653 by the Council of Officers, was a written Constitution, the first, and down to the present time the only one ever possessed by modern England.

Charles Borgenud, Rise of Modern Democracy in Old and New England, translated by Mrs. Birkbeck Hill. 38-98.

\section{RANSOME (1895)}

Three days later, a new constitution, devised by Lambert and embodied in the Instrument of Government, was accepted by the council of officers. In it the executive and legislative power's were distributed between a Protector, a council of state, and a parliament. Cromwell was named Protector, and was to be general by sea and land. He was, however, to decide questions of war and peace by the advice of the council 
of state, and in case of war, parliament was to be immediately summoned. The members of the council of state were also named in the instrument: and the chief were Lambert, Desborough, Montague, Skippon, Antony Ashley Cooper, and six others. On the death of any of these, the vacancy was to be filled up by the Protector from a list of six names chosen by parliament. All legislative power was reserved to parliament, but the Protector might suspend the coming into operation of any act for twenty days. Parliaments were to be elected by the new constituencies profosed by the Long Parliament, in accord with the Agreement of the People. They were to be held every third year; but no parliament was to be dissolved till it had sat five months. By these arrangements it was hoped to combine the freedom of republican institutions with the practical efficiency of a single sovereign acting through a cabinet. In reality, except when parliament was sitting, it gave almost unlimited power to the Protector. Cromwell at once accepted the post of Protector, and was solemnly inaugurated in Westminster Hall, Lambert taking the leading share in the ceremony.

Cyril Ransome, An Advanced History of England. 600.

\section{MEDLEY (1898)}

From 1642 to 1660 the English Constitution was practically in abeyance; but the expedients which were evoked to fill the void, formed no unimportant element in the future development of the constitution. For, in the first place, the period of the Commonwealth was distinguished by an attempt to change the whole current of English history. As things have worked themselves out, we have a constitution which contains no fundamental laws unalterable by the three Estates in Parliament assembled, but leaves that body the legal sovereign with control of the executive. But had the constitutions projected under the Commonwealth been permanent, the development of our system would have been liampererl, if not checked, by fundamental laws, and the written constitution would have been sovereign instead of Parliament; while the executive and legislature would have existed independently of each other, as in the United States at the present day. In the second place, 
Cromwell was perhaps chiefly hindered by his conservatism. For he fell back on old expedients, and tried, as far as might be, to reproduce the old constitution without those links of historical association which had bound its several parts together, and with that balance of powers which his training in the ranks of the parliamentary party had led him to regard as the ideal. Thus the Instrument of Government set up an executive of a Protector and Council with co-ordinate authority, and a Parliament of one chamber independent of the Council, unable on the one hand to alter the constitution, and on the other hand to be itself adjourned or dissolved for five months without its own consent.

Dudeey Julies Medeey, A Student's Manual of English Constitutional History. 305-306. 


\section{Chapter VIII}

\section{HABEAS CORPUS ACT (1679)}

\section{SUGGESTIONS}

ThE document for the Habeas Corpus Act is intituled "an act for the better securing of the liberty of the subject and for prevention of imprisonments beyond the seas." Various attempts have been made unsuccessfully to obtain the passage of two Bills, one to give a more expeditious use of the writs of Habeas Corpus in Criminal matters the other to prevent imprisonment in jails beyond the seas.

The old principle of relief from arbitrary arrest laid down in Magna Charta, and applied throughout the succeeding constitutions, always lacked a short and easy process of establishing the fact of illegal detention. At length in 1679 this famous act was passed; although defective in the promises as to bail and common law and falsehood, this statute stands as one of the most important landmarks of human liberty. It should be studied in its relation to the growth of the liberty of the subject.

For Outlines and Material, see Appendix A.

\section{DOCUMENT}

\section{Habeas Corpus Act (1679)}

Extracts from the Provisions of the Statute, $31^{\circ}$ Car. II. c. 2.

1. That on complaint and request in writing by or Transliteraon behalf of any person committed and charged with tion from any crime (unless committed for treason or felony of the Realm, expressed in the warrant; or as accessory, or on sus- V, $935-938$. picion of heing accessory, before the fact, to any dix (B) petit-treason or felony; or upon suspieion of such for full text. petit-treason or felony, plainly expressed in the war- Note Magna rant; or unless he is convicted or charged in execu-39-40. tion by legal process), the lord chancellor or any of the twelve judges, in vacation, upon viewing a 
copy of the warrant, or affidarit that a copy is denied, shall (unless the party has neglected for two

There are various kinds made use of in England; and the same, and still others, in the United States.

Blackstone counts this " high prerogative." terms to apply to any court for his enlargement) award a habeas corpus for such prisoner, returnable immediately before himself or any other of the judges; and upon the return made shall discharge the party, if bailable, upon giving security to appear and answer to the accusation in the proper court of judicature.

2. That such writs shall be endorsed, as granted in pursuance of this act, and signed by the person awarding them.

3. That the writ shall be returned and the prisoner a brought up, within a limited time according to the distance, not exceeding in any case twenty days.

4. That officers and keepers neglecting to make due returns, or not delivering to the prisoner or his agent within six hours after demand a copy of the warrant of commitment, or shifting the custody of a prisoner from one to another, without sufficient reason or authority, (specified in the act,) shall for the first offence forfeit $£ 100$ and for the second offence $£ 200$ to the party grieved, and be disabled to hold his office.

5. That no person, once delivered by habeas corpus, shall be recommitted for the same offence, on penalty of $£ 500$.

6. That every person committed for treason or felony shall, if he requires it the first week of the next term, or the first day of the next session of oyer and terminer, be indicted in that term or session, or else armitted to bail; unless the king's witnesses cannot be produced at that time; and if acquitted, or if not indicted and tried in the second term or session, he shall be discharged from his imprisonment for such imputed offence; but that no person, after the assizes shall be open for the county in which he is detained, shall be removed by habeas corpus, till after the assizes are ended; but shall be left to the justice of the judges of assize. 
7. That any sueh prisoner may move for and obtain his habeas corpus, as well out of the chancery, or exchequer, as out of the king's bench or common pleas; and the lord chancellor or judges denying the same, on sight of the warrant or oath that the same is refused, forfeit severally to the party grieved the sum of $£ 500$.

8. 'That this writ of habeas corpus shall run This act, as into the counties palatine, cinque ports, and other expressed in privileged places, and the islands of Jersey and was so often Guernsey.

9. That no inhabitant of England (except per- $\begin{aligned} & \text { reign of } \\ & \text { Charles I. }\end{aligned}$ sons contracting, or convicts praying, to be trans- that it ported; or having committed some capital offence brought in the place to which they are sent) shall be sent parliamenprisoner to Scotland, Ireland, Jersey, Guernsey, or tary inquiry any places beyond the seas, within or without the Petition of king's dominions; on pain that the party commit- Right, 1628. ting, his advisers, aiders, and assistants, shall forfeit Broken in to the party grieved a sum not less than $£ 500$ to portationbe recovererl with treble costs; shall be disabled to Act in reign bear any office of trust or profit; shall incur the of George penalties of praenunire; and shall be incapable of the king's pardon.

\section{CONTEMPORARY EXPOSITION}

BISHOP BURNET (1724)

It was carried by an odd artifice in the House of Lords. Lord Grey and Lord Norris were named to be the tellers. Lord Nolris being a man subject to vapours, was not at all times attentive to what he was doing, so, a very fat lord coming in, Lord Grey counted him for ten as a jest at first, but seeing Lord Norris had not observed it, he went on with this misreckoning of ten; so it was reported to the house, and declared that they who were for the bill were the majority, though it indeed went on the other side; and by this means the bill was past.

Gilbert Burnet, History of His Own Time. I. 485. 


\section{CRITICAL COMMENT}

BLACKSTONE'S COMMENTARIES (1765)

The oppression of an obscure individual gave birth to the famous habeas corpus act (31 Car. II. c. 2) which is frequently cousidered as another mugna carta of the kingdom; and by consequence and analogy has also in snbsequent times reduced the general method of proceeding on these writs ... to the true standard of law and liberty.

Sir Wm. Blackstone, Commentaries on the Laws of England. B. III. 135-136.

\section{CREASY (1859)}

The Habeas Corpus Act also, which was passed in this reign (31 Car. II. c. 2), is of great constitutional value, though it by no means introduced any new principle into our system, or formed any such epoch in the acquisition of the national liberties as some writers represent. But it made the remedies against arbitrary imprisonment short, certain, and obtainable at all times and in all cases. . . .

These enactments, and especially the Habeas Corpus Act, make the name of Charles II. figure creditably in our statutebook, and there is one judicial decision of this reign which established a constitutional principle of the highest value, or rather which put an end to a long-continued abuse of the most perilous character.

E. S. Creasy, Rise and Progress of the English Constitution. $269,272$.

\section{R. C. HURD (1877)}

It was not to bestow an inmunity from arbitrary imprisonment, which is abundantly provided in Magna Carta (if indeed it is not much more ancient), that the statute of Charles II. was enacted; but to cut off the abuses by which the government's lust of power, and its servile subtlety of crown lawyers, had impaired so fundamental a privilege.

Rollin C. Hund, Right of Personal Liberty.

84. 


\section{PATERSON (1877)}

On May 27, 1679, the Habeas Corpus Act passed, and, after the lapse of two centuries, it has been found by experience to have made the machinery revolve so promptly and cut so clearly into the marrow of all the mischiefs attending the possession of might, regardless of right, that no king or minister, led away with the dream of power, has since sought seriously to baftle or disable it. . . It is now a familiar code, and represents a whole armoury of strength, for every line and syllable of which each citizen would fight to the last, as for his housebold gods. Holt said every man should be concerned for Magna Charta. And the Habeas Corpus Act is only a natural sequel and development of Magna Charta. No dictator, whether single-handed or hydra-headed, can long breathe the same air with those who have caught the secret of its power. It appeals to the first principles of security, and to the law of nature, if any such there be. Its whole essence is nothing else than this. Every human being, who is not charged with or convicted of a known crime, is entitled to personal liberty.

James Paterson, Liberty of the Subject, Security of the Person. II. 207-8.

\section{TASWELL-LANGMEAD (1879)}

It was subject, however, to three defects. (1) It fixed no limit on the amount of bail which might be demanded. (2) It only applied to commitments on Criminal or supposed Criminal charges; all other cases of unjust imprisonment being left to the habeas corpus at Cominon Law as it subsisted before this enactment. (3) It did not guard against falsehoods in the return. The first of these defects was remedied in 1689 , by the Bill of Rights, which declared " that excessive bail ought not to be required." The other two (notwithstanding a serious attempt in 1757 to render the habeas corpus at Common Law more efficient) subsisted down to the year 1816 when they were at length removed by 'An Act for more effectually securing the liberty of the subject.' (56 Geo. III. c. 100.)

T. P. Tagwell-Lasgmean, English Constitutional History. 521. 
The right to the writ of Habeas Corpus existed at common law long before the passing in 1679 of the celebrated Habeas Corpus Act (31 Car. II. cap. 2), and you may wonder how it has happened that this and the subsequent Act (56 Geo. III. cap. 100) are treated and (for practical purposes) rightly treated, as the basis on which rests an Englishman's security for the enjoyment of his personal freedom. The explanation is, that prior to 1679 the right to the writ was often, under various pleas and excuses, made of no effect. The aim of the Habeas Corpus Act has been to meet all the devices by which the effect of the writ can be evaded, either on the part of the judges, who brought to issue the same, and if necessary discharge the prisoner, or on the part of the gaoler or the person who has the prisoner in custody. The earlier Act of Charles the Second applies to persons imprisoned on a charge of crime. 'The later Act of George the Third applies to persons deprived of their liberty otherwise than on a criminal accusation.

$\Lambda$ Lbert V. Dicex, Introduction to the Study of the Law of the Constitution. $207,208$.

\section{MAY (1887)}

The writ of Habeas Corpus is unquestionably the first security of civil liberty. It brings to light the cause of every imprisonment, approves its lawfulness, or liberates the prisoner. It exacts obedience from the highest courts; Parliament itself submits to its anthority. No right is more justly valued. It protects the subject from unfounded suspicions, from the aggressions of power, and from abuses in the administration of justice. Yet this protective law, which gives every man security and confidence in times of tranquillity, has been suspended, again and again, in periods of public danger or apprehension. Rarely, however, has this been suffered without jealousy, hesitation, and remonstrance; and whenever the perils of the state have been held sufficient to warrant this sacrifice of personal liberty, no minister or magistrate has been suffered to tamper with the law at his discretion. Parliament alone, convinced of the exigency of each occasion, has sus- 
peurled, for a time, the rights of individuals, in the interests of the state.

Sin Thomas Erskine Max, The Constitutional History of England. II. $252,253$.

\section{HANNIS TAYLOR (1889)}

To put an end forever to every device, plea, or excuse by which the right to the actual benefits of the writ had been formerly made abortive, was finally passed the Habeas Corpus Act of 1679 , the essence of which is that the chancellor and all of the judges are charged with the duty upon a proper application to direct the writ even he privileged places, including the islands of Jersey and Guernsey, requiring any person who is imprisoned to be actually and speedily brought before the court, together with the cause of the imprisonment, to the end that such court may either set him free, bail him, or remand him for a speedy trial, as justice may require.

Hansis Taylor, Origin and Growth of the English Constitution. II. 382. 


\section{Chapter IX}

\section{THE BILL OF RIGHTS (1689)}

\section{SUGGESTIONS}

IN the second session of the Convention Parliament, which reassembled on the 25th of October, 1689, the Declaration of Right, which embodied the fundamental principles of the English Constitution and of the ancient franchises of the English nation, was confirmed with some slight but important amendments in a regular act of the Legislature. This Act is known as the Bill of Rights. The Convention Parliament had met on the 22nd of January, 1688, and a week later, the Commons passed their celebrated Resolution, in which, as James II. had abdicated the throne, it was deemed inconsistent with the safety of the kingdom that a Protestant government should be in the hands of a "Popish Prince." After conferences between William and the political leaders, as well as between the two Houses, it was resolved that a Committee of the Commons should consider what steps it might be advisable to take to secure law and liberty against the aggressions of future sovereigns.

The Declaration of Right was accordingly drawn up.

In studying the Bill of Rights it is necessary to understand thoroughly the reaction against Puritanism after the Restoration and the subsequent revival of Protestant feeling produced by James II.'s policy toward the church and the government. The position of William of Orange on the continent, both as military hero and political governor, must also be taken into consideration. All later Bills of Rights take their key-note from this famous document, of which Taswell-Langmead speaks as "the third great charter of English liberty and the coping-stone of the Constitutional Building."

For Outlines and Material see Appendix A.

\section{DOCUMENT}

The Bill of Rights Oct. 25 (x689)

The Statutes of the Realm. VI. 142-145.
An Act for Declaring the Rights and Liberties of tile Subject, and Setrling the SuccesSiON OF THE Crown. 
Whereas the Lords Spiritual and Temporal, and Based upon Commons, assembled at Westminster, lawfully, the Declarafully, and freely representing all the estates of the Right which people of this realm, did upon the 'Thirteenth day accompanied of February, in the year of our Lord One Thousand the offer of Six Hundred Eighty-eight, present unto their Majes- William and ties, then called and known by the names and style Mary. $13,168$. of William and Mary, Prince and Princess of Orange, being present in their proper persons, a certain Declaration in writing, made by the said Lords and Commons, in the words following, viz. :-

"Whereas the late King James II., by the assistance of divers evil counsellors, judges, and ministers employed by him, did endeavour to subvert and extirpate the Protestant religion, and the laws and liberties of this kingdom:-

(1.) By assuming and exercising a power of dis- In early pensing with and suspending of laws, and the execu- times the tion of laws, without consent of Parliament.

(2.) By committing and prosecuting divers worthy prelates, for humbly petitioning to be excused from power had been conconcurring to the said assumed power.

(3.) By issuing and causing to be executed a commission under the Great Seal for erecting a court, called the Court of Commissioners for Eeclesiastical Causes.

(4.) By levying money for and to the use of the Compare the Crown by pretence of prerogative, for other time following and in other manner than the same was granted by with the Parliament.

Declaration

(5.) By raising and keeping a standing army of Independwithin this kinglom in time of peace, without consent of Parliament, and quartering soldiers contrary to law.

(6.) By causiug several good subjeets, being Protestants, to be disarmed, at the same time when Papists were both armed and employed contrary to law. 
(7.) By violating the freedom of election of members to serve in Parliament.

(8.) By prosecutions in the Court of King's Bench for matters and causes cognizable only in Parliament; and by divers other arbitrary and illegal causes.

(9.) And whereas of late years, partial, corrupt, and unqualified persons have been returned, and served on juries in trials, and particularly diverse jurors in trials for high treason, which were not freeholders.

(10.) And excessive bail hath been required of persons committed in criminal cases, to elude the benefit of the laws made for the liberty of the subjects.

(11.) And excessive fines have been imposed; and illegal and cruel punishments inflicted.

(12.) And several grants and promises made of fines and forfeitures, before any conviction or julgment against the persons upon whom the same were to be levied.

All which are utterly and directly contrary to the known laws and statutes, and freedom of this realm.

And whereas the said late King James II. having abdicated the government, and the throne being thereby vacant, his Highness the Prince of Orange (whom it hath pleased Almighty God to make the glorious instrument of delivering this kingilom from Popery and arbitrary power) did (by the advice of the Lords Spiritual and Temporal, and diverse principal persons of the Commons) cause letters to be

Summons to the Convention Parliament. written to the Lords Spiritual and Temporal, being Protestants, and other letters to the several counties, eitics, universities, boroughs, and cinque ports, for the choosing of such persons to represent them, as were of right to be sent to Parliament, to meet and sit at Westminster upon the two-and-twentieth day of January, in this year one thousand six hun- 
dred eighty and eight, in order to sueh an establishment, as that their religion, laws, and liberties might not again be in danger of being subverted; upon which letters elections have been accordingly made.

And thereupon the said Lords Spiritual and Temporal, and Commons, pursuant to their respective letters and elections, being now assembled in a full and free representation of this nation, taking into their most serious consideration the best means for attaining the ends aforesaid, do in the first place (as their ancestors in like case have usually done), for the vindicating and asserting their ancient rights and liberties, declare :-

(1.) That the pretended power of suspending of laws, or the execution of laws, by regal authority, without consent of Parliament, is illegal.

(2.) That the pretended power of dispensing with laws, or the execution of laws by regal authority, as it hath been assumed and exercised of late, is illegal.

(3.) That the commission for erecting the late Court of Commissioners for Ecclesiastical causes, and all other commissions and courts of like nature, are illegal and pernicious.

(4.) That levying money for or to the use of the Crown by pretence of prerogative, without grant of Parliament, for longer time or in other manner than the same is or shall be granted, is illegal.

(5.) 'That it is the right of the subjects to petition the King, and all commitments and prosecutions for such petitioning are illegal.

(6.) That the raising or keeping a standing army within the kingdom in time of peace, unless it be with consent of Parliament, is against law.

(7.) That the subjects which are Protestants From 1695 to may have arms for their defence suitable to their 1728 , effort to conditions, and as allowed by law.

(8.) That election of members of Parliament Great inought to be free. 
crease of bribery, time proceedings in Parliament, ought not to be im-
Geo. III.

This act first peached or questioned in any court or place out enforced in of Parliament.

1407.

See Magna Charta, Art. xxxvi.
This is the first official statement that the
(10.) That excessive bail ought not to be required, nor excessive fines imposed; nor cruel and unusual punishments inflicted.

(11.) That jurors ought to be duly impanelled and returned, and jurors which pass upon men in trials for high treason ought to be freeholders.

(12.) That all grants and promises of fines and forfeitures of particular persons before conviction are illegal and void.

(13.) And that for redress of all grievances, and for the amending, strengthening, and preserving of the laws, Parliament ought to be held frequently.

And they do claim, demand, and insist upon all and singular the premises, as their undoubted rights and liberties; and that no declarations, judgments, doings or proceedings, to the prejudice of the people in any of the said premises, ought in any wise to be drawn hereafter into consequence or example.

To which demand of their rights they are particularly encouraged by the declaration of his Highness the Prince of Orange, as being the only means for obtaining a full redress and remedy therein.

Having therefore an entire confidence that his said Highness the Prince of Orange will perfect the deliverance so far advanced by him, and will still preserve them from the violation of their rights, which they have here asserted, and from all other attempts upon their religion, rights, and liberties :

II. The said Lords Spiritual and Temporal, and Commons, assembled at Westminster, do resolve, that William and Mary, Prince and Princess of Orange, be, and be declared, King and Queen of England, France, and Ireland, and the dominions thereunto belonging, to hold the crown and royal dignity of the said kingdoms and dominions to them 
the said Prince and Princess during their lives, and crown of the life of the survivor of them; and that the sole England can and full exercise of the regal power be only in, by Parliaand exccuted by, the said Prince of Orange, in the ment. names of the said Prince and Princess, during their joint lives ; and after their deceases, the said Crown and royal dignity of the said kingdoms and dominions to be to the heirs of the body of the said Princess; and for default of such issue to the Princess Anne of Denmark, and the heirs of her body; and for default of such issue to the heirs of the body of the said Prince of Orange. And the Lords Spiritual and Temporal, and Commons, do pray the said Prince and Princess to accept the same accordingly.

III. And that the oaths hereafter mentioned be taken by all persons of whom the oaths of allegiance New oath of and supremacy might be required by law, instead of them; and that the said oaths of allegiance and supremacy be abrogated. allegiance, with supremacy oath.

"I, A. B., do sincerely promise and swear, That I will be faithful and bear true allegiance to their Majesties King William and Queen Mary:

"So help me God."

"I, A. B., do swear, That I do from my heart abhor, detest, and abjure as impious and heretical Supremacy. that dammable doctrine and position, that Princes excommunicated or deprived by the Pope, or any authority of the See of Rome, may be deposed or murdered by their subjects, or any other whatsoever. And I do declare, That no foreign prince, person, prelate, state, or potentate hath, or ought to have, any jurisdiction, power, superiority, preeminence, or anthority, ecclesiastical or spiritual, within this realm:

"So help me God!"

IV. Upon which their said Majesties did accept Agreement the Crown and royal dignity of the kingdoms of between Fngland, France, and Ireland, and the dominions Prown and thereunto belonging, according to the resolution 
and desire of the said Lords and Commons contained in the said declaration.

V. And thereupon their Majesties were pleased, that the said Lords Spiritual and Temporal, and Commons, being the two Houses of Parliament, should continue to sit, and with their Majesties' royal concurrence make effectual prorision for the settlement of the religion, laws and liberties of this kingdom, so that the same for the future might not be in danger again of being subverted; to which the said Lords Spiritual and Temporal, and Commons, did agree and proceed to act accordingly.

VI. Now in pursuance of the premises, the said Lords Spiritual and Temporal, and Commons, in

See Declaration of Independence.
Parliament assembled, for the ratifying, confirming, and establishing the said declaration, and the articles, clauses, matters, and things therein contained, by the force of a law made in due form by authority of Parliament, do pray that it may be declared and enacted, That all and singular the rights and liberties asserted and claimed in the said declaration are the true, ancient, and indubitable rights and liberties of the people of this kingdom, and so shall be esteemed, allowed, adjudged, deemed, and taken to be, and that all and every the particulars aforesaid shall be firmly and strictly holden and observed, as they are expressed in the said declaration; and all officers and ministers whatsoever shall serve their Majesties and their successors according to the same in all times to come.

VII. And the said Lords Spiritual and Temporal, and Commons, seriously considering how it hath pleased Almighty God, in his marvellous providence, and mereiful goodness to this nation, to provide and preserve their said Majesties' royal persons most happily to reign over us upon the throne of their ancestors, for which they render unto Him from the bottom of their hearts their humblest 
thanks and praises, do truly, firmly, assuredly, and in the sincerity of their hearts, think, and do hereby recognize, acknowledge, and declare, that King James II. having abdicated the Government, and their Majesties having accepted the Crown and royal dignity aforesaid, their said Majesties did become, were, are, and of right ought to be, by the laws of this realm, our sovereign liege Lord and Lady, King and Queen of England, France, and Ireland, and the dominions thereunto belonging, in and to whose princely persons the royal state, crown, and dignity of the same realms, with all houours, styles, titles, regalities, prerogatives, powers, jurisdictions, and authorities to the same belonging and appertaining, are most fully, rightfully, and entirely invested and incorporated, united, and annexed.

VIII. And for preventing all questions and divisions in this realm, by reason of any pretended Limitations titles to the Crown, and for preserving a certainty in settlement in the succession thereof, in and upon which the unity, peace, tranquillity, and safety of this nation doth, under Grod, wholly cousist and depend, the said Lords Spiritual and Temporal, and Commons, do beseech their Majesties that it may be enacted, established, and declared, that the Crown and regal government of the said kingdoms and dominions, with all and singular the premises thereunto belonging and appertaining, shall be and continue to their said Majesties, and the survivor of them, during their lives, and the life of the survivor of them. And that the entire, perfect, and full exercise of the regal power and government be only in, and executed by, his Majesty, in the names of both their Majesties, during their joint lives; and after their deceases the said Crown and premises shall be and remain to the heirs of the body of her Majesty: and for :lef:ult of such issue, to her Royal Highness the Princess Anne of Denmark, and the heirs of her 
body; and for default of such issue, to the heirs of the body of his said Majesty: And thereunto the said Lords Spiritual and Temporal, and Commons, do, in the name of all the people aforesaid, most humbly and faithfully submit themselves, their heirs and posterities, forever: and do faithfully promise, That they will stand to, maintain, and defend their said Majesties, and also the limitation and

See Act of Settlement.

Exclusion clause. succession of the Crown herein specified and contained, to the utmost of their powers, with their lives and estates, against all persons whatsoever that shall attempt anything to the contrary.

IX. And whereas it hath been found by experience, that it is inconsistent with the safety and welfare of this Protestant kingdom, to be governed by a Popish prince, or by any king or queen marrying a Papist, the said Lords Spiritual and Temporal, and Commons, do further pray that it may be enacted, That all and every person and persons that is, are, or shall be reconciled to, or shall hold communion with, the See or Church of Rome, or shall profess the Popish religion, or shall marry a Papist, shall be excluded, and be for ever incapable to inherit, possess, or enjoy the Crown and Government of this realm, and Ireland, and the dominions thereunto belonging, or any part of the same, or to have, use, or exercise any regal power, anthority, or jurisdiction within the same; and in all and every such case or cases the people of these realms shall be and are hereby absolved of their allegiance; and the said Crown and Government shall from time to time descend to, and be enjoyed by, such person or persons, being Protestants, as should have inherited and enjoyed the same, in case the said person or persons so reconciled, holding communion, or professing, or marrying, as aforesaid, were naturally dead.

$\mathrm{X}$. And that every King and Queen of this realm, who at any time hereafter shall come to and 
succeed in the Imperial Crown of this kingdom, Future Decshall, on the first day of the meeting of the first laration.

Parliament, next after his or her coming to the Crown, sitting in his or her throne in the House of Peers, in the presence of the Lords and Commons therein assembled, or at his or her coronation, before such person or persons who shall administer the coronation oath to him or her, at the time of his or her taking the said oath (which shall first happen), make, subscribe, and audibly repeat the declaration mentioned in the statute made in the thirteenth year of the reign of King Charles II., intituled "An act for the more effectual preserving the King's person and Government, by disabling Papists from sitting in either Honse of Parliament." But if it shall happen, that such King or Queen, upon his or her succession to the Crown of this realm, shall be under the age of twelve years, then every such King or Queen shall make, subscribe, and audibly repeat the said declaration at his or her coronation, or the first day of meeting of the first Parliament as aforesaid, which shall first happen after such King or Queen shall have attained the said age of twelve years.

XI. All which their Majesties are contented and pleased shall be declared, enacted, and established Enacting by authority of this present Parliament, and shall Clause. stand, remain, and be the law of this realm for ever; and the same are by their said Majesties, by and with the advice and consent of the Lords Spiritual and Temporal, and Commons, in Parliament assembled, and by the authority of the same, declared, enacted, or established accordingly.

XII. And be it further declared and enacted by the authority aforesaid, That from and after this Dispensing present session of Parliament, no dispensation by power renon obstante of or to any statute, or any part thereof, shall be allowed, but that the same shall be held void and of no effect, except a dispensation be 
allowed of in such statute, and except in such cases as shall be specially provided for by one or more bill or bills to be passed during this present session of Parliament.

XIII. Provided that no charter, or graut, or pardon granted before the three-and-twentieth day of October, in the year of our Lord One thousand six hundred eighty-nine, shall be any ways impeached or invalidated by this Act, but that the same shall be and remain of the same force and effect in law, and no other, than as if this Act had never been made.

\section{CONTEMPORARY EXPOSITION}

BISHOP BURNET (1724)

There was a bill of great importance sent up by the Commons to the Lords : . . . it was a bill, declaring the rights and liberties of England, and the succession to the Crown, as had been agreed by both houses of parliament, to the king and queen and their issue. . . The lill passed without opposition in the beginning of the next session, which I mention here that I might end this matter all at once.

Gilbert Burnet, History of His Oun Time. 533.

\section{CRITICAL COMMENT}

LUFFMAN (1792)

The Constitution of England, as established under the sacred authority of Magna Charta, had, at the crisis which produced the Bill of Rights, become very much impaired by the many encroachments which some of the succeeding kings from the time of John made upon its equitable form. ... The moment that the Declaration of Right was made on the behalf of the English People and acknowledged by the Prince of Orange and his consort as the supreme law, in future to be observed, at that instant the constitution was renovated, the power of the crown was acknowledged to flow from its only 
natural source, the people, and a reciprocal interest, proceeding from allegiance on one part and protection on the other, formed the guarantee of the monarch's prerogative and the people's freedom.

J. Luffman, Citizen and Goldsmith, a pamphlet.

GUIZOT (1842)

All England, except a very small party, was at this time arrayed against James; and it seems very certain, that, under some form or other, the revolution of 1688 must have been accomplished. But at this crisis causes even superior to the internal state of England conduced to this event. It was European as well as English. It is at this point that the English revolution links itself, by facts, and independently of the influence of its example, to the general course of European civilization.

Guizot, General History of Civilization from the Fall of the Roman Empire to the French Revolution. 285.

\section{MACAULAY (1849)}

This revolution, of all revolutions the least violent, has been of all revolutions the most beneficent. It finally decided the great question whether the popular element which had, ever since the age of Fitzwalter and De Montfort, been found in the English polity, should be destroyed by the monarchical element, or should be suffered to develop itself freely, and to become dominant. The strife between the two principles had been long, fierce, and doubtful. It had lasted through four reigns. It had produced seditions, impeachments, rebellions, battles, sieges, proscriptions, judicial massacres. Sometimes liberty, sometimes royalty, had seemed to be on the point of perishing. During many years one half of the energy of England had been employed in counteracting the other half. The executive power and the legislative power had so effectually impeded each other that the state had been of no account in Europe. The king-atarms, who proclaimed William and Mary before Whitehall Gate, did in truth announce that this great struggle was over; that there was entire union between the throne and the Parliament; that England, long dependent and degraded, was again a power 
of the first rank; that the ancient laws by which the prerogative was bounded would thenceforth be held as sacred as the prerogative itself, and wonld be followed out to all their consequences; that the executive aduinistration would be conducted in conformity with the sense of the representatives of the nation; and that no reform which the two houses should, after mature deliberation, propose, would be obstiuately withstood by the sovereign. The Declaration of Rights, though it made nothing law which had not been law before, contained the germ of the law which gave religious freedom to the Dissenter, of the law which secured the independence of the judges, of the law which limited the duration of Parliaments, of the law which placed the liberty of the press under the protection of juries, of the law which prohibited the slave-trade, of the law which abolished the sacramental test, of the law which relieved the Roman Catholics from eivil disabilities, of the law which reformed the representative system, of every good law which has been passed during a hundred and sixty years, of every good law which may hereafter, in the course of ages, be found necessary to promote the public weal, and to satisfy the demands of public opiuion.

T. B. Macaulay, History of England. III. 518.

\section{J. R. GREEN (1874)}

The Declaration of Rights was turned into the Bill of Rights by the Convention which had now become a Parliament, and the passing of this measure in 1689 restored to the monarchy the character which it had lost under the Tudors and Stuarts. . . . Since their day [William and Mary] no English sovereign has been able to advance any claims to the crown save a claim which has rested on a particular clause in a particular Act of Parliament. . . An English monarch is now as much the creature of an Act of Parliament as the petty tax-gatherer in his realm.

J. R. Grees, Short History of the English People. 688-689.

TASWELL-LANGMEAD (1879)

The Revolution of 1688 marks at once a resting-place and a fresh point of departure in the history of the English Constitution. The Bill of Rights was a summing up, as it were, and 
final establishment of the Legal bases of the Constitution. With Magna Charta and the Petition of Right it forms the Legal Constitutional Code to which no additions of equal importance (except the Constitutional provisions of the Act of Settlement to be presently noticed) have since been made by Legislative enactment. Political progress has indeed, from time to time, left its mark on the statute-book, in laws the importance of which can hardly be exaggerated. But even the greatest of these enactments . . . have been of the nature of amendments to the machinery of the Constitution, supplying defects and correcting abuses, rather than alterations in the great Constitutional principles finally established by the Revolution.

T. P. Tasweld-Langmead, English Constitutional History. 550.

\section{HANNIS TAYLOR (1889)}

Ten days after the accession of William and Mary, the royal assent was given to a bill which declared the convention a parliament, " notwithstanding any fault of writ or writs of summons;" and on the 20th of August, after seven months of active work, it took a recess until the 19 th of October. Then it was that the act was passed which turned the Declaration of Right into a formal Bill of Rights, whereby two somewhat important additions were made to the original instrument.

The Declaration of Right thus put forth was a summing up in a dogmatic form of that code of positive law regulating the prerogatives of the crown, the privileges of parliament, and the liberty of the subject now generally known as "The Law of the Constitution," as distinguished from that body of political maxims, of silent understandings, undefined either by common or statute law, which have been invented since the beginning of the reign of William III.

HANnis TAYLOR, Origin and Growth of the English Constitution. II. 418-415.

\section{J. K. HOSMER (1890)}

The monarchy as limited in the thirteenth century had come down to the seventeenth century. Parliament had behind it a past of four hundred years. The constitution was not 
formulated, but its principles, scattered throughout timehonoured statutes, were engraven on the hearts of Englishmen. No one of its principles was based upon precedents more ancient or more frequent than that Kings reigned by a right in no respect differing from that by which knights-of-the-shire exercised authority in behalf of their constituents. The Bill of Rights simply affirmed this principle. Not a single new right was given to the people; the whole body of English law was unchanged; all was conducted in obedience to the ancient formalities.

J. K. Hosmer, Anglo-Saxon Freedom. 169.

STEVENS (1894)

The Bill of Rights of the time of William and Mary finally declares, "that levying money for or to the use of the crown by pretence of prerogative without grant of Parliament for longer time, or in other manner than the same is or shall be granted, is illegal." It is not too much to say, that the principle lies at the foundation of all others in the English constitution, and is a chief source of modern liberties.

C. E. Stevens, Sources of the Constitution. 114.

RANSOME (1895)

The Declaration of Right, which afterwards was turned into an act of parliament under the title of the Bill of Rights, is one of the most important documents in English history. It brought to a close the great struggle between the king and the parliament, which had lasted nearly one hundred years, by defining the law on a number of disputed points, all of which had, during this period, been matters of protest on the side of the parliament. After taking, one by one, the chief nnconstitutional acts of James II., it proceeded to make the following declarations: ....

The effect of the Revolution was threefold. In the first place, it destroyed the Stuart theory of the divine right of kings, enunciated in its crudest form by Filmer in his de Patriarch $\hat{a}$, by setting up a king and queen who owed their position to the choice of parliament. In the second, it gave an opportunity for reasserting the principles of the English con- 
stitution which it had been the aim of the Stuarts to set aside. In the third, it began what may be called the reign of Parliament. Up to the Revolution there is no doubt that the guiding force in directing the poliey of the nation had been the will of the king. Sinee the Revolution the guiding force has been the will of the parliament.

Cyril Ransome, Advanced Itistory of England. 664,665. 


\section{Chapter X \\ ACT OF SETTLEMENT}

\section{SUGGESTIONS}

THE Act of Settlement itself reads, "An act for the further limitation of the Crown and better securing the Rights and Liberties of the Subject." The Constitutional Provisions are the articles most important; they settled the question of the succession once and for all time. In 1701 the death of Anne's only son, a lad of twelve years, brought matters to a climax. 'Tories and Whigs, alike, deemed it imperative to act inmediately and unanimously. Thus, by pressure of events, the two Houses passed the famous Act of Settlement by which, in case of the death of both Amne and William without heirs, the crown was settled upon Sophia, the granddaughter of James I. The whole question of the Hanoveriau Succession was thus placed outside of the political party factions of that reign, and all succeeding ones.

Although the Bill of Rights was supposed in itself to settle the question of succession, it was deemed wise in the reign of Queen Anne to draw up the Act of Settlement, a statute important, not only on account of the group of constitutional provisions embodied in it, bnt also as the "Title deed" of the reigning dynasty, and a veritable "Original Contract between the Crown and the People." In studying the period to which the document forms the central thought, too much stress cannot be laid upon the responsibility taken by the government for the support of the Established Church, and its doctrines. The History of the Anglican Church does not fall within the field of this volume, but the vitality of State and Church are one.

For Outlines and Material, see Appendix A.

\section{DOCUMENT}

Constitutional Provisions in the Act of Settlement (r700-170r)

Transliter- 1. That whosoever shall hereafter come to the ated from the possession of this Crown shall join in communion Statutes of the with the Church of England as by law established.
Realm. VII. with 747-750. 2. That in case the Crown and Imperial dignity 
of this realm shall hereafter come to any person not being a native of this kingdom of England, this nation be not obliged to engage in any war for the defence of any dominions or territories which do not belong to the Crown of England, without the consent of Parliament.

3. That no person who shall hereafter come to Repealed in the possession of this Crown shall go out of the the first year dominions of England, Scotland, or Ireland, with- reign. out consent of Parliament.

4. That from and after the time that the further limitation by this Act shall take effect, all matters Repealed by and things relating to the well governing of this 4 Anne, c. 8 , kingdom, which are properly cognisable in the Privy Council by the laws and customs of this realm, shall be transacted there, and all resolutions taken thereupon shall be signed by such of the Privy Council as shall advise and consent to the same.

5. That, after the sair limitation shall take effect as aforesaid, no person born out of the kingdoms This article of England, Scotland, or Ireland, or the dominions helped to thereunto belonging (although to be naturalized or parliamenmade a denizen - except such as are born of Eng- tary constilish parents), shall be capable to be of the Privy $\begin{gathered}\text { tution of } \\ \text { Bill }\end{gathered}$ Council, or a member of either House of Parliament, Rights. or to enjoy any office or place of trust, either civil or military, or to have any grant of lands, tenements, or hereditaments, from the Crown, to himself, or to any other or others in trust for him.

6. That no person who has an office or place of Repealed in profit under the King, or receives a pension from the fourth the Crown, shall be capable of serving as a member Anne's reign. of the House of Commons.

7. That, after the said limitation shall take effect This article as aforesaid, judges' commissions be made quamdiu alded the se bene gesserint, and their salaries ascertained pendence of and established; but upon the address of both the justices Houses of Parliament, it may be lawful to remove were they dethem.

pendentupon 
the king's presence, but upon" good behavior."

8. That no pardon under the Great Seal of England be pleadable to an impeachment by the Commons in Parliament.

\section{CONTEMPORARY EXPOSITION}

\section{BISHOP BURNET (1724)}

The matter that occasioned the longest and warmest debates in both houses was an act abjuring the pretended Prince of Wales, and forswearing to the king by the title of rightful and lawful king, and to his heirs, according to the act of settlement. . . . The design of this act was to discover to all, both at home and abroad, how unanimously the nation concurred in abjuring the pretended Prince of Wales.

Gilbert Bunvet, History of His Own Time. 698.

\section{CRITICAL COMMENT}

\section{BLACKSTONE'S COMMENTARIES (1765)}

The absolute rights of every Englishman, which taken in a political and extensive sense, are usually called their liberties, and as they are founded on nature and reason, so they are co-eval with our form of government. . . . The vigour of our free constitution has always delivered the nation from embarrassments . . . and their fundamental articles have been, from time to time, asserted in Parliament as often as they were thought to be in danger. . . . First, by the Great Charter of Liberties, which was obtained sword in hand from King John. ... Afterwards by the Statute called Confirmatio Chartarum whereby the Great Charter is directed to be allowed as the common law.... Then after a long interval, by the Petition of Right, which was a parliamentary declaration of the liberties of the people. . . By the many salutary laws, particularly the Habeas Corpus Act, passed under Charles II. To these succeeded the Bill of Rights . . . which declaration concludes in these remarkable words; "and they do claim, demand, and insist upon all and singular the premises, as their undoubted rights and liberties." ... Lastly, these liberties were again 
asserted at the commencement of the present century in the Act of Settlement, whereby the crown was limited to his present Majesty's illustrious house; and some new provisions were added at the same fortunate era, for better securing our religion, laws, and liberties, which the statute declares to be " the birthright of the people of England," according to the ancient doctrine of the common law.

Sir WM. BLACKSTONe, Commentaries on the Laws of England. I. 127-129.

\section{DICEY (1885)}

The descent of the Crown was varied and finally fixed under the Act of Settlement (12 \& 13 Will. III. c. 2$)$; the Queen occupies the throne under a parliamentary title: her claim to reign depends upon and is the result of a statute. This is a proposition which at the present day no one is inclined either to maintain or to dispute; but a glance at the Statute-book shows that not two hundred years ago Parliament had to insist strenuously upon the principle of its own lawful supremacy.

ALbert V. Dicex, Introduction to the Study of the Law of the Constitution. 41.

RANSOME (1895)

The circumstance that the Act of Settlement was passed by a parliament in which the Tories were predominant, turned out to be of great importance, for it committed the Tories, as a party, to the principle of the Hanoverian succession, and as it was an arrangement heartily approved by the Whigs, the matter was thus placed outside the lines of party politics.

Crril Ransome, Advanced History of England. 699. 


\section{Chapter XI \\ SPIRIT OF COLONIAL RIGHTS (1721-1765)}

\section{SUGGESTIONS}

As we approach the intensive study of the Colonial period, no one English statute or New England charter stands out peculiarly as representative of the spirit of political freedom, which was a product of the system of government in the American Colonies. The Defence of the New England Charters, too long to use in full, touches upon many subjects not purely constitutional.

Jeremiah Dummer was an able exponent of New England's principles. The existing difficulties which had arisen are as well set forth in his "Defence" as in any one document of the period. The contemporary exposition gathered about this document is not in itself so closely critical of the articles of the document as with its spirit. From this time until after the formation of the Articles of Confederation it is the general movement of the times, and not the precise criticism of any one document which dominates the thought of the contemporary writer.

For Outlines and Material, see Appendix A.

\section{DOCUMENT}

Extracts from "A Defence of the New-England Charters" (I72I)

A Defence of the New England Charters, $1721,3-74$.

Puritan Emigration, 1628 . by Jer[emiah] Dummer.

To the Right Honourable, the Lord Carteret, one of His Majesty's Principal Secretaries of State.

Invited and encouraged by these advantages, a considerable number of persons dissenting from the discipline of the established church, though agreeing with it in doctrine, removed into those remote regions, upon no other view than to enjoy the liberty of their consciences withont hazard to themselves, and offence to others. Thus the colonies went on 
increasing and flourishing, in spite of all diffieulties, till the year 1684, when the city of London lost its charter, and most of the other corporations in Eng- Magna land, influenced by fear or flattery, complimented Charta, Art. King Charles with a surrender of theirs. In this general ruin of charters at home, it could not be expected that those in America should escape. It was then that a quo warranto was issued against the governour and company of the Massachusets Bay, and soon after a judgment was given against them in Westminster Hall. At the same time Sir Edmund Andros, then the King's governour of New England, did by order from court repair to Hartford, the The story of capital of Connecticut, with armed attendants, and the "Charterforcibly seized their charter for the King Rhode Oak" based Island, finding there was no remedy to be had, made cident that a vertue of necessity, and peaceably resigned theirs. the charter a vertue of necessity, and peaceably resigned theirs. was carried But as soon as the news arrived of the happy off and conrevolution in England, these two last mentioned cealed when governments reassumed their charters, and put about to be themselves under the old form of administration, in which they have continued ever since. 'The gov- Accomernment of the Massachusets, cautious of offending plished their superiours at lome, and considering there was easily upon a judgment against them in the court of Chancery, Andros in thongh most unfairly and illegaly obtained, did not think it adviseable to make this step; but sent She was too agents to court to supplicate, in a humble manner, strong and a too proud to the restoration of their charter. To what misman- adopt the agement, or other cause it was owing, that they did conciliatory not obtain it, and that this loyal corporation was course of the only one either in Old or New England that R. I. did not recover its lost liberty under our late glorious deliverer King William, 'tis now too late, and therefore to no purpose, to enquire. A new charter was ordered, which the province now has, and is not much more than the shadow of the old one.

[Herewith follow the Propositions set forth in the "Defence," and such charges as were brought against the colonists:- ] 
1st Prop. That the charter governments have a good and undoubted right to their respective charters.

2nd Prop. That these governments have by no misbehaviour forfeited their charters.

The subjects abroad claim the privilege of Magna Charta, which says that no man shall be fined above the nature of his offence, and whatever his miscarriage be, a "salvo contenemento fuo" is to be observed by the judge. If, therefore, they have committed faults, let them be chastized, not destroyed. Let not their corporations be dissolved for any other cause than a failure of their allegiance.

Charge 1. That they have neglected the defence of the inhabitants.

Charge 2. That they have exercised arbitrary power.

Charge 3. That the Acts of Trade are disregarded.

Charge 4. That they have made laws repugnant to the laws of Great Britain.

Charge 5. That the charter colonies will grow great and formidable.

3rd Prop. That it is not the interest of the Crown to resume the charters, if forfeited.

4th Prop. 'Tlat it seems inconsistent with justice to disfranchize the charter colonies by an act of Parliament.

\section{CONTEMPORARY EXPOSITION}

ANONYMOUS, "PLAIN STATE OF THE ARGUMENT" (1724)

... It would be inconsistent to say that a King has any power at all, but what is derived ultimately from the People through the Parliament.

Whatever deeds the King executes as King: whatever government he settles; whatever charters he grants must, upon this account, be subjert to the inspection, the controul, the 
alteration which Parliament from time to time may think fit to make.

The settling a colony, is effected by the King's granting a charter to a number of people, to inhabit and cultivate a part of some new acquired dominions, which hitherto has not had a regular government from Great-Britain. But it would be absurd to the highest degree to suppose a King to be able to establish laws in a colony which a Parliament could not alter. If he could, he might also make the same colony independent; or, in other words, he might alienate, that is, dispose of a part of the British Empire. Thus, if charters granted by the King are not liable to the controul of a Parliament, a King of Great-Britain might make himself absolute over all new-conquered, new-ceded, or new-discovered countries. He might fix what terms he pleased, or put the charters into what hands, and for as long a time as he thought best. It must then I think be allowed as a certain position that whatever charters our colonies had granted to them, they are necessarily subject to the Jurisdiction of Parliament. This is equally true whether the Jurisdiction of Parliament is expressed in the charter or not.

The King it is allowed has altered and withdrawn charters. Of course, what the King by his delegated power can legally do, the Parliament by their supreme jurisdiction may undoubtedly effect.

The King issues proclamations, and grants charters to all new colonies. He determines the mode of government, causes duties to be laid on wares, and taxes to be raised for the support of the government of each Province. But if Parliament chooses to alter the modes both of taxation and government, I cannot see the shadow of a reason against the legality of their doing it. It may be at any distance of time, and as the state of the provinces demands. In the first settling a colony, it is sufficient that the King exerts his delegated power, and allows the provinces to assess themselves in a particular manner. But, when provinces grow large, populous and powerful, the supreme jurisdiction of Parliament should always establish the mode of government which is to be pursued.

A Plain State of the Argument between Great Britain and her Colonies. 4-9. 


\section{ANONYMOUS "PROPOSALS" (1757)}

The first settlements of most of our Colonies in America were made by private Adventurers ; many of the Colonies were afterwards incorporated by Charters or Privileges granted by the Crown, with a Power to make Laws, and to establish Courts of Justice, Forms of Judicature, and the Manner of Proceeding, and in some Respects to establish their own Form of Government, under this Limitation, that the Laws or Statutes passed by them, should not be repugnant, but as near as possible agreeable to the Laws of England.

And whereas in those remote Colonies situate near many barbarous Nations, the Incursions of the Sarages, as well as other Enemies, Pirates, and Robbers, might probably annoy them; the said Corporations were anthorized and inpowered to levy, muster, and train all Sorts of Men, of what Condition soever, and to pursue their Enemies as well by Sea as by Land, even without the Limits of their respective Provinces.

It is also proper to mention, that there are several other Colonies that are more immediately dependant on the Crown, both with Respect to their Laws and Constitutions; yet it has been the Pleasure of the Crown, to allow them a kind of legislative Power, under particular Restraints and Limitations.

Now as all those Colonies may in some Particulars be considered, with respect to each other, as so many independant States, yet they ought to be considered as one with respect to their Mother Country; and therefore a Union of the Colonies, for their general Defence, so framed as to oblige them to act jointly, and for the Good of the Whole, can only be made by the Wisdom of our Legislature; and without such an Union, it is impossible to make the Colonies act with Force and Vigour, or to oppose the united Force of the French, altho' much inferior in Point of Number.

There is another 'Thing highly worthy of Attention, viz. that tho' the Charter Governments are entitled to make Bye Laws for the better ordering their own Domestic Affairs, yet they are not entitled to make Laws which may have a general Effect, either in obstructing the Trade of this Kingdom, or in laying Restraints and Difficulties on the neighbouring Colonies: For as their Power in a Legislative Capacity originally flows from 
the Crown, under certain Limitations and Restrictions, particularly that of not passing any Laws, but such as are consistent with the Constitution and Laws of this Kingdom, the Intention of the Crown must have been, that the Fitness and Expediency of such Laws should be only cognizable and determinable by the Crown, or by the Legislature in this Kingdom, as it is conceived the Colonies cannot be proper Judges in their own Case : Yet to such Excess have some of the Charter Governments proceeded, particularly Rhode Island and Connecticut, that they have enacted Laws, that no Law shall take Effect in their Colonies, unless it be first authenticated or enacted into a Law by them; and thus they have made themselves Judges of the Fitness and Expediency of their own Laws, by not transmitting them to the proper Boards at Home: Their Charters indeed are injudiciously silent on this Head, yet the Thing is in itself not only fit and reasonable, but absolutely necessary.

And therefore if the Affairs of the Colonies are taken into Consideration in Parliament, it is humbly conceived, that it would be bighly fit and proper to regulate this Matter, in order to prevent the many Incroachments, which several of the Colonies have made with respect to Trade, and in the issuing of Paper Bills of Currency, which hath often had a publick and a general Effect, and greatly injured the Trade and Commerce of this Kingdom; and in Case of an Union amongst the Colonies for their mutual Defence, it would make it impossible for them to make good the Supplies necessary to support the Charge of the Troops which may be sent from one Colony to the Support of another, especially as their Bills of Currency differ greatly in Value, and that they have no regular Course of Exchange between one Province and another: besides, in new Countries they cannot have those Resources which may be had in Countries where Trade and the Course of Exchanges are regularly established.

Proposals for Uniting the English Colonies on the Continent of America. 14-17.

GOVERNOR POWNALL (1765)

Every subject, born within the realm, under the freedom of the Gorernment of Great Britain, or by adoption admitted to 
the same, has an essential, indefeasible right to be governed, under such a mode of government as has the unrestrained exercise of all those powers which form the freedom and rights of the constitution; and therefore "the crown cannot establish any colony upon, - or contract it within a narrower scale than the subject is entitled to, by the great charters of England." The government of each colony must have the same powers, and the same extent of powers, that the government of Great Britain has, - and must have while it does not act contraly to the laws of Great Britain, the same freedom and independence of legislature, as the parliament of Great Britain has. 'This right (they say) is founded not only in the general principles of the rights of a British subject, but is actually declared, confirmed, or granted to them in the commissions and charters which gave them the particular frame of their respective constitutions.

Thomas Pownall, The Administration of the Colonies, pamphlet.

\section{ANONYMOUS, "AMERICA'S APPEAL" (1775)}

III. Let us consider the Rights of the AMERICANS subsequent to their Charters and Colony Constitutions.

As there are certain rights of men, which are unalienable even by themselves; and others which they do not mean to alienate, when they enter into civil society. And as power is naturally restless, aspiring and insatiable ; it therefore becomes necessary in all civil communities (either at their first formation or by degrees) that certain great first principles be settled and established, determining and bounding the power and prerogative of the ruler, ascertaining aud securing the rights and liberties of the subjects, as the foundation stamina of the government; which in all civil states is called the constitution, on the certainty and permanency of which, the rights of both the ruler and the subjects depend; nor may they be altered or changed by ruler or people, but by the whole collective body, or a major part at least, nor may they be touched by the legislator; for the moment that alters essentially the constitution, it annihilates its own existence, its constitutional authority. Not only so, but on supposition the legislator might alter it; such a stretch 
of power would be dangerous beyond conception; for could the British parliament alter the original principles of the constitution, the people might be deprived of their liberties and properties, and the parliament become absolute and perpetual; and for redress in such case, should it ever liappen, they must resort to their native rights, and be justified in unaking insurrection. For when the constitution is violated, they have no other remedy; but for all other wrongs and abuses that may possibly happen, the constitution remaining inviolate, the people have a remedy thereby.

... If, therefore, they were to be considered as English subjects, by the constitution of that kingdom, they had right to enjoy all these privileges; if not as English subjects, then they were theirs without being beholden therefor. In either view, therefore, they were entitled to bave and enjoy all the rights, liberties, and privileges, which, by their several constitutions, were granted and confirmed to them, antecedent thereto. And their constitutions are the original compacts, containing the first great principles, or stamina of their governments; combining the members, connecting and subordinating them to the King as their supreme head and liege Lord; also prescribing the forms of their several governments, determining and bounding the power of the crown over them, within proper limits, and ascertaining and securing their rights, jurisdictions and liberties; and are not to be compared to the charters of corporations in England (although they are to be (leemed sacred) which are royal favours granted to particular corporations, beyond what are enjoyed by the subjects in common; if they should be forfeited and taken away the membe[r]s will still retain the great essential rights of British subjects, and these original compacts were made and entered into by the King, not only for himself, but expressly for his heirs and successors on the one part, and the colonies, their successors and assigns on the other; whereby the connection was formed, not only between the parties then in being, but between the crown and the colonies, through all snccessions of each; and those compacts are permanent and perpetual, as unalterable as Magna Charta, or the primary principles of the English constitution: nor can they be vacater or changed by the king, any 
more than by the colonies, nor be forfeited by one more than the other; for they are mutually obligatory on both, and are the ligaments and bonds that connect the colonies with the king of Great-Britain, and the king with them : cut, therefore, and dissolve them, and the colonies will become immediately disunited from the crown, and the crown from them. Should the original parties to these constitutions awake in their tomb, and come forth (on a controversy that would awake the dead, could the dead be waked) and with united voice testify, that this was their original, true intent and meaning, would it not be awfully striking and convincing? But we have greater evidence; we have their original declaration, made in that day, deliberately reduced to writing, and solemnly ratified and confirmed, which is as follows: "We do, for us, our heirs and successors, grant to, \&c. and their successors, by these presents, that these our letters patent, shall be firm, good, and effectual in the law, to all intents, constructions, and purposes whatever, according to our true intent and meaning herein before declared, as shall be construed, reputed, and adjudged most favourable on the behalf, and for the best benefit and behoof of the grantees, \&c., notwithstanding any omissions therein, or any statute, act, ordinance, provision, proclamation, or restriction heretofore made, had, enacted, ordained, or provided, or any other matter, cause, or thing whatsoever, to the contrary thereof, in any wise notwithstanding."

America's Appeal to the Impartial World. 22-23, 24-26.

\section{CRITICAL COMMENT}

\section{WALSH (1819)}

It is a remarkable trait in the history of the New England settlers, that they did not seek, and appear to have been even unwilling to receive assistance from the mother country. . . .

While the people of New England were providing for their own safety, with consummate judgment, and performing prodigies of valour in innnmerable rencounters with the eneny, they had not even the consolation of escaping the reproach of pusillanimity, from the mother country. 'The court of James II. besides withholding assistance, on the pretext that it was not 
implored, taxed them with wanting hearts to make use of their means of defence. A part of the nation concurred in this injustice; which, even at this distance of time, causes the breast to swell with indignation, when the bold expeditions of these colonists, the prodigal cffusion of their blood, and the hardships of their warfare, are passed in review. This emotion is not allayed, as we read, in descending through their history, that on the occasion of the bill, introduced into the British Parliament, in 1715 , for the destruction of all the charter governments, the first of the charges brought against them was, "the having neglected the defence of the inhabitants!" . .

... In fact, in the very height of the calamity - at the moment when New England was putting forth all her strength for the retention of the soil, - the merchants and manufacturers of the mother country were clamorous, and the committee of plantations tasked, for measures of rigour against her, on the ground that her "inhabitants had encouraged foreigners to traffic with them, and supplied the other plantations with those foreign productions which ought only to have been sent to England." ...

... At a very early period, the mother-country cast the reproach which she has constantly repeated, against the colonists, of provoking the Indian wars, and acquiring the dominion of the Indian territory by fraud as well as force. Dummer's Defence of the Charters, written at the commencement of the last century, treats of this " unworthy aspersion," as the honest author styles it, and as he proves it to be by unanswerable suggestions. With respect to New England particularly, what he asserts is susceptible of abundant evidence - that "she sought to gain the natives by strict justice in her dealings with them, as well as by all the endearments of kindness and humanity;" that "she did not commence hostilities, nor even take up arms of defence, until she found by experience that no other means would prevail " - and, " that nothing could oblige the Indians to peace and friendship, after they conceived a jealousy of the growing powers of the English." The congress of the New England leagne was particularly authorized, to prescribe rules for the conduct of the colonists towards the natives; and its legislation on this head, was tempered with as much for- 
bearance and mercy, as a due regard for self-preservation would possibly admit.

Rовевт Walsh, An Appeal from the Judgments of Great Britain respecting the United States of America. 80-85.

MARSHALL (1824)

In Massachusetts, peace abroad was the signal for dissension at home. Independent in her opinions and habits, she had been accustomed to consider herself rather as a sister kingdom, acknowledging one comınon sovereign with England, than as a colony. The election of all the branches of the legislature, a principle common to New England, contributed, especially while the mother country was occupied with her own internal divisions, to nourish these opinious and habits. Although the new charter of Massachusetts modified the independence of that colony, by vesting the appointment of the goveruor in the crown, yet the course of thinking which had prevailed from the settlement of the country, had gained too much strength to be immediately changed; and Massachusetts sought, by private influence over her chief magistrate, to compensate herself for the loss of his appointment. With this view, it had become usual for the general court to testify its satisfaction with his conduct by presents; and this measure was also adopted in other colonies. ...

In the midst of these contests, governor Shute, who had privately solicited and obtained leave to return to England, suddenly embarked on board the Sea Horse man of war, leaving the controversy concerning the extent of the executive power, to devolve on the lieutenant governor.

The house of representatives persisted in asserting its control over objects which had been deemed within the province of the execntive; but its resolutions were generally negatived by the council. This produced some altercation between the two branches of the legislature; but they at length united in the passage of a resolution desiring their agent in England to take the best measures for protecting the interests of the colony, which were believed to be in danger from the representations of governor Shute... 
Meanwhile the complaints of governor Shute against the house of representatives were heard in England. Every question was decided against the house. In most of them, the existing charter was deemed sufficiently explicit; but, on two points, it was thought advisable to have explanatory articles. These were, the right of the governor to negative the appointment of the speaker, and the right of the house on the subject of adjournment. An explanatory charter therefore passed the seals, affirming the power claimed by the governor to negative a speaker, and denying to the house of representatives the right of adjourning itself for a longer time than two days. This charter was submitted to the general court, to be accepted or refused; but it was accompanied with the intimation that, in the event of its being refused, the whole controversy between the governor and house of representatives would be laid before Parliament. The conduct of the representatives had been so generally condemned in England, as to excite fears that an act to vacate the charter, would be the consequence of a parliamentary inquiry. The temper of the house too had undergone a change. The violence and irritation which marked its proceedings in the contest with governor Shute had subsided; and a majority determined to accept the New charter.

John Marsmall, A History of the Colonies Planted by the English on the Continent of North America. 217-222.

THWAITES (1891)

For many years the New England charters were in imminent danger of annulment, the purpose apparently being to place the colonies under a vice-regal government. Those of Connecticut and Rhode Island were the liberal documents granted to them early in their career; electing their own governors, they were practically independent of the mother-country, and the general movement against the charters bad these two especially in view. From 1701 to 1749 , the charters were serionsly menaced at various times; but on each occasion the astute diplomacy of the colonial agents in England succeeded in warding off the threatened attack. Worthy of especial mention in this connection are Sir Henry Ashurst, the representative of Connecticut, and Jeremiah Dummer, his successor. In 1715, at a time 
when it was proposed to annex Rhode Island and Connecticut to the unchartered royal province of New Hampshire, Dummer issued his now famous Defence of the American charters, in which he forcibly argued, (1) That the colonies "have a good and undoubted right to their respective charters," in as much as they had been irrevocably granted by the sovereign "as premiums for services to be performed." (2) That these governments "have by no misbehaviour forfeited their charters," and were in no danger of becoming formidable to the motherland. (3) That to repeal the charters would endanger colonial prosperity, and "whatever injures the trade of the plantations must in proportion affect Great Britain, the source and centre of their commerce." (4) That the charters should be proceeded against in lower courts of justice, not in parliament. Dummer's presentment of the case was regarded by friends of the colonies as unanswerable, and was largely instrumental in causing an ultimate abandonment of the ministerial attack on the New England charters.

R. G. Tuwates, The Colonies. 266-267. 


\section{Chapter XII \\ THE STAMP ACT CONTROVERSY}

\section{SUGGESTIONS}

WIтH the passage of the Stamp Act in March, 1765, the colonists arose in open defiance against royal oppression. The Stamp Act Congress was called together in New York, and on October 7th, 1765, the document known as the Declaration of Rights and Grievances was drawn up and considered by the nembers. It sets forth the grievances of the colonists, it petitions the king for redress, and it finally asserts that "taxation cannot be constitutionally imposed on them but by their respective legislatures." This Declaration is important because it is the first utterance of the body of American citizens as a whole. Heretofore no concerted action had taken place; the colonists were, for the first time, acting in a body.

In studying ihe period to which this document of the Stamp Act Congress belongs, the British established qualities of character - love of individual freedom and great loyalty to the King - stand out emphatically. Eleven years later, with the Declaration of Independence, the loyalty to the Crown is set aside for the sake of independence of action; in 1765, however, the American colonist was a brave British subject rebelling against injustice, but striving to fulfil his ideal of patriotism to country and fidelity to English law.

For Outlines and Material, see Appendix B.

\section{DOCUMENT}

Declaration of Rights and Grievances of the Colonists in America. Oct. $7^{\text {th }}, 1765$.

The members of this congress, sincerely devoted, Journ. First with the warmest sentiments of affection and duty Cong. Amer. to his majesty's person and government, inviolably Stamp Act attached to the present happy establishment of the Congress asprotestant succession, and with minds deeply im- sembled in pressed by a sense of the present and impending New York. misfortunes of the British colonies on this conti- Settlement. 
nent; having considered as maturely as time would permit, the circumstances of said colonies, esteem it our indispensable duty to make the following declarations, of our humble opinions, respecting the most essential rights and liberties of the colonists, and of the grievances under which they labor, by reason of several late acts of parliament.

1st. That his majesty's subjects in these colonies, owe the same allegiance to the crown of Great Britain, that is owing from his subjects born within the realm, and all due subordination to that august body, the parliament of Great Britain.

2d. That his majesty's liege subjects in these colonies are entitled to all the inherent rights and privileges of his natural born subjects within the kingdom of Great Britain,

$3 \mathrm{~d}$. That it is inseparably essential to the freedom See Confir- of a people, and the undoubted rights of Englishmen, matio Charta- that no taxes should be imposed on them, but with rum. their own consent, given personally, or by their representatives.

4th. That the people of these colonies are not, and from their local circumstances, cannot be represented in the house of commons in Great Britain.

5 th. That the only representatives of the people of these colonies, are persons chosen therein, by themselves; and that no taxes ever have been, or can be constitutionally imposed on them, but by their respective legislatures.

6 th. That all supplies to the crown, being free gifts of the people, it is unreasonable and inconsistent with the principles and spirit of the British constitution, for the people of Great Britain to grant to his majesty t'ie property of the colonists.

Jagna

Charta.

Habeas Corpus Act. 7th. That trial by jury is the inherent and invaluable right of every British subject in these colonies.

8th. That the late act of parliament, entitled, an act for granting and applying certain stamp duties, 
and other duties in the British colonies and p'antations in America, \&c., by imposing taxes on the inhabitants of these colonies, and the said act, and several other acts, by extending the jurisdiction of the courts of admiralty beyond its ancient limits, See Declarahave a manifest tendency to subvert the rights and tion of Indeliberties of the colonists.

9 th. That the duties imposed by several late acts of parliament, from the peculiar circumstances of these colonies, will be extremely burthensome and grievous, and from the scarcity of specie, the payment of them absolutely impracticable.

10th. That as the profits of the trade of these colonies ultimately centre in Great Britain, to pay for the manufactures which they are obliged to take from thence, they eventually contribute very largely to all supplies granted there to the crown.

11th. 'That the restrictions imposed by several Sugar Act. late acts of parliament, on the trade of these colonies, will render them unable to purchase the manufactures of Great Britain.

12th. That the increase, prosperity, and happiness of these colonies, depend on the full and free enjoyment of their rights and liberties, and an intercourse, with Great Britain, mutually affectionate and advantageous.

13th. That it is the right of the British subjects in these colonies, to petition the king or either house of parliament.

Lastly, That it is the indispensable duty of these colonies to the best of sovereigns, to the mother uutil 1775 . country, and to themselves, to endeavor, by a loyal and dutiful address to his majesty, and humble application to both houses of parliament, to procure the repeal of the act for granting and applying certain stamp duties, of all clanses of any other acts of parliament, whereby the jurisdiction of the arlmiralty is extended as aforesaid, and of the other late acts for the restriction of the American commerce.

Note the difference in spirit towards George III. in 1765 , and in 1776. 


\section{CONTEMPORARY EXPOSITION}

FRANKLIN (1766)

Q. Do not you think the people of America would submit to pay the stamp-duty if it was moderated?

A. No, never, unless compelled by force of arms.

Q. What was the temper of America towards Great Britain before the year 1763 ?

A. The best in the world. 'They submitted willingly to the government of the Crown, and paid, in all their courts, obedience to the Acts of parliament. Numerous as the people are in the several old provinces, they cost you nothing in forts, citadels, garrisons or armies, to keep them in subjection. They were governed by this country at the expense only of a little pen, ink and paper. They were led by a thread. They had not only a respect, but an affection, for Great Britain, for its laws, its customs, and manner's, and even a fondness for its fashions, that greatly increased the commerce. Natives of Britain were always treated with particular regard; to be an Old England-man was, of itself, a character of some respect, and gave a kind of rank among us.

Q. And what is their temper now?

A. $O$, very much altered!

Q. Did you ever hear the authority of parliament to make laws for America questioned till lately?

A. The authority of parliament was allowed to be valid in all laws except such as should lay internal taxes. It was never disputed in laying duties to regulate commerce.

Q. In what light did the people of America use to consider the parliament of Great Britain?

A. They considered the parliament as the great bulwark and security of their liberties and privileges, and always spoke of it with the utmost respect and veneration.

Arbitrary ministers, they thought, might possibly at times attempt to oppress them; but they relied on it, that parliament on application, would always give redress. . . . 
Q. And have they not still the same respect for parliament?

A. No, it is greatly lessened.

Q. To what causes is that owing?

A. To a concurrence of causes : the restraints lately laid on their trade, by which the bringing of foreign gold and silver into the colonies was prevented; the prohibition of making paper money among themselves; and then demanding a new and heavy tax by stamps; taking away, at the same time, trials by juries, and refusing to receive and hear their humble petitions.

Q. What is your opinion of a future tax imposed on the same principle with that of the stamp-act; how would the Americans receive it?

A. Just as they do this. 'They would not pay it.

Q. Have not you heard of the resolution of this House, and of the House of Lords, asserting the right of parliament relating to America, including a power to tax the people there?

A. Yes, I have heard of such resolutions.

Q. What will be the opinion of the Americans on those resolutions?

A. They will think them unconstitutional and unjust.

Their opinion is, that when aids to the Crown are wanted, they are to be asked of the several assemblies according to the old established usage, who will, as they always have done, grant them freely. . . . The granting aids to the Crown is the only means they have of recommending themselves to their Sovereign, and they think it extremely hard and unjust, that a body of men, in which they have no representatives should make a merit to itself of giving and granting what is not its own, but theirs, and deprive them of a right they esteem of the utmost value and importance, as it is the security of all their other rights.

Pamphlet: Political, Miscellaneous, and Philosophical Pieces. 1766.

JAMES OTIS (1766)

If it was thought hard that charter privileges should be taken away by aet of Parliament, is it not much harder to be in part, or in whole disfranchised of rights, that have been always 
thought inherent to a British subject, mainly, to be free from all taxes, but what he consents to in person, or by his representative? This right, if it could be traced no higher than Magna Charta, is part of the common law, part of a British subject's birthright, and as inherent and perpetual as the duty of allegiance; both which have been brought to these colonies, and have been hitherto held sacred and inviolable, and $I$ hope and trust ever will. It is humbly conceived that the British colonists (except only the conquered, if any) are, by Magna Charta, as well entitled to have a voice in their taxes as the snbjects within the realm. . . The sum of my argument is, that civil government is of God, that the administrators of it were originally the whole people: . . . that this constitution is the most free one, and by far the best, now existing on earth; that by this constitution, every man in the dominion is a free man; that no parts of his Majesty's dominions can be taxed without his consent; that every part has a right to be represented in the supreme or some subordinate legislature: that a refusal of this would seem to be a contradiction in practice to the theory of the constitution: that the colonies are subordinate dominions, and are now in such a state, as to make it best for the good of the whole, that they should not only be continued in the enjoyment of subordinate legislation, but be also represented in some proportion to their numbers and estates in the grand legislation of the nation; that this would firmly unite all parts of the British empire in the greatest peace and prosperity, and render it invulnerable and perpetual.

JAMEs OTIs, The Rights of the British Colonies. 65-67.

SIR WILLIAM KEITH (1767)

Reasons, humbly offered in Support of the above Proposal to extend the Duties on Stampt Paper and Parchment all over the British Plantations. The author of the above proposal disclaims all views of depriving the British subjects in the plantations of any of those rights and privileges which are derived to them as natural-born subjects of Great Britain; but on the other hand, he cannot consider that part of his Majesty's subjects abroar to be invested with any sort of rights or privileges, that are of 
a higher and more independent Nature than what their bretheren of Great-Britain can claim at home. . . He conceives that the subjects there are under no other Supreme Legislature but that of Great Britain; in so much that every subject in America as often as his occasions require, has an indubitable right to make his humble application to a British Parliament where he virtually conceives himself to be truly represented; because the common interest of the British State of Commonwealth most certainly includes the subjects of America, equally with those of every other part of the Dominion, and so we find it to be understood by the Tenor of the famous Act of Navigation, as well as other restrictive acts relating to commerce and the public revenue.

Sir William Keith, Subject of Taxing the British Colonists in America, pamphlet.

\section{DOCTOR TUCKER'S “LETTER" (1774)}

Indeed it has been my constant remark, that when men were at a loss for solid arguments and matters of fact, in their political disputes, they then had recourse to the spirit of the constitution as to their last shift, and the only thing to say. An American, for example, now insists, that according to the spirit of the English Constitutions, he ought not to be taxed without his own consent, given either by himself or by a representative in Parliament chosen by himself. Why ought he not? The constitution says no such thing. But the spirit of it doth; and that is as good, perhaps better. Very well; see then how the same spirit will presently wheel about and assert a doctrine quite repuguant to the claims and positions of you Americans. Magna Charta, for example, is the great foundation of English liberties, and the basis of the English Constitution. But by the spirit of Magna Charta, all taxes laid on by Parliament are constitutional, legal taxes.

Now remember . . . that the late Tax of Duties upon stamps was laid on by Parliament and therefore according to your own way of reasoning must have been a regular constitutional tax. . . So that if you will now plead the spirit of Magna Charta against the jurisdiction of Parliament you will plead Magna Charta against itself.

Dr. Josian Tucker, Letter from a Merchant in London to his Nephew in America. 


\section{EDMUND BURKE (1774)}

I propose, by removing the ground of the difference and by restoring the former unsuspecting confidence of the colonies in the mother country, to give permanent satisfaction to your people, and (far from a scheme of ruling by discord) to reconcile them to each other in the same act, and by the bond of the very same interest which reconciles them to British Government. . . .

If we adopt this mode; if we mean to conciliate and concede; let us see of what nature the concession onght to be : to ascertain the nature of our concession we must look at their complaint. The colonies complain that they have not the characteristic mark and seal of British freedom. They complain, that they are taxed in a parliament in which they are not represented. If you mean to satisfy them at all, you must satisfy them with regard to this complaint. If you mean to please any people, you must give them the boon which they ask; not what you may think better for them, but of a kind totally different. Such an act may be a wise regulation, but it is no concession. . .

My idea, therefore, without considering whether we yield as matter of right, or grant as matter of favour, is, to admit the people of our colonies into an interest in the constitution; and, by recording that admission in the journals of parliament, to give them as strong an assurance as the nature of the thing will admit, that we mean forever to adhere to that solemn declaration of systematic indulgence. . . .

I . . . wish you to recognize, for the theory, the ancient constitutional policy of this kingdom with regard to representation, as that policy has been declared in Acts of Parliament; and, as to practice, to return to that mode which a uniform experience has marked out to you as best; and in which you walked with security, advantage, and honour until the year 1763 .

My resolutions therefore mean to establish the equity and justice of a taxation of America, by grant, and not by imposition; . . . and to acknowledge that experience has shown the benefits of their grants, and the futility of parliamentary taxation as a method of supply.

Eomuxd Bunke, Speech on Conciliation with the Colonies. Burke's Works, II. 21-60. 


\section{WILLIAM PITT (1774)}

This, my Lords, though no new doctrine, has always been my received and unalterable opinion, and I will carry it to my grave, that this country had no right under heaven to tax America. It is contrary to all the priuciples of Justice and civil polity, which neither the exigencies of the State, nor even an acquiescence in the taxes, could justify upon any occasion whatever. Such proceedings will never meet their wished-for success; and instead of adding to their miseries, as the bill now before you most undoubtedly does, adopt some lenient measures which may lure them to their duty; proceed like a kind and affectionate parent over a child whom he tenderly loves, and instead of those harsh and severe proceedings, pass an amuesty on all their youthful errors, clasp them once more in your fond and affectionate arms; and I will venture to aflirm you will find these children worthy of their sire. But should their turbulence exist after your professed terms of forgiveness, which I hope and expect this house will immediately adopt, I will be among the foremost of your Lordships to move for such measures as will effectually prevent a future relapse, and make them feel what it is to provoke a fond and forgiving parent! a parent, my Lords, whose welfare has been my greatest and most pleasing consolation. This declaration may seem unnecessary; but I will venture to declare, the period is not far distant, when she will want the assistance of her most distant friends; but should the all-disposing hand of Providence prevent me from affording her my poor assistance, my prayers shall be ever for lier welfare.- Length of days be in her right hand, and in her left riches and honour: may her ways be the ways of pleasantness, and all her paths be peace! $†$

William Pitt, Earl of Cuatian's Speech in the House of Lords, 27th day of May, 1774. Chatham's Works, XIII. 292.

$\dagger$ The bill for "Quartering Soldiers" was passed, notwithstanding the eloquence of Pitt. 
JOURNALS OF CONGRESS 1775)

Benjamin Franklin, Arthur Lee, agents, dated, London, February 5th, 1775.

We think it proper to inform you, that your cause was well defended by a considerable number of good and wise men in both houses of parliament, though far from being a majority: and that many of the commercial and manufacturing parts of the nation, concerned in the American trade, have presented, or, as we understand, are preparing to present, petitions to parliament, declaring their great concern, for the present unhappy controversies with America, and praying expressly, or in effect, for healing measures, as the proper means of preserving their commerce, now greatly suffering or endangered.

William Bollen, Journals of Congress (May, 1775). I. 75, 76.

\section{CRITICAL COMMENT}

MACAULAY (1844)

Grenville proposed a measure destined to produce a great revolution, the effects of which will long be felt by the whole human race.

We speak of the act for imposing stamp duties on the North American colonies. . . . The Stamp Act will be remembered as long as the globe lasts. ...

In the meantime, every mail from America brought alarming tidings. The crop which Grenville had sown, his successors had now to reap. The colonies were in a state bordering on rebellion. The stamps were burned. The revenue officers were tarred and feathered. All traftic between the discontented provinces and the mother country was interrupted. . . . The Stamp was indefensible, not because it was beyond constitutional competence of Parliament, but because it was unjust and impolitic, sterile of revenue, and fertile of discontents.

T. B. Macaulay, The Earl of Chatham (Ed. Rev., Oct. 1844).

\section{CHAMBERLAIN (1887)}

When the Stamp Act Congress met in New York, October 7 th, 1765 , that city was the beadquarters of the British forces 
in America, under the command of General Gage. LieutenantGovernor Colden, then filling the executive chair, was in favour of the act, and resolved to execute it; but the Sons of Liberty expressed different sentiments. The Congress contained men some of whom became celebrated. Timothy Ruggles was chosen speaker, but Otis was the leading spirit. In full accord with him were the Livingstons of New York, Dickinson of Peunsylvania, McKean and Rodney of Delaware, Tilghman of Maryland, and Rutland and the elder Lynch of South Carolina. New Hampshire, Virginia, North Carolina and Georgia failed to send delegates, but not for lack of interest in the cause. The Congress prepared a Declaration of Rights and Grievances, an address to the King, a memorial to the House of Lords, and a petition to the House of Commons, and adjourned on October 25 th. For a clear, accurate, and calm statement of the position of the colonies these papers were never surpassed; nor, until the appearance of the Declaration of Independence, was any advance made from the ground taken in them.

Melden Chambrran, The Revolution Impending, in Justro Winsor, Nurrative and Critical History of America. VI. 30-31. 


\section{Chapter XIII \\ VIRGINIA BILL OF RIGHTS}

\section{SUGGESTIONS}

THIs declaration of rights was adopted by a convention that met in Williamsburg, May 6,1776, and was inserted unchanged in the Virginia State Constitutions of $1830,1850-51,1864$, and with some modifications in that of 1870. The Bill was drafted by George Mason and was slightly changed in one clause at the instance of James Madison.

This document is chosen as typical of the spirit of defiance shown in the Revolutionary era, and because it stands as an example of State legislation. Every colony became a state by a similar process of alteration in its colonial government. The student of history should comprehend clearly the theory of constitutional state government, which was the child of English common law or citizenship.

In using this work at this point it would be well for the State Constitution of the Commonwealth nearest in interest to the school to be studied.

For Outlines and Material, see Appendix B.

\section{DOCUMENT}

\section{A Declaration of Rights (June I2th, I776)}

Preston's

Documents, 207-209.

Made by the Representatives of the good People of Virginia, assembled in full and free Convention, which rights to pertain to them and their posterity as the basis and foundation of government.

I. That all men are by nature equally free and independent, and have certain inherent rights, of Compare which, when they enter into a state of society, they with Declara- cannot by any compact, deprive or divest their pendence. posterity; namely, the enjoyment of life and liberty with the means of acquiring and possessing prop- 
erty, and pursuing and obtaining happiness and safety.

II. 'That all power is vested in, and consequently Oath of Office: derived from, the people; that magistrates are Const. Art.ii. their trustees and servants, and at all times amenSect. 1 (8). able to them.

III. That government is, or ought to be, insti- See Bill of tuted for the common benefit, protection and se-Rights; Act curity of the people, nation, or community ; of all of Settlethe various modes and forms of government, that ment; also, is best which is capable of produeing the greatest of Independegree of happiness and safety, and is most effectually secured against the danger of maladministration; and that, when a government shall be found inadequate or contrary to these purposes, a majority of the community hath an indubitable, unalienable and indefeasible right to reform, alter or abolish it, in such manner as shall be judged most conducive to the public weal.

IV. That no man, or set of men, are entitled to exclusive or separate emoluments or privileges from the community but in consideration of public services, which not being descendible, neither ought the offices of magistrate, legislator, or judge to be hereditary.

V. That the legislative, executive and judicial powers should be separate and distinct; and that the members thereof may be restrained from op- The separapression, by feeling and participating the burthens three deof the people, they should, at fixed periods, be partments. reduced to a private station, return into that body i., ii., iii. from which they were originally taken, and the vacancies be supplied by frequent, certain and regular elections, in which all, or any part of the former members to be again eligible or ineligible, as the laws shall direct.

VI. That all elections ought to be free, and that all men having sufficient evidence of permanent common interest with, and attachment to the com- 
munity have the right of suffiage, and cannot be taxed, or deprived of their property for public uses, Confirmatio without their own consent, or that of their repreChartarum. sentatives so elected, nor bound by any law to
VI. which they have not in like manuer assented, for the public good.

VII. 'That all power of suspending laws, or the Bill of Rights, execution of laws, by any authority, without consent of the representatives of the people, is injurious to their rights, and ought not to be exercised.

VIII. That in all capital or criminal prosecutions, Magna a man hath a right to demand the cause and nature Charta, 39- of his accusation, to be confronted with the accusers and witnesses, to call for evidence in his Habeas Cor- favour, and to a speedy trial by an impartial jury pus Act. 'Trial by Jury. of twelve men of his vicinage, without whose unanimous consent he cannot be found guilty; nor can he be compelled to give evidence against himself; that no man be deprived of his liberty, except by the law of the land or the judgment of his peers.

Bill of Rights,

IX. That excessive bail ought not to be required, Art. 10. nor excessive fines imposed, nor cruel and unusual punishments inflicted.

$\mathrm{X}$. That general warrants, whereby an officer or Writs of As- messenger may be commanded to search suspected sistance un- places without evidence of a fact committed, or to warranted. seize any person or persons not named, or whose offence is not particularly described and supported by evidence, are grievous and oppressive, and ought not to be granted.

XI. That in controversies respecting property, See Chapter and in suits between man and man, the ancient V. trial by jury of twelve men is preferable to any other, and ought to be held sacred.

XII. That the freedom of the press is one of the great bulwarks of liberty, and can never be restrained but by despotic governments.

Const.Art.i., XIII. That a well regulated militia, composed Sect. $s$ (16). of the body of the people, trained to arms, is the 
proper, natural, and safe defence of a free State; that standing armies in time of peace should be avoided as dangerous to liberty: and that in all cases the military should be under strict subordination to, and governed by, the civil power.

XIV. That the people have a right to uniform government; and therefore, that no government separate from or independent of the government of Virginia, ought to be erected or established within the limits thereof.

$X V$. That no free government, or the blessing of liberty, can be preserved to any people, but by a firm adherence to justice, moderation, temperance, frugality and virtue, and by a frequent recurrence to fundamental principles.

XVI. That religion, or the duty which we owe to our Creator, and the manner of discharging it, can be directed only by reason and conviction, not by force or violence; and therefore all men are equally entitled to the free exereise of religion, Freedom of according to the dictates of eonseience; and that religious it is the duty of all to practise Christian forbearance, love and charity towards each other.

\section{CONTEMPORARY EXPOSITION}

WASHINGTON (1776)

To Join Augustine Washington,

Philadelphia, 31 May, 1776.

Dear Brotrer, . . . I am very glad to find that the Virginia Convention have passed so noble a vote, and with so much unanimity. Things have come to that pass now, as to convince us, that we have nothing more to expect from the justice of Great Britain. . . . To form a new government requires infinite care and unbounded attention: for if the foundation is badly laid, the superstructure must be bad. Every man should consider, that he is lending his aid to frame a constitution which is to render millions happy or miserable, and that a matter of such moment eannot be the work of a day.

George Wasinington, Works. IV. 105-107. 


\section{JOHN ADAMS (1776)}

As I supposed no man would think of consolidating this vast continent under one national government, we should probably, after the example of the Greeks, the Dutch, and the Swiss, form a confederacy of States, each of which must have a separate government. That the case of Massachusetts was the most urgent, but that it could not be long before every other Colony must follow her example. That with a view to this subject, I had looked into the ancient and modern confederacies for examples, but they all appeared to me to have been huddled up in a hurry, by a few chiefs. But we had a people of more intelligence, curiosity, and enterprise, who must be all consulted, and we must realize the theories of the wisest writers, and invite the people to erect the whole building with their own hands, upon the broadest foundation. That this could be done only by conventions of representatives chosen by the people in the several colonies, in the most exact proportions. That it was my opinion that Congress ought now to recommend to the people of every Colony to call such conventions immediately, and set up governments of their own, under their own authority ; for the people were the source of all authority and original of all power. These were new, strange, and terrible doctrines to the greatest part of the members, but not a very small number heard them with apparent pleasure, and none more than Mr. John Rutledge, of South Carolina, and Mr. John Sullivan, of New Hampshire.

Congress, however, ordered the letter to lie on the table for further consideration.

On Saturday, June 3d, the letter from the convention of the Massachusetts Bay, dated the 16th of May, being again read, the subject was again discussed, and then,

"Resolved, That a committee of five persons be chosen, to consider the same, and report what in their opinion is the proper advice to be given to that Convention."

The following persons were chosen by ballot, to compose that committee, namely, Mr. J. Rutledge, Mr. Johnson, Mr. Jay, Mr. Wilson, and Mr. Lee. These gentlemen had several conferences with the delegates from our State, in the course of 
which, I suppose, the hint was suggested, that they adopted in their report.

Mr. Rutledge asked me my opinion of a proper form of government for a state. I answered him that any form that our people would consent to institute, would be better than none, even if they placed all power in a house of representatives, and they should appoint governors and judges; but I hoped they would be wiser, and preserve the English Constitution in its spirit and substance, as far as the circumstances of this country required or would admit. That no hereditary powers ever had existed in America, nor would they, or ought they to be introduced or proposed; but that I hoped the three branches of a legislature would be preserved, an executive, independent of the senate or council, and the house, and above all things, the independence of the judges. . . .

On Wednesday, October 18th, the delegates from New Hampshire laid before the Congress a part of the instructions delivered to them by their Colony, in these words : -

"We would have you immediately use your utmost endeavours to obtain the advice and direction of the Congress, with respect to a method for our administering justice, and regulating our civil police. We press you not to delay this matter, as its being done speedily will probably prevent the greatest confusion among us.." . . .

Although the opposition was still inveterate, many members of Congress began to hear me with more patience, and some began to ask me civil questions. "How can the people institute governments?" My answer was, "By conventions of representatives, freely, fairly, and proportionably chosen." "When the convention has fabricated a government, or a constitution rather, how do we know the people will submit to it?" "If there is any doubt of that, the convention may send out their project of a constitution, to the pcople in their several towns, counties, or districts, and the people may make the acceptance of it their own act." "But the people know nothing about constitutions." "I believe you are much mistaken in that supposition; if you are not, they will not oppose a plan prepared by their own chosen friends; but I believe that in every considerable portion of the people, there will be found 
some men, who will understand the subject as well as their representatives, and these will assist in enlightening the rest." "But what plan of a government would you advise?" "A plan as nearly resembling the government under which we were born, and have lived, as the circumstances of the country will admit. Kings we never had among us. Nobles we never had. Nothing hereditary ever existed in the country; nor will the country require or admit of any such thing. But governors and councils we have always had, as well as representatives. A legislature in three branches ought to be preserved, and independent judges." "Where and how will you get your governors and councils?" "By elections." "How, - who shall elect?" "The representatives of the people in a convention will be the best qualified to contrive a mode."

After all these discussions and interrogatories, Congress was not prepared nor disposed to do anything as yet. They must consider farther.

"Resolved, That the consideration of this matter be referred to Monday next."

Monday arrived, and Tuesday and Wednesday passed over, and Congress not yet willing to do anything.

... Yet they could not be brought to agree upon a report and to bring it forward in Congress, till Friday, November 3rd, when Congress, taking into consideration the report of the committee on the New Hampshire instructions, after another long deliberation and debate, -

"Resolved, That it be recommended to the Provincial Convention of New Hampshire, to call a full and free representation of the people, and that the representatives, if they think it necessary, establish such a form of government, as in their judgment will best produce the happiness of the people, and most effectually secure peace and good order in the Province, during the continuance of the present dispute between Great Britain and the Colonies."

By this time I mortally hater the words, "Provinces," "Colonies," and "Mother Country," and strove to get them out of the report. The last was incleed left ont, but the other two were retained even by this committee, who were all as high 
Americans as any in the house, unless Mr. Gadsden should be excepted. Nevertheless, I thought this resolution a triumph, and a most important point gained.

Mr. John Rutledge was now completely with us in our desire of revolutionizing all the governments, and he brought forward immediately some representations from his own State, when

"Congress, then taking into consideration the State of South Carolina, and sundry papers relative thereto being read and considered,

" Resolved, That a committee of five be appointed to take the same into consideration, and report what in their opinion is necessary to be done. The members chosen, Mr. Harrison, Mr. Bullock, Mr. Hooper, Mr. Chase, and Mr. S. Adams."

On November 4 th,

"The committee appointed to take into consideration the State of South Carolina, brought in their report, which being read," a number of resolutions passed, the last of which will be found in page 235 of the Journals, at the bottom.

"Resolved, That if the Convention of South Carolina shall find it necessary to establish a form of government in that Colony, it be recommended to that Convention to call a full and free representation of the people, and that the said representatives, if they think it necessary, shall establish such a form of governinent as in their judgment will produce the happiness of the people, and most effectually secure peace and good order in the Colony, during the continuance of the present dispute between Great Britain and the Colonies.

JoHn ADAMs, Works. III. 17-22.

\section{CRITICAL COMMENT}

\section{HITCHCOCK (1887)}

But these constitutional enactments are also social and political phenomena. We may study them in order to learn, not only what they prescribe, but, so to speak, what they reveal. As such phenomena they have, - not only for the student of historieal jurisprudence but for every thoughtful man, concerned for the future of his country, - a significance quite distinct from that which they have either for the officer who 
must execute, or for the citizen who must obey them. . . . They signify and express, not the "civium ardor mava jubentium," but the conclusions of a free people as to what changes in their organic law will best promote the common welfare.

Henry Hitchoock, American State Constitutions. 8, 9.

\section{J. A. JAMESON (1887)}

The mode adopted by Virginia was similar to that followed in those colonies (N. H. and S. C.). The Provincial Convention elected in April, 1776, to continue in office one year, met at Williamsburg on the 6th of May thereafter, and on the 29th of June following framed and established the first constitution of Virginia. This Convention was elected as a revolutionary assembly, to carry on, as Mr. Jeffer'son expresses it, "the ordinary business of the government," in default of the House of Burgesses, and to "call forth the powers of the State for the maintenance of the opposition to Great Britain." It was not pretended, if the same authority is to be credited, that, in assuming to frame a constitution, the Convention had any warrant or authority whatever, except such as enured to it by virtue of its revolutionary character. In so doing, then, it is regarded, not as a constitutional, but as a Revolntionary Convention. It was not empowered to discharge the special and high function of enacting a fundamental code, by any law or by the express desire of the people, but acted on its own authority: and it did not deign to take upon its work the sense of the people whom it pretended to represent.

Jonn A. Jameson, Treatise on Constitutional Conventions, 125, 126.

\section{GEO. T. CURTIS (1889)}

It is a singular circumstance that, while the Revolutionary government was left to conduct the great affairs of the continent through the mere instrumentality of a congress of delegates, and was thus failing for the want of departments and powers, the states were engaged in applying those great principles in the organization and construction of popular governments, under which they may be formed with rapidity and ease, and which are capable of the most varied adaptation to the circumstances and wants of a free people. 
. . . Fortunately, as we have seen, the previous constitutions of all the colonies had accustomed the people, to a great extent, to the business of government; and when the recommendation of the Continental Congress to the sereral colonies to adopt such governments as would best conduce to their happiness and safety was made immediately after the first effusion of blood, it was addressed to civil societies, in which the people had, in different modes, been long accustomed to witness and to exercise the functions of legislation, and in all of which there were established forms of law, of judicature, and of executive power.

The new political situation in which they now found themselves required, in many of the colonies, but little departure from these ancient institutions. The chief innoration necessary was to bring into practical working the authority of the people in place of that of the crown of England, as the source of all political power. The changes requisite to effect this were of course to be made at once; the materials for these changes existed everywhere, in the representative institutions which had long been a part of the system of every colony since the first settlement of the country. . . . The foundations . . . for popular governments existed in all the colonies, and furnished the means for substituting the new source of political power, the will of the people, in the place of that of an external sovereign.

But there were other materials, also, for the formation of regular and balanced governments, with nearer approaches to perfection and with far greater completeness than a mere democracy can afford to any people, however familiar they may be with the exercise and the practice of government. The people of these colonies had been so trained as to be able to apply those principles in the construction and operation of government which enable it to work freely, successfully, and wisely, while resting on a popular basis. They were able to see that the whole of what is meant and understood by government is comprehended in the existence and due operation of legislative, executive, and judicial powers. They had lived under political arrangements, in which these powers had been distributed so as to keep them for the most part distinct 'from 
each other, and so as to mark the proper limitations of each. If, in some instances, the same individuals had exercised more than one of these powers, the distinctions between the departments, and the principles which ought to regulate such distinctions, had become known. The people of the colonies, in general, therefore, saw that nothing was so important, in constructing a government with popular institutions, as to balance each of these departments against the others, so as to leave to neitber of them uncontrolled and irresponsible power.

... Three of the colonies, namely, New Hampshire, South Carolina, and Virginia, proceeded to form constitutions of government before the Declaration of Independence was adopted, under a special recommendation given to each of them by Congress, in the latter part of the year 1775 , addressed to the provincial convention, advising them "to call a full and free representation of the people, to establish such a form of govermment as in their judgment will best promote the happiness of the people, and most effectually secure good order in the province during the continuance of the present dispute between Great Britain and the colonies." ... On the 15th of May, 1776, the Provincial Convention of Virginia proceeded to prepare a declaration of rights and a constitution. The latter declared that the legislative, executive, and judiciary departments ought to be distinct and separate, and divided the legislative department into two branches, the house of delegates and the senate, to be called "the General Assembly of Virginia." The members of the house of delegates were chosen from each county, and one from the city of Williamsburg, and one from the borough of Norfolk. The senate consisted of twenty-four members, chosen from as many districts. A governor and council of state were chosen annually by joint ballot of both houses. The legislature appointed the judges, who were commissioned by the governor, and beld their oflices during good behaviour.

G.T. Curtis, Constitutional History. ${ }^{1} \quad$ I. 80-84. BORGEAUD (1892)

European critics of American democracy almost always make the mistake of looking only at the Federal Constitution of the 1 Copyright, 1859, by George Ticknor Curtis. 
United States and of leaving unexamined the institutions of the sereral States. It may be said, in their defence, that the Americans themselves are the cause of this, since, for a century, they have devoted all their zeal to the history and criticism of Federal public law and are only now beginning the systematic study of their local constitutions. But the mistake, though explicable and pardonable, is none the less grave. Recently two masters of political science, M. E. Boutmy, in France, and Mr. James Bryce, in England, have called attention to its unhappy consequences. They have easily shown that the institutions of the States are the edifice itself of which the Federal constitution is but the completion, that they are the real foundation of the national institutions, and that American democracy cannot be understood or judged apart from the environment in which its development has taken place.

Charles Borgenud, Adoption and Amendment of Constitutions in Europe and America, translated by C. D. Hazen. 137.

\section{BRYCE (1896)}

When, in 1776, the thirteen colonies threw off their allegiance to King George III., and declared themselves independent States, the colonial charter naturally became the State eonstitution. In most cases it was remodelled, with large alterations, by the revolting colony. But in three states it was maintained unchanged, except, of course, so far as Crown authority was concerned, viz., in Massachusetts till 1780, in Connecticut till 1818 , and in Rhode Island till 1842. The other States admitted to the Union in addition to the original thirteen, have entered it as organized self-governing communities, with their constitutions already made by their respective peoples. Each Aet of Congress which admits a new State admits it as a subsisting commonwealth, sometimes empowering its people to meet and enact a constitution for themselves (subject to conditions mentioned in the A(t), sometimes accepting and confirming a constitution so already made by the people. Congress may impose conditions which the State constitution must fulfil; and in admitting the six newest States has affected to retain the power of maintaining these conditions in force. But the authority of the State constitutions cloes not flow from 
Congress, but from acceptance by the citizens of the States for which they are made. Of these instruments, therefore, no less than of the constitutions of the thirteen original States, we may say that although subsequent in date to the Federal Constitution, they are, so far as each State is concerned, de jure prior to it. Their authority over their own citizens is nowise derived from it. Nor is this a mere piece of technical law. The antiquity of the older States as separate commonwealths, running back into the heroic ages of the first colonization of America and the days of the Revolutionary War, is a potent source of the local patriotism of their inhabitants, and gives these States a sense of historic growth and indwelling corporate life which they could not have possessed had they been the mere creatures of the Federal Government.

Jayes Bryce, The American Commonwealth. ${ }^{1} 300,301$.

SCHOULER (1897)

Expressed in concise and admirable language, the Virginia Bill of Rights (whose sixteen sections we have thus condensed) was broad and universal in sentiment. breathing the spirit of human brotherhood, without a hint of race or class subjection. The declaration served well for example to the other twelve states; and, so proud of this instrument have Virginians remained that they affixed it unchanged to their new constitution of 1830 , and, amending it but slightly fol the constitution of 1850 , incorporated it once more intact in the new framework of 1864 .

James Schodler, Constitutional Studies. III. 33, 34.

FISHER (1897)

Virginia's constitution was finished June 29. 1776, - a few months after South Carolina's. It was made by a convention of forty-five members of the house of burgesses, and has prefixed to it a bill of rights, adopted June 12, 1776, the first part of which has the language of the opening paragraph of the Declaration of Independence. The rest of the bill of rights is remarkable as being very full and complete and containing more provisions than had ever appeared before in the colonies. Besides the ordinary bill-of-rights provisions, the bill contains

1 Copyright, 1896, by the Macmillan Co. 
some political maxims, and among these is the first statement in our constitutions of the principle that the legislative, executive, and judicial departments of government should be separate, and that the same persons should never exercise the powers of any two of them.

S. G. Fisuer, The Evolution of the Constitution of the United States.

75.

\section{THORPE (1898)}

Before the close of the seventeenth century America was at the threshold of a new civil experience, the distinguishing feature of which was the formulation of the "ancient and undoubted rights of the people of the colonies." A like process was going on in England. The famous Bill of Rights of 1688 is contemporaneous with like measures in the colonies. Americans are more familiar with the political speculations that dominated the country in 1776 than with those equal in influence, that dominated it nearly a century earlier. One clause of the English bill of 1688 survives in its original form in the Constitution of the United States, and in many State constitutions; but it was not accompanied in the seventeenth century by those provisions with which it is now associated. . . .

When the transition from colonies to commonwealths came, it seems, at first glance, almost instantaneons. The State constitutions of 1776 seem struck off at a single stroke in a sense that is not true of the national Constitution. A little reflection, however, will demonstrate that the constitutions, state and national, which distinguish America during the last quarter of the eighteenth century are in no sense political miracles or the product of chance or sudden ideas. These instruments must be taken, in the aggregate, as the written form of a political organism long growing and essentially homogeneous. 'They give the political fabric a common pattern. 'They register the civil experience, not of the colonists only, but of the people of other and earlier times. They may be called chapters in the Bible of politics contributed by democracy in America. Therefore, they must be considered together as a political unit, whose details are local applications of a few cominon principles contained in the bill of rights

The typical declaration is that of Virginia of $17 \% 6$, which, by 
repeated adoption, has long since become common civil property. It consists of sixteen articles, all of whicb rest for authority on the doctrine of natural rights proclaimed in the opening clause. Men cannot be deprived of their rights, nor can they deprive their posterity of them; all power is vested in the people, and is derived from them. Consequently, their representatives are their trustees and servants, and at all times amenable to them. As government is instituted for the common benefit, it must be organized in the form that is best "capable of producing the greatest degree of happiness and safety, and is most effectually secured against the dangers of maladministration." ... The next State to act was Virginia, which, in April, 1776, elected forty-five delegates to a provincial convention. They met at Williamsburg on the 6th of the following May, and on the 29th of June promulgated the first constitution of the commonwealth. This convention, like that of South Carolina of 1778, was a Revolutionary gathering, chosen to supplant the ancient House of Burgesses, and to establish a government that would organize all the forces of the state in opposition to Great Britain. It was not specifically empowered to make a constitution. The frame of government it adopter was destined, however, to continue in force until 1830. This constitution is famed for its bill of rights, drawn up by George Mason.

F. N. Thonpe, Constitutional History of the American People. ${ }^{1}$ 34, 35, 37-49.

CHANNING (1898)

The State Constitutions, 1775, 1776. - Another important step in bringing about the change in sentiment noted in the preceding section, was the necessity for making new provisions for government in the several colonies. In some eases, as in Virginia and New Hampshire, the departure of the royal governors left the people without any government; in other eases, as in Massachusetts, resistance to the royal authorities made new arrangements necessary. In the last-named colony, a revolutionary body termed the Provincial Congress had assumed charge of the government of the province. The people, however, were restless, and those in power turned to the Continental Congress for advice. On June 9, 1775, that body

\footnotetext{
1 Copyright, 1898, by Iiarper \& Brothers.
} 
voted, that as no obedience was clue to the act of Parliament altering the charter of the colony of Massachusetts, nor to a governor who would not obey the direction thereof, he should be considered as absent and the colony were advised to proceed under the charter without a governor "until a governor of his Majesty's appointment will consent to govern the colony according to the charter." . . . Among the first colonies to act under this suggestion was Virginia, which was at the moment governed by a convention elected by the people. It adopted (June, 1776) a constitution which consisted of three parts: a Bill of Rights by George Mason, a Declaration of Independence by 'Thomas Jefferson, and a Frame of Government. The first of these contains an admirable exposition of the American theory of government, equalled in that respect only by the Declaration of Independence of July, 1776, and by the Bill of Rights drawn by John Adams and prefixed to the Massachusetts constitution of 1780 . The clause in the Virginia Bill of Rights declaring for freedom of religion was the earliest enunciation on that subject during the Revolutionary era; it was probably the work of Madison and Patrick Henry. None of these early constitutions was submitted to the people for ratification, with the exception of that of Massachusetts (1780), which was also drafted by a body especially chosen by the people for that purpose.

Eowann Chaxing, Students' History of the United States. 198, 199, 200. 


\section{Chapter XIV}

\section{DECLARATION OF INDEPENDENCE}

\section{SUGGESTIONS}

The Second Continental Congress met in Philadelphia, in the State House (Independence Hall), May 10, 1775. The King's Proclamation declaring the Colonies in rebellion, and calling for volunteers to force them to submit to taxation without representation, and other unjust measures, finally convinced the delegates to Congress of the impossibility of our continuing our allegiance to the English Crown. This document was authorized by the staunch patriots who met together in Philadelphia, in June of 1776, to consider the resolution of the 7th, when the Second Continental Congress resolved "That these United Colonies are, and of right ought to be, free and independent states." John Adams of Massachusetts seconded the motion. Later, a committee of five - Thomas Jefferson of Virginia, John Adams of Massachusetts, Benjamin Franklin of Pennsylvania, Roger Sherman of Connecticut, and Robert R. Livingston of New York - was appointed to draft the Declaration of Independence. Jefferson drew up the paper, though a few alterations were made in it by the Committee and by Congress. It was adopted on July 2, and formally on the evening of July 4, 1776, and signed by John Hancock, President of Congress, and Charles Thomson, Secretary. On August 2, 1776, it was signed by the members, representing the thirteen states.

The text and comments upon the famous Declaration of Independence are but a beginning for the intensive work that may be done upon the document. Each article may be illustrated by referring to the earlier pieces ; and it will be well for each student who is making a thorough study of the subject to look for fresh examples which will strengthen the letter of this declaration. Here again, as in the period of the Stuarts, we find a group of men standing behind the event and its issue, who in themselves were not only exponents of their era, but who helped to shape it. The principles laid down by these patriots formed a basis for civil and federal ideas which influenced the constitutional development of succeeding generations.

For Outlines and Material, see Appendix A. 


\section{DOCUMENT}

The Declaration of Independence

IN CONGRESS, JuLY 4, 1776.

The unamimous 国eclaration of the thirteen unitro States of America.

Facsimile of the original document in

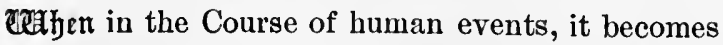
necessary for one people to dissolve the political the Department of bands which have connected them with another, and ington. to assume among the powers of the earth, the separate and equal station to which the Laws of Nature and of Nature's God entitle them, a decent respect to the opinions of mankind requires that they should declare the causes which impel them to the separation. We hold these truths to be I. Statement self-evident, that all men are created equal, that of "selfthey are endowed by their Creator with certain evident, unalienable Rights, that among these are Life, many of Liberty and the pursuit of Happiness, - That to bedded in secure these rights, Governments are instituted English and aning then anong Men, deriving their just powers from the writings of consent of the governed, - That whenever any the time. Form of Government becomes destructive of these See Virginia Forn of Gover of ends, it is the Right of the People to alter or to Rights, 1776. abolish it, and to institute new Government, laying its foundation on such principles and organizing its powers in such form, as to them shall seem most likely to effect their Safety and Happiness. - Prudence. indeed, will dictate that Governments long established should not be changer for light and transient causes; and accordingly all experience hath shewn, that mankind are more disposed to suffer, while evils are sufferable, than to right themselves by abolishing the forms to which they are accustomed. But when a long train of abuses and usurpations, pursuing invariably the same Object evinces a design to reduce them under absolute 
List of Grievances.

Despotism, it is their right, it is their duty, to throw off such Goverument, and to provide new Guards for their future security. — Such has been the patient sufferance of these Colonies; and such is now the necessity which constrains them to alter their former Systems of Government. The history of the present King of Great Britain is a history of repeated injuries and usurpations, all having in direct object the establishment of an absolute Tyranny over these States. To prove this, let Facts be submitted to a candid world. - He has refused his Assent to Laws, the most wholesome and necessary for the public good. - He has forbidden his Governors to pass Laws of immediate and pressing importance, unless suspended in their operation till his Assent should be obtained; and when so suspended, he has utterly neglected to attend to them. He has refused to pass other Laws for the accommodation of large districts of people, unless those people would relinquish the right of Representation in the Legislature, a right inestimable to them

See Magna Charta, art. xvii.

Assemblies in Virginia and elsewhere.
England commanded Colonial Governors to grant no more land, and to allow and formidable to tyrants only. He has called together legislative bodies at places unusual, uncomfortable, and distant from the depository of their public Records, for the sole purpose of fatiguing them into compliance with his measnres. - He has dissolved Representative Houses repeatedly, for opposing with manly firmness his invasions on the rights of the people. — He has refused for a long time, after such dissolutions, to cause others to be elected; whereby the Legislative powers, incapable of Annihilation, have returned to the People at large for their exercise; the State remaining in the mean time exposed to all the dangers of invasion from without, and convulsions within. - He has endeavoured to prevent the population of these States ; for that purpose obstructing the Laws for Naturalization of Foreigners; refusing to pass others to encourage their migration hither, and raising the 
conditions of new Appropriations of Lands. - no settleHe has obstructed the Administration of Justice, by ments west refusing his Assent to Laws for establishing Judi- "sources of ciary powers. - He has made Judges dependent Atlantic on his Will alone, for the tenure of their oflices, and Board, the amount and payment of their salaries. - $\mathrm{He}$ has erected a multitude of New Offices, and sent hither swarms of Officers to harass our people, and eat out their substance. - He has kept among us, in times of peace, Standing Armies without the Consent of our legislatures. — He has affected to render the Military independent of and superior to the Civil power. He has combined with others Parliament. to subject us to a jurisdiction foreign to our constitution, and unacknowledged by our laws; giving British his Assent to their Acts of pretended Legislation: constitution. - For quartering large bodies of armed troops among us: — For protecting them, by a moek Trial, from punishment for any Murders which they should commit on the Inhabitants of these States: — For cutting off our Trade with all parts of the Port Bill. world: - For imposing Taxes on us without our Stamp Act, Consent: — For depriving us in many cases, of Tea Tax, etc. the benefits of Trial by Jury : —— For transporting Jury us beyond Seas to be tried for pretended offences: Vice-Admi_ For abolishing the free System of English Laws ralty court. in a neighbouring Province, establishing therein an See TransArbitrary government, and enlarging its Boundaries Bill. so as to render it at once an example and fit instru- Qucbec Bill, ment for introducing the same absolute rule into these Colonies : — For taking away our Charters, abolishing our most valuable Laws, and altering Conn., R. I., fundamentally the Forms of our Governments. —— Mass., etc.

For suspending our own Legislatures, and declaring Legislatures themselves invested with power to legislate for us of Va., Mrd., in all eases whatsoever. He has abdicated $\mathrm{Ga.,}$. Y. Government here, by declaring us out of his Protec- Arrival of tion and waging War against us: - - He has plun- Gage and dered our seas, ravaged our Coasts, burnt our towns, Borces in 
Lexington, and destroyed the lives of our people. $\mathrm{He}$ is all Concord, and this time transporting large Armies of foreign MerBunker Hill.

Hessian soldiers. cenaries to compleat the works of death, desolation and tyranny, already begun with eircumstances of Cruelty \& perfidy scarcely paralleled in the most barbarous ages, and totally unworthy the Head of

This grierance was not settled until the War of 1812 .

The Continental Congress had also raised Indians to fight the British, 1775.

Va. Resolutions 1765, Declaration of Rights and Grievances, 1765 .

Address to the People of Great Britain.

Statement of Independence. a civilized nation. - He has constrained our fellow Citizens taken Captive on the high Seas to bear Arms against their Country, to become the executioners of their friends and Brethren, or to fall themselves by their Hands. - - He has excited domestic insurrections amongst us, and has endeavoured to bring on the inhabitants of our frontiers, the merciless Indian Savages, whose known rule of warfare, is an undistinguished destruction of all ages, sexes and conditions. - In every stage of these Oppressions We have Petitioned for Redress in the most humble terms: Our repeated Petitions have been answered only by repeated injury. A Prince, whose character is thus marked by every act which may define a 'Tyrant, is unfit to be the ruler of a free People. — Nor hare We been wanting in attention to our Brittish brethren. We have warned them from time to time of attempts by their legislature to extend an unwarrantable jurisdiction over us. We have reminded them of the circumstanees of our emigration and settlement here. We have appealed to their native justice and magnanimity, and we have conjured them by the ties of our common kindred to disavow these usurpations, which, would inevitably interrupt our connections and correspondence. They too have been deaf to the voice of justice and of consanguinity. We must, therefore, acquiesce in the necessity, which denounces our Separation, and hold them, as we hold the rest of mankind, Fnemies in War, in Peace Friends.

We, therefore, the Representatives of the united States of America, in General Congress, Assembled, appealing to the Supreme Judge of the world for 
the rectitude of our intentions, do, in the Name, and by Authority of the good People of these Colonies, solemnly publish and declare, That these United Colonies are, and of Right ought to be Free and Independent States; that they are Absolved from all Allegiance to the British Crown, and that all political connection between them and the State of Great Britain, is and ought to be totally dissolved; and that as Free and Independent States, they have full Power to levy War, conclude Peace, contract Alliances, establish Commerce, and to do all other Acts and Things which Independent States may of right do. - And for the support of this Declaration, with a firm reliance on the protection of divine Providence, we mutually pledge to each other our Lives, our Fortunes and our sacred Honour.

\section{JOHN HANCOCK}

New Hampshive - Josiah Bartlett, Wr. The names Whipple, Marthew Thorvton.

Massachusetts Bay - SAML. Adaus, JoHy ers are here Adams, Robt. Treat Paine, Eldridge Gerry. the original.

Rhode Island - Step. Hopkins, WilliaM of the states ElLery. Connecticut - Roger Sherman, Sam'el Hun- grouping is tington, Wu. Willians, Oliver Wolcott. the same,

New York - Wr. Floyd, Phil. Livingston, excepting Frans. Lewis, Lewis Morris.

New Jersey - Ricid. Stockton, Jno. Witherspoon, Fras. Hópinson, Join Hart, Abra. Clark.

Pennsylvania - RoBt. Morris, B E x J A I N Rush, Benja Franklin, John Mortov, Geo, nal docuClymer, Jas. Smitil, Geo. Taylor, James Wilson, Geo. Ross.

Delaware - Cefsar Rodney, Geo. Read, Tio. M'KeAN.

Maryland - Sameel Chase, Wm. Paca, Thos. Stone, Cirarles Carroll of Carrollton.

Virginia - George Wythe, Richard Henry Lee, Th. Jefferson, Benja. Harrison, Thos. 
Nelson, jr., Francis Lightfoot Lee, Carter Braxtox.

North Carolina - WM. Hooper, JosepH Hewes, John Pens.

South Carolina - Edwand RUthedge, 'Thos. Hexward, Junr., Thomas Lynch, Junr., Arthur Middleton.

Georgia - Butron Gwinnett, Lyman Hall, Geo. Waltow.

\title{
CONTEMPORARY EXPOSITION
}

\author{
JOHN ADAMS (1776) \\ Joinn Adams to Mrs. Adays
}

Philadelphir July 3 [morning], 1776.

Your favour of June 17, dated at Plymouth, was handed me yesterday by the post. I was much pleased to find that you had taken a journey to Plymonth to see your friends, in the long absence of one whom you may wish to see. The excursion will be an amusement, and will serve your health. How happy would it have made me to have taken this journey with you!

Yesterday the greatest question was decided which ever was debated in America; and a greater, perhaps, never was or will be decided among men. A resolution was passed, without one dissenting colony :

"That these United Colonies are, and of right ought to be, free and independent states; and, as free and independent states, they have, and of right ought to have, full power to make war, conclude peace, establish commerce, and to do all other acts and things which other states may rightfully do."

You will see, in a few days, a declaration, setting forth the canses which have impelled us to this revolution, and the reasons which will justify it in the sight of God and man. A plan of confederation will be taken up in a few days.

When I look back to the year 1761 , and recollect the argument concerning writs of assistance, in the superior court, which I have hitherto considered as the commencement of the controversy between Great Britain and America, and run 
through the whole period from that time to this, and recollect the series of political events, the chain of causes and effects, I am surprised at the suddenness as well as greatness of this revolution.

Britain has been filled with folly, and America with wisdom; at least this is my judgment - time must determine. It is the will of Heaven that the two countries should be sundered forever. It may be the will of Heaven that America shall suffer calamities still more wasting, and distresses still more dreadful. If this is to be the case, it will have this good effect at least, it will inspire us with many virtues which we bave not, and correct many errors, follies, and vices, which threaten to disturb, dishonour, and destroy us. The furnace of affliction produces refinement in states as well as individuals. And the new governments we are assuming in every part, will require a purification from our vices, and an augmentation of our virtues, or they will be no blessings. The people will have unbounded power; and the people are extremely addicted to corruptiou and venality, as well as the great. I am not withont apprehensions from this quarter; but I must submit all my hopes and fears to an over ruling Providence, in which, unfashionable as it may be, I firmly believe.

John Adays.

\section{John Adams to Mrs. Adams.}

Philadelphia, July 3 [evening], 1776.

Had a Declaration of Independence been made seven months ago, it would have been attended with many great and glorious effects. We might, before this hour, have formed alliance with foreign states. We should have mastered Quebec, and been in possession of Canada.

You will, perhaps, wonder how such a declaration wonld have influenced our affairs in Canada; but, if I could write with freedom, I could easily convince you that it would, and explain to you the manner how. Many gentlemen in high stations, and of great influence, have been duped, by the ministerial bubble of commissioners, to treat; and, in real, sincere expectation of this event, which they so fondly wished, they have been slow and languid in promoting measures for the re- 
duction of that province. Others there are in the colonies, who really wished that our enterprise in Canada would be defeated; that the colonies might be brought into danger and distress between two fires, and be thus induced to submit. Others really wished to defeat the expedition to Canada, lest the conquest of it should elerate the minds of the people too much to hearken to those terms of reconciliation which they believed would be offered us. These jarring views, wishes, and designs, occasioned an opposition to many salutary measures which were proposed for the support of that expedition, and caused obstructions, embarrassments, and studied delays, which have finally lost us the province.

All these causes, however, in conjunction, would not have disappointed us, if it had not been for a misfortune which could not have been foreseen, and perhaps could not have been prevented - I mean the prevalence of the smallpox among our troops. This fatal pestilence completed our destruction. It is a frown of Providence upon us, which we ought to lay to heart.

But, on the other hand, the delay of this declaration to this time has many great advantages attending it. The hopes of reconciliation which were fondly entertained by multitudes of honest and well meaning, though short-sighted and mistaken people, have been gradually, and at last totally, extinguished. Time has been given for the whole people maturely to consider the great question of independence, and to ripen their judgment, dissipate their fears, and allure their hopes, by discussing it in newspapers and pamphlets - by debating it in assemblies, conventions, committees of safety and inspection - in town and county meetings, as well as in private conversations; so that the whole people, in every colony, have now adopted it as their own act. This will cement the union, and avoid those heats, and perhaps convulsions, which might have been occasioned by such a declaration six months ago.

But the day is past. The second day of July, 1776, will be a memorable epocha in the history of America. I am apt to believe that it will be celebrated by succeeding generations, as the great Anniversary Festival. It ought to be commemorated, as the day of deliverance by solemn acts of devotion to Grod Almighty. It ought to be solemnized with pomp, shews, games, 
sports, guns, bells, bonfires and illuminations, from one end of the continent to the other, from this time forward forever.

You will think me transported with enthusiasm; but I am not. I am well aware of the toil, and blood, and treasure, that it will cost us to maintain this declaration, and support and defend these states. Yet, through all the gloom, I can see the rays of light and glory; I can see that the end is more than worth all the means, and that posterity will triumph, although you and I may rue, which I hope we shall not.

Jolln ADAMs.

John Adams and Mrs. Abigall Adams, Familiar Letters during the Revolution. 105, 106.

\section{RAMSAY (1777)}

The eagerness for independence resulted more from fecling than reasoning. The advantages of an unfettered trade, the prospect of honours and emoluments in administering a new government, were of themselves insufficient motives for adopting this bold measure. But what was wanting from considerations of this kind, was made up by the persererance of Great Britain, in her schemes of coercion and conquest. The determined resolution of the mother eountry to subdue the colonists, together with the plans she adopted for accomplishing that purpose, and their equally determined resolution to appeal to Heaven rather than submit, made a declaration of independence as necessary in 1776 , as was the non-importation agreement of 1774 , or the assumption of arms in 1775 . The last naturally resulted from the first. The revolution was not forced on the people by ambitious leaders grasping at supreme power, but every measure of it was forced on Congress, by the necessity of the case, and the voice of the people. The change of the public mind of America respecting connexion with GreatBritain, is without a parallel. In the short space of two years, nearly three millions of people passed over from the love and duty of loyal subjects, to the hatred and resentment of enemies.

Raмsıx, American Revolution. I. 430-432. 


\section{JEFFERSON (1821)}

Congress proceeded the same day to consider the Declaration of Independence, which had been reported and lain on the table the Friday preceding, and on Monday referred to a committee of the whole. The pusillanimous idea that we had friends in England worth keeping terms with, still haunted the minds of many. For this reason, those passages which conveyed censures on the people of England were struck out, lest they should give them offence. The clause, too, reprobating the cnslaving the inhabitants of Africa, was struck out in complaisance to South Carolina and Georgia, who had never attempted to restrain the importation of slaves, and who, on the contrary, still wished to continue it. Our Northern brethren also, I believe, felt a little tender under those censures; for though their people had very few slaves themselves, yet they had been pretty considerable carriers of them to others. The debates, having taken up the greater parts of the $2 \mathrm{nd}, 3 \mathrm{rd}$, and 4 th days of July, were, on the evening of the last, closed; the Declaration was reported by the committee, agreed to by the House, and signed by every member present, except Mr. Dickinson.

Thomas Jefferson, Works. I. 19.

\section{CRITICAL COMMENT}

WEBSTER (1826)

The Congress of the Revolution, fellow-citizens, sat with closed doors, and no report of its debates was ever made. The discussion, therefore, which accompanied this great measure, has never been preserved, except in memory and by tradition. . . . If we contemplate it from the point where they then stood, no question could be more full of interest; if we look at it now, and judge of its importance by its effects, it appears of still greater magnitude.

Let us, then, bring before us the assembly, which was about to decide a question thus big with the fate of empire. Let us open their doors and look in upon their deliberations. Let us survey the anxions and care-worn conntenances, let us hear the firm-toned voices, of this band of patriots. 
Haxcock presides over the solemn sitting; and one of those not yet prepared to pronounce for absolute independence is on the floor, and is urging his reasons for dissenting from the declaration.

"Let us pause! This step, once taken, cannot be retraced. This resolution, once passed, will cut off all hope of reconciliation. If success attend the arms of England, we shall then be no longer Colonies, with charters and with privileges; these will all be forfeited by this act; and we shall be in the condition of other conquered people, at the mercy of the conquerors. For ourselves, we may be ready to run the hazard; but are we ready to carry the country to that length? Is success so probable as to justify it? Where is the military, where the naval power, by which we are to resist the whole strength of the arm of England, for she will exert that strength to the utmost? Cau we rely on the constancy and perseverance of the people? or will they not act as the people of other countries have acted, and, wearied with a long war, submit in the end to a worse oppression? While we stand on our old ground, and insist on redress of grievances, we know we are right, and are not answerable for consequences. Nothing, then, can be imputed to us. But if we now change our object, carry our pretensions farther, and set up for absolute independence, we shall lose the sympathy of mankind. We shall no longer be defending what we possess, but struggling for something which we never did possess, and which we have solemnly and uniformly disclaimed all intention of pursuing, from the very outset of the troubles. Abandoning thus our old ground, of resistance only to arbitrary acts of oppression, the nations will believe the whole to have been mere pretence, and they will look on us, not as injured, but as ambitious subjects.

"I shudder before this responsibility. It will be on us, if, relinquishing the ground on which we have stood so long, and stood so safely, we now proclaim independence, and carry on the war for that object, while these cities burn, these pleasant fields whiten and bleach with the bones of their owners, and these streams run blood. It will be upon us, it will be upon us, if, failing to maintain this unseasonable and ill-judged declaration, a sterner despotism, maintained by military power, shall 
be established over our posterity, when we ourselves, given up by an exhausted, a harassed, a misled people, shall have expiated our rashuess and atoned for our presumption on the scaffold."

It was for Mr. Adams to reply to arguments like these. We know his opinions, and we know his character. He would commence with his accustomed directness and earnestness.

"Sink or swim, live or die, survive or perish, I give my hand and my heart to this vote. It is true, indeed, that in the beginning we aimed not at independence. But there's a Divinity which shapes our ends. The injustice of England has driven us to arms; and, blinded to her own interest for our good, she has obstinately persisted, till independence is now within our grasp. We have but to reach forth to it, and it is ours. Why, then, should we defer the Declaration? Is any man so weak as now to hope for a reconciliation with England, which shall leave either safety to the country and its liberties, or safety to his own life and his own honour? Are not you, Sir, who sit in that chair, is not he, our venerable colleague near you, are you not both already the proscribed and predestined objects of punishment and of vengeance? Cut off from all hope of royal clemency, what are you, what can you be, while the power of England remains, but outlaws? If we postpone independence, do we mean to carry on, or to give up, the war? Do we mean to submit to the measures of Parliament, Boston Port Bill and all? Do we mean to submit, and consent that we ourselves shall be ground to powder, and our country and its rights troddeu down in the dust? I know we do not mean to submit. We never shall submit. Do we intend to violate that most solemn obligation ever entered into by men, that plighting, before God, of our sacred honour to Washington, when, putting him forth to incur the dangers of war, as well as the political hazards of the times, we promised to adhere to him, in every extremity, with our fortunes and our lives? I know there is not a man here, who would not rather see a general conflagration sweep over the land, or an earthquake sink it, than one jot or tittle of that plighted faith fall to the ground. For myself, having, twelve months ago, in this place, moved you, that Greorge Washington be appointed com- 
mander of the forces raised, or to be raised, for defence of American liberty, may my right hand forget her cunning, and iny tongue cleave to the roof of my mouth, if I hesitate or waver in the support I give him.

"'The war, then, must go on. We must fight it through. And if the war must go on, why put off longer the Declaration of Independence? That measure will strengthen us. It will give us character abroad. The nations will then treat with us, which they never can do while we acknowledge ourselves subjects, in arms against our sovereign. Nay, I maintain that England herself will sooner treat for peace with us on the footing of independence, than consent, by repealing her acts, to acknowledge that her whole conduct towards us has been a course of injustice and oppression. Her pride will be less wounded by submitting to that course of things which now predestinates our independence, than by yielding the points in controversy to her rebellious subjects. The former she would regard as the result of fortune; the latter she would feel as her own deep disgrace. Why, then, why, then, Sir, do we not as soon as possible change this from a civil to a national war? And since we must fight it through, why not put ourselves in a state to enjoy all the benefits of victory, if we gain the victory?

"If we fail, it can be no worse for us. But we shall not fail. The cause will raise up armies; the cause will create navies. The people, the people, if we are true to them, will carry us, and will carry themselves, gloriously, through this struggle. I care not how fickle other people have been found. I know the people of these Colonies, and I know that resistance to British aggression is deep and settled in their hearts and cannot be eradicated. Every Colony, indeed, has expressed its willingness to follow, if we but take the lead. Sir, the Declaration will inspire the people with increased courage. Instead of a long and bloody war for the restoration of privileges, for redress of grievances, for chartered immunities, held under a British lking, set before them the glorious object of entire independence, and it will breathe into them anew the breath of life. Read this Declaration at the head of the army; every sword will be drawn from its scabbard, and the solemn vow uttered, to maintain it, or to perish on the bed of honor. Pub- 
lish it from the pulpit; religion will approve it, and the love of religious liberty will cling rouud it, resolved to stand with it, or fall with it. Send it to the public halls ; proclaim it there; let them hear it who heard the first roar of the enemy's cannon; let them see it who saw their brothers and their sons fall on the field of Bunker Hill, and in the streets of Lexington and Concord, and the very walls will cry out in its support.

"Sir, I know the uncertainty of human affairs, but I see, I see clearly, through this day's business. You and I, indeed, may rue it. We may not live to the time when this Declaration shall be made good. We may die; die colonists; die slaves; die, it may be, ignominiously and on the scaffold. Be it so.

" Be it so. If it be the pleasure of Heaven that my country shall require the poor offering of my life, the victim shall be ready, at the appointed hour of sacrifice, come when that hour may. But while I do live, let me have a country, or at least the hope of a country, and that a free country.

"But whatever may be our fate, be assured, be assured that this Declaration will stand. It may cost treasure, and it may cost blood; but it will stand, and it will richly compensate for both. Through the thick gloom of the present I see the brightness of the future, as the sun in heaven. We shall make this a glorious, an immortal day. When we are in our graves, our children will honour it. They will celebrate it with thanksgiving, with festivity, with bonfires, and illuminations. On its annual return they will shed tears, copious, gushing tears, not of subjection and slavery, not of agony and distress, but of exultation, of gratitude, and of joy. Sir, before God, I believe the hour is come. My judgment approves this measure, and my whole heart is in it. All that $I$ have, and all that $I$ am, and all that I hope, in this life, I am now ready here to stake upon it; and I leave off as I begun, that live or die, survive or perish, I am for the Declaration. It is my living sentiment, and by the blessing of God it shall be my dying sentiment, Independence, now, and INDEPENDENCE FOR EVER."

Danifil Webster, Works. I. 130-136 
STORY (1833)

From the moment of the declaration of independence, if not for most purposes at an antecedent period, the united colonies must be considered as being a nation de facto, having a general government over it, created, and acting by the general consent of the people of all the colonies. The powers of that government were not, and indeed could not be well defined. But still its exclusive sorereignty, in many cases, was firmly established, and its controlling power over the states was in most, if not in all national measures, universally admitted.

Story, Constitution of the United States. II. 89.

LIVERMORE (1862)

The primal American Magna Charta, by which the Founders of the Republic asserted the right of the people to form a constitution and government of their own, was proclaimed on the 4th of July, 1776. Its language is clear and explicit. The authors were men of sense and of learning. They knew the meaning of the words they used. Was it for "glittering generalities" that they pledged their lives, their fortunes, and their sacred honor, or did they regard the sentiments of that immortal document as solemn verities? In those times which tried men's souls, were they guilty of attempting to amuse the fancy by a rhetorical flourisl, or, what is worse, to delude their fellow-citizens by the merest cant, or did they intend deliberately and reverently to publish to the world their Political Confession of Faith, and to endeavour to show that faith by their works?

George Livermore, An Historical Research. 19.

\section{J. R. GREEN (1874)}

Washington more than any of his fellow colonists represented the clinging of the Virginia land-owners to the mothercountry, and his acceptance of the command of the continental army proved that even the most moderate among them had no hope now save in arms. . . The colonies of the south, the last to join the struggle, had, in fact, expelled their governors in 1775. 'These decisive steps were followed by the great act 
with which American history begins, the adoption on the 4 th of July, 1776, by the delegates in Congress of a Declaration of Independence.

J. R. Green, Short History of the English People. 779, 780.

\section{VON HOLST (1875)}

The individual colonies, on the other hand, considered themselves, up to the time of the Declaration of Independence, as legally dependent upon England and did not take a single step which could have placed them before the mother country or the world in the light of de facto so vereign states. They remained colonies until the " representatives of the United States" " in the name of the good people of these colonies" solemnly declared "these united colonies" to be "free and independent states." The transformation of the colonies into "states" was, therefore, not the result of the independent action of the individual colonies. It was accomplished through the " representatives of the ['nited States," that is, through the revolutionary congress, in the name of the whole people. Each individual colony became a state only in so far as it belonged to the United States, and in so far as its population constituted a part of the people. The thirteen colonies did not, as thirteen separate and mutually independent commonwealths enter into a compact to sever the bonds which connected them with their common mother country, and at the same time to proclaim the act in a common manifesto to the world; but the "one people" of the united colonies dissolved that political connection with the English nation, and proclaimed themselves resolved, henceforth, to constitute the one perfectly independent people of the United States. The Declaration of Independence did not create thirteen sovereign states, but the representatives of the people declared that the former English colonies, under the name which they had assumed of the United States of America, became, from the fourth day of July, 1776, a sovereign state and a member of the family of nations, recognized by the law of nations; and further, that the people would support their representatives with their blood and treasure, in their endeavour to make this declaration a universally recognized fact. Neither congress nor the people relied in this upon any positive 
right belonging either to the individual colonies or to the colonies as a whole. Rather did the Declaration of Independence and the war destroy all existing political jural relations, and seek their moral justification in the right of revolution inherent in every people in extreme emergencies.

Dr. H. von Hotst, The Constitutional History of the United States. I. 5-7.

\section{LECKY (1882)}

The petition of Congress to the King, which was the last serious effort of America for pacification, was duly taken over to England; but, after a short delay, Lord Dartmouth informed the delegates that ' no answer would be given to it.' An Act of Parliament was passed authorizing the confiscation of all American ships and cargoes, and of all vessels of other nations trading with the American ports; and by a clause of especial atrocity, the commanders of the British ships of war were empowered to seize the crews of all American vessels, and compel them, under pain of being treated as mutineers, to serve against their countrymen.

All these things contributed to sever the colonies from amicable connection with England, and to make the prospect of reconciliation appear strange and remote. Separation, it was plausibly said, was the act of the British Parliament itself, which had thrown the thirteen colonies out of the protection of the Crown. But another and more practical consideration concurred with the foregoing in producing the Declaration of Independence. One of the gravest of the questions which were agitating the Revolutionary party was the expediency of asking for foreign, and especially for French assistance. France had hitherto been regarded in America, even more than in England, as a natural enemy. She was a despotic Power, and could not therefore, have much real sympathy with a struggle for constitutional liberty. Her expulsion from America had been for generatious one of the first objects of American patriots; and if she again mixed in American affairs, it was natural that she should seek to regain the province she had so lately lost. If America was destined to be an independent Republic, nothing could be more dangerous than to have a military and aggressive colony belonging to the most powerful despotism in Europe 
planted on her frontiers. . . The questions of a French alliance and of a declaration of independence were thus indissolubly connected. In the autumn of 1775 a motion was made in Congress, and strongly supported by John Adams, to send ambassadors to France. But Congress still shrank from so formidable a step, though it agreed, after long debates and besitation, to form a secret committec 'to correspond with friends in Great Britain, Ireland, and other parts of the world.'

... It belongs rather to the historian of America than to the historian of England to recount in detail the various steps that led immediately to the Declaration of Independence. . . . John Adams was now the most powerful advocate, while John Dickenson was the chief opponent of independence. At last, however, it was resolved not to show any appearance of dissension to the world. . . Thomas Jefferson, of Virginia, whose literary power had been shown in many able State papers, had already drawn up the Declaration of Independence, which, having been revised by Franklin and by John Adams, was now submitted to the examination of Congress, and was voted after some slight changes on the evening of the 4th. It proclaimed that a new nation had arisen in the world, and that the political unity of the English race was for ever at an end.

W. E. H. LECKY, England in the Eighteenth Century. III. 491-499.

ELLIS (1887)

Recalling the fact that in all previons remonstrances and petitions, without a single exception, whether coming from a convention, an assembly, or a congress, the ministry and Parliament were made to bear the burden of all complaints and reproaches, we note with emphasis that in the Declaration of Independence, for the first time, "the present king of Great Britain" is charged the offender. Its scathing invectives in its short sentences begin with "He." His tools and supporters are all lost sight of, passed unmentioned. This substitution of the monarch himself as ehargeable, through his own persistency, with the whole burden heretofore laid at the door of his advisers indicates the necessity which Congress felt of seeming to sever 
their plain constitutional allegiance to the monarch, and of ignoring all dependence on his ministers or Parliament, whose supremacy over the colonies they had always denied. Hence the tone and wording of all the previous utterances of Congress, deferential and even fulsome as they now seem, in sparing the king, for the first time, in the Declaration, are changed to give the necessary legal emphasis of the capital letters in He. . . .

On the other side of the water, the Declaration, as " throwing off the mask of hypocrisy" by the patriots, was a very painful shock to many who had been most friendly and earnest champions of the cause of the colonists. The memhers of the opposition in Parliament and in high places were taunted by the supporters of Government for all their pleading in behalf of rebels. And when, besides the bold avowal of independence, the added measures of a suspension of all commerce with Great Britain, and an alliance of the patriots with the liereditary enemy of their mother country, came to the knowledge of those who had been our friends, the consternation which it caused them was but natural. . . . What is there to be said, either by way of explanation or of justification, of the course ascribed to the patriots? It is well to admit freely that there was much said, if not done, that had the seeming of duplicity and insincerity, of secrecy of design and of sinuous dealing. And after yielding all that can be charged of this, we may insist that, in reality, it was nothing beyond the seeming. Neither disguise, nor duplicity, nor hypocrisy, nor artful or cunning intrigue, in any shape or degree, was availed of by the patriots. The result to which they were led was from the first natural and inevitable, and it was reached by bold and honest stages, in thinking ont and making sure of their way. The facts are all clearly revealed to us in their course of development. The maturing of opinion, till what had been repelled as a calamity was accepted as a necessity, is traceable through the changing events of a few heavily burdened years, if not even of months and days, to say nothing of the symptoms of it which a keen perception may discover during the career of four generations of Englishmen on this continent. Its own natural stages of growth were reached just at the time that it was attempted to bring it under check by artificial restraint of the home government. 
That government compelled the colonists to ask themselves the two questions: first, if they were anything less than Englishmen; and further, if their natural rights were any less than those of men.

George E. Elris, in Winsor, Narrative and Critical History of America. VI. 247.

\section{FISKE (1896)}

No one who is familiar with the essential features of American political life can for a moment suppose that the Declaration of Independence was brought about by any less weighty force than the settled conviction of the people that the priceless treasure of self-government could be preserved by no other means. It was but slowly that this unwelcome conviction grew upon the people; and owing to local differences of circumstances it grew more slowly in some places than in others. Prescient leaders, too, like the Adamses and Franklin and Lee, made up their minds sooner than other people. Even those conservatives who resisted to the last, even such men as Johı Dickinson and Robert Morris, were fully agreed with their opponents as to the principle at issue between Great Britain and America, and nothing would have satisfied them short of the total abandonment by Great Britain of her pretensions to in!pose taxes and revoke charters. Upon this fundamental point there was very little difference of opinion in America. As to the related question of independence, the decision, when once reached, was everywhere alike the reasonable result of free and open discussion; and the best possible illustration of this is the fact that not even in the darkest days of the war already begun did any state deliberately propose to reconsider its action in the matter.

Johx Frske, American Revolution. I. 196.

\section{LODGE (1899)}

The Declaration when published was read to the army under Washington and received by the soldiers with content. It was a satisfaction to them to have the reality for which they were fighting put into words and oflicially declared. It was read also formally and with some ceremony in public places, in all 
the chief towns of the colonies, and was received by the people cordially and heartily, but without excitement. There was no reason why it should have called forth much feeling, for it merely embodied public opinion already made up, and was expected by the loyalist minority. Yet despite its general acceptance, which showed its political strength, it was a great and memorable document. From that day to this it has been listened to with reverence by a people who have grown to be a great nation, and equally from that day to this it has been the subject of severe criticism. The reverence is right, the criticism misplaced and founded on misunderstanding.

Hexry Cabot Lodge, American Revolution. I. 499. 


\section{CHAPTER XV \\ THE ARTICLES OF CONFEDERATION}

\section{SUGGESTIONS}

From July 4th, 1776, the United States of America were governed by a Continental or General Congress until March 1, 1781, when the States adopted a constitution, called the "Articles of Confederation and Perpetual Union between the States." The "Articles " had been made by the States only: Congress continued to govern or pretended to govern by these "Articles" until March 4th, 1789: but in the meanwhile the constitution had no given power to execute the laws or to pass judgment upon the acts of the government. The document is supposed to have been drafted by John Dickinson of Delaware, but as the work of the committee was done in secret and has never been reported the point cannot be determined.

The inadequacy of this frame of government proved to be most unsatisfactory. Five years of construction, six years of struggling existence, mark the life of the Articles, but they died only to give birth to a greatly improved constitutional document.

For Outlines and Material, see Appendix B.

\section{DOCUMENT}

Articles of Confederation (1776-1778)

Nov. 15, 1777. - ARTICLES AGREED TO BY CONGRESS

American A copy of the Confederation being made out History Leaflets No. 20 (verified and sundry amendments made in the diction without altering the sense the same was agreed to \& is from original as follows :

manu-

scripts).

Reported

July 8th, 1776.

Ratified

March 1st 1781.

\section{Joly 9, 1778. - ARTICLES OF CONFEDERA- TION. (OFFICIAI, ENGROSSED TEXT) Ta all to rearam}

these Presents shall come, we the undersigned Delegates of the States affixed to our Names send 
greeting. Whereas the Delegates of the United States of America in Congress assembled did on the fifteenth day of November in the Year of Our Lord One thousand seven Hundred and Seventyseven, and in the second Year of the Independenee of America agree to certain articles of Confederation and perpetual Union between the States of Newhampshire, Massachusetts-bay, Rhodeisland and Providence Plantations, Connecticut, New York, New Jersey, Pennsylvania, Delaware, Maryland, Virginia, North-Carolina, South-Carolina, and Georgia in the Words following, viz. "Articles of Confederation and perpetual Union between the States of Newhampshire, Massachusetts-bay, Rhodeisland and Providence Plantatious, Connecticut, New-York, New-Jersey, Pennsylvania, Delaware, Maryland, Virginia, North-Carolina, South-Carolina, and Georgia."

Article I. The Stile of this confederacy shall be "The United States of America."

Article II. Each state retains its sovereignty, Idea of freedom and independence, and every Power, Juris- statehood diction and right, which is not by this confederation foremost. expressly delegated to the United States, in Congress assembled.

Article III. The said states hereby severally See Constituenter into a firm league of friendship with each ${ }_{\text {Preamble. }}^{\text {tion; }}$ other, for their common defence, the security of their Liberties, and their mutual and general welfare, binding themselves to assist each other, against all force offered to, or attacks made upon them, or any of them, on account of religion, sovereignty, trade, or any other pretence whatever.

Article IV. Tine better to secure and perpetuate Notwithmutual friendship and intereourse among the people standing this of the different states in this union, the free in- ous states habitants of each of these states, paupers, vaga- disagreed bonds, and fugitives from Justice excepted, shall over trade be entitled to all privileges and immunities of free tion Laws. 
citizens in the several states; and the people of each state shall have free ingress and regress to and from any other state, and shall enjoy therein See Constitu- all the privileges of trade and commerce, subject tion, Art. $\mathbf{i}$. to the same duties, impositions and restrictions as 10 (2) the inhabitants thereof respectively, provided that such restriction shall not extend so far as to prevent the removal of property imported into any state, to any other state of which the Owner is an inhabitant; provided also that no imposition, duties or restriction shall be laid by any state, on the property of the united states, or either of them.

Constitution. IF any Person be guilty of, or charged with Art. iv. 2. (2) treason, felony, or other high misdemeanour in any state, shall flee from Justice, and be found in any of the united states, he shall upon demand of the Governor or executive power, of the state from which he fled, be delivered up and removed to the state having jurisdiction of his offence.

Constitution, Full faith and credit shall be given in each of Art. iv. 1 these states to the records, acts and juclicial proceedings of the courts and magistrates of every other state.

Since there was no separate executive or judiciary, Congress became the sole repository of national power. See Constitution, Art. i. 1-7

Constitution Art i. 2 $(1,2,3)$

Article V. For the more convenient management of the general interest of the united states, delegates shall be annually appointed in such manner as the legislature of each state shall direct, to meet in Congress on the first Monday in November, in every year, with a power reserved to each state, to recal its delegates, or any of them, at any time within the year, and to send others in their stead, for the remainder of the Year.

No state shall be represented in Congress by less than two, nor by more than seren Members; and no person shall be capable of being a delegate for more than three years in any term of six years : nor shall any person, being a delegate, be capable of holding any office under the united states, for 
which he, or another for his benefit, receives any salary, fees or emolument of any kind.

EACH state shall maintain its own delegates in a meeting of the states, and while they act as members of the committee of the states.

Is determining questions in the united states, in Congress assembled, each state shall have one vote.

Freedox of speech and debate in congress shall Constitution, not be impeached or questioned in any Court, or Art. i. 6 (1) place out of Congress, and the members of Congress shall be protected in their persons from arrests and imprisonments, during the time of their going to and from, and attendance on congress, except for treason, felony, or breach of the peace.

Article VI. No state without the Consent of Constitution, the united states in congress assembled, shall send Art. i. 10. any embassy to, or receive any embassy from, or enter into any conference, agreement, alliance or treaty with any King, prince, or state; nor shall any person holding any office of profit or trust under the united states, or any of them, accept of any present, emolument, office or title of any kind whatever from any king, prince, or foreign state; nor shall the united states in congress assembled, or any of them, grant any title of nobility.

No two or more states shall enter into any treaty, Notwithconfederation or alliance whatever between them, standing this without the consent of the united states in congress clamse, a assembled, specifying accurately the purpose for made be-

which the same is to be entered into and how long tween Maryit shall continue. Virginia.

No state shall lay any imposts or duties, which This crippled may interfere with any stipulations in treaties, en- the treatytered into by the united states in congress assem- making bled, with any king, prince, or state, in pursuance of any treaties already proposed by congress, to the courts of France and Spain.

No vessels of war shall be kept up in time of peace by any state, except such number only, as 
Constitution, shall be deemed necessary by the united states in Art. I. 10 (3).

Notwithstanding this clause Georgia made war and treaty with Creek Indians. congress assembled, for the defence of such state, or its trade; nor shall any body of forces be kept up by any state, in time of peace, except such number only, as in the judgment of the united states, in congress assembled, shall be deemed requisite to garrison the forts necessary for the defence of such state; but every state shall always keep up a well regulated and disciplined militia, sufficiently armed and accoutred, and shall provide and constantly have ready for use, in public stores, a due number of field pieces and tents, and a proper quantity of arms, ammunition and camp equipage.

No state shall engage in any war without the consent of the united states in congress assembled, unless such state be actually invaded by enemies, or shall have received certain advice of a resolution being formed by some nation of Indians to invade such state, and the danger is so imminent as not to admit of a delay, till the united states in congress assembled can be consulted: nor shall any state grant commissions to any ships or vessels of war, nor letters of marque or reprisal, except it be after a declaration of war by the united states in congress assembled, and then only against the kingdom or state and the subjects thereof, against which war has been so declared, and under such regulations as shall be established by the united states in congress assembled, unless such state be infested by pirates, in which case vessels of war may be fitted out for that occasion, and kept so long as the danger shall continue, or until the united states in congress assembled shall determine otherwise.

Article VII. When land-forces are raised by any state for the common defence, all officers of or under the rank of colonel, shall be appointed by the legislature of each state respectively by whom such forces shall be raised, or in such manner as such state shall direct, and all vacancies 
shall be filled up by the state which first made the appointment.

Article VIII. All charges of war, and all other The system expences that shall be incurred for the common defence or general welfare, and allowed by the united states in congress assembled, shall be defrayed out of a common treasury. which shall be led supplied by the several states, in proportion to the value of all land within each state, granted to or surveyed for any Person, as such land and the buildings and improvements thereon shall be estimated according to such mode as the united states i. 8(1) of requisitions on the States proved totally inadequate, and led to conin congress assembled, shall, from time to time, direct and appoint. The taxes for paying that proportion shall be laid and levied by the authority and direction of the legislatures of the several states within the time agreed upon by the united states in congress assembled.

Article IX. The united states in congress as- Increase of sembled, shall have the sole and exclusive right and power in power of determining on peace and war, except in Congress in the cases mentioned in the sixth article - of sending Art. i. 8 (11and receiving ambassadors - entering into treaties 18). and alliances, provided that no treaty of commerce shall be made whereby the legislative power of the respective states shall be restrained from imposing such imposts and duties on foreigners, as their own people are subjected to, or from prohibiting the exportation or importation of any species of goods or commodities whatsoever - of establishing rules for deciding in all cases, what captures on land or water shall be legal, and in what manner prizes taken by land or naval forces in the service of the united states shall be divided or appropriated - of granting letters of marque and reprisal in times of peace - appointing courts for the trial of piracies and felonies committed on the high seas and establishing courts for receiving and determining finally appeals in all cases of captures, provided that no 
member of congress shall be appointed a judge of any of the said courts.

Constitution THE united states in congress assembled shall Art. iii.

This was a clumsy method and was used but once. also be the last resort on appeal in all disputes and differences now subsisting or that hereafter may arise between two or more states concerning boundary, jurisdiction or any other cause whatever ; which authority shall always be exercised in the manner following. Whenever the legislative or executive authority or lawful agent of any state in controversy with another shall present a petition to congress, stating the matter in question and praying for a hearing, notice thereof shall be given by order of congress to the legislative or executive anthority of the other state in controversy, and a day assigned for the appearance of the parties by their lawful agents, who shall then be directed to appoint by joint consent, commissioners or judges to constitute a court for hearing and determining the matter in question: but if they camnot agree, congress shall name three persons out of each of the united states, and from the list of such persons each party shall alternately strike out one, the petitioners beginning, until the number shall be reduced to thirteen; and from that number not less than seven, nor more than nine names as congress shall direct, shall in the presence of congress be drawn out by lot, and the persons whose names shall be so drawn or any five of them, shall be commissioners or judges, to hear and finally determine the controversy, so always as a major part of the judges who shall hear the cause shall agree in the determination : and if either party shall neglect to attend at the day appointed, without shewing reasons, which congress shall judge sufficient, or being present shall refuse to strike, the congress shall proceed to nominate three persons out of each state, and the secretary of congress shall strike in behalf of such party absent or refusing; and the judgment and sentence of the court to be 
appointed, in the manner before prescribed, shall be final and conclusive; and if any of the parties shall refuse to submit to the authority of such court, or to appear or defend their claim or cause, the court shall nevertheless proceed to pronounce sentence, or judgment, which shall in like manner be final and decisive, the judgment or sentence and other proceedings being in either case transmitted to congress, and lodged among the acts of congress for the security of the parties concerned: provided that every commissioner, before he sits in judgment, shall take an oath to be administered by one of the judges of the supreme or superior court of the state, where the cause shall be tried, "well and truly to hear and determine the matter in question, according to the best of his judgment, without favour, affection or hope of reward:" provided also that no state shall be deprived of territory for the benefit of the united states.

ALL controversies concerning the private right of Wyoming soil claimed under different grants of two or more Valley states, whose jurisdictions as they may respect such lands, and the states which passed such grants are adjusted, the said grants or either of them being at the same time claimed to have originated antecedent to such settlement of jurisdiction, shall on the petition of either party to the congress of the united states, be finally determined as near asmaybe in the same manner as is before prescribed for deciding disputes respecting territorial jurisdiction between different states.

The united states in congress assembled shall Paper money also have the sole and exclusive right and power of - Tender regulating the alloy and value of coin struck by Laws, Sharce's their own anthority, or by that of the respective Rebellion. states - fixing the standard of weights and measures throughout the United States - regulating the trade and manageing all affairs with the Indians, not members of any of the states, provided that the 
legislative right of any state within its own limits be not infringed or violated - establishing and regulating post-offices from one state to another, throughout all the united states, and exacting such postage on the papers passing thro' the same as may be requisite to defray the expences of the said office - appointing all oflicers of the land forces, in the service of the united states, excepting regimental officers - appointing all the officers of the naval forces, and commissioning all officers whatever in the service of the united states - making rules for the government and regulation of the said land and naval forces, and directing their operations.

This Committee of the

Tile united states in congress assembled shall States was a failure. have authority to appoint a committee, to sit in the recess of congress, to be denominated "A Committee of the States," and to consist of one delegate from each state; and to appoint such other committees and civil officers as may be necessary for manageing the general affairs of the united states under their direction - to appoint one of their number to preside, provided that no person be allowed to serve in the office of president more than one year in any term of three years; to ascertain the necessary sums of Money to be raised for the service of the united states, and to appropriate and apply the same for defraying the public expences - to borrow money, or emit bills on the credit of the united states, transmitting every half year to the respective states an account of the sums of money so borrowed or emitted, - to build and equip a navy to agree upon the number of land forces, and to make requisitions from each state for its quota, in proportion to the number of white inhabitants in such state; which requisition shall be binding, and thereupon the legislature of each state shall appoint the regimental officers, raise the men and cloath, arm and equip them in a soldier like manner, at the 
expence of the united states; and the officers and men so cloathed, armed and equipped shall march to the place appointed, and within the time agreed on by the united states in congress assembled: But Seditious if the united states in congress assembled shall, on consideration of circumstances judge proper that any state should not raise men, or should raise a smaller number than its quota, and that any other state should raise a greater number of men than the quota thereof, such extra number shall be raised, officered, cloathed, armed and equipped in the same manner as the quota of such state, unless the legislature of such state shall judge that such extra number cannot be safely spared out of the same, in which case they shall raise officer, cloath, arm and equip as many of such extra number as they judge ean be safely spared. Axp the officers and men so cloathed, armed and equipped, shall march to the place appointed, and within the time agreed on by the united states in congress assembled.

Tire united states in congress assembled shall The nine never engage in a war, nor grant letters of marque and reprisal in time of peace, nor enter into any treaties or alliances, nor coin money, nor regulate the value thereof, nor ascertain the sums and expences necessary for the defence and welfare of the united states, or any of them, nor emit bills, nor States rule (practically requiring a two-thirds vote of all the States) united states, or any of them, nor emit bills, nor needed
borrow money on the credit of the united states, legislation. nor appropriate money, nor agree upon the number of vessels of war, to be built or purchased, or the number of land or sea forces to be raised, nor appoint a commander-in-chief of the army or navy, unless nine states assent to the same: nor shall a question on any other point, except for adjourning from day to day be determined, unless by the votes of a majority of the united states in congress assembled.

The congress of the uniter states shall have 
power to adjourn to any time within the year, and to any place within the united states, so that no period of adjournment be for a longer duration than the space of six months, and shall publish the Journal of their proceedings monthly, except such parts thereof relating to treaties, alliances or military operations, as in their judgment require secrecy; and the yeas and nays of the delegates of each state on any question shall be entered on the Journal, when it is desired by any delegate; and the delegates of a state, or any of them, at his or their request shall be furnished with a transcript of the said Journal, except such parts as are above excepted, to lay before the legislatures of the several states.

Article X. The committee of the states, or any nine of them, shall be authorized to execute, in the recess of congress, such of the powers of congress as the united states in congress assembled, by the consent of nine states, shall from time to time think expedient to vest them with; provided that no power be delegated to the said committee, for the exercise of which, by the articles of confederation, the voice of nine states in the congress of the united states assembled is requisite.

Article XI. Canada acceding to this confederation, and joining in the measures of the united states, shall be admitted into, and entitled to all the advantages of this union: but no other colony shall be adinitted into the same, unless such admission be agreed to by nine states.

As the United States had no independent taxing powers, this clause was of very

Article XII. All bills of credit emitted, monies borrowed and debts contracted by, or under the authority of congress, before the assembling of the united states, in pursuance of the present confederation, shall be deemed and considered as a charge 
against the united states, for payment and satisfac- little action whereof the said united states, and the public count. faith are hereby solemnly pledged.

Article XIII. Every state shall abide by the This clause determinations of the united states in congress was conassembled, on all questions which by this confedera- broken tion are submitted to them. AxD the Articles of because of this confederation shall be inviolably observed by the central every state, and the union shall be perpetual; nor government. shall any alteration at any time hereafter be made in any of them; unless such alteration be agreed to in a congress of the united states, and be afterwards confirmed by the legislatures of every state.

And Uahereas it hath pleased the Great GoverNOR of the World to incline the hearts of the legislatures we respectively represent in congress, to approve of, and to authorize us to ratify the said articles of confederation and perpetual union. know ge 2 that we the undersigned delegates, by virtue of the power and authority to us given for that purpose, do by these presents, in the name and in behalf of our respective constituents, fully and entirely ratify and confirm each and every of the said articles of confederation and perpetual union, and all and singular the matters and things therein contained: Axp we do further solemuly plight and engage the faith of our respective constituents, that they shall abide by the determinations of the united states in congress assembled, on all questions, which by the said confederation are submitted to them. AND that the articles thereof shall be inviolably observed by the states we respectively represent, and that the union shall be perpetual. In wITNEss whereof we have hereunto set our hands in Congress. Done at Philadelphia in the state of Pennsylvania the ninth Day of July in the Year of our Lord one Thousaud seven Hundred and Seventy 
eight, and in the third year of the independence of America.

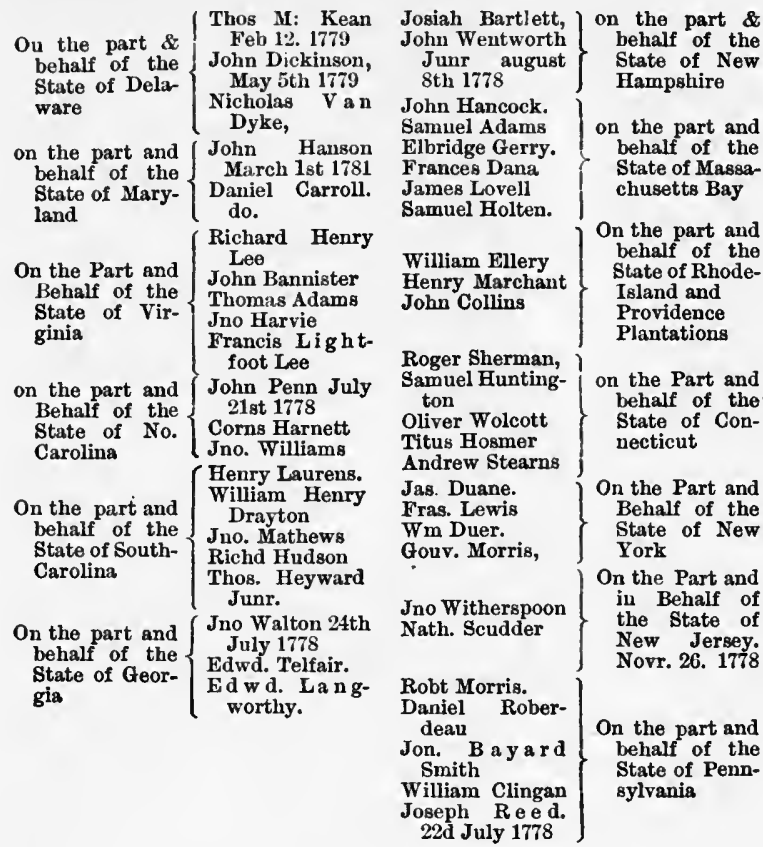

\section{CONTEMPORARY EXPOSITION}

PELATIAH WEBSTER (1784)

The articles of our federal union were drawn up by Congress, and adopted by the states, amirlst the confusions of a most bloody, cruel, and unnatural war, when the attention of Congress who drew, and the states who adopted them, was frequently drawn off by continual alarms, burning of towns, slaughter, and bloodshed. No marvel then that every inconviency attending them when reduced into practice, could not be foreseen, either by those who drew, or those who adopted them; at which period, it would not have been well accepted, had any one discovered, and had rentured to call into ques- 
tion, the propriety of any one of the thirteen articles of our confederation.

It may therefore be advisable, now that we are released of the distressing scenes of war, deliberately to examine, revise, correct and amend them, in every instance, in which when reduced into practice, they may be found - inconsistent with each other - not capable of being carried into execution - or inconsistent with the general sense and understanding of those who adopted them. ...

The true end and design of our confederation I take to be this, viz. To unite the strength of the separate states under Congress as their general Head, and to delegate to them the direction of the operations of our military and naval forces against the power of Great Britain. . . . And this I take it was the general sense and understanding of the states who adopted the articles of our federal union, and the whole tenor of the articles themselves support this opinion. . . . Congress are to determine the number of troops necessary for the service of the states. . . What service? The service of the war and general defence . . . and for that end they were to make requisition to each state for their quota, "and to ascertain the necessary sums of money to be raised for the service" of the war, and to appropriate and apply the same; that matter not being compatible to any particular state, by constitution is vested in congress, whose right it properly is, and is expressly delegated to them. . . .

The form of government planned by Congress, and adopted by the states, is the only form we could adopt under our circumstances: And the honor and dignity of Congress, as a private citizen, I am determined to support, as much as the sovereignty, freedom, and independence of the states, and every power, jurisdiction and right, which they have not expressly delegated to Congress. But as every deviation from the articles of our ferleral union makes a dangerous precedent in future, the defects in the articles of confederation can be known only by practice: And it is time enough to make alterations in our system of government, when the defects are made evident.

Pelatian Wenstir, liemarks On a Pampllet. 11, 24, 39. 
WASHINGTON (1786-1787)

To Henry Lee, in Congress.

Mt. Vernon, 31 October, 1786.

My Dear Sir, . . . Influence is no government. Let us have one by which our lives, liberties, and properties will be secured, or let us know the worst at once. Under these impressions, my humble opinion is, that there is a call for decision. . . . Let the reins of government then be braced and held with a steady hand, and every violation of the constitution be reprehended. If defective, let it be amended, but not suffered to be trampled upon whilst it has an existence. . . .

To John Gay.

10 March 1787.

Dear Sir, . . How far the revision of the federal system, and giving more adequate powers to congress may be productive of an efficient government, I will not under my present view of the nature, presume to decide. . . A Among men of reflection, few will be found I believe, who are not beginning to think that our system is more perfect in theory than in practice; and that notwithstanding the boasted virtne of America it is more probable we shall exhibit the best melancholy proof, that mankind are competent to their own government without the means of coercion in the sovereign. . . .

To James Madison, in Congress.

31 March, 1787.

Mr Dear Sir, . . . That a thorough reform of the present system is indispensable, none, who have capacities to judge, will deny; and with hand [and heart] I hope the business will be essayed in a full convention. After which, if more powers and more decision is not found in the existing form, if it still wants energy and that secrecy and despatch . . . which is characteristic of good government, and if it shall be found, . . . that Congress will, upon all proper occasions, exert the powers which are given, with a firm and steady hand, instead of frittering them back to the States, where the members, in place of viewing themselves in their national character, are too apt to be looking, - I say, after this essay is made, if the system 
proves inefficient, conviction of the necessity of a change will be disseminated among all classes of the people. Then, and not till then, in my opinion, can it be attempted without involving all the evils of civil discord. . . .

George Washington, Works. II. 76-133.

\section{HAMILTON (1780)}

But the Confederation itself is defective, and requires to be altered. It is neither fit for war nor peace. The idea of an uncontrollable sovereignty in each State over its internal police will defeat the other powers given to Congress, and make our union feeble and precarious. There are instances without number where acts, necessary for the general good, and which rise out of the powers given to Congress, must interfere with the internal police of the States; and there are as many instances in which the particular States by arrangements of internal police, can effectually, though indirectly, counteract the arrangements of Congress. You have already had examples of this, for which I refer you to your own memory.

The Confederation gives the States, individually, too much influence in the affairs of the army. They should have nothing to do with it. The entire formation and disposal of our military forces ought to belong to Congress. It is an essential cement of the union; and it ought to be the policy of Congress to destroy all ideas of State attachments in the army, and make it look up wholly to them. For this purpose all appointments, promotions, and provisions, whatsoever, ought to be made by them. It may be apprehended that this may be dangerous to liberty. But nothing appears more evident to me than that we run much greater risk of having a weak and disunited federal government, than one which will be able to usurp upon the rights of the people.

Alexander Hamilton, Works. I. 205.

JEFFERSON (1821)

Our first essay, in America, to establish a federative government had fallen, on trial, very short of its object. During the war of Independence, while the pressure of an external enemy hooped us together, and their enterprises kept us necessarily 
on the alert, the spirit of the people, excited by danger, was a supplement to the Confederation, and urged them to zealous exertions, whether claimed by that instrument or not; but, when peace and safety were restored, and every man became engaged in useful and profitable occupation, less attention was paid to the calls of Congress. 'The fundamental defect of the Confederation was, that Congress was not authorized to act immediately on the people, and by its own ofticers. 'Their power was only requisitory, and these requisitions were addressed to the several Legislatures, to be by them carried into exeention, without other coercion than the moral principle of duty. This allowed, in fact, a negative to every Legislature, on every measure proposed by Congress; a negative so frequently exercised in practice, as to benumb the action of the Federal government, and to render it inefficient in its general objects, and more especially in pecuniary and foreign concerns. The want, too, of a separation of the Legislative, Executive, and Judiciary functions, worked disadvantageously in practice. Yet this state of things afforded a happy augury of the future march of our Confederacy, when it was seen that the good sense and good dispositions of the people, as soon as they perceived the incompetence of their first compact, instead of leaving its correction to insurrection and civil war, agreed, with one voice, to elect deputies to a general Convention, who should peaceably meet and agree on such a Constitution as "would ensure peace, justice, liberty, the common defence and general welfare."

Thomas Jefferson, Works. I. 78.

\section{CRITICAL COMMENT}

STORY (1833)

The last defect which seems worthy of enumeration, is, that the confederation never had a ratification of the People. Upon this objection, it will be suffieient to quote a single passage from the Federalist, as it affords a very striking commentary upon some extraordinary doctrines recently promulgated. "Resting on no better foundation than the consent of the state legislatures, it [the confederation] has been exposed to frequent and intricate questions concerning the validity of its powers; 
and has, in some instances, given birth to the enormous doctrine of a right of legislative repeal. Owing its ratification to a law of a state, it has been contended, that the same authority might repeal the law, by which it was ratified. However gross a heresy it may be to maintain, that a party to a compact has a right to revoke that compact, the doctrine itself has had respectable advocates. The possibility of a question of this nature proves the necessity of laying the foundations of our national government deeper, than in the mere sanction of delegated authority. The fabric of American empire ought to rest on the solid basis of the consent of the people. The streams of national power ought to flow immediately from that pure, original fountain of all legitimate authority."

Joseph Story, Commentaries on the Constitution of the United States. 103.

\section{J. A. JAMESON (1866)}

The Constitution of the Confederation, therefore, when ratified in the manner explained, was an entirely legitimate one; that is, it was proposed to the constituent bodies to be governed by it, and by the latter ratified and confirmed by an express rote ; but it was legitimate only for what it purported to be - a league between States, and not a national Constitution, in the proper sense of the word. 'Tested by the principles that should preside over the formation of a Constitution, it was, in its inception, not legitimate, for it wanted the sanction of the people, who, as distinct from their governments, are alone the constituents, or have power to ratify the Constitution. . . . Such was the first essay of our fathers in framing a government for United America. The system resulting from it, the joint product of inexperience and State jealousy, eame soon to merit the general contempt from its weakness. . . .

There is scarcely a function of a good government in which it would not have proved itself altogether wanting.

Jons A. Jameson, Treatise on Constitutional Conventions. 147-148.

MULFORD (1870)

The Declaration of Independence was the act of the whole people; it calls the Americans one people, and its salutation is 
to them as fellow citizens. There is in it the assumption of no separate rights, and the record of no separate wrongs. The Declaration in its conception transcends the spirit of any of these separate communities, and was beyond their separate grasp. It was by the whole people that the war was carried on, and victory was won, and peace was established for the people. There was in these events beyond argument the evidence of the divine guidance of the people.

. . The subsequent circumstance of the deepest significance is that the people sought to realize its purpose under the articles of a confederation. It was the assumption of a confederate principle, although in the nature of things it induced inevitable contradictions; thus, while the separate States are represented as sovereign, they are not so in reality, but the attributes of political sovereignty are withdrawn from them; then also the articles are called the Articles of Confederation, but they are also described as articles of perpetual union; the acts which were then performed under the articles were incongruous with a confederate conception, and thus the Congress of the people proceeded to enact laws as if invested with positive powers, and thus the great seal of the United States with its legend of unity was adopted; and treaties were confirmed by the Congress, in which the nation was bound by obligations to other nations, and the whole people was held by them; under these articles also, - so far was the condition removed from an actual sovereignty in the separate communities, - in the highest issues, and those which involved the very being of the people, the ultimate determination was with nine of the thirteen communities, and this formal political action was imperative over the whole. But the fact of the most enduring import is that these articles of confederation had no continuance; but after a very brief period of confusion and disaster they fell away, partly through their inherent weakness, and partly because they did not correspond to the real constitution, and could not embody the real spirit and purpose of the people.

Elisha Mulford, The Nation. 331-333. 
VON HOLST (1875)

On the fourth of July, the Declaration of Independence was adopted, the import of which, as has been already remarked, was in accordance with the resolution of the 10th of June. Eight days later, on the 12 th of July, the last-named committee submitted to congress the draft of the articles of eonfederation. On the 15th of November, 1777, the artieles, after they had undergone several amendinents. were accepted by congress, and it was resolved to recommend them to the legislatures of the states for adoption.

... The articles of confederation start out with the assumption that from the date of the Declaration of Independence each state became de facto and de jure an independent state, competent henceforth to form a confederacy with the other states whenever it saw fit, and to the extent that it saw fit. How this assumption was to be reconciled with the fact that the congress had been in existence for years, and had actually excrcised sovereign power from the first, while the individual states had assumed no sovereign attitude, theoretically or practically, toward England or other foreign countries, does not appear.

-. The changes effected by the articles of confederation were rather of a negative than of a positive nature. They did not give the state which was just coming into being a definite form, but they began the work of its dissolution. The essential prerogatives which necessarily belong to a political community in its relations with other powers, they confided by law to confederate anthorities, from whom, in practice, they withheld all power. On the other hand, they confided all actual power to the component parts of the whole, but did not and could not for themselves, still less for the whole, give them the right to assume the responsibilities or enforce the rights which regulate the relations of sovereign states.

The practical result of this was that the United States tended more and more to split up into thirteen independent republics, and in the same measure, they virtually ceased to be a member of the family of nations bound together by the jus gentium. The European powers rightly saw in the Union only a sladow 
without substance, and besides they had no occasion and no desire to have any relations with the individual states as sovereign bodies.

Dr. H. Vox Houst, Constitutional History of the United States. I. 20-24.

HART (1891)

The Continental Congress took upon itself the management of the military, finaucial, and foreign affairs of the thirteen colonies which united in the movement. A year later it took the logical step of proclaiming to the world the fact which had for months been existent - the independence of the colonies from Great Britain. In all these acts the colonies and the people acquiesced. An informal but effective confederation was thus formed.

During the five years following acquiescence was not always obtained, and the Congress went through the humiliations of a body unknown to constitutional law, and inadequately supplied with strength. But practically it was a true, though temporary government: it made treaties, issued legal tender notes, borrowed money, commissioned generals, directed campaigns. The practical and the legal inception of the Union is to be found in the acceptance by the people of the work of a body without a legal warrant, but neverthcless actually the government of all the thirteen States.

.. The government thus established was a Staatenbund: to us it seems weak; when founded it was bound by the strongest federal ties then known. The Congress was a weak organ with all the functions of government; but it was in every way superior to the Swiss Diet, and, except in financial powers, to the States General of the Netherlands. The powers of government were few and feebly sustained; but they were larger than those of the Holy Roman Empire. The nation found a Congress in existence, and as a Congress it was continued. The powers committed to it were, in the main, such as had previously been exercised by the Continental Congress, and such as the colonies had been accustomed to see carried on for them by the British Home Government. Even in its defects, the Confederation closely resembled its predecessor, the Continental Congress; it was a clumsy contrivance, so far as ex- 
ecutive and judicial matters were concerned; and it had no direct relations with individuals.

Albert Bushell Hart, Federal Government, 54-56.

\section{HENRY JONES FORD (1898)}

The period of the Confederation was one in which the functions of general government were in abeyance. . . People eared nothing about the principles on which the government of the Confederation was based, because they cared nothing for that government. The Congress of the Confederation, although it remained in existence fourteen years, never took root in the affection or respect of the people. Its sittings were private, and its proceedings made no appeal to public opinion.

Henry Jones Ford, Rise and Growth of American Politics. 36, 37.

\section{STEVENS (1894)}

On the very day that saw the Declaration put forth, steps were taken which led to the adoption, in the following year, of "Articles of Confederation and Perpetual Union," binding all the States in a "firm league of friendship with each other." This earliest attempt at the construction of a national government established what, as the sequel proved, was neither national nor a government. . . . Not to trace its disastrous history in cletail, enough to say, that its ineompetency for all purposes for which it was established, brought about, after ten years of failure, its utter breakdown.

C. E. Stevens, Sources of the Constitution of the United States. 40.

FISKE (1894)

John Dickinson is supposed to have been the principal anthor of the articles of confederation : but as the work of the committee was done in secret and has never been reported, the point cannot be determinerl. . . According to the language of the articles, the states entered into a firm league of friendship with each other; and in order to sccure and perpetuate such friendship, the freemen of each state were entitled to all the privileges and immunities of freemen in all the other states. Mutual extradition of criminals was established, and in each state full faith and credit was to he given to the records, acts, 
and judicial proceedings of every other state. This universal intercitizenship was what gave reality to the nascent and feeble union. In all common business relations of life, the man of New Hampshire could deal with the man of Georgia on an equal footing before the law. But this was almost the only effectively cohesive provision in the whole instrument.

Jorn Fiske, Critical Period of American History. 94.

\section{FISHER (1897)}

It was unquestionably a very weak government, - a mere league with so few of the attributes of federalism, and those few so restricted, that it was not a federal or a national government in any true sense of the word. The fashion has prevailed for a long time of attacking it in very severe terms, and even of questioning the patriotism of the men who framed it. But we must remember that it was simply a link in a long chain of evolution which had been progressing for over a bundred years, and continued, as we shall see, in the same steady course. It was a great advance on all the plans that had preceded it, and, for purposes of development that was all that was required.

The criticisms on its lack of federal power began almost as soon as it appeared. When signed by the members of Congress and sent to the States for ratification in 1778 , most of those States had finished their new constitutions. on which they had been engaged for several years. Constitution-making was the order of the day; everybody was prepared for discussion, and no previous plan of union received such serious and trained consideration.

Though the prevailing sentiment seems to have been that not enough power was given, there were many who saw in the Articles of Confederation a menace to the sovereignty of the States. But even this state rights party, while they wished greater safeguards for local liberty, wanted at the same time more power and efficiency in the general government.

Sidney George Fisher, The Evolution of the Constitution of the United States. $249,250$. 


\section{Chapter XVI \\ THE NORTHWEST ORDINANCE \\ (1787)}

\section{SUGGESTIONS}

THE Ordinance of 1787 contained the essence of all later constitutional government for national domain. It was by far the most important piece of general legislation of the epoch preceding the Constitutional Convention.

The document was the conception of Dr. Manasseh Cutler of Massachusetts; it was reported to Congress by Nathan Dane, as chairman of a committee to whom the subject had been referred, and it was passed with almost no alteration. The question of the competence of Congress to pass this frame of govermment has given occasion to much argument; but it is of little moment, as the first Congress under the Constitution re-enacted it.

The picturesque side of history comes out in the study of this document. With the exception of the Puritan emigration, perhaps no one episode in the growth of America sets forth more distinctly the conditions, hopes, and aspirations of the people than this movement on the part of a body of New Englanders, to open up the Northwest Territory. The fact that the territory itself was ceded to the mothergovernment by the different child-states gave a personal interest to the frame of laws whereby this territory was to be governed. In the perusal of this document it is well to trace the special quality of civil rights, Habeas Corpus, trial by jury, bail, fines and punishments, treatment of Indians, education, freedom of religion, and emancipation of the negro. These enlightened provisions of this Ordinance should be examined carefully as in a measure foreshadowing the doctrines of the last three amendments of the Constitution.

The Northwest Ordinance is in reality a colonial charter, and the foundation of the governinent of our later colonies - usually called territories. Hence this document has an important relation to the problems of colonial government which of late press upon the United States.

For Outlines and Material, see Appendix B. 


\section{DOCUMENT}

\section{The Ordinance of ${ }^{1787}$}

Journals of Congress, XII. 85-93.
AN ORDINANCE FOR THE GOVERNMEN'T OF THE TERRITORY OF THE UNITED STATES, Nortil-West OF the RIVER OHIO

BE IT ORDAINED by the United States in Congress assembled, 'That the said territory, for the purposes of temporary government, be one district; subject, however, to be divided into two districts, as future circumstances may in the opinion of Congress, make it expedient.

Be it ordained by the authority aforesaid, That the estates, both of resident and non-resident proprietors in the said territory, dying intestate, shall descend to, and be distributed among their children, and the descendants of a deceased child in equal parts; the descendants of a deceased child or grandchild, to take the share of their deceased parent in equal parts among them: And where there shall be no children or descendants, then in equal parts to the next of kin, in equal degree; and among collaterals, the children of a deceased brother or sister of the intestate, shall have in equal parts among them, their deceased parents' share; and there shall in no case be a distinction between kindred of the whole and half blood; saving in all cases to the widow of the intestate, her third part of the real estate for life, and one third part of the personal estate; and this law relative to descents and dower, shall remain in full force until altered by the legislature of the district. - And until the governor and judges shall adopt laws as herein after mentioned, estates in the said territory may be devised or bequeathed by wills in writing, signed and sealed by him or her, in whom the estate may be (being of full age) and attested by three wit. 
nesses; - and real estates may be conveyed by lease and release, or bargain and sale, signed, sealed, and delivered by the person being of full age, in whom the estate may be, and attested by two witnesses, provided such wills be duly proved, and such conveyances be acknowledged, or the execution thereof duly proved, and be recorded within one year after proper magistrates, courts, and registers shall be appointed for that purpose; and personal property may be transferred by delivery; saving, however, to the French and Canadian inhabitunts, and other settlers of the Kaskaskies, Saint Vincent's, and the neighbouring villages, who have heretofore professed themselves citizens of Virginia, their laws and customs now in force among them, relative to the descent and conveyance of property.

Be it ordained by the authority aforesaid, That there shall be appointed from time to time, by Congress, a governor, whose commission shall continue in force for the term of three years, unless sooner revoked by Congress, he shall reside in the district, and have a freehold estate therein, in one thousand acres of land, while in the exercise of his oftice.

There shall be appointed from time to time, by Congress, a secretary, whose commission shall continue in force for four years, unless sooner revoked; he shall reside in the district, and have a freehold estate therein, in five hundred acres of land, while in the exercise of his office; it shall be his duty to keep and preserve the acts and laws passed by the legislature, and the public records of the district, and the proceedings of the governor in his executive department; and transmit authentic copies of such acts and proceedings, every six months, to the secretary of Congress: There shall also be appointed a court to consist of three judges, any two of whom to form a court, who shall have a common law jurisdiction, and reside in the district, and have each 
therein a freehold estate in five hundred acres of land, while in the exercise of their offices; and their commissions shall continue in force during good behaviour.

The governor and judges, or a majority of them, shall adopt and publish in the district, such laws of the original states, criminal and civil, as may be necessary, and best suited to the circumstances of the district, and report them to Congress, from time to time; which laws shall be in force in the district until the organization of the general assembly therein, unless disapproved of by Congress; but afterwards the legislature shall have authority to alter them as they shall think fit.

The governor for the time being, shall be commander in chief of the militia, appoint and commission all officers in the same, below the rank of general officers; all general officers shall be appointed and commissioned by Congress.

Previous to the organization of the general assembly, the governor shall appoint such magistrates and other civil officers, in each county or township, as he shall find necessary for the preservation of the peace and good order in the same: After the general assembly shall be organized, the powers and duties of magistrates and other civil officers shall be regulated and defined by the said assembly; but all magistrates and other civil officers, not herein otherwise directed, shall, during the continuance of this temporary government, be appointed by the gorernor.

This gave For the prevention of crimes and injuries, the rise to colli- laws to be adopted or made shall have force in all sions between the government and the people. parts of the district, and for the execution of process, criminal and civil, the governor shall make proper divisions thereof - and he shall proceed from time to time, as circumstances may require, to lay out the parts of the district in which the Indian titles shall have been extinguished, into 
counties and townships, subject, however, to such alterations as may thereafter be made by the legislature.

So soon as there shall be five thousand free male Such a govinhabitants, of full age, in the district, upon giving ernment was proof thereof to the governor, they shall receive later. authority, with time and place, to elect representatives from their counties or townships, to represent them in the general assembly; provided that for every five hundred free male inhabitants, there shall be one representative, and so on progressively with the number of free male inhabitants sliall the right of representation increase, until the number of representatives shall amount to twenty-five; after which the number and proportion of representatives shall be regulated by the legislature: provided that no person be eligible or qualified to act as a representative, unless he shall have been a citizen of one of the United States three years, and be a resident in the district, or unless he shall have resided in the district three years; and in either case shall likewise hold in his own right, in fee simple, two hundred acres of land within the same: provided also, that a freehold in fifty acres of land in the district, having been a citizen of one of the states, and being resident in the district, or the like freehold and two years residence in the district shall be necessary to qualify a man as an elector of a representative.

The representatives thus elected, shall serve for the term of two years; and in case of the death of a representative, or removal from office, the govcrnor shall issue a writ to the county or township, for which he was a member, to elect another in his stead, to serve for the residue of the term.

'The general assembly, or legislature, shall consist The appointof the governor, legislative council, and a house of ive council representatives. The legislative council shall con- was an instisist of five members, to continue in office five years, disliked. unless sooner removed by Congress; any three of 
whom to be a quorum: and the members of the council shall be nominated and appointed in the following manner, to wit: As soon as representatives shall be elected, the governor shall appoint a time and place for them to meet together, and, when met, they shall nominate ten persons, residents in the district, and each possessed of a freehold in five bundred acres of land, and return their names to Congress ; five of whom Congress shall appoint and commission to serve as aforesaid; and whenever a vacancy shall happen in the council, by death or removal from office, the house of representatives shall nominate two persons, qualified as aforesaid, for each vacancy, and return their names to Congress; one of whom Congress shall appoint and commission for the residue of the term. And every five years, four months at least before the expiration of the time of service of the members of council, the said house shall nominate ten persons, qualified as aforesaid, and return their names to Congress; five of whom Congress shall appoint and commission to serve as members of the council five years, unless sooner removed. And the governor, legislative council, and house of representatives, shall have authority to make laws, in all cases. for the good government of the district, not repugnant to the principles and articles in this ordinance established and declared. And all bills having passed by a majority in the house, and by a majority in the couneil, shall be referred to the governor for his assent; but no bill or legislative act whatever, shall be of any force without his assent. The governor shall have power to convene, prorogue and dissolve the general assembly, when in his opinion it shall be expedient.

This has been the practice for territories ever since.

The governor, judges, legislative council, secretary, and such other officers as Congress shall appoint in the district, shall take an oath or affirmation of fidelity, and of office; the governor before 
the president of Congress, and all other officers before the governor. As soon as a legislature shall be formed in the district, the council and house assembled, in one room, shall have authority, by joint ballot, to elect a delegate to Congress, who shall have a seat in Congress, with a right of debating, but not of voting during this temporary government.

And for extending the fundamental principles of civil and religious liberty, which form the basis whereon these republics, their laws and constitutions are erected ; to fix and establish those principles as the basis of all laws, constitutions, and governments, which forever hereafter shall be formed in the said territory : to provide also for the establishment of states, and permanent government therein, and for their admission to a share in the fecleral councils on an equal footing with the original states, at as early periods as may be consistent with the general interess: :

It is hereby ordained and declared, by the au-This is an thority aforesaid, "'hat the following articles shall acknowledgbe considered as articles of compact between the principle of original states, and the people and states in the said limited deterritory, and forever remain unalterable, unless by mocracy. common consent, to wit:

Article the first. No person, demeaning himself Va. Bill of in a peaceable and orderly manner, shall ever be Freedom of molested on account of his mode of worship or worship first religious sentiments, in the said territory. federal

Article the second. The inhabitants of the said government. territory, shall always be entitled to the benefits of See Magna the writ of habeas corpus, and of the trial by jury ; 40 . of a proportionate representation of the people in This article the legislature, and of judicial proceedings accord- was copied ing to the course of the common law. All persons Constitution shall be bailable, unless for capital offences, where of the United the proof shall be evident, or the presumption great. States. It All fines shall be moderate; and no cruel or unusual growth of 
the trade dis- punishments shall be inflicted. No man shall be

turbance throughout the country.

The first recognition after the Revolution that public education was the duty of government.

There seems no doubt that the Northwest Territory was considered to be an integral part of the United States, subject to the limitations, and enjoying the privileges of the Articles of Confederation. deprived of his liberty or property, but by the judgment of his peers, or the law of the land, and should the public exigencies make it necessary, for the common preservation, to take any person's property, or to demand his particular services, full compensation shall be made for the same. And in the just preservation of rights and property, it is understood and declared, that no law ought ever to be made, or have force in the said territory, that shall in any manner whatever interfere with, or affect private coutracts or engagements, bona fide, and without fraud previously formed.

Article the third. Religion, morality and knowledge, being necessary to good government and the happiness of mankind, schools and the means of education shall forever be encouraged. The utmost good faith shall always be observed towards the Indians; their lands and property shall never be taken from them withont their consent; and in their property, rights and liberty, they never shall be inraded or disturbed, unless in just and lawful wars authorised by Congress; but laws founded in justice and humanity shall from time to time be made, for preventing wrongs being done to them, and for preserving peace and friendship with them.

Article the fourth. The said territory, and the states which may be formed therein, shall forever remain a part of this confederacy of the United States of America, subject to the articles of confederation, and to such alterations therein, as shall be constitutionally made; and to all the acts and ordinances of the United States in Congress assembled, conformable thereto. The inhabitants and settlers in the said territory, shall be subject to pay a part of the federal debts, contracted or to be contracted, and a proportional part of the expences of government, to be apportioned on them by Con- 
gress, according to the same common rule and measure, by which apportionments thereof shall be made on the other states; and the taxes for paying their proportion, shall be laid and levied by the authority and direction of the legislatures of the district or districts or new states, as in the original states, within the time agreed upon by the United States in Congress assembled. The legislatures of those districts or new states, shall never interfere with the primary disposal of the soil by the United States in Congress assembled, nor with any regulations Congress may find necessary for securing the title in such soil to the bona fide purchasers. No tax shall be imposed on lands the property of the United States; and in no case shall non-resident proprietors be taxed higher than residents. The navigable waters leading into the Missisippi and St. Lawrence, and the carrying places between the same, shall be common highways, and forever free, as well to the inhabitants of the said territory, as to the citizens of the United States, and those of any other states that may be admitted into the confederacy, without any tax, impost, or duty therefor. Article the fifth. There shall be formed in the said territory, not less than three, nor more than five states; and the boundaries of the states, as soon as Virginia shall alter her act of cession, and consent to the same, shall become fixed and established as follows, to wit: The western state in the said territory, shall be bounded by the Missisippi, the Ohio and Wabash rivers; a direct line drawn from the Wabash and Post Vincents due north to the territorial line between the United States and Canada; and by the said territorial line to the lake of the Woods and Missisippi. The middle state shall be bounded by the said direct line, the Wabash from Post Vincents to the Ohio; by the Ohio, by a direct line drawn due north from the month of the Great Miami, to the said territorial line, and by the 
said territorial line. The eastern state shall be bounded by the last mentioned direct line, the Ohio, Pennsylvania, and the said territorial line: provided however, and it is further understood and declared, that the boundaries of these three states, shall be subject so far to be altered, that if Congress shall hereafter find it expedient, they shall have authority to form one or two states in that part of the said territory which lies north of an east and west line drawn through the southerly bend or extreme of The Colonial lake Michigan. And whenever any of the said status of the states, shall have sixty thousand free inhabitants Territory Territory was intended gates, into the Congress of the United States, on an to be temporary. equal footing with the original states, in all respects whatever; and shall be at liberty to form a permanent constitution and state government: provided the constitution and government so to be formed, shall be republican, and in conformity to the principles contained in these articles; and so far as it can be consistent with the general interest of the confederacy, such admission shall be allowed at an earlier period, and when there may be a less number of free inhabitants in the state than sixty thousand.

This article Article the sixth. There shall be neither slavery did not com- nor involuntary servitude in the said territory, pletely dedi- otherwise than in the punishment of crimes, whereof
cate the Northwest to th freedom, since slaves then in the territory could be held so long as they lived, but it was practically an anti-slavery clause.

the party shall have been duly convicted: provided always, that any person escaping into the same, from whom labour or service is lawfully claimed in any one of the original states, such fugitive may be lawfully reclaimed, and conveyed to the person claiming his or her labour or service as aforesaid. $\mathrm{Be}$ it ordained by the authority aforesaid, That the resolutions of the 23d of April, 1784, relative to the subject of this ordinance, be, and the same are hereby repealed and declared null and void. 


\section{CONTEMPORARY EXPOSITION}

DANE (1787)

New York, July 16, 1787.

Dear SrR : - I am obliged to you for yours of the 11th inst. With pleasure I communicate to you what we are doing in Congress, not so much from a consciousness that what we do is well done, as from a desire that you may be acquainted with our proceedings. We have been much engaged in business for ten or twelve days past, for a part of which we have had 8 states. There appears to be a disposition to do business; and the arrival of R. H. Lee is of considerable importance. I think his character serves at least in some degree, to check the effects of the feeble habits and too [tardy?] modes of thinking in some of his countrymen. We have been employed about several objects - the principal ones of which have been the Government inclosed, and the Ohio Purchase. The former you will see is completed, and the latter will be probably completed to-morrow. We tried one day to patch up M. S. P. systems of W. Govern't. Started new ideas, and committed the whole to Carrington, Dane, R. H. Lee, Smith, and Kean. We met several times, and at last agreed on some principles, at least Lee, Smith and myself. We found ourselves rather pressed; the Ohio Company appeared to purebase a large tract of the Federal lands - about 6 or 7 millions of acres; and we wanted to abolish the old system, and get a better one for the Government of the country - and we finally found it necessary to adopt the best system we conld get. All agreed, finally, to the inclosed, except A. Yates. He appeared in this case, as in most others, not to understand the subject at all. I think the number of free inhabitants, 60,000 , which are requisite for the admission of a new State into the Confederacy, is too small; but, having divided the whole territory into three States, this number appeared to me to be less important. Each State, in the common course of things, must become important soon after it shall have that number of inhabitants. The Eastern State of the three will probably be the first, and more important than the rest, and will, no doubt, be settled chiefly by Eastern people; and there is, I think, full 
an equal chance of its adopting Eastern politics. When I drew the Ordinance, which passed (a few words excepted) as I originally formed it, I had no idea the States would agree to the Sixth art. prohibiting slavery, as only Massa. of the Eastern States was present, and therefore omitted it in the draft; but, finding the House favourably disposed on this subject, after we had completed the other parts, I moved the art., which was agreed to without opposition. We are in a fair way to fix the terms of our Ohio sale, etc.; we have been upon it steadily three days. The magnitude of the purchase makes us very cautious about the terms of it, and the security necessary to insure the performance of them.

We have directed the Board to inquire into and report on Hothers affairs, etc.

Massa. Legisa. was prorogued the 7 th inst., having continued the Tender Act, as it is called, to Jan. 1, 1788, and having passed no other Act of importance, except what, I presume, you have seen, respecting the raising of troops, and the powers of the Governor to pursue the rebels, etc.

You ask me how I like my new colleagues. Sedgwick, you know, we all esteem, but I fear he will not make his attendance an object. Thatcher, I am quite unacquainted with. I do not know whether Mr. Otis, at his period of life, and under his misfortune, will enter with vigour into Federal politics. I wish his accounts with the Union had been settled, etc.

Nothing occurs worth particular notice.

Hon. Rufus King, Esq.

Your affecta. friend,

N. Dane.

P. S. - States present: Massa., N. Y., N. J., Delaware, Virga., N. Cara., So. Carolina, and Georgia. Brother Holton is rather an invalid, is not well able to take an active part in business, but I think supports pretty good Fastern politics.

Nathan Dane, in Cutrers, Life of Manasseh Cutler. I. 371-373.

\section{CRITICAL COMMENT}

WEBSTER (1830)

At the foundation of the constitution of these new Northwestern States lies the celebrated Ordinance of 1787 . We 
are accustomed, Sir, to praise the lawgivers of antiquity; we help to perpetuate the fame of Solon and Lyeurgus; but I doubt whether one single law of any lawgiver, ancient or modern, has produced effects of more distinet, marked, and lasting charaeter than the Ordinance of 1787 . That instrument was drawn by Nathan Dane, then and now a eitizen of Massachusetts. It was adopted, as I think I have understood, without the slightest alteration; and certainly it has happened to few men to be the anthors of a political measure of more large and enduring consequence. It fixed for ever the eharacter of the population in the vast regions northwest of the Ohio, by excluding from them involuntary servitude. It impressed on the soil itself, while it was yet a wilderness, an ineapacity to sustain any other than freemen. It laid the interdict against personal servitude, in original compact, not only deeper than all local law, but deeper, also, than all constitutions. Under the cirenmstances then existing, I look upon this original and seasonable provision as a real good attained.

Daniel Webster, Works. III. 263, 264.

\section{CHASE (1833)}

By that [ordinance] of 1787 , provision was made for suecessive forms of territorial government, adapted to suceessive steps of adrancement in the settlement of the western country. It eomprehended an intelligible system of law on the descent and conveyanee of real property, and the transfer of personal goods. It also contained five articles of compact between the original states, and the people and states of the territory, establishing eertain great fundamental principles of governmental duty and private right, as the basis of all future constitutions and legislation, unalterable and indestructible except by that final and common ruin, which as it has overtaken all former systems of human polity, may yet overwhelm our Ameriean union. Never, probably, in the history of the world, did a measure of legislation so accurately fulfil, and yet so mightily exceed the anticipations of the legislators. The ordinance has been well (lescribed, as liaving been a pillar of eloud by day, and of fire by night, in the settlement and government of the northwestern states. When the settlers went into the wilder- 
ness, they found the law already there. It was impressed upon the soil itself, while it yet bore up nothing but the forest. The purchaser of land became, by that act, a party to the compact, and bound by its perpetual covenants, so far as its conditions did not conflict with the terms of the cessions of the states.

Salmon P. Chase, Sketch of the History of Ohio. 8-9.

BANCROFT (1834)

Before the Federal Convention had referred its resolutions to a committee of detail, an interlude in Congress was shapening the character and destiny of the United States of America. Sublime and humane and eventful in the history of mankind as was the result, it will take not many words to tell how it was brought about. For a time wisdom and peace and justice dwelt among men, and the great Ordinance, which could alone give continuance to the union, came in serenity and stillness. Every man that had a share in it seemed to be led by an invisible hand to do just what was wanted of him; all that was wrongfully undertaken fell to the ground to wither by the wayside; whatever was needed for the happy completion of the mighty work arrived opportunely, and just at the right moment moved into its place.

George Bancroft, History of the United States (final revision). VI. 277.

JACOB BURNET (1847)

The great principles of civil and religious liberty contained in this invaluable document, were guaranteed to the people of the Territory and their posterity forever, by the venerable Fathers of the Revolution, which entitled them to endless gratitude.

J tory. 304.

HOAR (1887)

The Ordinance of 1787 belongs with the Declaration of Independence and the Constitution. It is one of the three title deeds of American constitutional liberty. As the American youth for uncounted centuries shall visit the capital of his country - strongest, richest, freest, happiest of the nations of 
the earth - from the stormy coast of New England, from the luxuriant regions of the Gulf, from the lakes, from the piairie and the plain, from the Golden Gate, from far Alaska - he will admire the evidences of its grandeur and the monuments of its historic glory. He will find there rich libraries and vast museums and great cabinets, which show the product of that matchless inventive genius of America, which has multiplied a thousand fold the wealth and comfort of human life. He will see the simple and modest portal through which the great line of the Republic's chief magistrates have passed at the call of their country to assume an honour surpassing that of emperors and kings, and through which they have returned, in obedience to her laws, to take their place again as equals in the ranks of their fellow-citizens. He will stand by the matchless obelisk which, loftiest of human structures, is itself but the imperfect type of the loftiest of human characters. He will gaze upon the marble splendours of the capitol, in whose chambers are enacted the statutes under which the people of a continent dwell together in peace, and the judgments are rendered which keep the forces of state and nation alike within their appointed bounds. He will look upon the record of great wars and the statues of great commanders. But if he knew his country's history, and considered wisely the sources of her glory, there is nothing in all these which will so stir his heart as two faded and time-soiled papers, whose characters were traced by the hand of the fathers a hundred years ago. They are the original records of the acts which devoted this nation forever to equality, to education, to religion and to liberty. One is the Declaration of Independence, the other the Ordinance of 1787.

George F. Honr, Oration at Centennial at Marietta.

\section{HINSDALE (1888)}

We have seen that four different ordinances had been previously reported to Congress, and that one had already been enacted. The fifth and great Ordinance, as Mr. Bancroft says, embodied the best parts of all its predecessors. But it embodied more; and all the evidence points to the conclusion that much of the new material was contained in the papers that Dr. Cutler handed to the committee, July 10th, after he 
had studied the ordinance then pending. Whoever may have brought thein forward, the imperishable principles of polity woven into the Ordinance of 1787 were the ripe fruit of many centuries of Anglo-Saxon civilization; but the best places to search for them are the bills of rights of the Revolutionary constitutions. . . . No act of American legislation has called out more eloquent applause than the Ordinance of 1787. Statesmen, historians, and jurists have vied with one another in celebrating its praises. In one respect it has a proud pre-eminence over all other acts of legislation on the American statute-books. It alone is known by the date of its enactment, and not by its subject-matter. It was more than a law or statute. It was a constitution for the Territory Northwest of the River Ohio. More than this, it was a model for later legislation relating to the national territories; and some of its provisions, particularly the prohibition of slavery, stand among the greatest precedents of our history.

Burke A. Hinsdale, The Old Northwest. ${ }^{1}$ 273, 276.

\section{CUTLERS (1888)}

Up to the time of Dr. Cutler's arrival in New York, the labors of Congress had brought forth abstractions and skeletons, mere outlines. It is not improbable that the presentation of a scheme of settlement, such as had " never been attempted in America," aroused the zeal and stimulated the efforts of Congress in a more practical direction, and led to the adoption of acceptable lines of policy in organizing the "new state" that had been so long the dream of an army by whose valor and sacrifices the territory had been acquired. That the organic law should have been new-modeled, and made acceptable to the men who were ready to occupy and cultivate that distant territory, is not surprising.

It may be claimed for the Ordinance itself, that it is the only instance in human history, (with a single exception) where the laws and constitutions have been prepared beforehand, pre-arranged, and projected into a territory prior to its occupation by its future inhabitants. The Divine economy did so arrange, pre-ordain, and publish to His chosen people the law,

1 Copyright, 1S39, by Silver, Burdett \& Co. 
ordinance, and polity that was to govern them after they had entered their promised land; but, throughout the many changes, migrations, and couquests under which the human race has spread itself over and occupied the earth, either the will of the conqueror after conquest and occupation, or the growth of goverumental principles subsequently, has been the origin of political and civil institutions. Here, however, is an attempt to prepare beforehand forms of government, laws, and principles upon bases that were intended to remain forever unalterable. We now have a century to attest their intrinsic value. Not the least valuable part of this wise forecast and preparation was that provision reaching down to the virgin soil that gave absolute ownership of it in convenient quantities and on terms that secured to each person an opportunity to acquire a homestead of his own, with provision for those civil divisions, townships, where the "essence of ownership," control, could be exerted politically in all the important social and civil affairs of life.

Upon this foundation, guarantees of human rights, in their broadest application, with equality before the law, were introduced into the governmental structure. In addition to these elements of future stability, the educational and moral forces are distinctly recognized and incorporated into the foundations. Freedom of worship, without governmeutal control, direction, or patronage; liberty, religion, morality, and knowledge - all stand side by side with the right of jury trial, habeas corpus, inviolability of private contracts, and all other usual and essential safeguards.

Cutlers, Life of Rev. Manasseh Cutler. 368, 369. 


\section{Chapter XVII \\ THE CONSTITUTION OF THE UNITED STATES (1787)}

\section{SUGGESTIONS}

The Constitutional Convention at Philadelphia met May 29, 1787. All the States were represented except Rhode Island. Washington, Franklin, Hamilton, and Madison were among the fifty-five members. The delegates sat with closed doors, keeping their proceedings secret. They decided that instead of revising the Articles of Confederation they would draw up an entirely new Constitution. George Washington presided over the convention, and Benjamin Franklin, Robert Morris, James Madison, Rufus King, Roger Sherman, Alexander Hamilton, John Dickinson, Charles C. Pinckney, J. Rutledge, and Gouverneur Morris, were among its distinguished members. Madison, Hamilton, Washington, and Franklin took the leading part in the great work of drafting the new Constitution, and after its adoption by the convention, Madison and Hamilton used their influence, with great effect, to urge its ratification by the states, especially New York. After a stormy session of nearly four months, during which the convention several times threatened to break up in hopeless dispute, the Constitution was at last adopted.

The fund of exposition and comment upon this document and its group of framers is of such extent that the few criticisms for which there is room might be many times multiplied. The Constitution, founded on compromises, made serviceable by its elasticity, and supplemented by an imperfect bill of rights, is a two-handed sword supporting the Federal government and yet ever ready to serve its purpose in defending the dignity of the State. The historical student who has made the previous documents a basis for the study of the Constitution may easily trace precedents for nearly all its strongest features. The supremacy of the Supreme Court, the power of the Executive, and the legislative authority of Congress unite in creating a well knit triune government such as was new in the history of mankind.

For Outlines and Material, see Appendix B. 


\section{DOCUMENT}

Constitution of the United States of America [1 $787-1789]$.

We the People of the United States, in Order to This text form a more perfect Union, establish Justice, in- is from sure domestic 'Tranquillity, provide for the com- History mon defence, promote the general Welfare, and Leaflets No. secure the Blessings of Liberty to ourselves and 8 , in which oul Posterity, do ordain and establish this CoN- from the stitution for the United States of America.

\section{ARTICLE. I.} original manuscript. Precedents for nearly all the import-

Section. 1. All legislative Powers herein granted ant features shall be vested in a Congress of the United States, of this docuRepresentatives.

SEction. 2. [\$1.] The House of Representatives documents, shall be composed of Members chosen every second and they may Year by the People of the several States, and the through the Electors in each State shall have the Qualifications colonial requisite for Electors of the most numerous Branch charters and of the State Legislature. [§ 2.] No Person shall be a Representative who this docustate constitutions into this docushall not have attained to the Age of twenty-five pare PreamYears, and been seven Years a Citizen of the United ble with Arts. States, and who shall not, when elected, be an In- and iii. habitant of that State in which he shall be chosen. Compare 1

[§3.] Representatives and direct Taxes shall be and 2 with [8 3.] Reprenticles of apportioned among the several States which may be Confederincluded within this Union, according to their respec- ation, v. tive Numbers, [which shall be determined by adding Superseded to the whole Number of free Persons, including by 14th the those bound to Service for a Term of Years, and ex- The contest cluding Indians not taxed, three fifths of all other over the Persons.] The actus of repP.ns.] 'The actual Enumeration shall be made resentation within three Years after the first Meeting of the ended in the Congress of the United States, and within every Compromise, subsequent Term of ten Years, in such Manner as which gave 
the states equal representation in the Senate and proportional representation in the House. The threefifths representation of slaves or the "Federal Ratio" was connected with the second great Compromise; to wit, that both representation and direct taxation should be according to Population. they shall by Law direct. The Number of Representatives shall not exceed one for every thirty Thousand, but each State shall have at Least one Representative; [and until such enumeration shall be made, the State of New Hampshire shall be entitled to chuse three, Massachusetts eight, RhodeIsland and Providence Plantations one, Connecticut five, New-York six, New Jersey four, Pennsylvania eight, Delaware one, Maryland six, Virginia ten: North Carolina five, South Carolina five, and Georgia three.]

[§4.] When vacancies happen in the Representation from any State, the Executive Authority thereof shall issue Writs of Election to fill such Vacancies.

[§5.] The House of Representatives shall chuse their Speaker and other Officers; and shall have the sole Power of Impeachment.

Section. 3. [\$1.] The Senate of the United States shall be composed of two Senators from each State chosen by the Legislature thereof, for six Years; and each Senator shall have one Vote.

[§ 2.] Immediately after they shall be assembled in Consequence of the first Election, they shall be divided as equally as may be into three Classes. The Seats of the Senators of the first Class shall be vacated at the Expiration of the second Year, of the second Class at the Expiration of the fourth Year, and of the third Class at the Expiration of the sixth Year, so that one third may be chosen every second Year; and if Vacancies happen by resignation, or otherwise, during the Recess of the Legislature of any State, the Executive thereof may make temporary Appointments until the next Meeting of the Legislature, which shall then fill such Vacancies.

[§3.] No Person shall be a Senator who shall not have attained to the Age of thirty Years, and been nine Years a Citizen of the United States, and who shall not, when elected, be an Inhabitant of that State for which he shall be chosen. 
[\$ 4.] The Vice President of the United States, Thisfunction shall be President of the Senate, but shall have no takendirectly Vote, unless they be equally divided. from New York's

[§5.] The Senate shall chuse their other Officers, constitution. and also a President pro tempore, in the Absence of the Vice President, or when he shall exercise the Office of President of the United States.

[§6.] 'The Senate shall have the sole Power to try all impeachments. When sitting for that Purpose, See Art. they shall be on Oath or Affirmation. When the ii. Sect.4. President of the United States is tried, the Chief Justice shall preside: And no Person shall be convicted withont the Concurrence of two thirds of the Members present.

[§ 7.] Judgment in Cases of Impeachment shall not extend further than to removal from Office, and disqualification to hold and enjoy any Office of honor, Trust or Profit under the United States; but the Party convicted shall nevertheless be liable and subject to Indictment, Trial, Judgment and Punishment, according to Law.

Section. 4. [ $\$ 1$ 1.] The Times, Places and Man- The only ner of holding Elections for Senators and Repre- case where sentatives, shall be prescribed in each State by the in terms set Legislatnre thereof; but the Congress may at any aside state time by Law make or alter such Regulations, except as to the Places of chusing Senators.

[§ 2.] The Congress shall assemble at least once in every Year, and such Meeting shall be on the first Monday in December, unless they shall by Law appoint a different Day.

Section. 5. $\left[\begin{array}{ll}\S & 1 .\end{array}\right]$ Each House shall be the This proviJudge of the Flections, Returns and Qualifications sion was of of its own Members, and a Majority of each shall origin; since constitute a Quorum to do Business; but a smaller 1868 the subNumber may adjourn from day to day, and may be ject has been authorized to compel the attendance of absent to the EngMembers, in such Manner, and under such Penalties as eaclı House may provirle. 
[§2.] Each House may determine the Rules of its Proceedings, punish its Members for Disorderly Behaviour, and, with the Concurrence of two thirds, expel a Member.

[§3.] Each House shall keep a Journal of its Proceedings, and from time to time publish the same, excepting such parts as may in their Judgment require Secrecy; and the Yeas and Nays of the Members of either House on any question shall, at the Desire of one fifth of those Present, be entered on the Journal.

[ $\$ 4$.$] Neither House, during the Session of$ Congress, shall, without the Consent of the other, adjourn for more than three days, nor to any other Place than that in which the two Houses shall be sitting.

Articles of Confederation, Art. v.

A privilege in its most ancient form. See Bill of Rights, Art. 9. Place.

Section. 6. [\$ 1.] The Senators and Representatives shall receive a Compensation for their Services, to be ascertained by Law, and paid out of the Treasury of the United States. They shall in all Cases, except Treason, Felony and Breach of the Peace, be privileged from Arrest during their Attendance at the Session of their respective Houses, and in going to and returning from the same; and for any Speech or Debate in either House, they shall not be questioned in auy other

[§ 2.] No Senator or Representative shall, during the Time for which he was elected, be appointed to any civil Office under the Authority of the United States, which shall have been created, or the Emoluments whereof shall have been encreased during such time; and no person holding any Office under the United States, shall be a Member of either House during his Continuance in Office.

Section. 7. [\$1.] All Bills for raising Revenue shall originate in the House of Representatives; but the Senate may propose or concur with Amendments as on other Bills. 
[§ 2.] Every Bill which shall have passed the House of Representatives and the Senate, shall, before it become a Law, be presented to the President of the United States; If he approve he shall sign it, but if not he shall return it, with his Objections to that House in which it shall have originated, who shall enter the Objections at large on their Journal, and proceed to reconsider it. If after such Reconsideration two thirds of that House shall agree to pass the Bill, it shall be sent, together with the Objections, to the other House, by which it shall likewise be reconsidered, and if approved by two-thirds of that House, it shall become a Law. But in all such Cases the Votes of Houses shall be determined by yeas and Nays, and the Names of the Persons voting for and against the Bill shall be entered on the Journal of each House respectively. If any Bill shall not be returned by the President within ten Days (Sundays excepted) after it shall have been presented to him, the same shall be a Law, in like Manner as if he had signed it, unless the Congress by their Adjournment prevent its Return, in which Case it shall not be a Law.

[§3.] Every Order, Resolution, or Vote to Directly which the Concurrence of the Senate and House of the MassaRepresentatives may be necessary (except on a chusetts question of Adjournment) shall be presented to the Constitution President of the United States; and before the See Instrusame shall take Effect, shall be approved by him, ment of Govor being disapproved by him, shall be repassed by xxiv. two thirds of the Senate and House of Representatives, according to the Rules and Limitations preseribed in the Case of a Bill.

Secrion. 8. The Congress shall have Power The power [ $\$ 1$.$] To lay and collect Taxes, Duties, Imposts to control all$ and Excises, to pay the Debts and provide for the most effectcominon Defence and general Welfare of the United ual control States; but all Duties, Imposts and Excises shall of the public be uniform throughout the United States; of the power 
of the executive. Compare (1) with Confed. Art.

ix.

This full list of congressional powers is but a modification or adaptation of the powers given to colonial legislatures and English Parliament dating back to Witenagemot. For example: note Magna Charta, Art. xxxv.
[§ 2.] To borrow Money on the credit of the United States;

[§3.] To regulate Commerce with foreign Nations, and among the several States, and with the Indian Tribes;

[§4.] To establish an uniform Rule of Naturalization, and uniform Laws on the subject of Bankruptcies throughout the United States;

[§5.] To coin Money, regulate the Value thereof, and of foreign Coin, and fix the Standard of Weights and Measures;

[§6.] To provide for the Punishment of counterfeiting the Securities and current Coin of the United States;

[§ 7.] To establish Post Offices and post Roads; [\$ 8.] To promote the Progress of Science and useful Arts, by securing for limited Times to Authors and Inventors the exclusive Right to their respective Writings and Discoveries;

[§9.] To constitute Tribunals inferior to the supreme Court ;

[§10.] To define and punish Piracies and Felonies committed on the high Seas, and Offences against the Law of Nations;

[§11.] To declare War, grant Letters of Marque and Reprisal, and make Rules concerning Captures on Land and Water;

[§ 12.] To raise and support Armies, but no Appropriation of Money to that Use shall be for a longer Term than two Years ;

[\$13.] To provide and maintain a Navy;

[§ 14.] To make Rules for the Government and Regulation of the land and naval Forces;

[§ 15.] To provide for calling forth the Militia to execute the Laws of the Union, suppress Insurrections and repel Invasions;

[§ 16.] To provide for organizing, arming, and disciplining, the Militia, and for governing such Part of them as may be employed in the Service of 
the United States, reserving to the States respectively, the Appointment of the Officers, and the Authority of training the Militia according to the discipline prescribed by Congress ;

[§ 17.] To exercise exclusive Legislation in all Cases whatsoever, over such District (not exceeding ten Miles square) as may, by Cession of particular States, and the Acceptance of Congress, become the Seat of the Grovernment of the United States, and to exercise like Authority over all Places purchased by the Consent of the Legislature of the State in which the same shall be, for the Erection of Forts, Magazines, Arsenals, dockYards, and other needful Buildings; - And

[ $\S 18$.$] To make all Laws which shall be neces- This$ sary and proper for carrying into Execution the clause later foregoing Powers, and all other Powers rested by disputed by this Constitution in the Government of the United and States, or in any Department or Officer thereof. Republicans.

Section. 9. $[\S 1$.$] [The Migration or Importa- Third com-$ tion of such Persons as any of the States now promise of existing Imexisting shall think proper to admit, shall not be portant beprohibited by the Congress prior to the Year one cause the thousand eight bundred and eight, but a Tax or Sote of thern duty may be imposed on such Importation, not States was exceeding ten dollars for each Person.]

[§2.] The Privilege of the Writ of Habeas See Magna Corpus shall not be suspended, unless when in Charta, Art. Cases of Rebellion or Invasion the public Safety xxxvi. may require it.

[§3.] No Bill of Attainder or ex post facto These $\begin{aligned} & \text { The } \\ & \text { clauses ex- }\end{aligned}$ Law shall be passed.

[§ 4.] No Capitation, or other direct, Tax shall tended by the be laid, unless in Proportion to the Census or first eight Enumeration herein before directed to be taken.

[§5.] No Tax or Duty shall be laid on Articles exported from any State.

[§6.] No Preference shall be given by any Regulation of Commcrce or Revenue to the Ports of 
The appropriation of supplies (1353) and auditing accounts (1407) are here combined.

one State over those of another: nor shall Vessels bound to, or from, one State, be obliged to enter, clear, or pay Duties in another.

[§ 7.] No Money shall be drawn from the Treasury, but in Consequence of Appropriations made by Law ; and a regular Statement and Account of the Receipts and Expenditures of all public Money shall be published from time to time.

[§8.] No Title of Nobility sluall be granted by the United States: And no Person holding any Office of Profit or 'Trust under them, shall, without the Consent of the Congress, accept of any present, Emolument, Office, or Title, of any kind whaterer, from any King, Prince, or foreign State.

Section. 10. [\$ 1.] No State shall enter into any Treaty, Alliance, or Confederation; grant Letters of Comp. with Marque and Reprisal; coin Money; emit Bills of Arts. of Con- Credit; make any Thing but gold and silver Coin
fed. vi.

a Tender in payment of Debts; pass any Bill of Attainder, ex post facto Law, or Law impairing the Obligation of Contracts, or grant any Title of Nobility.

[§2.] No State shall, without the Consent of the Congress, lay any Imposts or Duties on Imports or Exports, exeept what may be absolutely necessary for executing its inspection Laws : and the net Produce of all Duties and Imposts, laid by any State on Imports or Exports, shall be for the Use of the Treasury of the United States; and all such Laws shall be subject to the Revision and Controul of the Congress.

[§3.] No State shall, without the Consent of Congress, lay any Duty of Tonnage, keep Troops, or Ships of War in time of Peace, enter into any Agreement or Compact with another State, or with a foreign Power, or engage in War, unless actually invaded, or in such imminent Danger as will not admit of delay. 


\section{AR'TICLE. II.}

Section. I. [\$ 1.] The executive Power shall be John Quincy vested in a President of the United States of Amer- "Tdams: ica. He shall hold his Office during the Term of powers of four Years, and, together with the Vice President, the execuchosen for the same Term, be elected, as follows tive department expli-

[§ 2.] Each State shall appoint, in such Manner citly and emas the Legislature thereof may direct, a Number of phatically Electors, equal to the whole Number of Senators in one person and Representatives to which the State may be are vastly entitled in the Congress: but no Senator or Repre- sive and sentative, or Person holding an Office of 'Trust or complicated Profit under the United States, shall be appointed an Elector. than those of

[The Electors shall meet in their respective States, and vote by Ballot for two Persons, of whom one at least shall not be an Inhabitant of the same State with themselves. And they shall make a List of all the Persons voted for, and of the Number of Votes for each; which List they shall sign and certify, and transmit sealed to the Seat of the Government of the United States, directed to the President of the Senate. The President of the Senate shall, in the Presence of the Senate and House of Representatives, open all the Certificates, and the Votes shall then be counted. The Person hav- The failure ing the greatest Number of Votes shall be the Pres- to specify ident, if such Number be a Majority of the whole by whom should Number of Electors appointed; and if there be be counted more than one who have such Majority, and have led to the an equal Number of Votes, then the House of Representatives shall immediately chuse by Ballot one of them for President; and if no Person have a Majority, then from the five highest on the List the said House shall in like Manner cluuse the President. But in elusing the President, the Votes shall be taken by States, the Representation from each State having one Vote; A quorum for this Purpose shall 
consist of a Member or Members from two thirds

See Amendment xii. of the States, and a Majority of all the States shall be necessary to a Choice. In every Case, after the Choice of the President, the Person having the greatest Number of Votes of the Electors shall be the Vice President. But if there should remain two or more who have equal Votes, the Senate shall chuse from them by Ballot the Vice President.]

[§3.] The Congress may determine the Time of chusing the Electors, and the Day on which they shall give their Votes; which Day shall be the same throughout the United States.

[§ 4.] No Person except a natural born Citizen, or a Citizen of the United States at the time of the Adoption of this Constitution, shall be eligible to the Office of President; neither shall any Person be eligible to that Office who shall not have attained to the Age of thirty-five Years, and been fourteen Years a Resident within the United States.

[§5.] In Case of the Removal of the President from Office, or of his Death, Resignation or Inability to discharge the Powers and Duties of the said Office, the Same shall devolve on the Vice President, and the Congress may by Law provide for the Case of Removal, Death, Resignation, or Inability, both of the President and Vice President, declaring what Officer shall then act as President, and such Officer shall act accordingly, until the Disability be removed, or a President shall be elected.

[§6.] The President shall, at stated Times, receive for his Services, a Compensation, which shall neither be encreased nor diminished during the Period for which he shall have been elected, and he shall not receive within that Period any other Emolument from the United States, or any of them.

[§ 7.] Before he enter on the Execution of his Office, he shall take the following Oath or affirmation:-

"I do solemnly swear (or affirm) that I will faith- 
fully execute the Office of President of the United States, and will to the best of my Ability, preserve, protect, and defend the Constitution of the United States."

Secrion. 2. [\$ 1.] The President shall be Com- The warmander in Chief of the Army and Navy of the power of the United States, and of the Militia of the several may involve States, when called into the actual Service of the the country United States; he may require the Opinion, in in war withwriting, of the principal Officer in each of the ex- of Congress, ecutive Departments, upon any Subject relating to $\stackrel{\text { e.g. Mexican }}{\text { War. }}$ the Duties of their respective Offices, and he shall have Power to grant Reprieves and Pardons for Offences against the United States, except in Cases of Impeachment.

[§ 2.] He shall have Power, by and with the Advice and Consent of the Senate, to make Treaties, This power provided two thirds of the Senators present concur; dates back to and he shall nominate, and by and with the Advice the Teutonic and Consent of the Senate, shall appoint Ambassadors, other public Ministers and Consuls, Judges of the supreme Court, and all other Officers of the United States, whose Appointments are not herein tribes when the "cyning" led tribes in otherwise provided for, and which shall be established by Law : but the Congress may by Law vest the Appointment of such inferior Officers, as they think proper, in the President alone, in the Courts of Law, or in the Heads of Departments.

[§ 3.] The President shall have Power to fill up all Vacancies that may happen during the Recess of the Senate, by granting Commissions which shall expire at the Fnd of their next Session.

Section. 3. He shall from time to time give to The Presithe Congress Information of the State of the Union, dent's mesthe Congress Information of the State of the Union, sage and recommend to their Consideration such Meas- to the proures as he shall judge necessary and expedient; he cedure of may, on extraordinary Occasions, convene both municating Houses, or either of them, and in Case of Disagree- with Parment between them, with Respect to the Time of Bryce says, 
"The mes- Adjournment, he may arjourn them to such Time sage ustually discusses the leading ques- dors and other public Ministers; he shall take Care tion of the that the Laws be faithfully executed, and shall moment ... Commission all the Officers of the United States.

one of his Section. 4. The President, Vice President and ministers sits in either House to ex- removed from Office on Impeachment for, and Conplain and defend them, viction of, Treason, Bribery, or other high Crimes the message and Misdemeanors.

is a shot in the air without practical result."

\section{ARTICLE. III.}

No federa-

Section. 1. The judicial Power of the United tion had ever States, shall be vested in one supreme Court, and had a power- in such inferior Courts as the Congress may from ful national

Court. Compare with Arts. of Confed. $x x$. Sect. 2 . time to time ordain and establish. The Judges, both of the supreme and inferior Courts, shall hold their Offices during good Behaviour, and shall, at stated Times, receive for their Services, a Compensation, which shall not be diminished during their Continuance in Office.

Sectron. 2. [\$ 1.] The judicial Power shall extend to all Cases, in Law and Equity, arising under this Constitution, the Laws of the United States, and Treaties made, or which shall be made, under their Authority; - to all Cases affecting Ambassadors, other public Ministers and Consuls; - to all Cases of admiralty and maritime Jurisdiction; - to Controversies to which the United States shall be a Party; - to Controversies between two or more States; - between a State and Citizens of another State; - between Citizens of different States, between Citizens of the same State claiming Lands under Grants of different States, and between a State, or the Citizens thereof, and foreign States, Citizens or Subjects.

[§ 2.] In all Cases affecting Ambassadors, other 
public Ministers and Consuls, and those in which a State shall be Party, the supreme Court shall have original Jurisdiction. In all the other Cases before mentioned, the supreme Court shall have appellate Jurisdiction, both as to Law and Fact, with such Exceptions, and under such Regulations as the Congress shall make.

[§ 3.] The Trial of all Crimes, except in Cases Limited by of Impeachment, shall be by Jury; and such 'Trial 11th Amendshall be held in the State where the said Crimes shall have been committed; but when not committed within any State, the Trial shall be at such Place or Places as the Congress may by Law have directed.

Section. 3. [ $\$ 1$.$] Treason against the United$ States, shall consist only in levying War against them, or in adhering to their Enemies, giving them Aid and Comfort. No Person shall be convicted of Treason unless on the Testimony of two Witnesses to the same overt Act, or on Confession in open Court.

[ $\S 2$.$] The Congress shall have Power to declare$ the Punishment of Treason, but no Attainder of Treason shall work Corruption of Blood, or Forfeiture except during the Life of the Person attainted.

\section{ARTICLE. IV.}

Section. 1. Full Faith and Credit shall be given in each State to the public Acts, Records, and judicial Proceedings of every other State. And the Congress may by general Laws prescribe the Manner in which such Acts, Records and Proceedings shall be proved, and the Effect thereof.

Srction 2. [\$ 1.] The Citizens of each State shall be entitled to all Privileges and Immunities of Citizens in the several States.

[§2.] A Person charged in any State with Abridged Treason, Felony, or other Crime, who shall flee text from 
Articles of Confederation, iv. : extended by 14th Amendment.

A cause of violent controversy from 1831 to 1864 ; superseded by 13 th

Amendment.

Kentucky, Vermont, Maine, West Virginia so constituted by consent.

This article settled the question of the competence of Congress to pass the Ordinance of 1787.

Federal forces have been repeatedly called in to repress insurrections, and also at times of strikes and riots. from Justice, and be found in another State, shall on Demand of the executive Authority of the State from which he fled, be delivered up, to be removed to the State having Jurisdiction of the Crime.

[§3.] [No Person held to Service or Labour in one State, under the Laws thereof, escaping into another, shall, in Consequence of any Law or Regulation therein, be discharged from such Service or Labour, but shall be delivered up on Claim of the Party to whom such Service or Labour may be due.]

Section 3. [§ 1.] New States may be admitted by the Congress into this Union; but no new State shall be formed or erected within the Jurisdiction of any other State; nor any State be formed by the Junction of two or more States, or Parts of States, without the Consent of the Legislatures of the States concerned as well as of the Congress.

[§ 2.] The Congress shall have Power to dispose of and make all needful Rules and Regulations respecting the Territory or other Property belonging to the United States; and nothing in this Constitution shall be so construed as to Prejudice any Claims of the United States, or of any particular State.

Section 4. The United States shall guarantee to every State in this Union a Republican Form of Government, and shall protect each of them against Invasion; and on Application of the Legislature, or of the Executive (when the Legislature cannot be convened) against domestic Violence.

\section{ARTICLE. V.}

The Congress, whenever two thirds of both Houses shall deem it necessary, shall propose Amendments to this Constitution, or, on the Application of the Legislatures of two thirds of the 
several States, shall call a Convention for proposing Amenchents, which, in either Case, shall be valid to all Intents and Purposes, as Part of this Consti- This method tution, when ratified by the Legislatures of three of amending fourths of the several States, or by Conventions in the Conthree fourths thereof, as the one or the other Mode has proved of Ratification may be proposed by the Congress; cumbersome. Provided [that no Amendment which may be made of about 1700 prior to the Year One thousand eight hundred and proposed eight shall in any Manner affect the first and fourth amendments Clauses in the Ninth Section of the first Article; ratified. and] that no State, without its Consent, shall be deprived of its equal Suffrage in the Senate.

\section{AR'TICLE. VI.}

[§ 1.] All Debts contracted and Engagements entered into, before the Adoption of this Constitution, shall be as valid against the United States under this Constitution, as under the Confed- See 14th eration.

Amendment.

[§2.] This Constitution, and the Laws of the United States which shall be made in Pursuance thereof; and all Treaties made, or which shall be made, under the Authority of the United States, shall be the supreme Law of the Land; and the A splendid Judges in every State shall be bound thereby, any and powerful Thing in the Constitution or Laws of any State to clause. the Contrary notwithstanding.

[§3.] The Senators and Representatives before mentioned, and the Members of the several State Legislatures, and all executive and judicial Officers, both of the United States and of the several States, shall be bound by Oath or Affirmation, to support this Constitution; but no religious Test shall ever be required as a Qnalification to any Office or public Trust under the United States. 


\section{ARTICLE. VII.}

Technically a breach of the previous Articles of Confederation.
The Ratification of the Conventions of nine States, shall be sufficient for the Establishment of this Constitution between the States so ratifying the Same.

Dowe in Convention by the Uuanimous [Note of the Consent of the States present the Serendraughtsman as to teenth Day of September in the Year of interlineations in our Lord one thousand seven hundred and the text of the man- Eighty seven and of the Independence of uscript.]

Attest the United States of America the Twelfth In Witness whereof We have hereunto WiLliaMJACKson. subscribed our names.

Secretary.

Go WASHINGTON Presidt and deputy from Virginia.

Delaware.

North Carolina.

$\left\{\begin{array}{l}\text { GEO: READ } \\ \text { GUNNING BEDFORD jun } \\ \text { JOHN DICKINSON } \\ \text { RICHARD BASSETT } \\ \text { JACO BROOM }\end{array}\right.$

(WM. BLOUNT

$\{$ Richd. Dobbs Spaight

Hu Williamson

South Carolina

New Hampshire.

$\left\{\begin{array}{l}\text { John Langdon } \\ \text { Nicholas Gilman }\end{array}\right\}$

Massachusetts.

$\left\{\begin{array}{l}\text { J. Rutledge } \\ \text { Charles Cotesworth } \\ \quad \text { Pinckney } \\ \text { Charles Pinckney } \\ \text { Pierce Butler }\end{array}\right.$

$\{$ Nathaniel Gorham

$\{$ Rufus King

Georgia. $\left\{\begin{array}{l}\text { William Few } \\ \text { Abr Baldwin }\end{array}\right.$

Maryland.

$\int$ James McHenry

Dan of St. Thos. JenIFER

Danl Carroll

Connecticut.

$\{$ Wm. Saml. Johnson $\{$ Roger Sherman

Virginia.

S John Blair -

New York.

$\{$ JaMes Madison Jr. 
New Jersey. $\left\{\begin{array}{l}\text { Wil : Livingston } \\ \text { David Brearley } \\ \text { Wai : Paterson. } \\ \text { Jona: Dayton }\end{array}\right.$
Pennsylvania.

$\left\{\begin{array}{l}\text { B Franklin } \\ \text { Thomas Mifflin } \\ \text { Robt. Morris } \\ \text { Geo. Clymer } \\ \text { Thos. FItz Sinons } \\ \text { Jared Ingersold } \\ \text { JaMes Wilson. } \\ \text { Gouv Morris }\end{array}\right.$

\section{AMENDMENTS.}

\section{[ARTICLE I.]}

Congress shall make no law respecting an establishment of religion, or prohibiting the free exercise thereof; or abridging the freedom of speech, or of the press; or the right of the people peaceably to assemble, and to petition the Government for a re- The first ten dress of grievances.

\section{[ARTICLE II.]}

amendments were adopted at one time (Sept. 25,

A well regulated Militia, being necessary to the $\frac{1789) ; \text { and }}{\text { declared in }}$ security of a free State, the right of the people to force Dec. 15, keep and bear Arms, shall not be infringed.

\section{[AR'TICLE III.]}

1791. They satisfied the popular demand for a Bill of

No Soldier shall, in time of peace be quartered Rights. See in any house, without the consent of the Owner, nor Petition of in time of war, but in a manner to be prescribed by $x i$. Bill of law.

Rights (12).

\section{[ARTICLE IV.]}

The right of the people to be secure in their persons, houses, papers, and effeets, against unreasonable searehes and seizures, shall not be violated, and no Warrants shall issue, but upon probable eause, supported by Oath or affirmation, and particularly deseribing the place to be searched, and the persons or things to be seized. 


\section{[ARTICLE V.]}

No person shall be held to answer for a capital, or otherwise infamous crime, unless on a presentment or indictment of a Grand Jury, except in cases arising in the land or naval forces, or in the Militia, when in actual service in time of War or public danger; nor shall any person be subject for the same offence to be twice put in jeopardy of life or limb; nor shall be compelled in any criminal case to be a witness against himself, nor be deprived of life, liberty, or property, without due process of law; nor shall private property be taken for public use, without just compensation.

\section{[ARTICLE VI.]}

Amendments In all criminal prosecutions the accused shall v. to xi. restate English Common Law, and Magna Charta. enjoy the right to a speedy and public trial, by an impartial jury of the State and district wherein the crime shall have been committed, which district shall have been previously ascertained by law, and to be informed of the nature and cause of the accusation; to be confronted with the witnesses against him ; to have compulsory process for obtaining witnesses in his favour, and to have the Assistance of Counsel for his defence.

\section{[ARTICLE VII.]}

In suits at common law, where the value in controversy shall exceed twenty dollars, the right of trial by jury shall be preserved, and no fact tried by a jury shall be otherwise re-examined in any Court of the United States, than according to the rules of the common law.

\section{[ARTICLE VIII.]}

Excessive bail shall not be required, nor excessive fines imposed, nor cruel and unusual punishments inflicted. 


\section{[ARTICLE IX.]}

The enumeration in the Constitution, of certain rights, shall not be construed to deny or disparage others retained by the people.

\section{[ARTICLE X.]}

The powers not delegated to the United States by the Constitution, nor prohibited by it to the States, are reserved to the States respectively or to the people.

\section{[ARTICLE XI.]}

The Judicial power of the United States shall not Proposed be construed to extend to any suit in law or equity, March 5, commenced or prosecuted against one of the United clared in States by Citizens of another State, or by Citizens force Jan. 8, or Subjects of any Foreign State.

\section{[ARTICLE XII.]}

The Electors shall meet in their respective states, Proposed and vote by ballot for President and Vice-President, Dec. 12,1803. one of whom, at least, shall not be an inhabitant of force Sept. the same state with themselves; they shall name in 25,1804 . their ballots the person voted for as President, and To prevent in distinct ballots the person voted for as Vice- ties and President, and they shall make distinct lists of all dead-locks. persons voted for as President, and of all persons voted for as Vice-President, and of the number of votes for each, which lists they shall sign and certify, and transmit sealed to the seat of the government of the United States, directed to the President of the Senate; - The President of the Senate shall, in the presence of the Senate and House of Representatives, open all the certificates and the votes shall then be counted; - The person having the greatest number of votes for President, shall be the President, if such number be a majority of the 
whole number of Electors appointed; and if no person have such majority, then from the persons having the highest numbers not exceeding three on the list of those voted for as President, the House of Representatives shall choose immediately, by ballot, the president. But in choosing the President, the votes shall be taken by states, the representation from each state having one vote; a quorum for this purpose shall consist of a member or members from two-thirds of the states, and a majority of all the states shall be necessary to a choice. And if the House of Representatives shall not choose a President whenever the right of choice shall devolve upon them, before the fourth day of March next following, then the Vice-President shall act as President, as in the case of the death or other constitutional disability of the President. - The person having the greatest number of votes as VicePresident, shall be the Vice-President, if such number be a majority of the whole number of Electors appointed, and if no person have a majority, then from the two highest numbers on the list, the Senate

In the original manuscripts these twelve Amendments have no numbers. Amendments xiii.-xv. appear in Ch. $x \times i$. below. shall choose the Vice-President: a quorum for the purpose shall consist of two-thirds of the whole number of Senators, and a majority of the whole number shall be necessary to a choice. But no person constitutionally ineligible to the office of President shall be eligible to that of Vice-President of the United States.

\section{CONTEMPORARY EXPOSITION}

FRANKIIN (1787)

Monday, September 17. - In Convention. - The engrossed Coustitution being read, Doctor Franklin rose with a speech in his hand, which he had reduced to writing for his own convenience, and which $\mathrm{Mr}$. Wilson read in the words following:-

"Mr. President : I confess that there are several parts of this Constitution which I do not at present approve, but I am 
not sure I shall never approve them. For having lived long, I have experienced many instances of being obliged by better information, or fuller consideration, to change opinions even on important subjects which I once thought right, but found to be otherwise. It is therefore that, the older I grow, the more apt I am to doubt my own judgment, and to pay more respect to the judgment of others. Most men, indeed, as well as most sects in religion, think themselves in possession of all truth, and that wherever others differ from them it is so far error. Steele, a Protestant, in a dedication, tells the Pope, that the only difference between our churches, in their opinions of the certainty of their doctrines, is, "the Church of Rome is infallible, and the Church of England is never in the wrong.' But though many private persons think almost as highly of their own infallibility as of that of their sect, few express it so naturally as a certain French lady who, in a dispute with her sister, said, 'I don't know how it happens, sister, but I meet with nobody but myself that is always in the right-il n'y a que moi a toujours raison.'

"In these sentiments, sir, I agree to this Constitution, with all its faults, if they are such; because I think a General Government necessary for us, and there is no form of goverument but what may be a blessing to the people if well administered; and believe further, that this is likely to be well administered for a course of years, and can only end in despotism, as other forms have done before it, when the people shall become so corrupted as to need despotic government, being incapable of any other. I dloubt, too, whether any other Convention we can obtain may be able to make a better Constitution, for when you assemble a number of men to have the advantage of their joint wisdom, you inevitably assemble with those men all their prejudices, their passions, their errors of opinion, their local interests, and their selfish views. From such an assembly can a perfect production be expected? It therefore astonishes me, sir, to find this system approaching so near to perfection as it does; and I think it will astonish our enemies, who are waiting with confidence to hear that our councils are confounded, like those of the builders of Babel; and that our States are on the point of separation, only to meet hereafter for the purpose of 
cutting one another's throats. Thus I consent, sir, to this Constitution, because I expect no better, and because I am not sure that it is not the best. 'The opinions I have had of its errors I sacrifice to the public good. I have never whispered a syllable of them abroad. Within these walls they were born and here they shall die. If every one of us, in returning to our constituents, were to report the objections he has had to it, and endeavour to gain partizans in support of them, we might prevent its being generally received, and thereby lose all the salutary effects and great advantages resulting naturally in our favour among foreign nations as well as among ourselves, from our real or apparent unanimity. Much of the strength and efficiency of any government, in procuring and securing happiness to the people, depends on opinion - on the general opinion of the goodness of the government as well as of the wisdom and integrity of its governors. I hope, therefore, that for our own sakes, as a part of the people, and for the sake of posterity, we shall act heartily and unanimously in recommending this Constitution (if approved by Congress and confirmed by the Conventions) wherever our influence may extend, and turn our future thoughts and endeavours to the means of having it well administered.

" On the whole, sir, I cannot help expressing a wish that every member of the Convention, who may still have objections to it, would, with me, on this occasion doubt a little of his own infallibility, and, to make manifest our unanimity, put his name to this instrument."

He then moved that the Constitution be signed by the members, and offered the following as a convenient form, viz.; "Done in Convention by the unanimous consent of the States present, the seventeenth of September, \&c. In witness whereof we have hereunto subscribed our names." This ambiguons form had been drawn up by Mr. Gouverneur Morris, in order to gain the dissenting members, and put into the hands of Doctor Franklin that it might have the better chance of success. . . .

The Constitution being signed by all the members except $\mathrm{Mr}$. Randolph, Mr. Mason and Mr. Gerry, who declined giving it the sanction of their names, the Convention dissolved itself by an adjournment sine die. 
Whilst the last members were signing, Doctor Franklin, looking towards the President's chair, at the back of which a rising sun happened to be painted, observed to a few members near him that painters had found it difficult to distinguish, in their art, a rising, from a setting, sun. I have, said he, often and often, in the course of the session, and the vicissitudes of my hopes and fears as to its issue, looked at that behind the President, without being able to tell whether it was rising or setting; but now, at length, I have the happiness to know, that it is a rising, and not a setting, sun.

Benjamin Franklin in Henry D. Gilpin's Madison Papers. III. 1596-1624.

\section{MASON (1787).}

There is no declaration of rights ... In the House of Representatives there is not the substance, but the shadow only of representation. . . The Senate have the power of altering all money-bills, and of originating appropriations of money... although they are not the representatives of the people. ...

The judiciary of the United States is so constructed and extended as to absorb and destroy the judiciaries of the several States. . . The President of the United States has no constitutional council; he will therefore be unsupported by proper information and advice. . . .

This government will commence in a moderate aristocracy; it is at present impossible to foresee whether it will in its operation produce a monarchy or a corrupt oppressive aristocracy; it will most probably vibrate some years between the two, and then terminate in the one or the other.

George Mason, Address to the Citizens of Virginia, in P. L. Ford, Pamphlets on the Constitution. $329,332$.

\section{THE FEDERALIST (1787)}

If the new Constitution be examined with accuracy and candour, it will be found that the change which it proposes consists much less in the addition of New Powers to the Union, than in the invigoration of its Original Powers. The regulation of commerce, it is true, is a new power; but that seems to be 
an addition which few oppose, and from which no apprehensions are entertained. The powers relating to war and peace, armies and fleets, treaties and finances, with the other more considerable powers, are all vested in the existing Congress by the articles of Confederation. The proposed change does not enlarge these powers; it only substitutes a more effectual mode of administrating them. The change relating to taxation may be regarded as the most important; and yet the present Congress have as complete authority to REQuine of the States indefinite supplies of money for the common defence and general welfare, as the future congress will have to require them of individual citizens; and the latter will be no more bound than the States themselves have been, to pay the quotas respectively taxed on them. Had the States complied punctually with the articles of Confederation, or could their compliance have been enforced by as peaceable means as may be used with success towards single persons, our past experience is very far from countenancing an opinion, that the State governments would have lost their constitutional powers, and have gradually undergone an entire consolidation. To maintain that such an event would have ensued, would be to say at once, that the existence of the State governments is incompatible with any system whatever that accomplishes the essential purposes of the Union.

Alexander Hamilton in The Federalist. No. xlv. 291.

HAMILTON (1787)

The new Constitution has in favour of its success these circumstances. A very great weight of influence of the persons who framed it, particularly in the universal popularity of General Washington. The good-will of the commercial interest throughout the States, which will give all its efforts to the establishment of a government capable of regulating, protecting, and extending the commerce of the Union. The good will of most men of property in the several States, who wish a government of the Union able to protect them against domestic violence, and the depredations which the democratic spirit is apt to make on property, and who are besides anxious 
for the respectability of the nation. The hopes of the creditors of the United States, that a general government possessing the means of doing it, will pay the debt of the Union. A strong belief in the people at large of the insufficiency of the present Confederation to preserve the existence of the Union, and of the necessity of the Union to their safety and prosperity; of course, a strong desire of a change, and a predisposition to receive well the propositions of the convention.

Against its success is to be put the dissent of two or three important men in the convention, who will think their characters pledged to defeat the plan; the influence of many inconsiderable men in possession of considerable offices under the State governments, who will fear a diminution of their consequence, power, and emolument, by the establishment of the general government, and who can hope for nothing there; the influence of some considerable men in office, possessed of talents and popularity, who, partly from the same motives, and partly from a desire of playing a part in a convulsion for their own aggrandizement, will oppose the quiet adoption of the new government (some considerable men out of office, from motives of ambition, may be disposed to act the same part). Add to these canses the disinclination of the peoplc to taxes, and of course to a strong government; the opposition of all men much in debt, who will not wish to see a government established, one object of which is to restrain the means of cheating creditors; the democratical jealousy of the people, which may be alarmed at the appearance of institutions that may seem calculated to place the power of the community in few hands, and to raise a few individuals to stations of great pre-eminence; and the influence of some foreign powers, who, from different motives, will not wish to see an energetic government established throughout the States.

Alexander Hamiton, Works. I. 400-402.

WASHINGTON (1787)

To Patrick Hexry.

Mount Vernon, 24, September, 1787.

Dear Sir, - In the first moment after my return, I take the liberty of sending you a copy of the constitution, which 
the federal convention has submitted to the people of these States. I accompany it with no observations. Your own judgment will at once discover the good and the exceptionable parts of it; and your experience of the difficulties, which have ever arisen when attempts have been made to reconcile such variety of interests and local prejudices, as pervade the several States, will render explanation unnecessary. I wish the constitution, which is offered, had been made more perfect; but I sincerely believe it is the best that could be obtained at this time. And, as a constitutional door is opened for amendment hereafter, the adoption of it, under the present circumstances of the Union, is in my opinion desirable.

From a variety of concurring accounts it appears to me, that the political concerns of this country are in a manner suspended by a thread, and that the convention has been looked up to, by the reflecting part of the community, with a solicitude which is hardly to be conceived; and, if nothing had been agreed on by that body, anarchy would soon have ensued, the seeds being deeply sown in every soil.

George Washington, Works. XI. 164, 165.

WASHINGTON (1788)

To the Marquis de Lafayette.

Mount Vernon, February 7, 1788.

My Dear Marquis, .. As to my sentiments with respect to the merits of the new constitution, I will disclose them without reserve, (although by passing through the postoffice they should become known to all the world,) for in truth I have nothing to conceal on that subject. .It appears to me, then, little short of a miracle, that the delegates from so many different States, (which States yon know are also different from each other,) in their manners, eircumstances, and prejudices, should unite in forming a system of national government, so little liable to well-founded objections. Nor am I yet such an enthusiastic, partial, or undiscriminating admirer of it, as not to perceive it is tinctured with some real (though not radical) defects. ... With regard to the two great points (the pirots 
upon which the whole machine must move), my creed is simply, 1st. That the general government is not invested with more powers, than are indispensably necessary to perform the funetions of a good government; and consequently that no objection ought to be made against the quantity of power delegated to it.

2 dly. That these powers . . . are so distributed among the legislative, executive, and judicial branches into which the general government is arranged, that it can never be in danger of degenerating into a monarehy, an oligarchy, an aristocracy, or any other despotic or oppressive form, so long as there shall remain any virtue in the body of the people. . . .

George Washingtov, Works. XI. 218, 219.

\section{DICKINSON (1788)}

Some of our fellow-citizens have ventured to predict the future of Uniter America, if the system proposed to us, shall be adopted.

Though every branch of the constitution and government is to be popular, and guarded by the strongest provisions that until this day have oceurred to mankind, yet the system will end, they say, in the oppressions of a monarchy, or aristocracy by the federal servants or some of them. . . .

The proposed confederation offers to us a system of diversified representation in the legislative, executive, and judicial departments as essentially necessary to the good government of an extensive republican empire. Every argument to recommend it, receives new force, by contemplating events that must take place. The number of states in America will increase. If not united to the present, the consequences are evident; if uniterl it must be by a plan that will communicate equal liberty and assure just protection to them.

Jorrs Dickinsos, in P. L. Ford's Pamphlets on the Constitution. 195, 204.

\section{$\operatorname{CoxE}(1788)$}

The people will remain, under the proposed constitution, the fountain of power and public honour. The President, the Senate, and the House of Representatives, will be the channels 
through which the stream will flow - but it will flow from the people, and from them only.

Every office, religious, civil and military will be either their immediate gift or it will come from them through the hands of their servants.

And this, as observed before, will be guaranteed to them under the state constitution which they respectively approve; for they cannot be royal forms, cannot be aristocratical, but must be republican. ...

There is no spirit of arrogance in the new federal constitution. It addresses you with becoming modesty, admitting that it may contain errors. Let us give it a trial; and when experience has taught its mistakes, the people, whom it preserves absolutely all powerful, can reform and amend them. That I may be perfectly understood, I will acknowledge its acceptance by all the states, without delay is the second wish of my heart. The first is, that our country may be virtuous and free.

'Texch Coxe, in P. I. Ford's Pamphlets on the Constitution. 147, 153, 154.

JEFFERSON (1821)

This Convention met at Philadelphia on the 25th of May, '87. It sat with closed doors, and kept all its proceedings secret, until its dissolution on the 17th of September, when the results of its labours were published all together. I received a copy, early in November, and read and contemplated its provisions with great satisfaction. As not a member of the Convention, however, nor probably a single citizen of the Union, had approved it in all its parts, so I, too, found articles which I thought objectionable. The absence of express declarations ensuring freedom of religion, freedom of the press, freedom of the person under the uninterrupted protection of the Habeas corpus, and trial by jury in Civil as well as in Criminal cases, excited my jealousy; and the re-eligibility of the President for life, I quite disapproved. I expressed freely, in letters to my friends, and most particularly to Mr. Madison and General Washington, my approbations and objections. How the good should be secured and the ill brought to rights was the difficulty. To refer it back to a new Convention might endanger the loss of the whole. My first idea was, that the nine States first acting, 
should accept it unconditionally, and thus secure what in it was good, and that the four last should accept on the previous condition, that certain amendments should be agreed to; but a better course was devised, of accepting the whole, and trusting that the good sense and honest intentions of our citizens, would make the alterations which should be deemed necessary.

Thomas Jefrerson, Works. I. 79.

\section{CRITICAL COMMENT}

WEBSTER (1833)

The Constitution of the United States, founded in or on the consent of the people, may be said to rest on compact or consent; but it is not itself the compact, but its result. When the people agree to erect a government, and actually erect it, the thing is done, and the agreement is at an end. The compact is executed, and the end designed by it attained. Henceforth, the fruit of the agreement exists, but the agreement itself is merged in its own accomplishment; since there can be no longer a subsisting agreement or compact to form a constitution or government, after that constitution or government has been actually formed and established. . . .

The Constitution, Sir, legards itself as perpetual and immortal. It seeks to establish a union among the people of the States, which shall last through all time. . . . It is the association of the people, under a constitution of goverument, uniting their power, joining together their highest interests, cementing their present enjoyments, and blending, in one indivisible mass, all their hopes for the future. Whatsoever is steadfast in just political principles; whatsoever is permanent in the structure of hnman socicty; whatsoever there is which can derive an enduring character from being founded on deep-laid principles of constitutional liberty, and on the broad foundations of the public will, - all these unite to entitle this instrument to be regarded as a permanent constitution of government.

Daniel Webster, Works. III. 468, 478. 


\section{STORY (1833)}

In our futare commentaries upon the constitution we shall treat it, then, as it is denominated in the instrument itself, as a constitution of government, ordained and established by the people of the United States for themselves and their posterity. They have declared it the supreme law of the land. 'They have made it a limited government. They have defined its authority. They have restrained it to the exercise of certain powers, and reserved all others to the states or to the people. It is a popular government. Those, who administer it, are responsible to the people. It is as popular, and just as much emanating from the people, as the state governments. It is created for one purpose; the state governments for another. It may be altered, and amended, and abolished at the will of the people. In short, it was made by the people, made for the people, and is responsible to the people. ...

The constitution of the United States is to receive a reasonable interpretation of its language, and its powers, keeping in view the objects and purposes, for which those powers were conferred. By a reasonable interpretation, we mean, that in case the words are susceptible of two different senses, the one strict, the other more enlarged, that should be adopted, which is most consonant with the apparent objects and intent of the constitution; that which will give it efficacy and force, as a government, rather than that, which will impair its operations, and reduce it to a state of imbecility. Of course we do not mean, that the words for this purpose are to be strained beyond their common and natural sense ; but keeping within that limit, the exposition is to have a fair and just latitude, so as on the one hand to avoid obvious mischief, and on the other hand to promote the public good. . . .

But a constitution of goverument, founded by the people for themselves and their posterity, and for objects of the most momentous nature, for perpetual union, for the establishment of justice, for the general welfare, and for a perpetuation of the blessings of liberty, necessarily requires, that every interpretation of its powers should have a constant reference to these objects. No interpretation of the words, in which those pow- 
ers are granted, can be a sound one, which narrows down their ordinary import, so as to defeat those objects.

Joseph Storr, Commentaries on the Constitution of the United States. 134, 139,141 .

GLADSTONE (1878)

The students of the future, in this department [political philosophy], will have much to say in the way of comparison between American and British institutions. The relationship between these two is unique in history. It is always interesting to trace and to compare Constitutions, as it is to compare languages; especially in such iustances as those of the Greek States and the Italian Republics, or the diversified forms of the feudal system in the different countries of Europe. But there is no parallel in all the records of the world to the case of that prolific British mother, who has sent forth her innumerable children over all the earth to be the founders of halfa-dozen empires. She, with her progeny, may almost claim to constitute a kind of Universal Church in politics. But, among these children, there is one whose place in the world's eyes and in history is superlative : it is the American Republic. She is the oldest born. She has, taking the capacity of her land into view as well as its mere measurement, a natural base for the greatest continuous empire ever established by man.

... And for the political student all over the world, it will be beyond anything curious as well as useful to examine, with what diversities, as well as what resemblances, of apparatus, the two greater branches of a race born to command have been minded, or induced, or constrained to work out, in their sea-severed seats, their political destinies according to the respective laws appointed for them....

There were, however, the strongest reasons why America could not grow into a reflection or repetition of England. Passing from a narrow island to a continent almost without bounds, the colonists at once, and vitally, altered their conditions of thought, as well as of existence, in relation to the most important and most operative of all social facts, the possession of the soil.... 
It is to the honour of the British monarchy that, upon the whole, it frankly recognized the facts, and did not pedantically endeavour to constrain by artificial and alien limitations the growth of the infant States. It is a thing to be remembered that the accusations of the colonies in 1776 were entirely levelled at the King actually on the throne, and that a general acquittal was thus given by them to every preceding reign. Their infancy had been upon the whole what their manhood was to be, self-governed and republican. Their Revolution, as we call it, was like ours in the main, a vindication of liberties inherited and possessed. It was a Conservative revolution; and the happy result was that, notwithstanding the sharpness of the collision with the mother-country, and with domestic loyalism, the 'Thirteen Colonies made provision for their future in conformity, as to all that determined life and manners, with the recollections of their past. The two constitutions of the two countries express indeed rather the differences than the resemblances of the nations. The one is a thing grown, the other a thing made; the one a praxis, the other a poiesis; the one the offspring of tendency and indeterminate time, the other of choice and of an epoch. But, as the British Constitution is the most subtle organism which has proceeded from the womb and the long gestation of progressive history, so the American Constitution is, so far as I can see, the most wonderful work ever struck off at a given time by the brain and purpose of man. It has had a century of trial, under the pressure of exigencies caused by an expansion unexampled in point of rapidity and range: and its exemption from formal change, though not entire, has certainly proved the sagacity of the constructors, and the stubborn strength of the fabric.

Willina Ewart Gladstone, Kin Beyond Sea in Gleanings of Past Years. I. 204-212.

\section{COOLEY (1880)}

In America the leading principle of constitutional liberty has from the first been, that the sovereignty reposed in the people; and as the people could not in their collective capacity exercise the powers of government, a written constitution was by general consent agreed upon in each of the States. These constitutions 
create departments for the exercise of sovereign powers; prescribe the extent of the exercise, and the methods, and in some particulars forbid that certain powers which would be within the compass of sovereignty shall be exercised at all. . . . The constitution, moreover, is in the nature of a covenant of the sovereign people with each individual thereof, under which, while they intrust the powers of government to political agencies, they also divest themselves of the sovereign power of making changes in the fundamental laws except by the method in the constitution agreed upon. The Constitution of the United States creates similar governmental trusts and imposes similar restrictions. ...

The government created by the Constitution is one of limited and enumerated powers, and the Constitution is the measure and the test of the powers conferred. Whatever is not conferred is withheld, and belongs to the several States or to the people thereof. As a constitutional principle this must result from a consideration of the circumstances under which the Constitution was formed. The States were in existence before, and possessed and exercised nearly all the powers of sovereignty. The Union was in existence, but the Congress which represented it possessed a few powers only conceded to it by the States, and these circumscribed and hampered in a manner to render them of little value. . . . But it was not within the intent of those who formed the Constitution to revolutionize the States, to overturn the presumptions that supported their authority, or to create a new government with uncertain and undefined powers. The purpose, on the contrary, was to perpetuate the States in their integrity, and to strengthen the union in order that they might be perpetuated. . . . By Art. VI. it is declared that " This Constitution and the laws of the United States which shall be made in pursuance thereof, and all treaties made, or which shall be mare, under the authority of the United States, shall be the supreme law of the land; and the judges in every State shall be bound thereby, anything in the Constitution or laws of any State to the contrary notwithstanding." Upon this it is to be observed :-

(1) The Congress of the United States derives its power to legislate from the Constitution, which is the measure of its authority; and any enactment of Congress which is opposed to 
its provisions, or is not within the grant of powers made by it, is unconstitutional, and therefore no law, and obligatory upon no one.

(2) As between a law of the United States made in pursuance of the Constitution and a treaty made under the authority of the United States, if the two in any of their provisions are found to conflict, the one last in point of time must control. For the one as well as the other is an act of sovereignty, differing only in form and in the organ or agency through which the sovereign will is declared. Each alike is the law of the land in its adoption, and the last law must repeal everything that is of no higher autbority which is found to come in eonflict with it. A treaty may therefore supersede a prior act of Congress; and, on the other hand, an act of Congress may supersede a prior treaty.

(3) A State law must yield to the supreme law, whether expressed in the Constitution of the United States, or in any of its laws or treaties, so far as they come in collision, and whether it be a law in existence when the "supreme law" was adopted or enacted afterward. The same is true of any provision in the constitution of any State which is found to be repugnant to the Constitution of the Union. And not only must " the judges in every State" be bound by such supreme law, but so must the State itself, and every official in all its departments, and every citizen.

(4) The Constitution itself never yields to treaty or enactment; it neither changes with time, nor does it in theory bend to the force of circumstances. It may be amended according to its own permission; but while it stands it is "a law for rulers and people, equally in war and in peace, and covers with the shield of its protection all classes of men, at all times and under all circumstances." Its principles cannot, therefore, be set aside in order to meet the supposed necessities of great crises.

Thomas M. Cooley; Constitutional Law. 22-32.

\section{J. C. HURD (1881)}

The Revolutionary or Continental Congress, July 4, 1776, declared the "United Colonies" to be free and independent States, "in the name and by the authority of the good people of 
these colonies." But the delegates to that Congress, before as well as after the establishment of State governments, had received their appointment from electoral agencies which, in their connection with the people whom they claimed to represent, were very different in the various colonies.

In the government, under the Articles of Confederation, the united political people of the States exercised their power for general national purposes, by the intervention of the same organs by which they exercised power for local or State purposes.

In the government, under the Constitution, the same political people, without a revolution, $i$. e., without any shifting of sovereign power, exercised their powers for national purposes by the immediate action, through special representatives, of the political people of each State.

The possession by this "people of the United States" of the powers exerted by a general government, co-existent with the possession by the same people of other powers, exerted by the State governments, continued, in manner and form more or less distinctly recognized, from the time of the Revolution onward; and, prior to the late civil war, no political people or body politic had appeared, on the territory recognized by foreign nations from time to time as belonging to the United States, in any public international relation, except as one of the United States, or been recognized by foreign nations or by any State of the Union as using or holding in severalty the powers exerted by the general government.

Joun C. HURD, The Theory of our National Existence. 134, 135.

\section{E. P. SMITH (1889)}

In ample season for discussion and action before the adjournment of the first session of the first Congress, Madison presented a selection of the most desirable amendments suggested by the ratifying States. The changes most widely called for sacrificed nothing vital to the success of the new instrument. They rendered the Constitution its own expounder; they concentrated all the tenets of liberty in Magna Charta, the Petition of Right, and the Bill of Rights. The prompt action of the States in ratifying ten out of the twelve amendments submitted 
by Congress proved that these amendments were needed, and that the efforts of the anti-Federalists for a second constitutional convention were not fruitless or unreasonable. . . .

The amendments once ratified, all notes of opposition were lost in the chorus of admiration that resounded from every quarter. In the worship of the Constitution that instantly succeeded, men forgot that " it had been extorted from the grinding necessity of a reluctant people." Even those who had so powerfully contended for a second constitutional convention began during Washington's first administration to prove as preeminently "the friends of the Constitution," and it was almost impossible to believe that an instrument, accepted by all parties as the last word of political wisdom, had been produced in a conflict of opinion, adopted with doubt, ratified with hesitation, and amended with difficulty.

Fowakd P. Sмгтн, in J. F. Jameson's Essays on the Constitutional History of the United States. 111, 115.

\section{HART (1891)}

During the first few years of its existence the Constitution was most fortunately administered by those who had framed it, believed in it, and had the wisdom to apply it. Men like Hamilton and Washington shaped a series of organizing acts which proved but less important than the original text. Then came a period of nearly a quarter of a century (1793-1815), when the Republic was involved in foreign complications, including an annexation of territory larger than its original area, and ending in a war; the power over foreign affairs was thus consolidated. The next twenty years (1815-1835) was a time of great commercial growth, and public sentiment favored the application of national powers, both of creation and regulation. A bank was secured; internal improvements applied; commercial treaties were negotiated; and the protective policy was initiated. Then came (1835-1860) a period of great effort to restrict federal powers, partly on principle, and partly lest those powers should be used against slavery. . .

. . . The Constitution of 1789 has therefore undergone great changes, most of them in the direction of greater centralization. Amendments have rarely been necessary, because each 
generation has found the general principles laid down sufficient to give the government power to deal with new questions which come before it. The elasticity and flexibility of the Constitution have not only preserved the federation, but have introduced a new principle into federal government. A Constitution framed for four millions of people, grouped in thirteen thinly populated rural States, suffices for sixty-three millions, in forty-four rich States, abounding in cities. The permanence of the United States is not due to the constructive skill of its founders; it rests upon the fact that the Constitution may, by the insensible effect of public opinion, slowly be expanded, within the forms of law, to a settlement of new questions as they arise.

Albert Bushnell Hart, Federal Government. 59, 60.

STEVENS (1894)

On the whole, Americans, with their democratic tendencies, owe very much of the stability of their government to the weakness of their legislature and the strength of their execntive. Had Congress possessed the power of Parlianent to alter constitutional principle itself, by a majority vote at any session, and had the cabinet controlled the President as the English cabinet does the sovercign, the American commonwealth very probably might have been wrecked in its eonstructive period, or in passing through the storms of later time. The presidency is justly regarded by Americans as one of the most valuable creations of the Constitution of 1787. And the fact that the office is rooted in the past institutions of the race is not only the explanation of its existence, but a real, even though unrecognized, cause of its hold on the national heart. ...

But as soon as the draft of the Constitution left the Convention, the lack of a formal bill was severely and persistently criticised by the people. And the promise that one should be added, as soon as the new government actually got under way, was found necessary in order to induce some of the principal States to ratify the instrument. 'The first ten amendments, therefore, were adopted as speedily as possible by the first Congress and the nation; and to all intents they are to be regarded as a part of the Constitution in 
its original unity, as a product of the formative period. Their position in this respect is essentially different from that of the amendments, which are the outcome of subsequent national experience.

Thus there is not only a bill of rights in the Constitution of the United States, but that bill of rights was consciously demanded by the American people themselves against the judgment of their own Constitutional Convention, and for the express reason that they regarded the liberties included therein as their liberties, because based upon old English law.

C. Ellis Stevens, Sources of the Constitution of the United States. 173, 213.

BRYCE (1896)

The Constitution of 1789 deserves the veneration with which the Americans have been accustomed to regard it. It is true that many criticisms have been passed upon its arrangement, upon its omissions, upon the artificial character of some of the institutions it creates. Recognizing slavery as an institution existing in some States, and not expressly negativing the right of a State to withdraw from the Union, it has been charged with having contained the germ of civil war, though that germ took serenty years to come to maturity. And whatever success it has attained must be in large measure ascribed to the political genius, ripened by long experience, of the Anglo-American race, by whom it has been worked, and who might have managed to work even a worse-drawn instrument. Yet, after all deductions, it ranks above every other written constitntion for the intrinsic excellence of its scheme, its adaptation to the circumstances of the people, the simplicity, brevity, and precision of its language, its judicious mixture of definiteness in principle with elasticity in details. One is therefore induced to ask, before proceeding to examine it, to what causes, over and above the capacity of its authors, and the patient toil they bestowed upon it, these merits are due, or in other words, what were the materials at the command of the Philadelphia Convention for the achievement of so great an enterprise as the creation of a nation by means of an instrument of government. 'The American Constitution is no exception to the rule that everything which has power to win the obedience and respect of men must 
have its roots deep in the past, and that the more slowly every institution has grown, so much the more enduring is it likely to prove. There is little in this Constitution that is absolutely new. There is much that is as old as Magna Charta.

James Bryce, American Commonwealth.1 13-14.

THORPE (1898)

The State has been conserved, and the purposes for which the constitutions were framed - typically set forth in the preamble to the national Constitution - have been fairly well realized. Statesmen of the eighteenth century would impute this to the efficacy of the system of checks and balances. By this they meant the distinct functions of the executive, the legislative, and the judiciary; the different ways in which they are chosen; the different times when they hand over their power to their successors; the peculiar combination of the legislative and the executive in the administration of government, and the ultimate responsibility of all public servants to the electors. This correlation of parts and functions is the peculiarity of the American system. Though arbitrary and ever subject to modification at the will of the people, the system has been tried with success, has never departed from the principles on which it was founded, and has strengthened the conservatism which ever underlies American politics. One commenting on government in America to-day would not be likely to call attention to, much less to emphasize, the system of checks and balances. He would attribute the virtuc of our institutions to economic and sociological causes. He would dwell on the people, not on the system. He would analyze political parties, public opınion, and our social institutions. He would not be likely even to use the terms checks and balances. In the eighteenth century goverument was conceived as a device; in our times it is thought of rather as an organism. It is the content, not the language, of the Constitution that has changed. The supreme law, as time goes on, is given more and more an economic interpretation. If adapted to the wants of the country, such interpretation becomes a party doctrine, and if adopted by the majority, it becomes an administrative measure. If it is believed to in-

1 Copyright, 1896, by the Macmillan Co. 
volre essential rights, it may become a part of a revised constitution. 'Thus, at last, the constitutions beeome the depository of settled politics and the register of the growth of the State.

Fraxcis N. 'Thorpe, A Constitutional History of the American People. ${ }^{1} \quad 46,47$.

MCLAUGHLIN (1900)

It has seemed to me, however, that sufficient attention is not commonly paid to the influence and bearing of these basic principles of political philosophy in the period sueceeding the Rev. olution. The foundation doctrines everywhere current during the Revolutionary time were not likely to disappear at once, for on them rested the right of rebellion, through them came independence, upon them was founded national existence. We might be willing to assert without investigation, that the ideas which men cherished and the philosophy upon which they acted would be sure to affect the thoughts and activities of public men during the early constitutional period and for many years after the establishment of the Uniter States. It is certainly important for us to understand the ideas which men held concerning the nature and origin of the state and society, and to know the foundatious upon which they believed government to rest.

... When the constitution of the United States was being made, men did not speak or think in the terms of the organic philosophy. Some of them, it is true, were more or less distinctly conscious of the essential oneness of the American people; some of them believed that the states never had been sovereign; some of them, seeing the fact of nationality, demanded that political organization should be in keeping with this fact. But the organic philosophy was developed in the next century, and like all philosophy it came not from the thinking of the closeted philosopher, but from the actual development of society.

. . I I mean simply to assert that if we seek to follow out historically the interpretation of the Constitution or to find out what men thought of it at the beginning, we must get into their attitude of mind and understand their method of thinking.

. . The constitutional history of the United States is in no

1 Copyright, 1898, by Harper \& Brothers. 
small degree taken up with tracing opinion and assertion as to the actual character of the Union; and the historian is compelled to notice the change which took place in the opinions, words and thoughts of statesmen as they were influenced by the change in society and by the prevalence or growth of doctrines as to the origin and nature of the State.

... My purpose in this paper has been to show: (1) That the men of one hundred and twenty-five years ago thought within the limits of the compact philosophy; (2) That they carried the compact idea so far that they actually spoke of the Constitution as a social compact; (3) That it is necessary for us to remember their fundamental ideas and to interpret their words and conscious acts in the light of their methods of thought; (4) That in the development of modern organic philosophy new ideas were introduced and new meanings assigned to terms; (5) That from this latter fact, from the inability to agree on fundamental conceptions, arose confusion; (6) That the doctrine of state sovereignty as it has been developed rests on philosophic presuppositions almost if not entirely unknown to the framers of the Constitution; (7) That if we use the terms and insist on the ideas of the organic philosophy, we are entitled to seek the realities lying behind the words of men.

Axdrew McLaughun, Social Compact and Constitutional Construction, in American IIistorical Review, April, 1900. 468-490. 


\section{Chapter XVIII}

\section{WASHINGTON'S FAREWELI ADDRESS}

\section{SUGGESTIONS}

This document was addressed to the People of the United States as a final word of parting from the President. Its date the 17th of September, indicates the day of its publication, but during the previous summer Washington, with the advice of Madison and Hamilton, had been at work upon the address. Its text contains the personal point of view which the Father of Our Country assumed towards the government. It sets forth his policy in domestic and foreign relations; it abounds in wholesome advice in regard to affairs of state; and it is reminiscent of his own share in the building up of a government to the organization and administration of which he had contributed so great a part.

The instruction given in this document to the American people has been followed until the present decade with much faithfulness. In the study of this final declaration we should note the doctrines of the Constitutional Convention, the principles of Washington's administration, and the fear which he felt of a division resulting from sectional partisanship.

In reading the Farewell Address, one is compelled to dwell upon the noble spirit, the unselfish motives, and exalted ideal of its author, whose chief aim had been to bind the separate states together in a lasting union.

For Outlines and Material, see Appendix B.

\section{DOCUMENT}

Washington's Farewell Address to the People of the United States (September 17 th, 1796)

George

Friends, and Fellow-Citizens, The period for Washington. a new election of a Citizen, to administer the Ex$277-325$. ecutive Government of the United States, being not 
far distant, and the time actually arrived, when your thoughts must be employed in designatiug the person, who is to be clothed with that important trust, it appears to me proper, especially as it may conduce to a more distinct expression of the public voice, that I should now apprize you of the resolution $I$ have formed, to decline being considered among the number of those, out of whom a choice is to be made.

I beg you, at the same time, to do me the justice to be assured, that this resolution has not been taken, without a strict regard to all the considerations appertaining to the relation, which binds a dutiful citizen to his country - and that, in withdrawing the tender of service - which silence in my situation might imply, I am influenced by no diminution of zeal for your future interest, no deficiency of grateful respect for your past kindness; but am supported by a full conviction that the step is compatible with both.

The acceptance of, and continuance hitherto in, The "Third the office to which your suffrages have twice called me, have been a uniform sacrifice of inclination to the opinion of duty, and to a deference for what appeared to be your desire. - I constantly hoped, that it would have been much earlier in my power, consistently with motives, which I was not at liberty to disregard, to return to that retirement, from which I had been reluctantly drawn. - The strength of my inclination to do this, previous to the last election, had even led to the preparation of an address to declare it to you; but mature reflection on the then perplexed and critical posture of our affairs with foreign Nations, and the unanimous advice of persons entitled to my confidence, impelled me to abandon the idea. -

I rejoice that the state of your concerns, external as well as internal, no longer renders the pursuit of inclination incompatible with the sentiment of duty,

Term "tradition is emphasized by Washington's determination to retire at the end of the second term. 
Personal modesty was the foundation for Washington's habitual justice to himself and others. or propriety; and am persuaded, whatever partiality may be retained for my services, that, in the present circumstances of our country, you will not disapprove my determination to retire.

The impressions, with which I first undertook the arduous trust, were explained on the proper occasion. In the discharge of this trust, I will only say, that I have, with good intentions, contributed towards the organization and administration of the government, the best exertions of which a very fallible judgment was capable. - Not unconscious, in the outset, of the inferiority of my qualifications, experience in my own eyes, perhaps still more in the eyes of others, has strengthened the motives to diffidence of myself; and every day the increasing weight of years admonishes me more and more, that the shade of retirement is as necessary to me as it will be welcome. - Satisfied, that, if any circumstances have given peculiar value to my services, they were temporary, I have the consolation to believe, that, while choice and prudence invite me to quit the political scene, patriotism does not forbid it.

In looking forward to the moment, which is intended to terminatc the career of my public life, my feelings do not permit me to suspend the deep acknowledgment of that debt of gratitude, which I owe to my beloved country, - for the many honours it has conferred upon me; still more for the steadfast confidence with which it has supported me; and for the opportunities I have thence enjoyed of manifesting my inviolable attachment, by services faithful and persevering, though in usefulness unequal to uny zeal. - If benefits have resulted to our country from these services, let it always be remembered to your praise, and as an instructive example in our annals, that under circumstances in which the Passions, agitated in every direction, were liable to mislead, amidst appearances sometimes dubious, vicissitudes of fortune often discouraging, in situ- 
ations in which not unfrequently want of success has countenanced the spirit of criticism, the constancy of your support was the essential prop of the efforts, and a guarantee of the plans by which they were effected. - Profoundly penetrated with this idea, I shall carry it with me to the grave, as a strong incitement to unceasing vows that Heaven may continue to you the choicest tokens of its beneficence - that your union and brotherly affection may be perpetual - that the free constitution, which is the work of your hands, may be sacredly maintained - that its administration in every department may be stamped with wisdom and virtue - that, in fine, the happiness of the people of these States, under the auspices of liberty, may be made complete, by so careful a preservation and so prudent a use of this blessing as will acquire to them the glory of recommending it to the applause, the affection, and adoption of every nation, which is yet a stranger to it.

Here, perhaps, I ought to stop. - But a solicitude for your welfare, which cannot end but with my life, and the apprehension of danger, natural to that solicitude, urge me on an occasion like the present, to offer to your solemn contemplation, and to recommend to your frequent review, some sentiments; which are the result of much reflection, of no inconsiderable observation, and which appear to me allimportant to the permanency of your felicity as a People. - These will be offered to you with the more freedom, as you can only see in them the disinterested warnings of a parting friend, who can possibly have no personal motive to bias his counsel. - Nor can I forget, as an encouragement to it your indulgent reception of my sentiments on a former and not dissimilar occasion.

Interwoven as is the love of liberty with every Reference ligament of your hearts, no recommendation of mine to inherent is necessary to fortify or confirm the attachment. - love of free- 
Teutonic people.

The Unity of Government which constitutes you one people, is also now dear to you. - It is justly so; - for it is a main Pillar in the Edifice of your real independence; the support of your tranquillity at home; your peace abroad; of your safety; of your prosperity in every shape; of that very Liberty, which you so highly prize. - But as it is easy to foresee, that, from different causes, and from different quarters, much pains will be taken, many artifices employed, to weaken in your minds the conviction of this truth; - as this is the point in your political fortress against which the batteries of internal and external enemies will be most constantly and actively (though often covertly and insidiously) directed, it is of infinite moment, that you should properly estimate the immense valne of your national Union to your collective and individual happiness; - that you should cherish a cordial, habitual, and immorable attachment to it; accustoming yourselves to think and speak of it as of the Palladium of your political safety and prosperity; watching for its preservation with jealous anxiety; discountenancing whatever may suggest even a suspicion that it can in any event be abandoned; and indignantly frowning upon the first dawning of every attempt to alienate any portion of our Country from the rest, or to enfeeble the sacred ties which now link together the various parts.

For this you have every inducement of sympathy and interest. Citizens, by birth or choice, of a common country, that country has a right to concentrate your affections. The name of American, which belongs to you, in your national capacity, must always exalt the just pride of Patriotism, more than any appellation derived from local discriminations. - With slight shades of difference, you have the same Religion, Manners, Hahits, and political Principles. -

1776-1783. You have in a common cause fought and triumphed 
together; the Independence and Liberty you possess are the work of joint counsels, and joint efforts - of common dangers, sufferings, and successes.

But these considerations, however powerfully they address themselves to your sensibility, are greatly outweighed by those, which apply more immediately to your Interest. - Here every portion of our country finds the most commanding motives for carefully guarding and preserving the Union of the whole.

The North, in an unrestrained intercourse with Already the South, protected by the equal Laws of a common the North government, finds in the productions of the latter wasthe comgreat additional resources of maritime and commer- tre, and the cial enterprise - and precious materials of manufac- South the cial enterprise - and precious materials of manufac- great agrituring industry. - The South, in the same inter-cultural course, benefiting by the agency of the North, sees its agriculture grow and its commerce expand. Turning partly into its own cliannels the seamen of the North, it finds its particular navigation iuvigorated; - and, while it contributes, in different ways, to nourish and increase the general mass of the national navigation, it looks forward to the protection of a maritime strength to which itself is unequally adapted. The East, in a like intercourse with the West, already finds, and in the progressive improvement of interior communications, by land and water, will more and more find a valuable vent for the commodities which it brings from abroad, or manufactures at home. - The West derives from the East supplies requisite to its growth and comfort - and, what is perhaps of still greater consequence, it must of necessity owe the secure enjoyment of indispensable outlets for its own productions to the weight, influence, and the future maritime strength of the Atlantic side of the Union, directed by an indissoluble community of interest as one Nation. - Any other The Louisitenure by which the West can hold this essential ana Purchase advantage, whether derived from its own separate in 1803 strength, or from an apostate and unnatural con- the baiance. 
Anti-imperialism. nexion with any foreign Power, must be intrinsically precarious.

While, then, every part of our country thus feels an immediate and particular interest in Union, all the parts combined in the united mass of means and efforts cannot fail to find greater strength, greater resource, proportionably greater security from external danger, a less frequent interruption of their Peace by foreign Nations; and, what is of inestimable value! they must derive from Union an exemption from those broils and wars between themselves, which so frequently afflict neighbouring countries not tied together by the same government; which their own rivalships alone would be sufficient to produce; but which opposite foreign alliances, attachments, and intrigues would stimulate and embitter. - Hence, likewise, they will avoid the necessity of those overgrown Military establishments, which, under any form of government, are inauspicious to liberty, and which are to be regarded as particularly hostile to Republican Liberty. In this sense it is, that your Union ought to be considered as a main prop of your liberty, and that the love of the one ought to endear to you the preservation of the other.

These considerations speak a persuasive language to every reflecting and virtuous mind, - and exhibit the continuance of the Uxion as a primary object of Patriotic desire.-Is there a doubt, whether a common government can embrace so large a sphere? Let experience solve it. - To listen to mere speculation in such a case were criminal. We are anthorized to hope, that a proper organization of the whole, with the auxiliary agency of governments for the respective subdivisions, will afford a happy issue to the experiment. "T is well worth a fair and full experiment. With such powerful and obvious motives to Union, affecting all parts of our country, while experience shall not 
have demonstrated its impracticability, there will always be reason to distrust the patriotism of those, who in any quarter may endeavour to weaken its bands.

In contemplating the causes, which may disturb our Union, it occurs as matter of serious concern, that any ground should have been furnished for characterizing parties by Geographical discrimina- Note, as tions, - Northern and Southern, - Atlantic and Western; whence designing men may endeavour to fication in excite a belief, that there is a real difference of South Carolocal interests and views. One of the expedients lina, 1832, of party to acquire influence, within particular dis- War, 1847, tricts, is to misrepresent the opinions and aims of Civil War, tricts, is to misrepresent the opinions and aims of 1861 , and the other districts. - You cannot shield yourselves too Silver Quesmuch against the jealousies and heartburnings tion, 1895. which spring from these misrepresentations; they tend to render alien to each other those, who ought to be bound together by fraternal affection. - The inhabitants of our Western country have lately had a useful lesson on this head. - They have seen, in the negotiation by the Executive, and in the unanimous ratification by the Senate, of the treaty with Spain, and in the universal satisfaction at that event, throughout the United States, a decisive proof how Treaty and unfounded were the suspicions propagated among Treaty of them of a policy in the General Government and in 1795 settled the Atlantic States unfriendly to their interests in gation of the regard to the Mississippi. - They have been wit- Mississippi, nesses to the formation of two Treaties, that with and gave "a Great Britain, and that with Spain, which secure to posit" withthe could desire, in respect to our in the Spanthein every thing they could desire, in respect to our ish territory, Foreign Relations, towards confirming their pros- free of duty perity. - Will it not be their wisdom to rely for during transthe preservation of these advantages on the UNION by which they were procured? - Will they not henceforth be deaf to those advisers, if such there are, who would sever them from their Brethren, and connect thein with Aliens? - 
To the efficacy and permanency of your Union, a Government for the whole is iudispensable. - No alliances however strict between the parts can be an adequate substitute. - They must inevitably experience the infractious and interuptions, which all alliances in all times have experienced. - Sensible

Belief that the Articles of Confederation were weak, but the Constitution strong.

No secession possible. of this momentous truth, you have improved upon your first essay, by the adoption of a Constitution of Government better calculated than your former for an intimate Union, and for the efficacious management of your common concerns. This government, the offspring of our own choice, uninfluenced and unawed, adopted upon full investigation and mature deliberation, completely free in its principles, in the distribution of its powers, uniting security with energy, and containing within itself a provision for its own amendment, has a just claim to your confidence and your support. - Respect for its authority, compliance with its Laws, acquiescence in its measures, are duties enjoined by the fundanental maxims of true Liberty. - The basis of our political systems is the right of the people to make and to alter their Constitutions of Government. But the Constitution which at any time exists, till changed by an explicit and authentic act of the whole People, is sacredly obligatory upon all. The very idea of the power and the right of the People to establish Government, presupposes the duty of every individual to obey the established Government.

All obstructions to the execution of the Laws, all combinations and associations, under whatever plausible character, with the real design to direct, control, counteract, or awe the regular deliberation and action of the constituted authorities, are destructive of this fundamental principle, and of fatal tendency. - They serve to organize faction, to give it an artificial and extraordinary force - to put in the place of the delegated will of the Nation, the 
will of a party; - often a small but artful and enterprising minority of the community; - and, according to the alternate triumphs of different parties, to make the public administration the mirror of the ill-concerted and incongruous projects of faction, rather than the organ of consistent and wholesome plans digested by common councils, and modified by mutual interests. -

However combinations or associations of the above descriptions may now and then answer popular ends, they are likely, in the course of time and things, to become potent engines, by which cunning, ambitious, and unprincipled men will be enabled to subvert the Power of the People, and to usurp for themselves the reins of Government; destroying afterwards the very engines, which have lifted them to unjust dominion. -

Towards the preservation of your Government, and the permanency of your present happy state, it is requisite, not only that you steadily discountenance irregular oppositions to its acknowledged authority, but also that you resist with care the spirit of inuovation upon its principles, however specious the pretexts. - One method of assault may be to effect, in the forms of the Constitution, alterations, which will impair the energy of the system, and thus to undermine what cannot be directly overthrown. - In all the changes to which you may be Constituinvited, remember that time and habit are at least tional as necessary to fix the true character of Govern- Amendments, as of other human institutions - that experience is the surest standard, by which to test the real tendency of the existing Constitution of a country - that facility in changes, upon the credit of mere hypothesis and opinion, exposes to perpetual change, from the endless variety of hypothesis and opinion : - and remember, especially, that for the efticient management of your common interests, in a country so extensive as ours, a Government of as 
much vigor as is consistent with the perfect security of Liberty is indispensable. Liberty itself will find in such a Government, with powers properly distributed and adjusted, its surest Guardian. - It is, indeed, little else than a name, where the Government is too feeble to withstand the enterprise of faction, to confine each member of the society within the limits prescribed by the laws, and to maintain all in the secure and tranquil enjoyment of the rights of person and property.

I have already intimated to you the danger of Parties in the State, with particular reference to the founding of them on Geographical discriminations. - Let me now take a more comprehensive view, and warn you in the most solemn manker against the baneful effects of the Spirit of Party, generally.

This Spirit, unfortunately, is inseparable from our nature, having its root in the strongest passions of the human mind. - It exists under different shapes in all Governments, more or less stifled, controled, or repressed; but, in those of the popular form, it is seen in its greatest rankness, and is truly their worst enemy. -

The alternate domination of one faction over another, sharpened by the spirit of revenge natural to party dissension, which in different ages and countries has perpetrated the most horrid enormities, is itself a frightful despotism. - But this leads at length to a more formal and permanent despotism. - The disorders and miseries, which result, gradually incline the minds of men to seek security and

"The Man on Horseback." repose in the absolute power of an Individual; and sooner or later the chief of some prevailing faction, more able or more fortunate than his competitors, turns this disposition to the purposes of his own elevation, on the ruins of Public Liberty.

Without looking forward to an extremity of this kind, (which nevertheless ought not to be entirely out of sight), the conmon and continual mischiefs 
of the spirit of Party are sufficient to make it the interest and duty of a wise People to discourage and restrain it. -

It serves always to distract the Public Councils, and enfeeble the Public Administration. - It agitates the community with ill founded jealousies and false alarms, kindles the animosity of one part against another, foments occasionally riot and insurrection. - It opens the doors to foreign influence and corruption, which find a facilitated access to the Government itself through the ehannels of party passions. Thus the policy and the will of one country are subjected to the policy and will of another.

There is an opinion that parties in free countries are useful checks upon the Administration of the Government, and serve to keep alive the Spirit of Liberty. - This within certain limits is probably true; and in Governments of a Monarchical cast, Patriotism may look with indulgence, if not with favour, upon the spirit of party. - But in those of the popular character, in Governments purely elective, it is a spirit not to be encouraged. - From their natural tendency, it is certain there will always be enough of that spirit for every salutary purpose, - and, there being constant danger of excess, the effort ought to be, by force of public opinion, to mitigate and assuage it. - A fire not to be quenched; it demands a uniform vigilance to prevent its bursting into a flame, lest, instead of warming, it should consume.

It is important, likewise, that the habits of thinking in a free country should inspire caution in those intrusted with its administration, to confine themselves within their respective constitutional spheres; avoiding in the exercise of the powers of one department to encroach upon another. - The spirit of encroachment tends to eonsolidate the powers of all the departments in one, and thus to ereate, whatever the form of government, a real despotism. A 
just estimate of that love of power, and proneness to abuse it, which predominates in the human heart, is sufficient to satisfy us of the truth of this position. The necessity of reciprocal checks in the exercise of political power, by dividing and distributing it into different depositories, and constituting each the Guardian of the Public Weal against invasions by the others, has been evinced by experiments ancient and moderu; some of them in our country and under our own eyes. - To preserve them must be as necessary as to institute them. If in the opinion of the People, the distribution or modification of the Constitutional powers be in any particular wrong, let it be corrected by an amendment in the way which the Constitution designates. - But let there be no change by usurpation; for, though this, in one instance, may be the instrument of good, it is the customary weapon by which free governments are destroyed. 'The precedent must always greatly overbalance in permanent evil any partial or transient benefit, which the use can at any time yield. -

Of all the dispositions and habits, which lead to political prosperity, Religion and morality are indispensable supports. - In vain would that man claim the tribute of Patriotism, who should labour to subvert these great Pillars of human happiness, these firmest props of the duties of Men and Citizens. The mere Politician, equally with the pious man, ought to respect and to cherish them. - A volume could not trace all their connexions with private and public felicity. Let it simply be asked, Where is the security for property, for reputation, for life, if the sense of religious obligation desert the Compare oaths, which are the instruments of investigation in the Mormon Courts of Justice? And let us with caution indulge question. Roberts' case in 1900 . the supposition, that morality can be maintained without religion. - Whatever may be conceded to the influence of refined education on minds of pecu- 
liar structure - reason and experience both forbid us to expect, that national morality can prevail in exclusion of religious principle. -

' $\mathrm{T}$ is substantially true, that virtue or morality is a necessary spring of popular government. - The rule, indeed, extends with more or less force to every species of Free Government. - Who, that is a sincere friend to it, can look with indifference upon attempts to shake the foundation of the fabric? -

Promote, then, as an object of primary importance, institutions for the general diffusion of knowledge. In proportion as the structure of a government gives force to public opinion, it is essential that public opinion should be enlightened. -

As a very important source of strength and se-Compare dis curity, cherish public credit. - One method of pre- cussions on curty, cherish public orentit. serving it is, to use it as sparingly as possible : - standard for avoiding occasions of expense by cultivating peace, the public but remembering also that timely disbursements to cially for prepare for danger frequently prevent much greater foreign disbursements to repel it; avoiding likewise the ac- powers. cumulation of debt, not only by shunning occasions of expense, but by vigorous exertions in time of Peace to discharge the debts, which unavoidable wars may have occasioned, not ungenerously throwing upon posterity the burthen, which we ourselves Debt extinought to bear. The execution of these maxims be- guished in longs to your Representatives, but it is necessary that public opinion should coöperate. - To facilitate to them the performance of their duty, it is essential that you should practically bear in mind, that towards the payment of debts there must be Revenue - that to have Revenue there must be taxes - that no taxes can be devised which are not more Taxation or less inconvenient and unpleasant - that the just if propintrinsic embarrassment, inseparable from the se- erly exelection of the proper objects (which is always a pare "Conchoice of difficulties) onght to be a decisive motive firmatio for a candid construction of the conduct of the 1297 . 
Government in making it, and for a spirit of acquiescence in the measures for obtaining revenue, which the public exigencies may at any time dictate. -

Observe good faith and justice towards all $\mathrm{Na}$ tions. Cultivate peace and harmony with all. - Religion and Morality enjoin this conduct; and can it be, that good policy does not equally enjoin it? - It will be worthy of a free, enlightened, and, at no distant period, a great Nation, to give to mankind the magnanimous and too novel example of a People always guided by an exalted justice and benevolence. - Who can doubt that, in the course of time and things, the fruits of such a plan wonld richly repay any temporary advantages, which might be lost by a steady adherence to it? Can it be, that Providence has not connected the permanent felicity of a Nation with its Virtue? The experiment, at least, is recommended by every sentiment which ennobles human nature. Alas! is it rendered impossible by its vices?

In the execution of such a plan, nothing is more essential, than that permanent, inveterate antipathies against particular Nations, and passionate attachments for others, should be excluded; and that, in place of them, just and amicable feelings towards all should be cultivated. The Nation, which indulges towards another an habitual hatred, or an habitual fondness, is in some degree a slave. It is a slave to its animosity or to its affection, either of which is sufficient to lead it astray from its duty and its interest. - Antipathy in one nation against another disposes each more readily to offer insult and injury, to lay hold of slight causes of umbrage, and to be haughty and intractable, when accidental or trifling occasions of dispute occur. Hence frequent collisions, obstinate, envenomed and bloody contests. The Nation, prompted by ill-will and resentment, sometimes impels to War the Government, contrary to the best calculations of policy. - 
The Government sometimes participates in the national propensity, and adopts through passion what reason would reject; - at other times, it makes the animosity of the Nation subservient to projects of hostility instigated by pride, ambition, and other sinister and pernicious motives. - The peace often, sometimes perhaps the Liberty, of Nations has been the victim. -

So likewise, a passionate attachment of one French alliNation for another produces a variety of evils. - ance. Later, Sympathy for the favourite Nation, facilitating the "Democillusion of an imaginary common interest, in cases Genet's influwhere no real common interest exists, and infusing into one the enmities of the other, betrays the former into a participation in the quarrels and wars of the latter, without adequate inducement or justification: It leads also to concessions to the favourite Nation of privileges denied to others, which is apt doubly to injure the Nation making the concessions; by unnecessarily parting with what ought to have been retained; and by exciting jealousy, ill-will, and a disposition to retaliate, in the parties from whom equal privileges are withheld. And it gives to ambitious, corrupted, or deluded citizens, (who devote themselves to the favoured Nation) facility to betray or sacrifice the interests of their own country, without odium, sometimes even with popularity ; gilding, with the appearances of a virtuous sense of obligation, a commendable deference for public opinion, or a laudable zeal for public good, the base of foolish compliances of ambition, corruption, or infatuation. -

As avenues to foreign influence in innumerable Question of ways, such attachments are particularly alarming future "An. to the truly enlightened and independent Patriot. - alliance." How many opportunities do they afford to tamper with domestic factions, to practise the arts of seduction, to mislead public opinion, to influence or awe the public Councils! Such an attachment of 
a small or weak, towards a great and powerful nation, dlooms the former to be the satellite of the latter.

Against the insidious wiles of foreign influence, I conjure you to believe me, fellow-citizens, the jealousy of a free people ought to be constaitly awake; since history and experience prove, that foreign influence is one of the most baneful foes of Republican Government. - But that jealousy, to be useful, must be impartial ; else it becomes the instrument of the very influence to be avoided, instead of a defence against it. - Excessive partiality for one foreign nation, and excessive dislike of another, cause those whom they actuate to see danger only on one side, and serve to veil and even second the arts of influence on the other. - Real Patriots, who may resist the intrigues of the favourite, are liable to become suspected and odious; while its tools and dupes usurp the applause and confidence of the people, to surrender their interests. -

The great rule of conduct for us, in regard to foreign Nations, is, in extending our commercial relations, to have with them as little Political connexion as possible. - So far as we have already formed engagements, let them be fulfilled with perfect good faith. - Here let us stop. -

Europe has a set of primary interests, which to us have none, or a very remote relation. - Hence she must be engaged in frequent controversies, the causes of which are essentially foreign to our concerns. - Hence, therefore, it must be unwise in us to implicate ourselves, by artificial ties in the ordinary vicissitudes of her polities, or the ordinary combinations and collisions of her friendships or enmities.

Germ of Monroe Doctrine.
Our detached and distant situation invites and enables us to pursue a different course. If we remain one People, under an efficient government, the period is not far off, when we may defy matcrial injury from external annoyance; when we may 
take such an attitude as will cause the neutrality, we may at any time resolve upon, to be scrupulously respected; when belligerent nations, under the impossibility of making acquisitions upon us, will not likely hazard the giving us provocation; when we may choose peace or war, as our interest, gnided by justice, shall counsel.

Why forego the advantages of so peculiar a situation? - Why quit our own to stand upon foreign ground? - Why, by interweaving our destiny with that of any part of Europe, entangle our peace and prosperity in the toils of European ambition, rivalship, interest, humour, or caprice?-

It is our true policy to steer clear of permanent alliances with any portion of the foreign world;- so far, I mean, as we are now at liberty to do it; - for let me not be understood as capable of patronizing infidelity to existing engagements. (I hold the maxim no less applicable to public than to private affairs, that honesty is always the best policy.) I repeat it, therefore, let those engagements be observed in their genuine sense. - But, in my opinion, it is unnecessary and would be unwise to extend them. -

Taking care always to keep ourselves, by suitable establishments, on a respectably defensive posture, we may safely trust to temporary alliances for extraordinary emergencies. -

Harmony, liberal intercourse with all nations, are recommended by policy, humanity, and interest. But even our commereial policy should hold an equal and impartial hand; - neither sceking nor granting exclusive favours or preferences; - consulting "Recithe natural course of things ; - diffusing and diversi- procity." fying by gentle means the streams of commerce, but forcing nothing; establishing, - with Powers s disposed, - in order to give trade a stable course, to define the rights of our Merchants, and to enable the government to support them,- conventional rules 
of intercourse, the best that present circumstances and mutual opinion will permit, but temporary, and liable to be from time to time abandoned or varied, as experience and circumstances shall dictate; constantly keeping in view, that it is folly in one nation to look for disin terested favours from another; - that it must pay with a portion of its independence for whatever it may accept under that character ; - that, by such acceptance, it may place itself in the condition of having given equivalents for nominal favours, and yet of being reproached with ingratitude for not giving more. - There can be no greater error than to expect or calculate upon real favours from Nation to Nation. It is an illusion, which experience must cure, which a just pride ought to discard.

His benedictions, politi cal and national.
In offering to you, my Countrymen, these counsels of an old and affectionate friend, I dare not hope they will make the strong and lasting impression I could wish, - that they will control the usual current of the passions, or prevent our Nation from running the course, which has hitherto marked the destiny of nations. - But, if I may even flatter myself, that they may be productive of some partial benefit, some occasional good; that they may now and then recur to moderate the fury of party spirit, to warn against the mischiefs of foreign intrigue, to guard against the impostures of pretended patriotism; this hope will be a full recompense for the solicitude for your welfare, by which they have been dictated. -

How far in the discharge of my official duties, I have been guided by the principles which have been delineated, the public Records and other evidences of my conduct must witness to You and to the world. - To myself, the assurance of my own conscience is, that $I$ have at least believed myself to be guided by them.

In relating to the still subsisting war in Europe, 
my Proclamation of the 22d of April, 1793, is the index to my Plan. - Sanctioned by your approving voice, and by that of your Representatives in both Houses of Congress, the spirit of that measure has continually governed me : - uninfluenced by any attempts to deter or divert me from it.

After deliberate examination, with the aid of the best lights I could obtain, I was well satisfied that our country, under all the circumstances of the case, had a right to take, and was bound in duty and interest to take, a Neutral position. - Having taken it, I determined, as far as should depend upon me, to maintain it, with moderation, perseverance, and firmness. -

The considerations, which respect the right to hold this conduct, it is not necessary on this occasion to detail. I will only observe, that, according to my understanding of the matter, that right, so far from being denied by any of the Belligerent Powers, has been virtually admitted by all. -

The duty of holding a neutral conduct may be inferred, without anything more, from the obligation which justice and humanity impose on every Nation, in cases in which it is free to act, to maintain inviolate the relations of Peace and Amity towards other Nations. -

The inducements of interest for observing that conduct will best be referred to your own reflections and experience. - With me, a predominant motive has been to endeavour to gain time to our country to settle and mature its yet recent institutions, and to progress without interruption to that degree of strength and consistency, which is necessary to give it, humanly speaking, the command of its own fortunes.

Though, in reviewing the incidents of my Administration, I am unconscious of intentional error - I am nevertheless too sensible of my defects not to think it probable that I may have committed many 
errors. - Whatever they may be, I fervently beseech the Almighty to avert or mitigate the evils to which they may tend. - I shall also carry with me the hope, that my Country will never cease to view them with indulgence; and that, after forty-five years of my life dedicated to its service with an upright zeal, the faults of incompetent abilities will be consigned to oblivion, as myself must soon be to the mansions of rest.

Relying on its kindness in this as in other things, and actuated by that fervent love towards it, which is so natural to a man, who views in it the native soil of himself and his progenitors for several generations; - I anticipate with pleasing expectation that retreat, in which I promise myself to realize, without alloy, the sweet enjoyment of partaking, in the midst of my fellow-citizens, the benign influence of good Laws under a free Government, - the ever favourite object of my heart, and the happy reward, as I trust, of our mutual cares, labours, and dangers.

George Washington.

Gazette of the United States, September 17th, 1796.

\section{CONTEMPORARY EXPOSITION}

SEWALL (1799)

His address to the people of America, on his retiring from the cares of government, is one of the most invaluable legacies ever left to a people. It has been celebrated in Europe, and compared to that bequeathed by Moses to the nation of Israel. ... Let this be our oracle; let us read and study it day and night. In the language of inspiration, "Let us bind it about our necks, and engrave it on the tablet of our hearts." In this invaluable gift, among a variety of other excellent precepts, suffer me to remind you of a fer. He most affectionately cantions his countrymen against all immoderate attachments to some, and violent antipathies against other nations. He recommends harmony and liberal intercourse with all, at the same time that he deprecates too close a connection with any. $\mathrm{He}$ 
exhorts to obedience and submission to government, and a generous confidence in our rulers, whom we ourselves have chosen; while he warns against all combinations, whether open or covert, that tend to weaken government, or to lessen the authority of those who administer it. He inculcates the practice of justice, good faith, temperance and economy, with all the moral virtues; and of religion emphatically, as the basis and foundation of them all. He exhorts us to the utmost of our power, to cultivate peace with every nation on earth; and as the surest means to preserve it, strongly urges the necessity of maintaining the best state of defence in our power, both by sea and land. But, above all, he exhorts to union among ourselves between States and among individuals. On this, he assures us, our prosperity, nay, our very existence as a nation depends. Is the counsel good? Let us follow it. Are these admonitions wise? We will obey them. Thus shall we best prove the sincerity of our gratitude to their author, and fully evidence our veneration for his memory. But if we disregard and disobey them, what are we but hypocrites, or self-deceivers? Obedience will lead us to the highest pinnacle of national glory. A contrary conduct will dishonour, though it cannot injure oul greatest benefactor, and end in irremediable ruin. "If we are wise, we shall be wise for ourselves, but if we scorn, we alone shall bear it."

Joxathay Mrtchell Sewald, in Eulogies and Orations on Washington. 35,42 .

\section{PAINE (1800)}

The invaluable valediction, bequeathed to the people, who inherited his affections, is the effort of a mind, whose powers, like those of prophecy, could overleap the tardy progress of human reason, and unfold truth without the labour of investigation. Impressed in indelible characters, this Legacy of His Intelligence will descend, unsullied as its purity, to the wonder and instruction of succeeding generations; and, should the mild philosophy of its maxims be ingrafted into the policy of nations, at no distant period will the departed hero, who now lives only in the spotless splendour of his own great actions, exist in the happiness and dignity of mankind.

Thosras Paine, in Eulogies and Orations on Washington. 65. 


\section{BLYTH (1800)}

Before the expiration of his last presidential term, he gave us his paternal advice, which, if duly attended to, will forever preserve to us the inheritance of freedom. Let us pursue this advice, and never depart from it; it is addressed to us all; it is addressed to every American. "Let the union of the States" said our deceased Washington, "and the reciprocity of interests be the groundwork of your political existence; let the illiberal spirit of party be banished forever from among you; let just and amicable feelings, devoid of all partialities and antipathies, regulate your conduct with all nations; guard against the interference of foreign nations in your internal concerns." In this advice, our Washington still lives; in this bequest of the father of our country, to the whole American people, our Washington will forever live, in the hearts and minds of all patriots over the whole globe; and his venerable name will descend with unfading glory, down the perpetual succession of time, through ages of ages.

Joseph Burth, in Eulogies and Orations on Washington. 211.

MASON (1800)

Having lavished all her honours, his country had nothing more to bestow upon him except her blessing. But he had more to bestow upon his country. His views and his advice, the condensed wisdom of all his reflection, observation and experience, he delivers to his compatriots in a manual worthy of them to study, and of him to compose.

JoHx M. Mason, in Eulogies and Orations on Washington. 239.

MINOT (1800)

The dangers of the Commonwealth having subsided at the close of his second administration, he felt himself justified, after dedicating forty-five years of his valuable life to her service, in withdrawing to receive with resignation the great change of nature, which his age and his toils demonstrated to be near. When he declined your future suffrages, he left you a legacy. What! like Cæsar's to the Romans, money for your sports? Like 
Attalus's, a kingdom for your tyranny? No; he left you not such baubles, nor for such purposes. He left you the records of wisdom for your government; a mirror for the faithful representation to your own view, of yourselves, your weaknesses, your advantages, your dangers: a magnet which points to the secret mines and windings of party spirit, faction, foreign influence : a pillar to the unity of your republic: a band to inclose, conciliate and strengthen the whole of your wonderful and almost boundless communities. Read, preserve the sacred deposit; and lest posterity should forget the truth of its maxims, engrave them on his tomb, that they may read them when they weep before it.

Grorge R. Mrnor, in Eulogies and Orations on Washington. 24.

\section{CRITICAL COMMENT}

SPARKS (1837)

There is not an idea or sentiment in the Farewell Address, which may not be found, more or less extended, in different parts of Washington's writings; nor, after such a perusal, can any one doubt his ability to compose such a paper. As a mere literary performance, though excellent, it is neither extraordinary, nor in any degree superior to many others known to be written by each of the parties. It would add little to the great reputation of Washington, or of Hamilton, if the one or the other could be proved to be its sole and unaided author. It derives its value, and is destined to immortality, and chiefly from the circumstance of its containing wise, pure, and noble sentiments, sanctioned by the name of Washington at the moment when he was retiring from a long public career, in which he had been devoted to the service of his country with a disinterestedness, self-sacrifice, perseverance, and success, commanding the admiration and applause of mankind.

JAREd Sparks, George Washington. XII. 396.

BINNEY (1859)

Washington was undoubtedly the original designer of the Farewell Address; and not merely by general or indefinite in- 
timation, but by the suggestion of perfectly definite subjects, of an end or object, and of a general outline, the same which the paper now exhibits. . . By derivation from himself, the Farewell Address speaks the very mind of Washington. The fundamental thoughts and principles were his; but he was not the composer or writer of the paper. Hamilton was, in the prevalent literary sense, the composer and writer of the paper. . . .

The main trunk was Washington's ; the branches were stimulated by Hamilton; and the foliage, which was not exuberant was altogether his. ...

We might, though not with full and exact propriety, allot the soul to Washington, and the spirit to Hamilton. The elementary body is Washington's, also; but Hamilton has developed and fashioned it, and he has symmetrically formed and arranged the members to give combined and appropriate action to the whole.

Horace Binner, Inquiry into the Formation of Washington's Farewell Address. 171.

\section{OLNEY (1900)}

It has heretofore been considered that anything like an alliance between the United States and an European Power, for any purpose or any time, was something not to be thought of. To give a thing a bad name, however undeservedly, is to do much to discredit it, and there is no doubt that the epithet " entangling" - almost invariably applied - has contributed largely to make "alliance" popularly and politically odious. Yet there may be "alliances" which are not " entangling" but wholly advantageous, and without the French alliance, American independence, if not prevented, might have been long postpoued. It has been a prevalent notion that Washington was inimical to all alliances as such and left on record a solemn warning to his countrymen against them. Yet Washington clearly discriminated between alliances that would entangle and those that would not, and between alliances that were permanent and those that were temporary. Justly construed, Washington's utterances are as wise to-day as when they were made, and are no more applicable to the United States than to 
any other nation. It must be the policy of every State to avoid alliances that entangle, while temporary and limited are better than general and permanent alliances because friends and partners should be chosen in view of actually existing exigencies rather than in reliance upon doubtful forecasts of the uncertain future. Nevertheless, up to this time the theory and practice of the United States have been against all alliances peremptorily.

Richard Olnex, Growth of our Foreign Policy in The Atlantic Monthly, March, 1900. 


\section{Chapter XIX}

\section{THE EXTENT OF FEDERAL POWERS (1819)}

\section{SUGGESTIONS}

THIs report of the famous Supreme Court decision in the McCulloch vs. Maryland Case bears date 1819 . Of the decisions made by the Supreme Court in the early part of the century this is the most typical, as setting forth the construction of the powers of the Federal government by the courts.

The decision has a place among the documents of Anglo-Saxon liberty becanse it shows the American theory of limitations, and the extent of the power of the nation to legislate in questions which include individual rights; and the doctrine here stated has ever since been the foundation of American national government.

The exposition and comments which follow give an opportunity for acquaintance with the opinions of the ablest constitutional expounders.

For Outlines and Material, see Appendix B.

\section{DOCUMENT}

Decision in the Case of M'Culloch vs. the State of Maryland. (1819)

United States Writ of error from the court of appeals of Supreme Maryland.

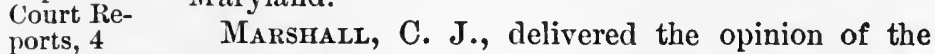
Wheaton, 400 - court.

4:37. The ex- In the case now to be determined, the defendant,
tract is only a small part a sovereign State, denies the obligation of a law of the full enacted by the legislature of the Union; and the opinion. plaintiff, on his part, contests the validity of an Statement of act which has been passed by the legislature of
the issue. that State. The constitution of our country, in its most interesting and vital parts, is to be considered; the conflicting powers of the government of the 
union and of its members, as marked in that constitution, are to be discussed; and an opinion given, which may essentially influence the great operations of the government. No tribunal can approach such a question without a deep sense of its importance, and of the awful responsibility involved in its decision. But it must be decided peacefully, or remain a source of hostile legislation, perhaps of hostility of a still more serious nature; and if it is to be so decided, by this tribunal alone can the decision be made. On the supreme court of the United States has the constitution of our country devolved this important duty. . .

Among the enumerated powers, we do not find The omitted that of establishing a bank or creating a corpora- passage intion. But there is no phrase in the instrument phrase: which, like the articles of confederation, excludes incidental or implied powers; and which requires "This govthat every or inplied powers; and which requires acknowthat everything granted shall be expressly and ledged to be minutely described. Even the 10th amendment, one of enuwhich was framed for the purpose of quieting the powers." excessive jealousies which had been excited, omits the word " expressly," and declares only that the powers " not delegated to the United States, nor See Arts. of prohibited to the States, are reserved to the States or to the people; " thus leaving the question, whether See Conthe particular power which may become the subject stitution, of contest, has been delegated to the one govern- ment $\mathbf{x}$. ment, or prohibited to the other, to depend on a fair construction of the whole instrument. . . .

We admit, as all must admit, that the powers of It would have the government are limited, and that its limits are the Court, not to be trauscended. But we think the sound impossible to constrution of the enumerate national legistare all the national legislature that discretion, with respect to tails, unless the means by which the powcrs it confers are to be the Constitucarried into execution, which will enable that body "partake of to perform the high duties assigned to it, in the the prolixity manner most beneficial to the people. Let the end code." 
Since the government has a right to do an act, it should be allowed to select the means.

Taxation, especially since "Confirmatio Chartarum," has been a right of the people.

be legitimate, let it be within the scope of the constitution, and all means which are appropriate, which are plainly adapted to that end, which are not prohibited, but consist with the letter and spirit of the constitution, are constitutional. . . .

. . In the Legislature of the Union alone, are all represented. The legislature of the Union alone, therefore, can be trusted by the people with the power of controlling measures which concern all, in the confidence that it will not be abused. This, then, is not a case of confidence, and we must consider it as it really is.

If we apply the principle for which the state of Maryland contends, to the constitution generally, we shall find it eapable of changing totally the character of that instrument. We shall find it capable of arresting all the measures of the government, and of prostrating it at the foot of the States. 'The American people have declared their constitution, and the laws made in pursuance thereof, to be supreme; but this principle would transfer the supremacy, in fact, to the States.

If the States may tax one instrument, employed

In both Arts. of Confed., vi., and the Constitution, U. S., Art. i. Sect. 10, the powers denied to the several States are clearly enumerated.

by the government in the execution of its powers, they may tax any and every instrument. They may tax the mail; they may tax the mint; they may tax patent rights; they may tax the papers of the custom-house; they may tax judicial process ; they may tax all the means employed by the government, to an excess which would defeat all the ends of government. This was not intended by the American people. They did not design to make their government dependent on the States.

Gentlemen say, they do not claim the right to extend state taxation to these objects. They limit their pretensions to property. But on what prineiple is this clistinetion made? Those who make it have furnished no reason for it, and the principle for which they contend denies it. They contend 
that the power of taxation has no other limit than is found in the 10th section of the 1st article of the constitution; that, with respect to everything else, the power of the States is supreme, and admits of no control. If this be true, the distinction between property and other subjects to which the power of taxation is applicable, is merely arbitrary, and can never be sustained. This is not all. If the controlling power of the States be estab- State sovlished; if their supremacy as to taxation be ac- ereignty had knowledred. what is to restrain their exercising been the warknowledged; what is to restrain their exercising cry of the this control in any shape they may please to give Jeffersonian it? Their sovereionty is not confined to taxation Republican it? Their sovereignty is not confined to taxation. party at That is not the only mode in which it might be dis- the outset. played. The question is, in truth, a question of supremacy; and if the right of the States to tax the means employed by the general government be conceded, the declaration that the constitution, and the laws made in pursuance thereof, shall be the Note the supreme law of the land, is empty and unmeaning Nullification declamation....

The court has bestowed on this subject its most deliberate consideration. The result is a conviction that the States have no power, by taxation or otherwise, to retard, impede, burden, or in any manner control, the operations of the constitutional laws enacted by Congress to carry into execution the powers rested in the general government. This is, we think, the unavoidable consequence of that supremacy which the constitution has declared.

We are unanimously of opinion, that the law passed by the legislature of Maryland, imposing a tax on the Bank of the United States, is unconstitutional and roid.

This opinion does not deprive the States of any resources which they originally possessed. It does not extend to a tax paid by the real property of sion, but the bank, in common with the other real property they are within the State, nor to a tax imposed on the in- extent.

Actual state rights are not limited or infringed upon, in this deci- 
terests which the citizens of Maryland may hold in this institution, in common with other property of the same description throughout the State. But this is a tax on the operations of the bank, and is, consequently, a tax on the operation of an instrument employed by the government of the Union to carry its powers into execution. Such a tax must be unconstitutional.

Not the first ... On consideration whereof, it is the opinion instance of of this court, that the act of the legislature of quashing a state law by Federal Courts.

Maryland is contrary to the Constitution of the United States, and roid. . . . It is therefore adjudged and ordered, that the said judgment of the said court of appeals of the State of Maryland, in this case, be, and the same hereby is, reversed and annulled. And this court, proceeding to render such judgment as the said court of appeals should have rendered, it is further adjudged and ordered, that the judgment of the said Baltimore county court be reversed and annulled, and that judgment be entered in the said Baltimore county court for the said James W. M'Culloch.

\section{CONTEMPORARY EXPOSITION}

NHEE' REGISTER (1819)

Having so long entertained such opinions as incontrovertible truths, and as a weak, but honest apostle in the cause of mankind, endeavoured to impress them upon all within our reach, the horror of an apprehension that we have deceived ourselves and others, may be better felt than described: it is like to a man discovering the infidelity of his wife whilst she reposes on his bosom, and heart seems united to heart! A deadly blow has been struck at the sovereignty of the states, and from a quarter so far removed from the people as to be hardly accessible to public opinion - it is needless to say that we allude to the decision of the supreme court, in the case of McCulloch versus the State of Maryland, by which it is estab- 
lished that the states cannot tax the bank of the United States....

But we believe that the broad question is settled, for the National Intelligencer of Monday last, giving an account of the proceedings of the supreme court on Saturday, says - "Mr. chief justice Marshall delivered the unanimous opinion of the court in the case of McCulloch against the state of Maryland.

"1st. That congress liad, constitutionally, a right to establish the banks of the United States.

"2dly. That the bank has authority to establish branches in such states of the Union as it thinks fit.

"3dly. That the state of Maryland has no right to tax the branch of the bank established in that state."

We are awfully impressed with a conviction that the welfare of the union has received a more dangerous wound than fifty Hartford conventions, hateful as that assemblage was, could inflict - reaching so close to the vitals as seemingly to draw the heart's blood of liberty and safety, and which may be wielded to destroy the whole revenues, and so do away the sovereignties of the states. In the progress of this principle, we can easily anticipate the time when some daring scoundrel, having fortified himself by soul-trading incorporations, may seize upon these fair countries for a kingdom, and, surrounded with obedient judges and lying priests, punish his opponents, after the manner of European despots, with fines, imprisonment and tortures here, and the terrors of the lower world hereafter. But we will not despair of the republic, nor yet give up the ship; no alternative, however, is left to preserve the sovereignty of the states but by amending the constitution of the United States, and more clearly defining the original intentions of that instrument in several respects, but especially in regard to incorporations: - these are evideuces of sovereignty; congress has not a sovereign power, except in the cases specially delegated.

Hezexian NiLes, in Niles" “Weekly Register." XVI. 43.

FREEMAN'S JOURNAL (1819)

"The book!" Something is still said in Philadelphia about the book found in the office of the Bank of the United States 
at Baltimore. It is probable, that the eminent appellation of this thing will be lost, by finding three or four similar books at other places! We have good reason to believe that attempts have been made to rival Baltimore in - speculation! . . .

"City Bank of Baltimore." The board of directors elected since the "blow up" of this bank, have, at length, appointed a day for laying a statement of the affairs of the institution before the stockholders - viz., the 20th of October next. This distant date, after so long a delay, has excited no little surprise; but we are told by those we have a right to believe, that the books and accounts of this bank were in such a state of confusion, that an earlier period could not be fixed upon, though the new cashier and clerks, (well skilled in accounts) had laboured and were yet labouring excessively, to ascertain the true state of the bank! ! !

The stock of this bank is quoted by the brokers at $\$ 7$ for 15 paid. . . .

"Bad Times!" Honesty has fled from the world, and Sincerity is fallen asleep - Piety has hidden herself, and Justice cannot find the way - the Helper is not at home, and Charity lies sick; Benevolence is under arrest, and Faith is nearly extinguished; the Virtues go a begging, and Truth has long since been buried; Credit has turned crazy, and Conscience is nailed on the wall.

Quoted in Niles' "Weekly Register." XVI. 421.

\section{CRITICAL COMMENT}

STORY (1833)

It is true that among the enumerated powers we do not find that of establishing a bank, or creating a corporation. But we do find there the great powers to levy and collect taxes: to borrow money : to regulate commerce : to declare and conduet war: and to raise and support armies and navies. Now, if a bank be a fit means to execute any or all of these powers, it is just as much implied, as any other means. . . . In the present times it call hardly require argument to prove that it is a convenient, a useful and an essential instrument in the fiscal operations of the government of the United States. This is so. 
generally admitted by sound and intelligent statesmen that it would be a waste of time to endeavour to establish the truth by an elaborate survey of the mode in which it touches the administration of all the various branches of the powers of the Government.

Josepr Story, Commentaries on the Constitution of the United States. 448.

\section{HARE (1889)}

The case of McCulloch $v$. The State of Maryland is entirely consonant with the course of judicial decision, and so much in harmony with that of legislature that if the doctrine which it established were overthrown a large and essential part of the legislation of Congress would fall with it. That the Bank of the United States was twice incorporated by men belonging to different parties, and viewing the Constitution in different aspects; that its constitutionality was never assailed successfully, and was sustained on the only occasion when the question was brought into court; that it finally fell, not in consequence of a denial of the implied power of Congress to incorporate a bank, . . . but because the president thought that some of the details of the bill presented for his signature were objectionable and exceeded the limits of the executive power - would be enough to prove, if proof were needed, that the principles vindicated by Chief-Justice Marshall are deeply rooted in the Constitution, and cannot be disturbed without destroying its usefulness.

Johr Insess C. Hare, American Constitutional Law. I. 107.

WILLOUGHBY (1890)

The case of McCulloch $v$. Maryland arose from the attempt on the part of Maryland to prevent the operation, within her borders, of the federal institution, the Second United States Bank. This she endeavoured to do by taxing ont of existence the branch bank which had been located on her territory.

Westel W. Willovghir, Supreme Court of the United Stutes. 59.

W. G. SUMNER (1896)

February 11th, 1818, Maryland laid a stamp tax on notes of any bank doing business in the State and not by or with the 
authority of the same. . . The Bank of the United States paid no heed to this law. In the case at law which resulted (McCulloch $v$. Maryland), the tax was held to be unconstitutional by the Supreme Court of the United States. It was held that the Bauk was constitutionally endowed with a right to establish branches in any State. These branches were not taxable by the State, but real estate, owned by the Bank, or the proprietary interest of citizens of the State in it, might be taxed like other property: Congress has power to charter a national bank as one means of carrying on the fiscal operation of the national government; the States cannot by taxation impede Congress in the exercise of any of its constitutional powers; if the end is legitimate and within the scope of the constitution, any means may be employed which are appropriate and not prohibited. I. 100.

William Graham Sumner, History of Banking in the United States. 


\section{Chapter XX}

\section{LIBERTIES OF OTHER AMERICAN PEOPLES (1823)}

\section{SUGGESTIONS}

TuIs document contains such portions of President Monroe's Message to Congress, Dec. 2, 1823, as bore upon the subject of international relationship. The President called the attention of Congress to the aggressive schemes of Russia, and the probable policy of the Holy Alliance. This memorable doctrine bears the name of the President, because of its place in his annual message; but the principles set forth therein are the embodiment of the thought of great American statesmen from the beginning of the nation. The spirit of "hands off," no "entangling alliances" and "remote situation" can be traced throughout the writings and speeches of such diplomatists as Pownall, Jefferson, Washington, Adains, and John Quincy Adams. The writers upon foreign relationships since 1823 have examined the tenets of this document with great interest. Its power and influence have guided European as well as American thought.

Before presenting the subject of the Monroe Doctrine to students, a certain amount of European history must be reviewed so that an intelligent understanding may be had of the bases of the principles set forth ; Napoleon's aggrandizement, the fall of the great master of the French empire, the restoration of Louis XVIII. to the throne of France; Spain's colonies and their growing spirit of independence; Russia's aggression on the Pacific slope; the Holy Alliance with its conservative belief in monarchical government; the attitude of Great Britain towards the alliance and hence towards the United States, some kuowledge of these questions is absolutely necessary before the document can be appreciated, and before the contemporaneous exposition can illuminate its text.

For Outlines and Material, see Appendix B.

\section{DOCUMENT}

\section{The Monroe Doctrine (1823)}

Embodied in President Monroe's Message at tine J. D. RichCommexcement of the First Session of the ardson: ComEightenth Congress, December 2, 1823. Messages and At the proposal of the Russian Imperial Govern- Papers of the ment, made through the minister of the Emperor II. 209, 219. 
residing here, a full power and instructions have been transmitted to the minister of the United States at St. Petersburg to arrange by amicable negotiation the respective rights and interests of the two nations on the northwest coast of this con-

The dispute as to territory in the northwest was settled by a separate convention between the United

States and

Russia, signed at St. Petersburg, April 5-17, 1824.

This principle declares that no new European colonial establishments shall be allowed on territory hitherto unoccupied.

See Washington's Farewell Address.

Since 1823 there have been no extensions of European political systinent. . . In the discussions to which this interest has given rise and in the arrangements by which they may terminate, the occasion has been judged proper for asserting, as a principle in which the rights and interests of the United States are involved, that the American continents, by the free and independent condition which they have assumed and maintain, are henceforth not to be considered as subjects for future colouization by any European powers. . . . The citizens of the United States cherish sentiments the most friendly in favour of the liberty and happiness of their fellow-men on that side of the Atlantic. In the wars of the European powers in matters relating to themselves we have never taken any part, nor does it comport with our policy so to do. It is only when our rights are invaded or seriously menaced that we resent injuries or make preparation for our defense. With the movements in this hemisphere we are of necessity more immediately connected, and by causes which must be obvious to all enlightened and impartial observers. The political system of the allied powers is essentially different in this respect from that of America. This difference proceeds from that which exists in their respective Governments ; and to the defense of our own, which has been achieved by the loss of so much blood and treasure, and matured by the wisdom of their most enlightened citizens, and under which we have enjoyed unexampled felicity, this whole nation is devoted. We owe it, therefore, to candour and to the amicable relations existing between the United States and those powers to declare that we should consider any attempt on their part to extend their system to any porticn of this hemisphere as 
dangerous to our peace and safety. With the exist- tems to any ing colonies or dependencies of any European power portion of we have not interfered and shall not interfere. But sphere exwith the Governments who have declared their in- cept the dependence and maintained it, and whose indepen- vasion of dence we have, on great consideration and on just Mexico, principles, acknowledged, we conld not view any interposition for the purpose of oppressing them, or controlling in any other manner their destiny, by any European power in any other light than as the manifestation of an unfriendly disposition towards the United States. . . .

Our policy in regard to Europe, which was adopted at an early stage of the wars which have so long $\begin{gathered}\text { Policy of } \\ \text { non-inter- }\end{gathered}$ agitated that quarter of the globe, nevertheless re- vention in mains the same, which is, not to interfere in the European internal concerns of any of its powers; to consider the government de facto as the legitimate government for us ; to cultivate friendly relations with it, and to preserve those relations by a frank, firm, and manly policy, meeting in all instances the just claims of every power, submitting to injuries from none. But in regard to those continents circumstances are eminently and conspicuously different. It is impossible that the allied powers should extend No European their political system to any portion of either con- in the affairs tinent without endangering our peace and happiness; ish-American nor can anyone believe that our southern brethren, Republics. if left to themselves, would adopt it of their own accord. It is equally impossible, therefore, that we should behold such interposition in any form, with indifference.

\section{CONTEMPORARY EXPOSITION} JOHN QUINCY ADAMS (1823)

15th (1823). I received a note from Mr. D. Brent, saying that the President wished to see me at the oflice at noon. I went and found him there. He asked for the correspondence 
relating to the intercourse with the British American colonies, with a view to the particular notice which he intends to take of it in the message; which I thought should have been only in general terms. He also showed me two letters which he had received - one from Mr. Jefferson, 23d October, and one from Mr. Madison of 30th October, giving their opinions on the proposals of Mr. Canning. 'The President had sent them the two dispatches from R. Rush of 23d and 28th August, enclosing the correspondence between Canning and him, and requested their opinions on the proposals. Mr. Jefferson thinks them more important than anything that has happened since our Revolution. He is for acceding to the proposals, with a view to pledging Great Britain against the Holy Allies; though be thinks the island of Cuba would be a valuable and important acquisition to our Union. Mr. Madison's opinions are less decisively pronounced, and he thinks, as I do, that this movement on the part of Great Britain is impelled more by her interest than by a principle of general liberty. . . .

21st. I mentioned also my wish to prepare a paper to be delivered confidentially to Baron Tuyl, and the substance of which I would in the first instance express to him in a verbal conference. It would refer to the verbal eommunications recently made by him, and to the sentiments and dispositions manifested in the extract of a dispatch relating to Spanish affairs which he lately put into my hands. My purpose would be in a moderate and conciliatory manner, but with a firm and determined spirit, to declare our dissent from the principles avowed in those communications; to assert those upon which our own Government is founded, and, while disclaiming all intention of attempting to propagate them by force, and all interference with the political affairs of Europe, to declare our expectation and hope that the European powers will equally abstain from the attempt to spread their principles in the American hemisphere, or to subjugate by force any part of these continents to their will. . . .

4th. I went to the President's and found Gales, the half-editor of the National Intelligencer, there. He said the message was called a war message; and spoke of newspaper paragraphs from Europe announcing that an army of twelve thousand 
Spaniards was to embark immediately to subdue South America. I told him there was absurdity on the face of these paragraphs, as the same newspapers announced with more authenticity the disbanding of the Spanish army. The President himself is singularly disturbed with these rumours of invasion by the Holy Alliance.

C. F. Adays, editor, Memoirs of John Quincy Adams. VI. 185, 194, 226.

JEFFERSON (1823)

To the President

Mónticello, October 24, 1823.

DeAR SIR, - The question presented by the letters you have sent me, is the most momentous which has ever been offered to my contemplation since that of Independence. That made us a nation, this sets our compass and points the course which we are to steer through the ocean of time opening on us. Aud never could we embark on it under circumstances more auspicious. Our first and fundamental maxim should be, never to entangle ourselves in the broils of Europe. Our second, never to suffer Europe to intermeddle with cis-Atlantic affairs. America, North and South, has a set of interests distinct from those of Europe, and peculiarly her own. She should therefore have a system of her own, separate and apart from that of Europe. While the last is labouring to become the domicil of despotism, our endeavour should surely be, to make our hemisphere that of freedom. One nation, most of all, could disturb us in this pursuit; she now offers to lead, aid, and accompany us in it. By acceding to her proposition, we detach her from the bands, bring her mighty weight into the scale of free goverument, and emancipate a continent at one stroke, which might otherwise linger long in doubt and difficulty. Great Britain is the nation which can do us the most harm of any one, of all on earth; and with her on our side we need not fear the whole world. With her then, we should most sedulously cherish a cordial friendship; and nothing would tend more to knit our affections than to be fighting once more, side by side, in the same cause. Not that I would purchase even her amity at the price of taking part in her wars. But the war in which 
the present proposition might engage us, should that be its consequence, is not her war, but ours. Its object is to introduce and establish the American system, of keeping out of our land all foreign powers, of never permitting those of Europe to intermeddle with the affairs of our nations. It is to maintain our own principle, not to depart from it. . . .

I have been so long weaned from political subjects, and have so long ceased to take any interest in them, that I am sensible I am not qualified to offer opinions on them worthy of any attention. But the question now proposed involves consequences so lasting, and effects so decisive of our future destinies, as to rekindle all the interest $I$ have heretofore felt on such occasions, and to induce me to the hazard of opinions, which will prove only my wish to contribute still my mite towards anything which may be useful to our country. And praying you to accept it at only what it is worth, I add the assurance of my constant and affectionate friendship and respect.

Thomas Jefferson, Complete Works. VII. 315, 317.

MADISON (1823)

\section{To President Monroe}

Oct. $30,1823$.

$\mathrm{D}^{\mathrm{R}} \mathrm{S}$ IR, - I have just received from Mr. Jefferson your letter to him, with the correspondence between Mr. Canning and Mr. Rush, sent for his and my perusal, and our opinions on the subject of it. . . The professions we have made to these neighbours, our sympathies with their liberties and independence, the deep interest we have in the most friendly relations with them, and the consequences threatened by a command of their resources by the Great Powers, confederated against the rights and reforms of which we have given so conspicuous and persuasive an example, all unite in calling for our efforts to defeat the meditated crusade.

\section{To Richard Rush}

Montpelier, Nov. 13, 1823.

$\mathrm{D}^{\mathrm{R}} \mathrm{SrR},-\mathrm{I}$ have received your favour of September 10. ... Whatever may be the motives or the management of the British Government, I cannot pause on the question whether 
we ought to join her in defeating the efforts of the Holy Alliance to restore our Independent neighbours to the condition of Spanish Provinces. Our principles and our sympathies; the stand we have taken in their behalf; the deep interest we have in friendly relations with them; and even our security against the Great Powers, who, having conspired against national rights and reforms, must point their most envenomed wrath against the United States, who have given the most formidable example of them; all concur in enjoining on us a prompt acceptance of the invitation to a communion of counsels, and, if necessary, of arms, in so righteous and glorious a cause.

JAMES MADIsON, Works. III. 339, 345.

WEBSTER (1826)

Now, Sir, it did so happen, that, as soon as the Spanish king was completely reëstablished, he invited the coöperation of his allies, in regard to South America. In the same month of December, of 1823, a formal invitation was addressed by Spain to the courts of St. Petersburg, Vienna, Berlin, and Paris, proposing to establish a conference at Paris, in order that the plenipotentiaries there assembled might aid Spain in adjusting the affairs of her revolted provinces. ...

The proposed meeting, however, did not take place. England had already taken a decided course; for as early as October, Mr. Canning, in a conference with the French minister in London, informed him distinctly and expressly, that England would consider any foreign interference, by force or by menace, in the dispute between Spain and the colonies, as a motive for recognizing the latter without delay. It is probable this determination of the English government was known here at the commencement of the session of Congress; and it was under these circumstances, it was in this crisis, that Mr. Monroe's declaration was made. It was not then ascertained whether a meeting of the allies would or would not take place, to concert with Spain the means of reëstablishing her power; but it was plain enough they would be pressed by Spain to aid her operations; and it was plain enough, also, that they had no particular liking to what was taking place on this side of the Atlantic, nor any great disinclination to interfere. This was the posture of affairs; and, Sir, I concur entirely in the senti- 
ment expressed in the resolution of a gentleman from Pennsylvania, that this declaration of Mr. Monroe was wise, seasonable, and patriotic.

It has been said, in the course of this debate, to have been a loose and vague declaration. It was, I believe, sufficiently studied. I have understood, from good authority, that it was considered, weighed, and distinctly and decidedly approved, by every one of the President's advisers at that time. Our government could not adopt on that occasion precisely the course which England had taken. England threatened the immediate recognition of the provinces, if the Allies should take part with Spain against them. We had already recognized them. It remained, therefore, only for our government to say how we should consider a combination of the Allied Powers, to effect objects in America, as affecting ourselves; and the message was intended to say, what it does say, that we should regard such combination as dangerous to us. Sir, I agree with those who maintain the proposition, and I contend against those who deny it, that the message did mean something; that it meant much; and I maintain, against both, that the declaration effected much good, answered the end designed by it, did great honour to the foresight and the spirit of the government, and that it cannot now be taken back, retracted, or annulled, without disgrace. It met, Sir, with the entire concurrence and the hearty approbation of the country. The tone which it uttered found a corresponding response in the breasts of the free people of the United States. That people saw, and they rejoiced to see, that, on a fit occasion, our weight had been thrown into the right scale, and that, without departing from our duty, we had done something useful, and something effectual, for the cause of civil liberty. One general glow of exultation, one universal feeling of the gratified love of liberty, one conscious and proud perception of the consideration which the country possessed, and of the respect and honour which belonged to it, pervaded all bosoms. Possibly the public enthusiasm went too far; it certainly did go far. But, Sir, the sentiment which this declaration inspired was not confined to ourselves. Its force was felt everywhere, by all those who could understand its object and foresee its effect.

Da iniel Webster, Works. III. 202, 203. 


\section{CRITICAL COMMENT}

\section{DANA (1866)}

It is to be borne in mind that the Declarations known as the Monroe Doctrine have never received the sanction of an act or resolution of Congress: nor have they any of that authority which European governments attach to a royal ordinance. 'They are, in fact, only the declarations of an existing administration of what its own policy would be, and what it thinks should ever be the policy of the country, on a subject of paramount and permanent interest. . . .

Confining itself to a declaration against interposition to oppress or control, or to extend the system of the Holy Alliance to this hemisphere, the message avoids committing the government on the subject of acquisition, either by the United States or the European powers, and whether by voluntary cession or conquest. . . . In further explanation of the Monroe Doctrine it is to be noticed that it is correctly called a cloctrine and no more. There is no intimation what the United States will do in case of European interposition, or what means it will take to prevent it. . . . And public opinion may be considered as settled on the point that the action of the nation, in any case that may arise, must be unembarrassed by pledge or compact: and, further, as equally settled, against the introduction of anything approaching the nature of a Holy Alliance for this continent, though it be in the interests of republican institutions.

Richard Henry Dana, Wheaton's Elements of International Law. 109111.

\section{VON HOLST (1875)}

In August, 1823, Rush learned from Canning that the Holy Alliance was beginning to seriously think of interfering in colonial affairs in favour of Spain. England's position on the question had meanwhile substantially changed. If Castlereagh had been willing in 1818 to make the return of the colonies under Spanish dominion the basis of the attempt at intervention, Wellington had by this time used very different language at the congress of Verona, and now Canning declared himself ready to act in direct opposition to the plans of the Holy Alli- 
ance, provided he were assured of the co-operation of the United States. Rush at once forwarded these statements of Canning to his government, which receired them with "great satisfaction," for, as Calhoun, the thell secretary of war, afterwards declared, the power of the Alliance was so great that the United States themselves had not folt safe from its intermeddling. Monroe sent the records conceruing the matter to all the members of his cabinet, and at the same time asked Jefferson for his opinion. The latter answered that "America, North and South," as a result of its own peculiar interests, should also have a peculiar political system, founded on freedom. It should be a leading principle of the United States "never to suffer Europe to intermeddle with cis-Atlantic affairs." For the attainment of these ends the offered help of England should be accepted, even at the risk of a war. The cabinet, after long and careful consideration, came to the same opinion. Almost at the very moment when Spain formally invited the allied powers to a conference in Paris, the president announced in his annual message of Dec. 1, 1823, the so-called Monroe doctrine.

Hermann E. von Holst, The Constitutional History of the United States. $419,420$.

\section{MORSE (1882)}

The doctrine which has been christened with the name of President Monroe, seems likely to win for him the permanent glory of having originated the wise policy which that familiar phrase now signifies. . . . Not only is the "Monroe Doctrine" as that phrase is customarily construed in our day, much more comprehensive than the simple theory first expressed by Monroe and now included in the modern doctrine as a part in the whole, but a principle more fully identical with the imperial one of to-day had been conceived and shaped by Mr. Adams before the delivery of Monroe's famous message. . . . When diseussion arose with Russia concerning her possessions on the northwest coast of this continent, Mr. Adams audaciously told the Russian minister, Baron Tuyl, July 17, 1823, " that we should contest the rights of Russia to any territorial establishment on this continent, and that we should assume distinctly the prin- 
ciple that the American continents are no longer subjects for any new European colonial establishments." "This," says Mr. Charles Francis Adams in a foot-note to the passage in the Diary, " is the first hint of the policy so well known afterwards as the Monroe Doctrine." . . . In a word, Mr. Adams, by his language and actions, established and developed precisely that doctrine which has since been adopted by this country nnder the doubly incorrect name of the "Monroe Doctrine," - a name doubly incorrect, because even the real "Monroe Doctrine" was not an original idea of Mr. Monroe, and because the doctrine which now goes by that name is not identical with the doctrine which Monroe did once declare. Mr. Adams's principle was simply that the United States would take no part whatsoever in foreign politics, not even in those of South America, save in the extreme event, eliminated from among things possible in this generation, of such an interference as was contemplated by the Holy Alliance; and that, on the other hand, she would permit no European power to gain any new foothold upon this continent. Time and experience have not enabled us to improve upon the principles which Mr. Adams worked out for us.

John T. MoRse, JR., John Quincy Adams. 130-137.

\section{C. GILMAN (1883)}

It appears to me probable that Monroe had but little conception of the lasting effect which his words would produce. He spoke what he believed and what he knew that others believed; he spoke under provocation, and aware that his views might be controverted; he spoke with authority after consultation with his cabinet, and his words were timely; but I do not suppose that he regarder this announcement as his own. Indeed, if it had been his own decree or ukase it would have been resented at home quite as vigorously as it would have been opposed abroad. It was because he pronounced not only the opinion then prevalent, but a tradition of other days which had been gradually expanded, and to which the country was wonted, that his words carried with them the sanction of public law. A careful examination of the writings of the earlier statesmen of the Republic will illustrate the growth of the Monroc doctrine as an idea dimly entertained at first, but steadily developed by 
the course of public events and the reflection of those in public life. I have not made a thorough search, but some indications of the mode in which the doctrine was evolved have come under my eye which may hereafter be added to by a more persistent investigator.

The idea of independence from foreign sovereignty was at the beginning of our national life. The term "continental" applied to the army, the congress, the currency, had made familiar the notion of continental independence. This kept in mind the notion of a continental domain. Moreover, in the writings, both public and private, of the fathers of the Republic, we see how clearly they recognized the value of separation from European politics, and of repelling, as far as possible, European interference with American interests.

Daniel C. Gilmax, James Montoe. 161-162.

SCHOULER (1885)

This doctrine, so profound of import, was not, we apprehend, the sudden creation of individual thought, but the result rather of slow processes in our public mind, which had been constantly intent upon problems of self-government, and intensely observant of our continental surroundings; though carried forward, no doubt, like other ideas in the colonial epoch, by the energy and clearer conviction of statesmen who could foresee and link conceptions into a logical chain. Neutrality as to European affairs, freedom from all entangling alliances with the old world, was the legacy of experience which Washington bequeathed to his successors. This might have seemed at first to discourage all external inflnence, and remit our Union to the selfish and isolated pursuit of its own interests. But the annexation of Louisiana proved that the Union itself was destined to expand over an uncertain area of this continent. And, when, inspired by our example, the Spanish colonies of the American continent were seen one after another to shake off the yoke of the parent country, and spontaneously assert their independence, the philanthropic leaders - and none among them so quickly or so persistently as Jefferson - began to predict the fraternal cooperation in the future of these free republics, all modelled alike, in a common scheme for self-preservation which should 
shut out Europe, its rulers and its systems of monarchy forever from this hemisphere; for by such means only could the germ of self-government expand, and the luxuriant growth of this hardy plant make it impossible that the monarchical idea should ever strike a deep root in American soil. ... When liberty struggled in America we were not - we could not be - neutral. The time of announcement and the choice of expression, nevertheless, awaited events. ... It was the courage of a great people personified in a firm chief magistrate that put the fire into those few momentous though moderate sentences, and made them glow like the writing at Belshazzar's feast. . . .

JAMES Schouler, History of the United States. III. 289-290.

TUCKER (1885)

The argument that the Monroe Doctrine can have no validity beeause it has never received legislative sanction, carries with it no weight. Many rules of international law impose an obligation derived from usage alone. The original declaration of Mr. Monroe is a precedent acknowledged by the American people, and to a certain extent acquiesced in by European authorities. Hardly a President since Mr. Monroe has omitted to refer to it in langnage of approval. It has always been regarded as a question independent of party politics, save perhaps in its applieation to the Congress at Panama. It has been persistently asserted by the majority of American statesmen; and to declare that it cannot obtain as a universal obligation is practically to throw discredit upon Washington's farewell address, whose recommendations, though never embodied in statutes or approred by resolution of Congress, have frequently shaped the foreign and domestic policy of the government. . . . Finally, the Monroe Doctrine is to America what the Balanee of Power is to Europe. The analogy may not be complete, because several nations in Furope unite to preserve a ratio of power, while on this hemisphere the influence of the United States is paramount. But it is this feature which is especially worthy of note.

George F. Tucker, The Monroe Doctrine. 130-131. 


\section{PRESIDENT CLEVELAND (1895)}

Without attempting extended argument in reply to these positions it may not be amiss to suggest that the doctrine upon which we stand is strong and sound because its enforcement is important to our peace and safety as a nation, and is essential to the integrity of our free institutions and the tranquil maintenance of our distinctive form of government. It was intended to apply to every stage of our national life, and cannot become obsolete while our Republic endures. If the balance of power is justly a cause for jealous anxiety among the governments of the old world, and a subject for our absolute non-interference, none the less is an observance of the Monroe Doctrine of vital concern to our people and their Government.

Assuming, therefore, that we may properly insist upon this doctrine without regard to "the state of things in which we live," or any changed conditions here or elsewhere, it is not apparent why its application may not be invoked in the present controversy.

If a European power, by an extension of its boundaries, takes possession of the territory of one of our neighbouring Republics against its will and in derogation of its rights, it is difficult to see why to that extent such European power does not thereby attempt to extend its system of government to that portion of this continent which is thus taken. This is the precise action which President Monroe declared to be "dangerous to our peace and safety," and it can make no difference whether the European system is extended by an advance of frontier or otherwise.

... The Monroe doctrine finds its recognition in those principles of international law which are based upon the theory that every nation shall have its rights protected and its just claims enforced.

Grover Cleveland, Special Message, Dec. 17, 1895.

OLNEY (1895)

That there are circumstances under which a nation may justly interpose in a controversy to which two or more other nations are the direct and immediate parties is an admitted canon of international law. The doctrine is ordinarily ex- 
pressed in terms of the most general character and is perhaps incapable of more specific statement. It is declared in substance that a nation may avail itself of this right whenever what is done or proposed by any of the parties primarily concerned is a serious and direct menace to its own integrity, tranquillity, or welfare. The propriety of the rule when applied in good faith will not be questioned in any quarter. On the other hand, it is an inevitable though unfortunate consequence of the wide scope of the rule that it has only too of ten been made a cloak for schemes of wanton spoliation and aggrandizement. We are concerned at this time, however, not so much with the general rule as with a form of it which is peeuliarly and distinctively American. Washington, in the solemn admonitions of the Farewell Address, explicitly warned his countrymen against entanglements with the politics or the controversies of European powers. . . .

During the administration of President Monroe this doctrine of the Farewell Address was first considered in all its aspects and with a view to all its practical consequences. The Farewell Address, while it took America out of the field of European politics, was silent as to the part Europe might be permitted to play in America. Doubtless it was thought the latest addition to the family of nations should not make haste to prescribe rules for the guidance of its older members, and the expediency and propriety of serving the powers of Europe with notice of a complete and distinctive American policy excluding them from interference with American political affairs might well seem dubious to a generation to whom the French alliance, with its manifold advantages to the cause of American independence, was fresh in mind.

.. The Monroe administration, however, did not content itself with formulating a correct rule for the regulation of the relations between Europe and America. It aimed at also securing the practical benefits to result from the application of the rule. Hence the message just quoted declared that the American continents were fully occupied and were not the subjects for future colonization by European powers. To this spirit and this purpose, also, are to be attributed the passages of the same message which treat any infringement of the rule 
against interference in American affairs on the part of the powers of Europe as an act of unfriendliness to the United States. It was realized that it was futile to lay down such a rule unless its observance could be enforced. It was manifest that the United States was the only power in this hemisphere capable of enforcing it. It was therefore courageously declared not merely that Europe ought not to interfere in American affairs, but that any European power doing so would be regarded as antagonizing the interests and inviting the opposition of the United States.

Richard Olney, Letter to Mr. Bayard in Senate Executive Documents, 54 Cong. 1 session. (No. 31.)

\section{WOOLSEY (1896)}

But let us look at the real spirit and intent of the Monroe Doctrine. One hesitates to repeat its origin, so often has it been related. The allied powers had twice tried their hand at intervention - in Spain and in Naples. This intervention was in favor of absolutism, not of established goverument; for in Naples a liberal movement was put down, in Spain a royalist insurrection was helped up. Emboldened by success, they then proposed to apply their new principles to this continent, and to restore to Spain those colonies of hers which were trying to gain, or had gained, their independence. Then Monroe declared that such intervention would be regarded by the United States as dangerous to itself. He announced a policy. That policy forbade the substitution of monarchical for republican forms of government on this continent by European force. It did not forbid the existence of monarchies here, as Dom Pedro could testify. It did not forbid any step which the republics themselves chose to take, but simply what was forced upon them. It was the policy which fitted the hour and the occasion. It was opportunism.

The Monroe Doctrine is not a law; it binds us to no action; it was a policy devised to meet a particular case. That case was the forcible substitution of monarchical for republican forms of government in American States by European action. It was an act of self-defence, on no other grounds justifiable. It was not backed by threats of force.

Theodone S. Woolsey, America's Foreign Policy. 223-238. 
The Monroe Doctrine is a simple and plain statement that the people of the United States oppose the creation of European dominion on American soil; that they oppose the transfer of the political sovereignty of American soil to European powers; and that any attempt to do these things will be regarded as "dangerous to our peace and safety." What the remedy should be for such interposition by European powers the doctrine does not pretend to state. But this much is certain : that when the people of the United States consider anything " dangerous to their peace and safety" they will do as other nations (lo, and, if necessary, defend their peace and safety with force of arms.

The doctrine does not contemplate forcible intervention by the United States in any legitimate contest, but it will not permit any such contest to result in the increase of European power or influence on this continent, nor in the overthrow of an existing government, nor in the establishment of a protectorate over them, nor in the exercise of any direct control over their policy or institutions. Further than this the doctrine does not go.

John Bach McMaster, With the Fathers, 45.

\section{W. F. REDDAWAY (1898)}

In respect to the revolutionists of both hemispheres, then, the Monroe Doctrine is not in perfect harmony with the views of the President as previonsly expressed in public. It coincides, on the other hand, with the consistent teachings of Adams. Its keynote is the sharp political severance of America from Europe. In the month of Monroe, who had been wont to sound the praise of liberty in Spain, Portugal, and Greece, this rings false. With the strains of Adams it is in perfect harmony. ... During several years, then, Adams had steadily treated the supremacy of the United States on the continent of North America as an established fact, and the progress of events had caused him to declare their interest in the whole of the New World. The Monroe Doctrine, however, though it announces only that they camnot "behold with indif- 
ference" the extension of the political system of the Allies to any portion of the continent, speaks with warmth of those whom it terms "our Southern brethren." In this respect it savours more of Monroe than of Adams. . . . A single phrase, inserted perhaps by the President, or adopted by Adams as a harmless concession to the views of his colleagues, cannot of itself disprove his authority. . . .

The logical conclusion seems to be that the conception of the Monroe Doctrine and much of its phraseology came from Adams, and that the share of Monroe did not extend beyond revision. ...

In insisting upon the right of every people to choose its own form of government without external interference, also, the declaration is affirming but not creating, the Law of Nations. The kernel of this part of the Monroe Doctrine then in its second form as in its first, is a vague declaration of policy and in no way a formulation of rules prevailing between states. . . . No line or paragraph of the Monroe Doctrine, therefore, represents an addition to the body of rules prevailing between States. From the first word to the last, it is a declaration of the policy of a single power. ...

In its latest development, then, as throughout its history, the Monroe Doctrine has induced confusion of thought. The flood of sentiment and rhetoric poured out on both sides of the Atlantic has in great part obscured the truth. It has served, none the less, to establish the position of the Monroe Doctrine as a political force, which - however esteemed must be recognized. Above all, by the Old World and the New, it must be understood.

William Fiddian Reddaway, Monroe Doctrine. 82-151.

HART (1901)

No one who knows the cautious and somewhat sluggish mind of Monroe could suppose $a$ priori that he had the genius to meet and counteract the double danger; the real author and probable penman of the famous declaration of 1823 was John Quincy Adams, then Secretary of State. He had already rapped the knuckles of the Russian ambassador on the Oregon question, and he threw all his immense energy into the task of nerving 
up the President to a strong announcement. The result was the annual message of December 2, 1823, embodying what was thereafter called "The Monroe Doctrine," the essentials of which are three statements.

-.. It will be seen that the Monroe doctrine was not intended by Monroe to be a code of international law, but was called out by a special set of circumstances long since outgrown - aggressions by Russia and by allied Europe. So far as it referred to the future, the doctrine was intended to state a kind of quid pro quo.

. . The extension of the term Monroe Doctrine from the limited form given it by John Quincy Adams to that stated by Secretary Olney has of course a reason: there is an apparent advantage, when the United States takes up a position in American diplomacy, in bringing it within the Monroe Doctrine; because it may then be urged that foreign powers which ignore or question our positions have had many decades of notice, and hence are sinning against light. But it is impossible to appeal to a part of the principle and to ignore the rest; and the history of the doctrine shows absolutely that down to 1895 the United States always asserted a special American influence, on the ground that it left to European powers a similar special interest in Europe. This is simply a doctrine of the permanent subdivision of the earth into two spheres of influence, each of which could get on witlout the other, and in each of which the interference of the other would be unwarranted. There was really no such separation in 1823 , and every year draws the ends of the earth closer together. To claim the Monroe Doctrine as still our guiding principle is to suggest to other nations that the United States has no power outside America. The two areas are not separate and never can be separated; the United States is a world power, and cannot claim the special privileges of a diplomatic recluse, and at the same time the mastery of the Western Hemisphere.

\footnotetext{
Albert Bushell Hart, The Monroe Doctrine, in Harper's Monthly, 1901.
} 


\section{Chapter XXI}

\section{THE RIGHTS OF SLAVES AND OF THEIR RACE}

\section{SUGGESTIONS}

The Dred Scott Decision was pronounced on the 6th of March, 1857. The following excerpts are chosen from the reports made by ChiefJustice Taney, and the dissenting opinion delivered by Justice Curtis.

The interest which gathers about the question of slavery and its eventual death-blow has to this generation of students a purely historic bearing; but that slavery did exist, and that it was possible for the Chief Justice of the Supreme Court to defend it in an official report, makes the study of one of the most famous decisions of the Court a necessary preparation for the later investigation of the enfranchisement of the coloured race. In examining the opinion of the Court, we are amazed that less than fifty years ago such conditions could have existed. To appreciate fully these discussions for and against the Dred Scott Decision, it is necessary to study into the Northern and Southern points of view, and to investigate the social conditious, and the moral energy which had their share in shaping the doctrines and politics of the respective leaders in this great issue.

For Outlines and Material, see Appendix B.

\section{DOCUMENTS}

Extracts from the Opinion of the Court in the Dred Scott Decision, March 6th, 1857

The text is Mr. Chief Justice Roger B. Taney delivered the

from 19 How- opinion of the Court.
ard, 399 . Dred Scott, a This case has been twice argued. After the arslave born in gument at the last term, differences of opinion were Missouri, having lived north of the found to exist among the members of the Court; and as the questions in controversy are of the high- 
est importance, and the Court was at that time Missouri line much pressed by the ordinary business of the term, for four much presserl by the orinary business of the term, years, it was deemed advisable to continue the case, and claimed his direct a re-argument on some of the points, in order freedom, that we might have an opportunity of giving to the Sandford, whole subject a more deliberate consideration. It who had lias accordingly been again argued by counsel, and become his considered by the Court; and I now proceed to after his redeliver its opinion. $\quad$ turu south of titular owner

There are two leading questions presented by the mise line. record : The Circuit Court of Mis.

1. Had the Circuit Court of the United States sourt decided jurisdiction to hear and determine the case between in his favour. these parties? And The Supreme Court of Mis-

2. If it had jurisdiction, is the judgment it has souri regiven erroneous or not?

The plaintiff in in the Court below, was, with his wife and children, it back. held as slaves by the defendant, in the State of In Nov., Missouri; and he brought this action in the Circuit Scott entered Court of the United States for that district, to assert suit against the title of himself and his family to freedom.

The declaration is in the form usually adopted in Circuit Court of the United thates. that State to try questions of this description, and Sandford decontains the averment necessary to give the Court nied the jurisdiction ; that he and the defendant are citizens jurisdicof different States; that is, that he is a citizen of the Court of Missouri, and the defendant a citizen of New York. and then de-

The defendant pleaded in abatement to the juris- cided against diction of the Court, that the plaintiff was not a Dred Scott citizen of the State of Missouri, as alleged in his of the decideclaration, being a negro of African descent, whose sion of the ancestors were of pure African blood, and who were higher Court. brought into this country and sold as slaves.

To this plea the plaintiff demurred, and the de- case came up fendant joined in demurrer. The Court overruled preme Court the plea, and gave judoment that the defendant of the United should answer over. And he therefore put in sun- which Dred dry pleas in bar, upon which issues were joined; $\begin{aligned} & \text { Scott had } \\ & \text { finally ap- }\end{aligned}$ 
pealed, and decision was rendered in March, 1857. and at the trial the verdict and judgment were in his favor. Whereupon the plaintiff brought this writ of error.

Before we speak of the pleas in bar, it will be proper to dispose of the questions which have arisen on the plea in abatement.

That plea denies the right of the plaintiff to sue in a court of the United States, for the reasons therein stated.

If the question raised by it is legally before us, and the Court should be of opinion that the facts stated in it disqualify the plaintiff from becoming a citizen, in the sense in which that word is used in the Constitution of the United States, then the judgment of the Circuit Court is erroneous, and must be reversed.

It is suggested, however, that this plea is not before us; and that as the judgment in the Court below on this plea was in favor of the plaintiff, he does not seek to reverse it, or bring it before the Court for revision by his writ of error ; and also that the defendant waived this defence by pleading over, and thereby admitted the jurisdiction of the Court. ...

Constitution, The words 'people of the United States' and Art.iv. sect. ' citizens' are synonymous terms, and mean the 2. same thing. They both describe the political body who, according to our republican institutions, form the sovereignty, and who hold the power and conduct the government through their representatives. They are what we familiarly call the 'sovereign people,' and every citizen is one of this people, and a constituent member of this sovereignty. The question before us is, whether the class of persons described in the plea in abatement compose a portion of this people, and are constituent members of

Constitution, this sovereignty? We think they are not, and that Art. iv. sect. they are not included, and were not intended to be $2, \S \S 1,2,3$. included, under the word 'citizen' in the Consti- 
tution, and can therefore claim none of the rights and privileges which that instrument provides for and secures to citizens of the United States.

On the contrary, they were at that time considered as a subordinate and inferior class of beings, who had been subjugated by the dominant race, "Three fifths and, whether emancipated or not, yet remained of all other subject to their authority, and had no rights or Constitution, privileges but such as those who held the power and Art. i. sect. the government might choose to grant them.

It is not the province of the Court to decide upon the justice or injustice, the policy or impolicy, of these laws. The decision of that question belonged to the political or law-making power; to those who formed the sovereignty and framed the Constitution. The duty of the Court is, to interpret the instrument Constitution, they have framed, with the best lights we can obtain Art. iii. sect. on the subject, and to administer it as we find it, according to its true intent and meaning when it was adopted.

In discussing this question, we must not confound the rights of citizenship which a State may confer within its own limits, and the rights of citizenship as a member of the Union. It does not by any means follow, because he has all the rights and privileges of a citizen of a State, that he must be a Fourteenth citizen of the United States. He may have all of amendment the rights and privileges of the citizen of a State stitution and yet not be entitled to the rights and privileges makes it so. of a citizen in any other State. For, previous to the adoption of the Constitution of the United States, every State had the undoubted right to confer on whomsoever it pleased the character of citizen, and to endow him with all its rights. But this charac- Articles of ter of course was confined to the boundaries of Confederathe State, and gave him no rights or privileges in other States beyond those secured to him by the laws of nations and the comity of States.

No one, we presume, supposes that any change 
England abolished slavery in $183: 3$; the purchasemoney given by Great

Britain to the slaveowners was $20,000,000 l$.

in public opinion or feeling in relation to this unfortunate race, in the eivilized nations of Europe or in this country, should induce the courts to give to the words of the Constitution a more liberal construction in their favor than they were intended to bear when the mstrument was framed and adopterl. Such an argument would be altogether inadmissible in any tribunal called on to interpret it. If any of its provisions are deemed unjust, there is a mode prescribed in the instrument itself by which it may be amended; but while it remains unaltered, it must be construed now as it was understood at the time Const. Art. v. of its adoption. It is not only the same in words but the same in meaning, and delegates the same power to the government and reserves and secures the same rights and privileges to the citizen; and, as long as it continues to exist in its present form, it speaks not only with the same words, but with the same meaning and intent with which it spoke when it came from the hauds of its framers, and was voted on and adopted by the people of the United States. Any other rule of construction would abrogate the judicial character of this Court, and make it the mere reflex of the popular opinion or passion of the day. This Court was not created by the Constitution for such purposes. Higher and graver trusts have been confided to it, and it must not falter in the path of duty.

This dictum is successfully refuted by George Livermore, Historical Research.
What the construction was at that time, we think can hardly admit of doubt. We have the language of the Declaration of Independence and of the Articles of Confederation, in addition to the plain words of the Constitution itself ; we have the legislation of the different States, before, about the time, and since, the Constitution was adopted; we have the legislation of Congress, from the time of its adoption to a recent period; and we have the constant and uniform action of the executive department, all concurring together, and leading to 
the same result. And if anything in relation to the construction of the Constitution can be regarded as settled, it is that which we now give to the word "citizen" and the word "people."

And upon a full and careful consideration of the subject, the Court is of opinion, that, upon the facts stated in the plea in abatement, Dred Scott was not a citizen of Missouri within the meaning of the Constitution of the United States, and not entitled as such to sue in its courts ; and, consequently, that the Circuit Court has no jurisdiction of the case, and that the judgment on the plea in abatement is erroneous. ...

Now, as we have already said in an earlier part of this opinion, upon a different point, the right of property in a slave is distinctly expressed and affirmed in the Constitution. The right to traffic in it, like an ordinary article of merchandise and property, was guaranteed to the citizens of the United States, in every State that might desire it, for twenty years. And the government in express Const. Art. i. terms is plenged to protect it in all future time, if sect. $9, \S 1$. the slave escapes from his owner. This is done in plain words - too plain to be misunderstood. And Const. Art. no word can be found in the Constitution which $\S 2$. gives Congress a greater power over slave property, or which entitles property of that kind to less protection than property of any other description. The only power conferred is the power coupled with the duty of guarding and protecting the owner in his rights.

Upon these considerations, it is the opinion of the Court that the Act of Congress which prohibited a citizen from holding and owning property of this kind in the territory of the United States north of "Missouri the line therein mentioned, is not warranted by comprothe Constitution, and is therefore void; and that unconstituneither Dred Scott himself, nor any of his family, tional. were made free by being carried into this terri- 
tory; even if they had been carried there by the owner, with the intention of becoming a permanent resident.

Extract from Justice Benjamin R. Cuntis, dissenting.

I dissent from the opinion pronounced by the Chief Justice, and from the judgment which the majority of the court think it proper to render in this case. ...

One mode of approaching this question is, to inquire who were citizens of the United States at the time of the adoption of the Constitution.

Citizens of the United States at the time of the adoption of the Constitution can have been no other than citizens of the United States under the

See Const. Art.iv. sect. 2, Arts. of Confed., ii.

Note Declaration of Independence.
Confederation. By the Articles of Confederation, a Government was organized, the style whereof was, 'The United States of America.' This Government was in existence when the Constitution was framed and proposed for adoption, and was to be superseded by the new Government of the United States of America, organized under the Constitution. When, therefore, the Constitution speaks of citizenship of the United States, existing at the time of the adoption of the Constitution, it must necessarily refer to citizenship under the Government which existed prior to and at the time of such adoption.

Without going into any question concerning the powers of the Confederation to govern the territory of the United States out of the limits of the States, and consequently to sustain the relation of Government and citizen in respect to the inhabitants of such territory, it may safely be said that the citizens of the several States were citizens of the United States under the Confederation. . . .

Did the Constitntion of the Inited States deprive them or their descendants of citizenship? 
That Constitution was ordained and established by the people of the United States, through the action, in each State, of those persons who were qualified Through the by its laws to act thereon, in behalf of themselves ratification and all other citizens of that State. In some of the stitution. States, as we have seen, colored persons were among those qualified by law to act on this subject. These Instanced by colored persons were not only included in the body New Hampof 'the people of the United States,' by whom the chusetts, Constitution was ordained and established, but in New York, at least five of the States they had the power to act, and North and doubtless did act, by their suffrages, upon the Carolina, question of its adoption. It would be strange, if where memwe were to find in that instrument anything which colored race deprived of their citizenship any part of the people were not of the United States who were among those by but citizens whom it was established.

I can find nothing in the Constitution which, "franchise proprio vigore, deprives of their citizenship any class of persons who were citizens of the United States at the time of its adoption, or who should be native-born citizens of any State after its adoption; nor any power enabling Congress to disfranchise persons born on the soil of any State, and entitled to citizenship of such State by its Constitution and laws. And my opinion is, that, under the Constitution of the United States, every free person born on the soil of a State, who is a citizen of that State by force of its Constitution or laws, is also a citizen of the United States.

The conclusions at which I have arrived on this part of the case are :

First. That the free native-born citizens of each Citizenship. State are citizens of the United States.

Second. That as free colored persons born within some of the States are citizens of those States, such Colored citipersons are also citizens of the United States. 
Rights of citizenship.

This refers to the ground taken by Taney that all territory acquired after the year 1787 was under the constitutional law of the country. Hence, citizenship from the Federal Government could not extend to the new territories.

Louisiana Purchase.
Thurd. That every such citizen, residing in any State, has the right to sue and is liable to be sued in the Federal courts, as a citizen of that State in which be resides.

Fourtir. That as the plea to the jurisdiction in this case shows no facts, except that the plaintiff was of African descent, and his ancestors were sold as slaves, and as these facts are not inconsistent with his citizenship of the United States, and his residence in the State of Missouri, the plea to the jurisdiction was bad, and the judgment of the Circuit Court overruling it was correct.

I dissent, therefore, from that part of the opinion of the majority of the court, in which it is held that a person of African descent cannot be a citizen of the United States; and I regret I must go further, and dissent both from what I deem their assumption of authority to examine the constitutionality of the act of Congress commonly called the Missouri Compromise act, and the grounds and conclusions announced in their opinion.

I consider the assumption which lies at the basis of this theory to be unsound; not in its just sense, and when properly understood, but in the sense which has been attached to it. That assumption is, that the territory ceded by France was acquired for the equal benefit of all the citizens of the United States. I agree to the position. But it was acquired for their benefit in their collective, not their individual, capacities. It was acquired for their benefit, as an organized political society, subsisting as 'the people of the United States,' under the Constitution of the United States; to be administered justly and impartially, and as nearly as possible for the equal benefit of every individual citizen, according to the best judgment and discretion of the Congress; to whose power, as the Legislature of the nation which acquired it, the people of the United States have committed its administration. 
Nor in my judgment, will the position, that a prohibition to bring slaves into a Territory deprives any one of his property without due process of law, bear See Magna examination. 39.

It must be remembered that this restriction on See Conthe legislative power is not peculiar to the Constitn- firmatio the legislative power is not peculiar to the Constitu- Chartarum, tion of the United States; it was borrowed from Art. I. Magna Charta; was brought to America by our See Petition ancestors, as part of their inherited liberties, and See Bill of has existed in all the States, usually in the very Rights, Art. words of the great charter.

\section{CONTEMPORARY EXPOSITION}

BENTON (1857)

From the day of becoming a landholder, the old Continental Congress first, and the Federal Congress since, have exercised the right of every other landholder to prevent trespasses, intrusions, and settlements upon their territory, expelling with military force, and punishing with fine and damages, the violater of its rules.

This began under the Confederation, and has continued ever since. All the old settlers on the frontiers can remember the dragooning the settlers on the United States territory, driving them off, and destroying their houses and growing crops. All can remember the old familiar operation of cutting up a Territory, running a line through it, giving one half to the Indians, and driving the white people from it, and their slaves also. Such is the power which Congress exercises over its territory, and with which the Constitution has nothing to do.

To sum up, in a few words, the results of this Examination, and to present the conclusions under a single view, and it is shown that the Constitution was not made for Territories, and does not include them - that it cannot be extended to them by law, and if it could, would be barren and fruitless without. law to put it into operation - that no law could be made under it to give any help to the slaveholder, either in recovering his property, if the slave ran away, or in bringing back for justice 
the fugitive felon that should steal it; or in getting protection from the Federal Government against revolt, or in that acknowledgment of property in the slave which results from his federal taxation. In no one of these cases, nor in any other one which can be imagined, can any law be made under the Constitution to help the slave-owner, for every provision in that instrument which relates to slavery is confined to States; and the owner must be thrown upon the ordinance of 1787, and the power of Congress, independent of the Constitution, for every species of protection which he may need about that property.

I have performed an unpleasant task, but unavoidable. I have been on the kindest personal terms with the judges, and in my long senatorial service, and as part of the appointing power, have cordially given my voice for the elevation of each of them to the honourable stations they hold - for every one except Mr. Justice Curtis, appointed since the termination of my service. I am a friend to the Supreme Court as an institution - as a high and essential part of our system - and would not willingly derogate from its respect, or impair its ntility. But the whole system, of which it is a part, and the whole people, of whom its members are a few, are overruling considerations; and the evil of the late decision being actually upon us, going into parties, entering into elections, giving the rule for the appointment of all future federal judges, establishing a new party test, bringing the federal judiciary into the vortex of federal politics, and developing still more strongly the geographical line which divides us; seeing all these evils now upon us, and others to come, I have found it impossible to remain silent, or to have said less. I am among the last of those who, acting with the generations that are passed, still adhere to their teaehings. I labour to preserve what they established, lamenting that the task had not fallen into abler hands. A few years earlier, and the preservation of the Missouri Compromise would have found its adequate defender in one of its greatest architects, and the integrity of the Constitution would have found its champion in its great expounder; but Clay and Webster are gone; and, before them, went Pinckney and Lowndes, gloriously identified with the work which recent hands have just torn 
down. And of those who survive, and who stood by them in their great efforts, and still stand where they stood, I am one of the few - no longer in power, but still in armour when the works of our fathers are in danger. I write for no party, but for all men who venerate the works of our ancestors, and who wish to see our Government kept on the foundations on which they placed it.

Tromas H. Benton, Examination of the Supreme Court's Decision in the Dred Scott Case. 128, 130.

BANCROFT (1862)

That ill-starred disquisition is the starting-point of this rebellion, which, for a quarter of a century, had been vainly preparing to raise its head. "When courts of justice fail, war begins." The so-called opinion of Taney, who, I trust, did not intend to hang out the flag of disunion, that rash offence to the conscious memory of the millions, upheaved our country with the excitement which swept over those of us who vainly hoped to preserve a strong and sufficient though narrow isthmus that might stand between the conflicting floods. No nation can adopt that judgment as its rule, and live: the judgment has in it no element of political vitality. I will not say it is an invocation of the dead past: there never was a past that accepted such opinions. If we want the opinions received in the days when our Constitution was framed, we will not take them second-hand from our Chief-Justice: we will let the men of that day speak for themselves. How will our American magistrate sink, when arraigned, as he will be, before the tribunal of humanity! How terrible will be the verdict against him, when he is put in comparison with Washington's political teacher, the great Montesquieu, the enlightened magistrate of France, in what are esteemed the worst days of her monarchy! 'The argument from the difference of race which 'Taney thrusts forward with passionate confidence, as a proof of complete disqualification, is brought forward by Montesquieu as a scathing satire on all the brood of despots who were supposed to uphold slavery as tolerable in itself. The rights of mankind - that precious word which had no equivalent in the language of Hindostan, or Judæa, or Greece, or Rome, or any ante-Clristian tongue - found 
their supporter in Washington and Hamilton, in Franklin and Livingston, in Otis, George Mason, and Gadsden; in all the greatest men of our early history. 'The one rule from which the makers of our first Confederacy, and then of our national Constitution, never swerved, is this: to fix no constitutional disability on any one. Whatever might stand in the way of any man, from opinion, ancestry, weakness of mind, inferiority or inconvenience of any kind, was itself not formed into a permanent disfranchisement. The Constitution of the United States was made under the recognized influence of "the eternal rule of order and right;" so that, as far as its jurisdiction extends, it raised at once the numerous class who had been chattels into the condition of persons : it neither originates nor perpetuates inequality.

George Bancroft, Pulpit and Rostrum. 104-107.

GREELEY (1865)

Chief Justice Taney, in pronouncing the decision of the Court, which nullified the Missouri Restriction, or any restriction by Congress on the boundless diffusion of Slavery throughout the territories of the Union, commenced by denying to Dred Scott, or to any person "whose ancestors were imported to this country and sold as slaves," any right to sue in a court of the United States. ...

The Chief Justice proceeds to affirm, not only that no persons who had been, or whose ancestors had been, slaves, were regarded as citizens previously to, or at the time of, adopting the Federal Constitution, but that no State has, or can have, any right to confer citizenship on such persons. Bearing in mind the citations from our revolutionary and post-revolutionary history, ... the reader will be puzzled to decide whether Law, Humanity, or History, is most flagrantly defied. . . . The immortal language of the preamble to the Declaration of Independence, wherein "life, liberty, and the pursuit of happiness," are proclaimed the self-evident, inalienable rights of all men, might well stagger the most brazen and subtle attorney, but not a case-hardened Chief Justice. . . Justice Curtis is an ultra conservative of the State-street (Boston) school - a lifelong follower of Mr. Webster.... 
Though couched in judicial and respectful language, it constantly, and pretty clearly, intimates not merely that the judgment of the Court is contrary both to law and to fact, but that its authors well know such to be the case. . . . Judge Curtis says: "It has been often asserted that the Constitution was made exclusively by and for the white race. It has already been shown that, in five of the thirteen original States, coloured persons then possessed the elective franchise, and were among those by whom the Constitution was ordained and established. If so, it is not true, in point of fact, that the Constitution was made exclusively by the white race. And that it was made exclusively for the white race is, in my opinion, not only an assumption not warranted by anything in the Constitution, but contradicted by its open declaration, that it was ordained and established by the people of the United States, for themselves and their posterity. And, as free coloured persons were then citizens of at least five States, and so, in every sense, part of the people of the United States, they were among those for whom and whose posterity the Constitution was ordained and established."

Horace Greeley, The American Conflict, a History of the Great Rebellion. I. 253-262, passin.

\section{WILSON (1877)}

The dissenting opinion of Justice Curtis was very decided, thorough, fortified by an impregnable array of authorities, and, from his well-known conservatism, worthy of special notice. In reply to the assertion of the majority that the negro was not a "citizen," he asserted that "the citizens of the several States were citizens of the United States under the confederation," and he instanced the fact that all free native-born inhabitants of the States of New Hampshire, Massachusetts, New York, New Jersey, and North Carolina, though descended from African slaves, were not only " citizens," but many of them had "the franchise of electors." . . . Nor did the fact that in some States they were deprived of some of the rights possessed by the whites militate against their citizenship. "The truth is," said Judge Curtis, "that citizenship, under the Constitution of the United States, is not dependent on the possession of any particular political or even of any civil rights."

Henny Wruson, Rise and Fall of the Slave Power in America. II. 530. 


\section{CRITICAL COMMENT}

VON HOLST (1875)

Not only was there no need of the decree [Taney's decision as to the constitutional law respecting citizenship], but it was against right and issued confessedly on political grounds. The opinions of the majority differed from one another in their argumeutation, and to some extent in their concessions, so widely that, taken together, they constituted an inextricable tangle, and two of the judges not only opposed the chief justice on one point after another, but the severest moral condemnation could be heard in their juridico-historical deductions, spite of their calmness and strict pragmatism.

Hermaxy E. von Holst, Constitutional and Political History of the United States. VI. 45, 46.

\section{SCHOULER (1891)}

The defendant slave-holder pleaded to the circuit jurisdiction that Dred Scott was not in any case "a citizen entitled to sue," because a negro of African descent; that plea the court overruled, and, in May, 1854, sent the case to a jury, in accordance with whose verdict judgment was rendered that the plaintiff was still properly a slave; and then the whole record went on final appeal to the tribunal in Washington. Not referees, to be sure, at their own instance, the nine silk gowns, all Democrats but one, and five of them from the States where colour presumed servitude, listened patiently to the arguments of counsel favourable to one political aspect of the case or another. Argued at the winter term which preceded this last Presidential canvass, reargued at the next term following the election, this case was not decided till the churn of legislation overhead had ceased and the President-elect was inducted into office; after which, the oracle which Southern statesmen behind the scenes had been trying for many weeks to pry open was gravely unsealed.

It was an extraordinary decision, certainly, for the third quarter of the nineteenth century, and extraordinary in more senses than one... 
Melancholy must have been the spectacle in this cavern of justice, through whose eastern windows glanced the sunbeams as into some mausoleum, when the Chief Justice, a man of frail and attenuated frame, read to a large audience of the bar, in a low tone of voice almost inaudible, the majority opinion prepared by himself. Elaborate, adroitly put together and cruel, it doomed the African of this age by the standard of three centuries ago, - exploring musty and worm-eaten codes, and announcing far too broadly that, at the date our Federal Constitution was arlopted, negroes had been and were still regarded as beings of an inferior order, "and so far inferior that they had no rights which the white man was bound to respect." That curdling phrase was not forgotten; and, though Taney uttered it merely as an historical conclusion, our people believed it to express the real sentiment entertained by himself and his Southern colleagues on the bench towards the oppressed; and in that sense they interpreted it. Taney had many admirable traits of character, being learned in the law, painstaking, upright, and full of dignity; that he could take odium unflinchingly he had shown when, as Jackson's secretary he removed the deposits. But he was wanting in the flow of healthy blood, and henceforth to a large fraction of Americans he seemed almost a vampire, hovering in the dim twilight. Not difficult was it to rake together a heap of rubbish testimony from colonial acts, the writings of European publicists, and the statute-books moreover of our original thirteen States. But where was the clear letter of the Constitution that set an eternal doom upon the inheritors of an Ethiopian skin? For Indians, it was admitted, the red race, were placed in no such unfortunate category. Where was the rising sun of the American revolution, to dissipate this festering mass of misconception? Where were the hopes, the wishes, cherished by Franklin, by Washington, by Jefferson, Adams, Hamilton, Madison, and all the chief framers and expounders of our perfected Federal system, under whose benign influence freedom was carried into new territories?

James Schodler, History of the United States. V. 378-380 


\section{RHODES (1893)}

The opinion of Taney was but the doctrine of Calhoun, announced for the first time in 1847 , and now embodied in a judicial decision. . . . Only by the conviction that slavery was being pushed to the wall, in conjunction with subtle reasoning like that of Calhoun, who tried to obstruct the onward march of the century by a fine-spun theory, could a sentiment have been created which found expression in this opinion of Taney, outraging as it did precedent, history, and justice.

That Taney committed a grievous fault is certain. He is not to be blamed for embracing the political notions of John C. Calhoun; his environment gave that shape to his thoughts; but he does deserve censure because he allowed himself to make a political argument, when only a judicial decision was called for. . . . Nothing but an imperative need should have led judges, by their training and position presumably conservative, to unsettle a question that had so long been acquiesced in. The strength of a constitutional government lies in the respect paid to settled questions. . . .

If Taney spoke for Calhoun, Curtis spoke for Webster. . . . If 'Taney furnished arguments for the Democrats, Curtis showed that the aim of the Republicans was constitutional. . . .

Justice Curtis rose to the height of the situation, and in his opinion gave the key-note to the constitutional argument against the opinion of the court being in any way binding on the political consciences of the people. ...

Not Republicans alone saw the matter in this light under the guidance of so earnest and able a jurist.

James Fond Rhodes, History of the United States. II. 260-263.

BRYCE (1896)

Whenever the Constitution has conferred a power of legislating upon Congress, the Court declines to inquire whether the use of the power was in the case of a particular statute passed by Congress either necessary or desirable, or whether it was exerted in a prudent manner, for it holds all such matters to be within the exclusive province of Congress. . . .

Adherence to this principle has enabled the Court to avoid 
an immixture in political strife which must have destroyed its credit, has deterred it from entering the political arena, where it could have been weak, and enabled it to act without fear in the sphere of pure law, where it is strong. . . Occasionally, however, it has been required to give decisions which have worked with tremendous force on politics. The most famous of these was the Dred Scott case, iu which the Supreme Court, on an action by a negro for assault and battery against the person claiming to be his master, declared that a slave taken temporarily to a free State and to a Territory in which Congress had forbidden slarery, and afterwards returning into a slave State and resuming residence there, was not a citizen capable of suing in the Federal courts if by the laws of the slave State he was still a slave. This was the point which actually called for a decision; but the majority of the court, for there was a dissentient minority, went further, and delivered a varicty of dicta on various other points touching the legal status of negroes, and the constitutional view of slavery.

James Bryce, American Commonwealth. ${ }^{1} \quad$ 189, 190.

I Copyright, 1896, by the Macmillan Co. 


\section{ChaPTER XXII}

\section{EMANCIPATION OF THE SLAVES (1862-1863)}

\section{SUGGESTIONS}

IN Barrett's biography of Abraham Lincoln, it is stated that the first rough draft of the Emancipation Proclamation was written on board ship as the President was returning from his visit to the army at Harrison's Landing, the 8th of July. The original official draft is dated September 22nd, 1862, and was presented to the Army Relief Bazaar at Albany, N. Y., in 1864. It is in the handwriting of Presi. dent Lincoln, excepting two interlineations in pencil, by Secretary Seward, and the formal heading and ending, which were written by the chief clerk of the State Department. The final Proclamation was signed on New Year's Day, 1863.

These documents demand close study: the preliminary proclamation has a background of military as well as political history, which is of the greatest importance; and in the study of the final document the student should take into consideration the story of Lincoln's life; the anecdotes and incidents grouping themselves around the abolitionists of the North; the home life upon the Southern plantation; the long struggle between the two great parties in Congress, problems which preceded the Proclamation of 1863.

For Outlines and Material, see Appendix B.

\section{DOCUMENTS}

\section{Preliminary Proclamation of Emancipation}

September 22, 1862.

Text taken I, Abraham Lincoln, President of the United from Abra- States of America, and commander-in-chief of the hamplete Works, ii. 237. clare that hereafter, as heretofore, the war will be Note that Lincoln was the head of the Army prosecuted for the object of practically restoring the constitutional relation between the United States, and each of the States, and the people thereof, in 
which States that relation is or may be suspended or according to disturbed.

Const. Art.

'That it is my purpose, upon the next meeting of ii. sec. ii. Congress, to again recommend the adoption of a mis proclapractical measure tendering pecuniary aid to the kept back free acceptance or rejection of all slave States so until after called, the people whereof may not then be in rebel- at Antietam. lion against the United States, and which States Lincoln had may then have voluntarily adopted, or thereafter vowed to may voluntarily adopt, immediate or gradual abol- himself to ishment of slavery within their respective limits; promise to and that the effort to colonize persons of Afri- issue such a and that the eftort to colonize persons can descent, with their consent, upon this conti- if the "rebel nent or elsewhere, with the previously obtained army" were there, will driven out. be continued.

In December the House

That on the first day of January, in the year of passed a resour Lord one thousand eight hundred and sixty- approve the three, all persons held as slaves within any State, or President's designated part of a State, the people whereof shall policy. then be in rebellion against the United States, shall be then, thenceforward, and forever free; and the Executive Government of the United States, including the military and naval authority thereof, will recognize and maintain the freedom of such persons, and will do no act or acts to repress such persons, or any of them, in any efforts they may make for their actual freedom.

'That the Executive will, on the first day of January See Final aforesaid, by proclamation, designate the States Proclamaand parts of States, if any, in which the people thereof respectively shall then be in rebellion against Nosuch conthe United States; and the fact that any State, or dition was the the people thereof, shall on that day be in good faith about berepresented in the Congress of the United States, by tween Sept. members chosen thereto at elections wherein a ma- Jan. 1, 1863. jority of the qualified voters of such State shall have participated, shall, in the absence of strong countervailing testimony, be deemed conclusive evidence 
Refusal of government to uphold Fugitive Slave Law.
"Contrabands" become free men. that such State, and the people thereof, are not then in rebellion against the United States.

That attention is hereby called to an act of Congress entitled "An act to make an additional article of war," approved March 13th, 1862, and which act is in the words and figures following:

"Be it enacted by the Senate and House of Representatives of the United States of America in Congress assembled, That hereafter the following shall be promulgated as an additional article of war for the government of the army of the United States, and shall be obeyed and observed as such:

"Article - All officers or persons in the military or naval service of the United States are prohibited from employing any of the forces under their respective commands for the purpose of returning fugitives from service or labour who may have escaped from any persons to whom such service or labour is claimed to be due; and any officer who shall be found guilty by a court-martial of violating this article shall be dismissed from the service."

"Section 2. And be it further enacted, That this act shall take effect from and after its passage."

Also, to the ninth and tenth sections of an act entitled "An act to suppress insurrection, to punish treason and rebellion, to seize and confiscate property of rebels, and for other purposes," approved July 17, 1862, and which sections are in the words and figures following:

"SEc. 9. And be it further enacted, That all slaves of persons who shall hereafter be engaged in rebellion against the government of the United States, or who shall in any way give aid or comfort thereto, escaping from such persons and taking refuge within the lines of the army; and all slaves captured from such persons, or deserted by them, and coming under the control of the government of the United States; and all slaves of such persons found on [or] being within any place occupied by 
rebel forces and afterwards oceupied by forces of the United States, shall be deemed captives of war, and shall be forever free of their servitude, and not again held as slaves.

"SEc. 10. And be it further enacted, That no slave escaping into any State, Territory, or the District of Columbia, from any other State, shall be Practically delivered up, or in any way impeded or hinclered of his liberty, except for crime or some offense against the laws, unless the person claiming said fugitive shall first make oath that the person to whom the labour or service of such fugitive is alleged to be due is his lawful owner, and has not borne arms against the United States in the present rebellion, nor in any way given aid and comfort thereto; and no person engaged in the military or naval service of the United States shall, under any pretence whatever, assume to decide on the validity of the claim of any person to the service or labour of any other person, or surrender up any such person to the claimant, on pain of being dismissed from the service."

And I do hereby enjoin upon and order all persons engaged in the military and naval service of the United States to observe, obey, and enforce, within their respective spheres of service, the act and sections above recited.

And the Executive will in due time recommend that all citizens of the United States who shall have remained loyal thereto throughout the rebellion shall (upon the restoration of the constitutional relation between the United States and their respective States and people, if that relation shall have been suspended or disturbed) be compensated for all losses by acts of the United States, including the loss of slaves.

In witness whereof, I have hereunto set my hand, and caused the seal of the United States to be affixed.

this was a repeal of the

Fugitive

Slave Act of 1852.
Compen-

sated emancipation

proved ineffectual.

This proclamation had been talked of for montlis by the clergy, the press, and politicians. It was not until the President 
deemed it Done at the city of Washington, this twenty-second prudent that it was even drafted (July 8 th). It was then laid aside for the the eighty-serenth. day of September, in the year of our Lord [L. s.] one thousand eight bundred and sixty-two, and of the Independence of the United States ripening of later events.

By the President:

Wm. H. Seward, Secretary of State.

Final Proclamation of Emancipation.

$$
\text { January 1, } 1863 .
$$

Text from Abraham Lincoln, Complete Works, II. 287.

See preceding document.
Whereas, on the twenty-second day of September, in the year of our Lord one thousand eight hundred and sixty-two, a proclamation was issued by the President of the United States, containing, among other things, the following, to wit:

" That on the first day of January, in the year of our Lord one thousand eight hundred and sixtythree, all persons held as slares within any state or designated part of a state, the people whereof shall then be in rebellion against the United States, shall be then, thenceforward, and forever free; and the Executive Grovernment of the United States, including the military and naval authority thereof, will recognize and maintain the freedom of such persons, and will do no act or acts to repress such persons or any of them, in any efforts they may make for their actual freedom.

"That the Executive will, on the first day of January aforesaid, by proclamation, designate the states and parts of states, if any, in which the people thereof respectively shall then be in rebellion against the United States; and the fact that any state, or the people thereof, shall on that day be in good faith represented in the Congress of the United States, by members chosen thereto at elections wherein a majority of the qualified voters of such state shall have participated, shall, in the ab- 
sence of strong countervailing testimony, be deemed conclusive evidence that such state, and the people thereof, are not then in rebellion against the United States."

Now, therefore, I, Abraham Lincoln, President By virtue of of the United States, by virtue of the power in me his power as commandervested as commander-in-chief of the arny and navy in-chief "in of the United States in time of actual armed rebel- time of aclion against the authority and government of the rebellion." United States, and as a fit and necessary war measure for suppressing said rebellion, do, on this first day of January, in the year of our Lord one thousand eight hundred and sixty-three, and in accordance with my purpose so to do, publicly proclaimed for the full period of 100 days from the day first above mentioned, order and designate, as the states and parts of states wherein the people thereof respectively are this day in rebellion against the United States, the following, to wit:

Arkansas, Texas, Louisiana (except the parishes Tennessee of St. Bernard, Plaquemine, Jefferson, St. John, St. and the parts Charles, St. James, Ascension, Assumption, Terre and Virginia Bonne, Lafourche, St. Marie, St. Martin, and Or- occupied by leans, including the city of New Orleans), Missis- were not insippi, Alabama, Florida, Georgia, South Carolina, cluded.

North Carolina, and Virginia (except the fortyeight counties designated as West Virginia, and also the counties of Berkely, Accomac, Northampton, Elizabeth City, York, Princess Ann, and Norfolk, including the cities of Norfolk and Portsmouth), and which excepted parts are for the present left precisely as if this proclamation were not issued.

And, by virtue of the power and for the purpose Death blow aforesaid, I do order and declare that all persons to slavery. held as slaves within said designated states and parts of states are and henceforth shall be free; and that the Executive Government of the United States, including the military and naval authorities 
thereof, will recognize and maintain the freedom of said persons.

And I hereby enjoin upon the people so declared Encourageto be free, to abstain from all violence, unless in ment. necessary self-defence; and I recommend to them that in all cases, when allowed, they labour faithfully for reasonable wages.

And I further declare and make known that such Acknowledgpersons of suitable condition will be received into ment of the armed service of the United States, to garrison troops. forts, positions, stations, and other places, and to man vessels of all sorts in said service.

And upon this act, sincerely believed to be an act of justice, warranted by the Constitution, upon military necessity, I invoke the considerate judg- At the outset ment of mankind and the gracious favour of Al- refused to mighty God. accept the negroes as

In testimony whereof, I have hereunto set my "prisoners name, and caused the seal of the United States to of war." In be affixed. consequence the President issued, July

Done at the city of Washington, this first day of 30 th, '63, January, in the year of our Lord one thou- for every [L. s.] sand eight hundred and sixty-three, and of Union solthe Independence of the United States the in violation eighty-seventh.

By the President:

ABRAHam Lincoln. of war of the laws of war a rebel should be executed.

William H. Seward, Secretary of State.

\section{CONTEMPORARY EXPOSITION}

CRAVENS (1862)

Let us look for a moment at some of the results of the general and immediate emancipation of four million slaves. . . . I know that the instincts of the people are against receiving them into their midst. We feel that we are not responsible for their maintenance as they now are. We fear, notwithstanding any statutory provision we may enact, that these 
millions of enfranchised slaves will come in crowds into every community; come into competition with our white labour, and burden us with their support. It is not an imaginary fear, as the President would have us believe, but a stern reality. The few contrabands now under the care of the Government have entailed upon it immense expense. This emancipation measure seems to contemplate the bursting up of the old relations of society, that have long existed in the Southern States. . . . What sagacity can foresee the results of universal emancipation? My judgment is that the people will never consent to it.

J. A. Cravens, Speech in House of Representatives. Congressional Globe, 37th Cong., 3d Sess. Appendix, 43. December 18, 1862.

\section{THOMAS (1862)}

I have always been taught that the people is the sovereign : that these constitutions are carefully defined grants from the sovereign powers, so framed as to establish justice, and at the same time secure blessings of liberty and the protection of law even to the humblest and meanest citizen. I know, Mr. Speaker, that these are old-fashioned sentiments. Magna Charta is soiled and worm-eaten. The Bill of Rights, the muniments of personal freedom, habeas corpus, trial by jury, what are they all worth in comparison with this new safeguard of liberty, the proceeding in rem?

Were you ever in Runnymede, Mr. Speaker ? I remember going down, on a beautiful day in July, from Windsor Castle to the plain, and crossing the narrow channel of the Thames to that little island in which more than six centuries ago, in the early gray morning, those sturdy barons wrested from an unwilling king the first great charter of English freedom the germ of life of the civil liberty we have to-day. I could hardly have been more moved had I stood in the village and by the manger in which was cradled the Son of Mary and the Son of God. From the gray of that morning streamed the rays, which uplifting with the hours, coursing with the years, and keeping pace with the centuries have encircled the whole earth with the glorious light of English liberty. The liberty for which our fathers planted these commonwealths in the wilderness, for which they went through the baptism of fire and 
blood in the Revolution: which they imbedded and hoped to make immortal in the Constitution; without which the Constitution would not be worth the parchment on which it is written.

Benjamin F. Thomas, in House of Representatives, Congressional Globe. 37th Cong., 2d Sess. Appendix, 220. May 24, 1862.

\section{GRANT (1863)}

Milliken's Bend, Louisiana.

... Corps, division, and post commanders will afford all facilities for the completion of the negro regiments now organizing in this department. Commissioners will issue supplies, and quartermasters will furnish stores, on the same requisitions and returns as are required for other troops. It is expected that all commanders will especially exert themselves in carrying out the policy of the Administration, not only in organizing coloured regiments and rendering them efficient, but also in removing prejudices against them.

U. S. Grant, General Order, in Jeremiah Chaplin, Words of our Hero, Ulysses S. Grant. 9.

\section{CARPENTER (1866)}

Mr. Chase told me that at the Cabinet meeting, immediately after the battle of Antietam, and just prior to the issue of the September Proclamation, the President entered upon the business before them, by saying that "the time for the annunciation of the emancipation policy could be no longer delayed. Public sentiment," he thought, "would sustain it - many of his warmest friends and supporters demanded it - and he had promised his God that he would do it!" The last part of this was uttered in a low tone, and appeared to be heard by no one but Secretary Chase, who was sitting near him. He asked the President if he correctly understood him. Mr. Lincoln replied: "I made a solemn vow before God, that if General Lee was driven back from Pennsylvania, I would crown the result by a declaration of freedom to the slaves." . . .

In February, 1865, a few days after the passage of the "Constitutional A mendment," I went to Washington, and was received by Mr. Lincoln with the kindness and familiarity 
which had characterized our previous intereourse. I said to him at this time that $I$ was very proud to have been the artist to have first conceived of the design of painting a picture commemorative of the Act of Emancipation; that subsequent occurrences had only confirmed my own first judgment of that act as the most sublime moral event in our history. "Yes," said he, - and never do I remember to have noticed in him more earnestness of expression or manner, - " as affairs have turned, it is the central act of my administration, and the large event of the nineteenth century."

F. B. CArpenter, Six Months at the White House. 89-90.

\section{CRITICAL COMMENT}

JOHNSTON (1889)

At the beginning of the war the people and leaders of the North had not desired to interfere with slavery, but circumstances had been too strong for them. Lincoln had declared that he meant to save the Union as he best could, - by preserving slavery, by destroying it, or by destroying part and preserving part of it. Just after the battle of Antietam he issued his proelamation calling on the revolted States to return to their allegiance before the following January 1, otherwise their slaves would be declared free men. No State returned, and the threatened declaration was issued January 1, 1863. As President, Lincoln could issue no such declaration; as commander-in-chief of the armies and navies of the United States, he could issue directions only as to the territory within his lines; but the Emaneipation Proclamation applied only to territory outside of his lines.

It has therefore been debated whether the proclamation was in reality of any force. It may failly be taken as an announcement of the policy which was to guide the army, and as a declaration of freedom taking effect as the lines advanced. At all events, this was its exact effect. Its international importance was far greater. The locking up of the world's source of cotton-supply had been a general ealamity, and the Confederate Grovernment and people had steadily expected 
that the English and French Governments, or at least one of them, would intervene in the war for the purpose of raising the blockade and releasing the southern cotton. The conversion of the struggle into a crusade against slavery made intervention impossible for Governments whose peoples had now a controlling influence on their policy, and intelligence enough to understand the issue which had now been made.

Alexander Johnston, The United States, Its History and Constitution. $230,231$.

\section{NICOLAY AND HAY (1890)}

Vast as were its consequences, the act itself was only the simplest and briefest formality. It could in no wise be made sensational or dramatic. . . Those who were in the house came to the executive office merely from the personal impulse of curiosity joined to momentary convenience. His signature was attached to one of the greatest and most beneficent military decrees of history in the presence of less than a dozen persons; after which it was carried to the Department of State to be attested by the great seal and deposited among the archives of the Government. . . . Like all his reasoning, it is simple and strong, resting its authority on the war powers of the Government and its justification upon military necessity. As to the minor subtleties of interpretation or comment which it might provoke from lawyers or judges after the war should be ended, we may infer that he had his opinions, but that they did not enter into his motives of action. On subsequent occasions, while continuing to declare his belief that the proclamation was valid in law, he nevertheless frankly admitted that what the courts might ultimately decide was beyond his knowledge as well as beyond his control. . . .

For the moment he was dealing with two mighty forces of national destiny, civil war and public opinion; forces which paid little heed to theories of public, constitutional, or international law where they contravened their will and power. In fact it was the impotence of legislative machinery, and the insufficiency of legal dicta to govern or terminate the conflicts of public opinion on this identical question of slavery, which brought on civil strife. In the South slavery had taken up 
arms to assert its nationality and perpetuity; in the North freedom had risen first in mere defensive resistance; then the varying fortunes of war had rendered the combat implacable and mortal. It was not from the mouldering volumes of ancient precedents, but from the issues of the present wager of battle, that future judges of courts would draw their doctrines to interpret to posterity whether the Edict of Freedom was void or valid.

Nicoldy AND HAY, Abraham Lincoln: A History. VI. 429-430, 435-436.

\section{PIERCE (1893)}

This proclamation, followed by the later one of January 1, 1863, yields in importance to no event in American or even in modern history. It had not, indeed, the sanction of the States as a constitutional provision, or of Congress as a statute, or of a high tribunal as a rule of law. It could not perhaps have been pleaded in any court as securing the liberty of a single slave. But in its significance and effect it stands before any edict, secular or ecclesiastical, since Constantine proclaimed Christianity as the religion of the Roman world. It was the voice of a great nation, uttered in solemn form at the supreme moment of its history, pledging itself to the cause of universal freedom.

Edward L. Pierce, Memoir and Letters of Charles Sumner. IV. 66.

DUNNING (1897)

It has sometimes been said that January 1, 1863, marks the most distinct epoch in the history of the war. The Emancipation Proclamation is assumed as the dividing line between the old system and the new. This view is more appropriate to the state of affairs in the South than to that in the North. It is unquestionably true that Mr. Lincoln's decree furnished the Southern leaders with a most effective instrument for the consolidation of sentiment in the Confederacy. From that time the struggle on the part of the South was a desperate battle for existence. But in the North, on the other hand, the triumph of the radicals in securing the adoption of their policy by the President awakened feelings of apprehension among the other political factions. Mr. Lincoln admits, in his message to 
Congress in December, that the issue of the proclamation "was followed by dark aud doubtful days."

William A. Dunning, Essays on the Civil War and Reconstruction. 60,61.

MORSE (1897)

The first day of January, 1863, arrived, and no event had occurred to delay the issue of the promised proclamation. It came accordingly. By virtue of his power, as commander-inchief, . . . the President ordered that all persons held as slaves in certain States and parts of States, which he designated as being then in rebellion, should be thenceforward free, and declared that the Executive, with the army and navy, would " recognize and maintain the freedom of said persons." . .

The people at large received this important step with some variety of feeling and expression; but, upon the whole, approval seems to have far outrun the dubious prognostications of the timid and conservative class. For the three months, which had given opportunity for thinking, had produced the result which Mr. Lincoln had hoped for. It turned out that the mill of God had been grinding as exactly as always. Very many, who would not have advised the measure, now heartily ratified it. Later, after men's minds had had time to settle and the balance could be fairly struck, it appeared undeniable that the final proclamation had been of good effect; so Mr. Lincoln himself said.

John T. Morse, Jr., Abraham Lincoln. II. 130-132.

McCALL (1899)

Lincoln determined that the bravest course was the safest course, and he put emancipation as a war measure squarely before the people only a few weeks before the Congressional elections of 1862. He declared that all slaves in those rebel States which should not have submitted before January 1, 1863, " shall be then, thenceforward, and forever free." It was in the power of the Confederates to avoid the proclamation by laying down their arms. They were not compelled to continue the war. On the other hand if they were to keep on fighting indefinitely they could not expect the North to cherish their 
institution any longer. It was well that Lincoln displayed all his consummate skill as a politician in framing the issue as he did frame it, for the election was of transcendent importance. A hostile Congress meant, not merely delay and probably destruction to the emancipation policy, but it meant also reduced appropriations for the war and great encouragement to the Confederates. The Democrats accepted the issue; indeed they were anxious to raise it.

Samuel W. McCali, Thaddeus Stevens. 218-219.

FREDERIC BANCROFT (1900)

Before the proclamation of emancipation was issued, January 1, 1863, emancipation societies were forming in England; and by the time it had crossed the Atlantic all intelligent Englishmen were beginning to gain correct knowledge as to the eause of the war. January had not passed before the first waves of the anti-slavery storm in America were felt. In a few weeks more, English public opinion showed a surprising awakening. Great public meetings were held in the large cities, and famous speakers addressed audiences infused with the ardour and courage peculiar to national reform movements. The mass of labourers in mines and factories rapidly developed a bitter prejudice against the Confederacy. Impressive antislavery resolutions were passed unanimously, and addresses of eongratulation were sent to the President of the United States. As Cobden wrote to Sumner, these remarkable demonstrations of sympathy for the cause of freedom " closed the mouths of those who have been advocating the side of the South." The friends of the North felt thenceforth that they had a cause to plead.

Frederic Bancroft, Life of William H. Seward.1 II. 340-341.

\section{TARBELL (1900)}

When Congress opened on December 1, he did submit the proelamation, together with the plan for compensated emancipation whieh he had worked out. Over one-half of the message, in fact, was given to this plan.

Mr. Lincoln pleaded with Congress for his measure as he

I Copyright, 1899 and 1900, by Harper \& Brothers. 
had never pleaded before. He argued that it would "end the struggle and save the Union forever," that it would " cost no blood at all," that Congress could do it if they would unite with the executive, that the "good people" would respond and support it if appealed to.

"It is not," he said, " "Can any of us imagine better?' but, 'Can we all do better?' Object whatsoever is possible, still the question occurs, 'Can we do better?' The dogmas of the quiet past are inadequate to the stormy present. The oecasion is piled high with difficulty, and we must rise with the oceasion. As our case is new, so we must think anew and act anew. We must disenthrall ourselves, and then we shall save our country.

"Fellow citizens, we cannot escape history. We of this Congress and this Administration will be remembered in spite of ourselves. No personal significance or insignificance can spare one or another of us. The fiery trial through which we pass will light us down, in honour or dishonour, to the latest generation. We say we are for the Union. The world will not forget that we say this. We know how to save the Union. The world knows we do know how to save it. We-even we here - hold the power and bear the responsibility. In giving freedom to the slave, we assure freedom to the free-honourable alike in what we give and what we preserve. We shall nobly save or meanly lose the last, best hope of earth. Other means may succeed; this could not fail. The way is plain, peaceful, generous, just - a way which, if followed, the world will forever applaud, and God must forever bless."

IDA M. TARBeLL, Life of Abraham Lincoln. II. 122-123. 


\section{Chapter XXIII}

\section{THE RECONSTRUCTION AMENDMENTS (1865-1870)}

\section{SUGGESTIONS}

The Thirteenth Amendment was proposed by Congress Feb. 1, 1865, and declared to have been ratified by twenty-seven of the thirty-six States, Dec. 18, 1865.

The Fourteenth Amendment was proposed by Congress June 16, 1866 , and declared to have been ratified by thirty of the thirty-six States, July 28, 1868.

The Fifteenth Amendment was proposed by Congress Feb. 26, 1869, and declared to have been ratified by twenty-nine of the thirty-seven States, March 30, 1870.

With the examination of the three amendments, we reach the farthest extension of free institutions by the Teutonic race. Beginning with the liberty of the baron, set forth in Magna Charta in 1215 , the doctrine that all men are born equal in so far as rights and privileges in government are concerned was in these documents finally demonstrated and made good by law.

For Outlines and Material, see Appendix B.

\section{DOCUMENTS}

\section{Thirteenth Amendment (1865)}

Section 1. Neither slavery nor involuntary servi- American His. tude, except as a punishment for crime whereof the tory Leaflets, party shall have been duly convicted, shall exist from original within the United States, or any place subject to manuscript their jurisdiction. Rolls). Slavery forbidden

Section 2. Congress shall have power to enforce by law in this article by appropriate legislation.

Fourteenth Amendment (1868) every place under U. S. jurisdiction.

SECtion 1. All persons born or naturalized in Citizenship the United States, and subject to the jurisdiction defined by 
law. Note thereof, are citizens of the United States and of "Opinion of the State wherein they reside. No State shall make Dred Scott or enforce any law which shall abridge the priviCase. This leges or immunities of citizens of the United States;

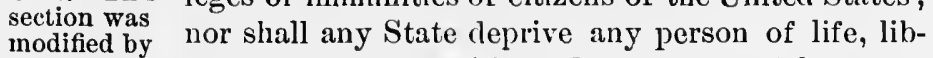
the adoption erty, or property, without due process of law; nor of the 15 th deny to any person within its jurisdiction the equal which abso- protection of the laws.

lutely took away from the State the power to exclude the negro from suffrage.

Section 2. Representatives shall be apportioned among the several States according to their respective numbers, counting the whole number of persons in each State, excluding Indians not taxed. But when the right to vote at any election for the choice of electors for President and Vice President of the United States, Representatives in Congress, the $\mathbf{E x}$ ecutive and Judicial officers of a State, or the members of the Legislature thereof, is denied to any of the male inhabitants of such State, being twentyone years of age, and citizens of the United States, or in any way abridged, except for participation in rebellion, or other crime, the basis of representation therein shall be reduced in the proportion which the number of such male citizens shall bear to the whole number of male citizens twenty-one years of age in such State.

Section 3. No person shall be a Senator or Representative in Congress, or elector of President and Vice President, or hold any office, civil or military, under the United States, or under any State, who, having previously taken an oath, as a member of Congress, or as an officer of the United States, or as a member of any State legislature, or as an executive or judicial officer of any State, to support the Constitution of the United States, shall have engaged in insurrection or rebellion against the same, or given aid and comfort to the enemies thereof. But Congress may by a vote of two-thirds of each House, remove such disability.

Section 4. The validity of the public debt of the 
United States, authorized by law, including debts Federal Debt incurred for payment of pensions and bounties for assumed. services in suppressing insurrection or rebellion Confederate shall not be questioned. But neither the United States nor any State shall assume or pay any debt or obligation incurred in aid of insurrection or rebellion against the United States, or any claim for the loss or emancipation of any slave; but all such debts, obligations and claims shall be held illegal and roid.

Section 5. The Congress shall have power to enforce, by appropriate legislation, the provisions of this article.

Fifteenth Amendment (1870) By this amendment

SECTION 1. The right of citizens of the United suffrage was States to vote shall not be denied or abridged by tial, but not the United States or by any State on account of necessarily race, colour, or previous condition of servitude. - male citizens

Section 2. The Congress shall have power to above the age enforce this article by appropriate legislation. - one years.

\section{CONTEMPORARY EXPOSITION}

\section{COFFROTH (1865)}

Mr. Speaker, I speak not to-day for or against slavery. I am contented that this much agitated question shall be adjudicated at the proper time by the people. It is my purpose to state in all candour the reasons which prompt me to give the vote I shall now soon record. The amending of our Constitution is fraught with so much importance to the American people that before it is accomplished the amendments proposed should be scrutinized with the strictest criticism. . . . The life and existence of this nation is centered in the observance and faithful execution of the powers conferred by the Constitution upon the servants of the people. ...

It is argued that this amendment is unconstitutional; that the Congress of the United States has no legal authority to propose this amendment, nol have the states in ratifying it the consti- 
tutional power to destroy or interfere with the right of property. Learned gentlemen of this House differ on this subject. The Constitution itself provides the remedy by which all these differences of opinion can be legally adjudieated. (See Sec. 2 of Art. 3 of the Constitution.) . . . I have voted for every peace resolution in this House. My heart yearns for peace . . . and if by my vote this amendment is submitted to the States, and it brings this war to a close, I will ever rejoice at the vote I have given.

A. H. Cofrnoth, Congressional Globe, 38 Cong. 2d Sess. 523. Jan. 31, 1865.

BROWN (1865)

It is mischievous in so far as it would tie the hands of the President, in so regulating the mode of abolishing slavery as not to precipitate upon the country three million ignorant and debased negroes, without the slightest preparation for liberty or power on the part of the Goverument, by a system of apprenticeship or otherwise to require them to labour. . . .

Fngland, in emancipating the slaves on her islands, not only established a system of apprenticeship, but compensated those who lost. It is no answer that slavery is immoral : individuals, upon the faith of laws which recognized rights in negro labour, have invested their property in such rights. When the Government sees fit to change its poliey and destroy its rights, it owes compensation. Of course compensation is due only to loyal owners.

It is a dangerous abuse of the power of amendment conferred by the Constitution.

J. S. Brown, in House of Representatives, Congressional Globe, 38 Cong. 2 d Sess. 527. Jan. 31, 1865.

\section{BLAINE (1886)}

The proposed Constitutional amendment was brought before the House on the 6th of January by Mr. Ashley of Obio, upon whose motion to reconsider the adverse vote of the preceding session, the question continued to have a parliamentary status. He made a forcible speech in support of the amendment, but the chief value of his work did not consist in speaking, but in his watchful care of the measure, in the quick and intuitive judgment with which he discerned every man on the Demo- 
cratic side of the House who felt anxious as to the vote he should give on the moinentous question, and in the pressure which he brought to bear upon him from the best and most influential of his constituents. The issue presented was one that might well make thoughtful men pause and consider. The instant restoration to four millions of human beings of the God-given right of freedom so long denied them, depended upon the vote of the House of Representatives. It addressed itself to the enlightened judgment and to the Christian philanthropy of every member. Each one had to decide for himself whether so far as lay in the power of his own vote he would give liberty to the slave, or forge his fetters anew. The constitutional duty of not interfering with slavery in the States could not be pleaded at the bar of conscience for an adverse vote. There was no doubt that under the terms of the Constitution such interference was unwarranted. But this was a question of changing the Constitution itself so as to confer upon Congress the express power to enlarge the field of personal liberty and make the Republic free indeed. It came therefore as an original and distinct question whether millions of people with their descendants for all time should be doomed to slavery or gifted with freedom. . . .

The vote was 119 yeas to 56 nays - more than the constitutional two-thirds. When the announcement was made, the Speaker became powerless to preserve order. The members upon the Republican side sprang upon their seats cheering, shouting, and waving hands, bats, and canes, while the spectators upon the floor and in the galleries joined heartily in the demonstrations. $\therefore$. .

The great act of Liberation, so far as Congress conld control it, was complete. The amendment was at once submitted to the States, and by official proclamation of December 18,1865 , - less than eleven months after Congress had spoken, - the Secretary of State announced that it had been ratified by the Legislatures of twenty-seven States and was a part of the Constitution. The result was attained by the united action of one party and the aid of a minority of the other party. The cooperation of the Democratic members had gained for the cause of emancipation a whole year. The action was of transcend- 
ent importance - lofty in conception, masterful in execution. Slavery in the United States was dead. To succeeding and not distant generations its existence in a Republic, for three-quarters of a century, will be an increasing marvel. . . .

The success of reconstruction in the South carried with it the ratification of the Fourteenth Amendment by the requisite number of States. 'The result was duly certified by Mr. Seward as Secretary of State, on the twenty-eighth day of July, 1868, and the Amendment was thenceforward a part of the organic law of the nation. It had been carried, from tirst to last, as a party measure - unanimously supported by the Republicans, unanimonsly opposed by the Democrats. Its grand and beneficent provisions failed to attract the vote of a single Democratic member in any State Legislature in the whole Union. . . . It is very seldom in the history of political issues, even when partisan feeling is most deeply developed, that so absolute a division is found as was recorded upon the question of adopting the Fourteenth Amendment. It has not been easy in succeeding year's to comprehend the deep-seated, all-pervading hostility of the Democratic party to this great measure. Even on the Thirteenth Amendment containing the far more radical proposition to abolish slavery, a few Democrats, moved by philanthropic motives, broke from the restraint of party and honoured themselves by recording their rotes on the side of humanity and justice; but on the Fourteenth Amendment the line of Democratic hostility in Nation and in State was absolutely unbroken.

It seems incredible that Democrats can be satisfied with the record made by their party on this most grave and important question. Every one of the many objects aimed at in the Fourteenth Amendment is founded upon a basis of justice, of liberty, of an enlarged and enlightened nationality. Its minor provisions might be regarded as temporary in their nature, but its leading provisions are permanent and are essential to the vitality of a true republic. Even those which may be held as temporary deeply affect more than one generation of American citizens, and are of themselves sufficiently important to justify a great struggle for their adoption. . . .

Suffrage by the Fifteenth Amendment was made impartial, 
but not necessarily universal, to male citizens above the age of twenty-one years.

The adoption of the Fifteenth Amendment seriously modified the effect and potency of the second section of the Fourteenth Amendment. Under that section a State could exclude the negro from the right of suffrage, if willing to accept the penalty of the proportional loss of representation in Congress, which the exclusion of the coloured population from the basis of apportionment would entail. But the Fifteenth Amendment took away absolutely from the State the power to exelude the negro from suffrage, and therefore the second section of the Fourteenth Amendment can refer only to those other disqualifications never likely to be applied, by which a State might lessen her voting population by basing the right of suffrage on the ownership of real estate, or on the possession of a fixed income, or upon a certain degree of education, or upon nativity, or religious creed. It is still in the power of the States to apply any one of these tests, or all of them, if willing to hazard the penalty prescribed in the Fourteenth Amendment. But it is not probable that any one of these tests will ever be applied. Nor were they seriously taken into consideration when the Fourteenth Amendment was proposed by Congress. Its prime object was to correct the wrongs which might be enacted in the South, and the correction proposed was direct and unmistakable; viz., that the Nation would exclude the Negro from the basis of apportionment wherever the State should exclude him from the right of suffrage.

When therefore the nation by subsequent change in its Constitution declared that the State shall not exclucle the negro from the right of suffrage, it neutralized and surrendered the contingent right before held, to exclude him from the basis of apportionment. Congress is thus plainly deprived by the Fifteenth Amendment of certain powers over representation in the South, which it previously possessed under the provisions of the Fourteenth Amendment. Before the adoption of the Fifteenth Amendment, if a State should exclude the negro from suffrage, the next step would be for Congress to exclude the negro from the basis of apportionment. After the adoption of the Fifteenth Amendment, if a State should exclucle the negro 
from suffrage, the next step would be for the Supreme Court to declare that the act was unconstitutional, and therefore null and void. The essential and inestimable value of the Fourteenth Amendment still remains in the three other sections, and preëminently in the first section.

James G. Blaine, Twenty Years of Congress. I. 536-539; II. 309, 418.

\section{CRITICAL COMMENT}

LOWELL (1866)

But under the Johnsonian theory of reconstruction, we shall leave a population which is now four millions not only taxed without representation, but doomed to be so forever without any reasonable hope of relief. The true point is not as to the abstract merits of universal suffrage (though we believe it the only way toward an enlightened democracy and the only safeguard of popular government), but as to whether we shall leave the freedmen without the only adequate means of self-defence. And however it may be now, the twenty-six States certainly were the Union when they accepted the aid of these people and pledged the faith of the government to their protection. Jamaica, at the end of nearly thirty years since emancipation, shows us how competent former masters are to accomplish the elevation of their liberated slaves, even though their own interests would prompt them to it. Surely it is a strange plea to be effective in a democratic country, that we owe these people nothing because they cannot help themselves; as if governments were instituted for the care of the strong only. The argument against their voting which is based upon their ignorance strikes us oddly in the mouths of those whose own hope of votes lies in the ignorance, or, what is often worse, the prejudice of the voters. Besides, we do not demand that the seceding States should at once confer the right of suffrage on the blacks, but only that they should give them the same chance to attain it, and the same inducement to make themselves worthy of it, as to every one else.

James Russell I.oweld, Prose Works. V. 303, 304 


\section{COOLEY (1880)}

The Last Three Amenduents. - In the lapse of ninety years, a stage in political history is reached in which the fears and anxieties of the people took a new direction. In rapid succession one State after another in one-third of the Union had rejected and thrown off the federal authority, and it had only been restored through a war prosecuted on both sides with great bitterness and with enormous destruction of life and property. ... It had been found in vain that the federal authorities held, and the federal courts decided, that under the Constitution a State had no right to withdraw from the Union; it was undeniable that for a time certain of the States had succeeded in severing their relations and setting up a new government; and though the federal authority bad demonstrated that it had, under the Constitution, ample power for self-defence and protection, it was deemed wise and prudent to require the States to surrender the institution that was the immediate occasion of the civil war, as well as the power to deal unjustly and partially with classes of the people against whom there might be jealousies, prejudices, or antipathies, growing ont of the struggle through which the country had passed, or out of some of the antecedent or concomitant circumstances. While, therefore, the first amendments were for the purpose of keeping the central power within due limits, at a time when the tendency to centralization was alarming to many persons, the last were adopted to impose new restraints on State sovereiguty, at a time when State powers had nearly succeeded in destroying the national sovereignty.

Thomas M. Cooley, Constitutional Law. 208-210.

BRYCE (1896)

The fourth group is the only one which marked a political crisis and registered a political victory. It comprises three amendments (XIII., XIV., XV.), which forbid slavery, define citizenship, secure the suffrage of citizens against attempts by States to discriminate to the injury of particular classes, and extend Federal protection to those citizens who may suffer from the operation of certain kinds of unjust State laws. These 
three amendments are the outcome of the War of Secession, and were needed in order to confirm and secure for the future its results. The requisite majority of States was obtained under conditions altogether abnormal, some of the lately conquered States ratifying while actually controlled by the Northern armies, others as the price which they were obliged to pay for the re-admission to Congress of their senators and representatives. The details belong to history: all we need here note is that these deep-reaching, but under the circumstances perhaps unavoidable, changes were carried through not by the free will of the peoples of three-fourths of the States, but under the pressure of a majority which had triumphed in a great war, and used its command of the National government and military strength of the Union to effect purposes deemed indispensable to the reconstruction of the Federal system.

James Bryce, The American Commonwealth.1

256.

DUNNING (1897)

They found a constitutional basis for the law in the Thirteenth Amendment. Slavery and involuntary servitude were by that article prohibited; and, by the second section, Congress, and not the state legislatures, was authorized to enforce the prohibition. What constituted slavery and inroluntary servitude, in the sense of the amendment? Slavery and liberty, it was answered, are contradictory terms. If slavery is prohibited, civil liberty must exist. But civil liberty consists in natural liberty, as restrained by human laws for the advantage of all, provided that these restraints be equal to all. A statute which is not equal to all is an encroachment on the liberty of the deprived persons, and subjects them to a degree of servitude. It is the duty of Congress, therefore, to counteract the effects of any such state laws. Thus the constitutionality of the bill was maintained.

- . The content of the proposed Fourteenth Amendment marks very accurately the progress thit had been made by the spring of 1866 in ideas as to the extent to which reconstruction should go. In the first section, the desire of the conservative Republicans to put the civil rights of the negroes under the protection of the United States was gratified. The fourth

1 Copyright, 1896, by the Macmillan Co. 
guaranteed the financial integrity of the government, and thus satisfied those who feared some assertion of state rights that might legalize debts incurred in opposition to the national authority. 'These two provisions constituted the limitations upon the powers of the states that were generally recognized as unavoidable consequences of the war. The second section of the amendment dealt with matters upon which opinion in the dominant party was far from certain and harmonious. It embodied a very clumsy and artificial solution of the suffrage problem. The alternative presented to the states, of enfranchising the blacks or losing proportionally in representation, was a mere temporary compromise between two party factions. It was the most that the friends of negro suffrage could secure at this stage of the process; but there was no indication that they would be satisfied with this. The third section of the amendment was merely incidental to the conflict between Congress and President Johnson. The President's very free exercise of the pardoning power interfered with the progress of the legislature's policy, and no method of checking this interference seemed so feasible as a constitutional amendment. As a whole, the amendment was tentative. It betokened a longing for a definite settlement of the two great questions of the day, tempered by dread of an adverse public sentiment.

... The "fundamental conditions" which afforded the only basis for Congressional maintenance of negro suffrage in the restored states were regarded by a large majority of constitutional lawyers in both parties as of doubtful validity. Under the circumstances a further amendment to the constitution was the only resort that could be depended upon for the end desired. Hence the Fifteenth Amendment was, after a long and ardent discussion of the whole field of political philosophy, sent to the state legislatures by resolution finally passed February 26,1869 .

. . On March 30, 1870, the ratification of the Fifteenth Amendment had been proclaimed, and just two months later the first enforcement act became law. By the policy thus expressed the issue was definitely made up which ended in the undoing of the reconstruction. Seven unwholesome years were required to demonstrate that not even the government which 
had quelled the greatest rebellion in history could maintain the freedmen in both security and comfort on the necks of their former masters. The demonstration was slow, but it was effective and permanent.

William A. Dunwing, Essays on the Civil War and Reconstruction. 93, 252, passim.

\section{MCLAUGHLIN (1899)}

It will be remembered that the Emancipation Proclamation declared free all slaves within those parts of the South then in open rebellion. This was confessedly a war measure - like any other confiscation of property, an act of war. It did not destroy slavery in the States not in rebellion. Moreover, some persons believed that the President had exceeded his authority in issuing such a proclamation. In the early part of 1864 a vote on the question of submitting a constitutional amendment abolishing slavery everywhere was taken into Congress. The necessary two-thirds vote could not be secured in the House, though the Senate passed the measure by a large majority. After the election, carried by the Republicans on a distinetly anti-slavery platform, abolition assumed new strength. The President in his annual message advocated the adoption of the amendment. A great debate in the House followed. The vote was one hundred and nineteen ayes to fifty-six noes - seven more than the required two-thircls. In the homely, truthful phrase of Lincoln, the "great job" was ended. . . .

The principle of the ordinance of 1787 was, in almost the exact words of that document, made applicable to the whole Union; the great curse that had separated the American people into two bitterly hostile sections was to be cast aside forever. The hopes of the future were for reorganization, a re-establishment of sympathy and fellow-feeling between North and South, now that the canse of enmity and division was no more. As Lincoln pointed out, the amendment meant the "maintenance" of the Union. . . .

It was next determined to put the Civil Rights Bill into the form of a constitutional amendment, where its principles would be permanent and safe from violation. The Fourteenth Amendment was therefore agreed upon and offered to the States (June, 
1866), for adoption. . . . It declared that no State should make or enforce any law abridging the "privileges or immunities of citizens of the United States," or deprive any person of "life, liberty or property without due process of law," or deny to any person "the equal protection of the laws." The Republicans saw that by the freeing of the blacks they had actually increased the political strength of the Southern States, because the threefifths rule would no longer apply, but all the negroes would be counted in determining the representative population. Some were desirous of giving the negroes the suffrage immediately by National act. Others hesitated. All, however, desired to prevent the Southern States from reaping this political advantage from emancipation, unless they allowed the blacks to vote. It was therefore decided that if the negroes were not given the suffrage by a State voluntarily, they should not be counted in determining the basis of representation. For these reasons the second section of the Fourteenth Amendment was added. . . .

Such was the Fourteenth Amendment, by far the greatest change made in the Constitution, since its adoption. There was some difficulty, as we shall see, in securing its ratification, the Southern States refusing to accept it; two years passed before it was finally ratified (1868), but we may notice at this time how it modified the Constitution when once it became a part of the fundamental law. Before this amendment was passed the subject of suffrage was solely a State affair, as long as the State had a "republican form of government." So, too, the State had complete control over its citizens and could be as tyrannical as it saw fit, provided that it did not interfere with the relations between a person and the National Government or violate the few express prohibitions in the National Constitution. By this amendment the nation intervened to protect the citizens of the State against unjust legislation or action of a State. 'Thus it will be seen the situation had entirely altered' from what it was in 1788-90.

In 1869 the Fifteenth Amendment was submitted to the States for adoption. It declared: "The right of citizens of the United States to vote shall not be denied or abridged by the United States or by any State on account of race, colour, or 
previous condition of servitude." Secretary Fish announced, March 30,1870 , that it had "become valid to all intents and purposes, as part of the Constitution of the Uniter States."

The acceptance of the Fifteenth Amendment as part of the fundamental law of the nation did not do away with the troubles .and distress that grew out of the rebellion. The corruption of the carpet-bag governments, built on negro suffrage, was proof enough that slavery had been a poor schoolmaster for freedom.

Andrew C. McLaughuin, History of the American Nation. 463-483.

\section{HART (1899)}

So far as the existence of slavery went, the Thirteenth Amendment, declared to be in force in December, 1865, was a constitutional guarantee which superseded the revocable abolition acts of the States reconstructed during that year; and it took out of the list of conditions which might be imposed upon the States an acknowledgment of the freedom of the former slaves; it superseded also the special conditions of the amnesty proclamations of Lincoln and Johnson. There still remained a necessity for statutes or constitutional amendments to define the judicial and other civil rights of the negro. . . .

During 1865 both the legal and the economic status of the negroes were confused and unsatisfactory. . . .

As soon as it became evident that Johnson had no interest in negro suffrage, and was willing to reinstate by his pardoning power a large proportion of those who had been concerned in the rebellion, Chase [Salmon P. Chase] found himself separated from the President, who no longer invited an expression of his opinion. At the same time his friends in the South assured him that, without protection from the United States, the Union men would be completely overborne and the freedman in danger. ...

Chase's sympathy now began to turn towards the congressional plan. . . This was a legislative reversal of whatever was left of the Dred Scott decision. . . .

The act was certain to arouse the opposition of the South, and was itself liable to repeal. It seemed therefore desirable to put its provisions into a constitutional amendment, which 
would forever protect the rights of the negroes and which at the same time would take out of the hands of the President the restoration of former rebels to their political status. . . .

The Southern States duly paid the price of their readmission by ratifying the Fourteenth Amendment, and from 1868 they were gradually allowed to reoccupy seats in Congress. . . . As might have been expected, so soon as the Southern States were again admitted to seats in Congress there was a tendency in the South to put an end by violence to negro suffrage; hence Congress passed a statute, the so-called Civil Rights Bill, under the Fourteenth and Fifteenth Amendments, to protect the negroes.

Albert Bushnell Hart, Salmon Portland Chase. 335, 381. 


\section{CHAPTER XXIV}

\section{LIBERTY IN UNITED STATES COLONIES AND DEPENDENCIES (1898-1899)}

\section{SUGGESTIONS}

These documents contain suggestions as to the prospective policy of government in the newly acquired territorial possessions of Cuba, Porto Rico, and the Philippine Islands.

The critical comment which follows must of necessity become in a few years a part of the contemporary exposition. It needs an historical perspective, which the future alone can give, for the proper discussion of these documents.

But, as the making of history is as important a study as the chronicles of the past, the student should look at present issues with keen interest. He must appreciate that to-day's events belong to a succession of conditions in a general movement of progress; from whatever political point of view he approaches the subject he will find these historical conditions the same.

Out of the vast amount of oratory and writing for and against the present policy of the administration, a few masters of constitutional history have been chosen to give expression in criticism.

\section{DOCUMENTS}

Extracts from President McKinley's Annual Message, Dec. 5, 1898

Messages of In the message of April 11, 1898, I announced the President, that with this last overture in the direction of imX. 163-176. mediate peace in Cuba and its disappointing reception by Spain the effort of the Executive was brought to an end. I again reviewed the alternative courses of action which had been proposer, concluding that the only one consonant with international policy and compatible with our firm-set historical traditions was intervention as a neutral to 
stop the war and check the hopeless sacrifice of life, even though that resort involved " hostile constraint upon both the parties to the contest, as well to enforce a truce as to guide the eventual settlement." The grounds justifying that step were the interests of humanity, the duty to protect the life and property of our citizens in Cuba, the right to check injury to our commerce and people through the devastation of the islaud, and, most important, the need of removing at once and forever the constant menace and the burdens entailed upon our Government by the uncertainties and perils of the situation caused by the unendurable disturbance in Cuba. I said:

"The long trial has proved that the object for which Spain has waged the war cannot be attained. The fire of insurrection may flame or may smoulder with varying seasons, but it has not been and it is plain that it cannot be extinguished by present methods. The only hope of relief and repose from a condition which can no longer be endured is the enforced pacification of Cuba. In the name of humanity, in the name of civilization, in behalf of endangered American interests which give us the right and the duty to speak and to act, the war in Cuba must stop."

In view of all this the Congress was asked to By the authorize and empower the President to take Mressage of measures to secure a full and final termination of April 11, hostilities between Spain and the people of Cuba and to secure in the island the establishment of a stable government, capable of maintaining order and observing its international obligations, insuring peace and tranquillity and the security of its citizens as well as our own, and for the accomplishment of those ends to use the military and naval forces of the United States as might be necessary, with added authority to continue generous relief to the starving people of Cuba.

The response of the Congress, after nine rlays of 
earnest deliberation, during which the almost unanimous sentiment of your body was developed on every point save as to the expediency of coupling the proposed action with a formal recognition of the Republic of Cuba as the true and lawful government of that island - a proposition which failed of adoption - the Congress, after conference, on the 19th of April, by a vote of 42 to 35 in the Senate and 311 to 6 in the House of Representatives, passed the memorable joint resolution declaring -

Cuban Inde- " "First. That the people of the island of Cuba are, pendence. and of right ought to be, free and independent.

"Second. That it is the duty of the United States Duty of the United States. to demand, and the Government of the United States does hereby demand, that the Government of Spain at once relinquish its authority and government in the island of Cuba and withdraw its land and naval forces from Cuba and Cuban waters.

Constitution,

"Third. That the President of the United States Art. ii. sect. be, and he bereby is, directed and empowered to use $2, \S 1$.

Attitude of the United States towards Cuba. the entire land and naval forces of the United States and to call into the actual service of the United States the militia of the sereral States to such extent as may be necessary to carry these resolutions into effect.

"Fourth. That the United States hereby disclaims any disposition or intention to exercise sovereignty, jurisdiction, or control over said island except for the pacification thereof, and asserts its determination when that is accomplished to leave the government and control of the island to its people."

This resolution was approved by the Executive on the next day, April 20. . . .

After the instruction reached General Woodford on the morning of April 23, but before he could present it, the Spanish minister of state notified him that upon the President's approval of the joint resolution the Madrid Government, regarding the 
act as "equivalent to an evident declaration of war," had ordered its minister in Washington to withdraw, thereby breaking off diplomatie relations between the two countries and ceasing all oflicial eommunication between their respective representatives. Diplomatic cation between their respective representatives. relations General Woodford thereupon demanded his pass- with Spain ports and quitted Madrid the same day.

Spain having thus denied the demand of the United States and initiated that complete form of rupture of relations which attends a state of war, the executive powers authorized by the resolution were at once used by me to meet the enlarged contingency of actual war between sovereign states.

I do not discuss at this time the Government or the future of the new possessions which will come to us as the result of the war with Spain. Such discussion will be appropriate after the treaty of peace shall be ratified. In the meantime and until the Congress has legislated otherwise it will be my duty to continue the military governments which have existed since our occupation and give to the people security in life and property and encouragement under a just and beneficent rule.

As soon as we are in possession of Cuba and have pacified the island it will be necessary to give puture aid and direction to its people to form a government for themselves. This should be undertaken at the earliest moment consistent with safety and assured success. It is important that our relations with this people shall be of the most friendly character and our commercial relations close and reciprocal. It should be our duty to assist in every proper way to build up the waste places of the island, encourage the industry of the people, and assist them to form a government which shall be free and independent, thus realizing the best aspirations of the Cuban people.

Spanish rule must be replaced by a just, benevo- life. point.

Immediate effort to improve sanitary, educational, and municipal 
lent, and humane government, created by the people of Cuba, capable of performing all international obligations, and which shall encourage thrift, industry, and prosperity and promote peace and good will among all of the inhabitants, whatever may have been their relations in the past. Neither revenge nor passion should have a place in the new government. Until there is complete tranquillity in the island and a stable government inaugurated military occupation will be continued.

Extracts from President McKinley's Annual Message, Dec. 5, 1899

Congressional Record, 56 Cong. 1 Sess., 29-36, passim.
My Annual Message of last year was necessarily devoted in great part to a consideration of the Spanish war and of the results it wrought and the conditions it imposed for the future. I am gratified to announce that the treaty of peace has restored friendly relations between the two powers. Effect has been given to its most important provisions. The evacuation of Porto Rico having already been accomplished on the 18th of October, 1898, nothing remained necessary there but to continue the provisional military control of the island until the Congress should enact a suitable government for the ceded territory. Of the character and scope of the measures to that end I shall treat in another part of this Message.

The withdrawal of the authority of Spain from the island of Cuba was effected by the 1st of January, so that the full re-establishment of peace found the relinquished territory held by us in trust for the inhabitants, maintaining, under the direction of the Executive such government and control therein as should conserve public order, restore the productive conditions of peace so long disturbed by the instability and disorder which prevailed for the greater part of the preceding three decades, and build up that tranquil development of the do- 
mestic state whereby alone can be realized the high purpose, as proclaimed in the joint resolution adopted by the Congress on the 19th of April, 1898 , by which the United States disclaimed any disposition or intention to exercise sovereignty, jurisdiction or control over Cuba, except for the This pledge pacification thereof, and asserted its determination, significance. when that was accomplished to leave the government and control of the island to its people. The pledge contained in this resolution is of the highest honorable obligation and must be kept.

I believe thit substantial progress has been made in this direction. All the administrative measures Reforms beadopted in Cuba have aimed to fit it for a regen-gun. erated existence by enforcing the supremacy of law and justice; by placing wherever practicable the machinery of arlministration in the hands of the inhabitants; by instituting needed sanitary reforms ; by spreading education; by fostering industry and trade ; by inculeating public morality, and, in short, by taking every rational step to aid the Cuban people to attain to that plane of self-conscions respect and self-reliant unity which fits an enlightened community for self-government within its own sphere, while enabling it to fulfil all outward obligations.

This nation has assumed before the world a grave responsibility for the future good government of Cuba. We have accepted a trust the fulfilment of which calls for the sternest integrity of purpose and the exercise of the highest wisdom. The new Cuba Cuba's future yet to arise from the ashes of the past must needs prosperity. be bound to us by ties of singular intimacy and strength if its enduring welfare is to be assured. Whether those ties shall be organic or conventional, the destinies of Cuba are in some rightful form and manner irrevocably linked with our own, but how and how far is for the future to determine in the ripeness of events. Whatever be the ontcome, we 
must see to it that free Cuba be a reality, not a name; a perfect entity, not a hasty experiment bearing within itself the elements of failure. Our mission, to accomplish which we took up the wager of battle, is not to be fulfilled by turning adrift any loosely framed commonwealth to face the vicissitudes which too often attend weaker states whose natural wealth and abundant resources are offset by the incongruities of their political organization and the recurring occasions for internal rivalries to sap their strength and dissipate their energies. The greatest blessing which can come to Cuba is the restoration of her agricultural and industrial prosperity, which will give employment to idle men and re-establish the pursuits of peace. This is her chief and immediate need. . . .

The future government of the Philippines rests with the Congress of the United States. Few

Congress to be held responsible for government in the Philippines. graver responsibilities have ever been confided to us. If we accept them in a spirit worthy of our race and our traditions, a great opportunity comes with them. The islands lie under the shelter of our flag. They are ours by every title of law and equity. They cannot be abandoned. If we desert them we leave them at once to anarchy and finally to barbarism. We fling them, a golden apple of discord, among the rival powers, no one of which could permit another to seize them unquestioned. Their rich plains and valleys would be the scene of endless strife and bloodshed. The advent of Dewey's fleet in Manila Bay instead of being, as we hope, the dawn of a new day of freedom and progress, will have been the beginning of an era of misery and violence worse than any which has darkened their unhappy past. The suggestion has been made that we could renounce our anthority over the islands and, giving them independence, could retain a protectorate over them. This proposition will not be found, I am 
sure, worthy of your serious attention. Such an Constitution, arrangement would involve at the outset a cruel Art. i. sect. breach of faith. It would place the peaceable and $8, \S 11$. loyal majority, who ask nothing better than to accept our authority, at the mercy of the minority of armed insurgents. It would make us responsible for the acts of the insurgent leaders and give us no power to control them. It would charge us with the task of protecting them against each other and defending them against any foreign power with which they choose to quarrel. In short, it would take from the Congress of the United States the power of declaring war and vest that tremendous prerogative in the Tagal leader of the hour.

It does not seem desirable that I should recommend at this time a specific and final form of goverument for these islands. When peace shall be restored, it will be the duty of Congress to construct a plan of government which shall establish and maintain freedom and order and peace in the Philippines. The insurrection is still existing, and when it terminates further information will be required as to the actual condition of affairs before inaugurating a permanent scheme of civil government. . . .

No effort will be spared to build up the waste Future deplaces desolated by war and by long years of mis- velopment government. We shall not wait for the end for the strife to begin the beneficent work. We shall con- Islands. tinue, as we have begun, to open the schools and the churches, to set the courts in operation, to foster industry and trade and agriculture, and in every way in our power to make these people whom Providence has brought within our jurisdiction feel that it is their liberty and not our power, their welfare and not our gain, we are seeking to enhance. Onr flag has never waved over any community but in blessing. I believe the Filipinos will soon recognize the fact that it has not lost its gift 
of benediction in its world-wide journey to their shores. ...

The time is ripe for the adoption of a temporary form of government for this island [Porto Rico]. ...

Porto Rican policy.

Removal of all military authority.

Local self-

The system of civil jurisprudence now adopted by the people of this island is described by competent lawyers who are familiar with it, as thoroughly modern and scientific, so far as it relates to matters of internal business, trade production, and social and private right in general. The cities of the island are governed under charters which probably require very little or no change. So that with relation to matters of local concern and private right, it is not probable that much, if any, legislation is desirable; but with reference to public administration and the relations of the island to the Federal Government, there are many matters which are of pressing urgency....

It is desirable that the government of the island under the law of belligerent right, now maintained through the Executive Department, should be superseded by an administration entirely civil in its nature. For present purposes I recommend that Congress pass a law for the organization of a temporary government, which shall provide for the appointment by the President, subject to confirmation by the Senate, of a governor and such other officers as the general administration of the island may require, and that for legislative purposes upon subjects of a local nature not partaking of a Federal character, a legislative council, composed partly of Porto Ricans and partly of citizens of the United States, shall be nominated and appointed by the President, subject to confirmation by the Senate, their acts to be subject to the approval of the Congress or the President prior to going in to effect. In the municipalities and other local subdivisions I government. recommend that the principle of local self-govern- 
ment be applied at once, so as to enable the intelligent citizens of the island to participate in their own government and to learn by practical experience the duties and requirements of a self-contained and self-governing people. I have not thought it wise to commit the entire government of the island to officers selected by the people, because I doubt whether in habits, training and experience they are such as to fit them to exercise at once so large a degree of self-government; but it is my judgment and expectation that they will soon arrive at an attainment of experience and wisdom and self-control that will justify conferring upon them a much larger participation in the choice of their insular officers.

The fundamental requirement for these people Racial charas for all people, is education. The free school- acteristics to house is the best preceptor for citizenship. In the be considintroduction of modern educational methods care, however, must be exercised that changes be not made too abruptly and that the history and racial peculiarities of the inhabitants shall be given duc weight. Systems of education in these new possessions founded upon common-sense methods, adapted to existing conditions and looking to the Good govadapted to existing conditions and looking to the ernment; future moral and industrial advancement of the civil rights. people, will commend to them in a peculiarly effective manner the blessings of free government.

The love of law and the sense of obedience and submission to the lawfully constituted judicial tribunals are embedded in the hearts of our people, and any violation of these sentiments and disregard of their obligations justly arouses public condemnation. 'The guarantees of life, liberty, and of civil rights should be faithfully upheld; the right of trial by jury respected and defended. 


\section{CONTEMPORARY EXPOSITION}

PRESIDENT MCKINLEY (1899)

We have now ended the war with Spain. The treaty has been ratified by the votes of more than two-thirds of the Senate of the United States and by the judgment of vine-tentbs of its people. No nation was ever more fortunate in war or more honourable in its negotiations in peace. Spain is now eliminated from the problem. It remains to ask what we shall now do. I do not intrude upon the duties of Congress or seek to anticipate or forestall its action. I only say that the treaty of peace, honourably secured, having been ratified by the United States, and, as we confidently expect, shortly to be ratified in Spain, Congress will have the power, and I am sure the purpose, to do what in good morals is right and just and humane for these peoples in distant seas.

It is sometimes hard to determine what is best to do, and the best thing to do is oftentimes the hardest. The prophet of evil would do nothing because he flinches at sacrifice and effort, and to do nothing is easiest and involves the least cost. On those who have things to do there rests a responsibility which is not on those who have no obligations as doers. If the doubters were in a majority, there would, it is true, be no labour, no sacrifice, no anxiety and no burden raised or carried; no contribution from our ease and purse and comfort to the welfare of others, or even to the extension of our resources to the welfarc of ourselves. There would be ease, but alas! there would be nothing done.

But grave problems come in the life of a nation, howerer much men may seek to avoid them. They come without oul' seeking; why, we do not know, and it is not always given us to know; but the generation on which they are forced cannot avoid the responsibility of honestly striving for their solution. We may not know precisely how to solve them, but we can make an honest effort to that end, and if made in conscience, justice and honor it will not be in vain.

The future of the Philippine Islands is now in the hands of the American people. Until the treaty was ratified or rejected 
the Executive Department of this government could only preserve the peace and protect life and property. . . .

I have no light or knowledge not coinmon to my countrymen. I do not prophesy. The present is all absorbing to me, but I cannot bound my vision by the blood-stained trenches around Manila, where every red drop, whether from the veins of an American soldier or a misguided Filipino, is anguish to my heart; but by the hroad range of future years, when that group of islands, under the impulse of the year just passed, shall have become the gems and glories of those tropical seas; a land of plenty and of increasing possibilities; a people redeemed from savage indolence and habits, devoted to the arts of peace, in touch with the commerce and trade of all nations, enjoying the blessings of freedom, of civil and religious liberty, of education and of homes, and whose children and children's children shall for ages hence bless the American Republic because it emancipated and releemed their fatherland and set them in the pathway of the world's best civilization.

William McKintev, Speesh delivered at the Home Market Club, in Boston Herald, February 17, 1899.

\section{SECRETARY LONG (1899)}

But, on the other hand, is the view held, I think, by the great majority of our people that we cannot thus easily, having once put our hands to the plough, look back, and that events not within our control have brought us to responsibilities which we cannot disregard and let alone, but which we must face and mect. The matter is one of great moment. I most heartily wish it had never confronted us. I wish the world would kindly let up for a while and not move so fast. I wish, also, that youth would stay. I would rather be a boy again than to be Secretary of the Navy, as I am, or President of the United States, as of course I could be if I would yield to the solicitations of my friends and accept the office. But I think it is a mistake to say that it is heyoul the ability of the American people to deal with a problem with which other nations have successfully dealt, or that it is a harder problem than many problems which are upon us already.

The problem of the immense accumulations of wealth; the 
municipal problem of our great cities, soon gathering within their limits more than half the population of the country; the problems of capital and labor; the problems of social crimes, intemperance and political integrities, are even harder and fraught with graver dangers. Indeed, I am not sure that this new friction in the far-off tropics may not be, when applied to these older maladies in the body politic, a sort of what the physicians call a counter-irritant - an ontlet for the pent-up fevers now in the national blood.

There are those who regard every new crisis as what they call "the beginning of the end." But this phrase is like the foolish nurse's cry of "ghost" to a child. The beginning of the end was long ago - at the very birth of the Republic. God has so ordered the laws of growth that no life, of plant, or man, or nation, works out its destiny and bears its fruit except by ripening to its completion. First the blade, then the ear, then the full corn in the ear. The glory of Greece and of Rome is in the culmination of their civilization, art, literature and political power; and therein is their contribution to the higher civilizations which have succeeded.

So it must needs be with the great powers of to-day, Great Britain and Germany and America. . . .

Why doubt and repine, when the time of doubting and repining is inexorably past, and when doubting and repining can now do no good? Why shall not the United States, now that these lands and tribes have been intrusted to its disposition, enter upon the trust thus imposed upon it, with the determination that, as it began by freeing them from the yoke of oppression, it will go on and insure them still larger blessings of liberty and civilization, and will so bear itself toward them that in securing their welfare it shall also promote its own, and, as always happens when men or nations co-operate in the spirit of justice and good will, the reward shall come to both in their mutual increase?...

Meantime, our duty is to meet the responsibility that is upon us. Undoubtedly it would be easier if we could shift it from our shoulders and lay it down. It is with a wrench that any man, especially any son of New England familiar with its traditions and recalling its charms of provincial life, becomes aware 
that these must, betimes, give way to larger demands and more trying exigencies.

And yet, the fields that are before us are not altogether untrodden. It is not a new thing in the history of the world for an enlightened and civilized nation to deal with the less fortunate islands of remote seas.

A Christian nation should not lose heart at the opportunity of carrying its education, its industries, its institutions and its untold blessings to other and less fortunate people. For one, I trust with all my heart that the result of our new relations with the Philippines may be to aid them to the acquirement of the comforts, happiness and benefactions of our civilization; to educate them to their political elevation and to help them to the establishment of their own self-government and their own free existence.

Jonn D. Long, Address before the Home Market Club, in Boston Herald, February 17, 1899.

\section{R. OLNEY (1900)}

Hereafter as heretofore, our general policy must be and will be non-interference in the internal affairs of European states-hereafter as heretofore we shall claim paramountcy in things purely American - and hereafter as heretofore we shall autagonize any attempt by an European Power to forcibly plant its flag on the American continents. It cannot be doubted, however, that our new departure not merely unties our hands but fairly binds us to use them in a manner we have thus far not been accustomed to. We cannot assert ourselves as a Power whose interests and sympathies are as wide as civilization without assuming obligations corresponding to the claim - obligations to be all the more scrupulously recognized and performed that they lack the sanction of physical force. The first duty of every nation, as already observed, is to itself - is the promotion and conservation of its own interests. Its position as an active member of the international family does not require it ever to lose sight of that principle. But, just weight being given to that principle, and its abilities and resources and opportunities permitting, there is no reason why the United States should not act for the relief of suffering humanity and for the 
advancement of civilization wherever and whenever such action would be timely and effective. Should there, for example, be a recurrence of the Turkish massacres of Armenian Christians, not to stop them alone or in concert with others, could we do so without imperilling our own substantial interests, would be unworthy of us and inconsistent with our claims and aspirations as a great Power. We certainly could no longer shelter ourselves behind the time-honored excuse that we are an American Power exclusively, without concern with the affairs of the world at large.

Richard Otney, Growth of our Foreign Policy, in The Atlantic Monthly, LXXXV. 289-301 (March, 1900).

\section{CRITICAL COMMENT}

CHARLES FRANCIS ADAMS (1898)

Next as regards our fundamental principles of equality of human rights, and the consent of the governed as the only just basis of all government. The presence of the inferior races on our own soil, and our new problems connected with them in our dependencies, have led to much questioning of the correctness of those principles, which, for its outspoken frankness, at least, is greatly to be commended. It is argued that these, as principles, in the light of modern knowledge and conditions, are of doubtful general truth and limited application. True, when confined and carefully applied to citizens of the same blood and nationality; questionable, when applied to human beings of different race in one nationality; manifestly false, in the case of races less developed, and in other, especially tropical, countries. As fundamental principles, it is admitted, they were excellent for a young people struggling into recognition and limiting its attention narrowly to what only concerned itself; but have we not manifestly outgrown them, now that we ourselves have developed into a great World Power? For such there was and necessarily always will be, as between the superior and the inferior races, a manifest common sense foundation in caste, and in the rule of might when it presents itself in the form of what we are pleased to call Manifest Destiny. As to government being conditioned on the consent of the governed, 
it is obviously the bounden duty of the superior race to hold the inferior race in peaceful tutelage, and protect it against itself; and, furthermore, when it comes to deciding the momentous question of what races are superior and what inferior, what dominant and what subject, that is of necessity a question to be settled between the superior race and its own conscience; and one in regard to the correct settlement of which it indicates a tendency at once unpatriotic and "pessimistic," to assume that America could by any chance decide otherwise than correctly. Upon that score we must put implicit confidence in the sound instincts and Christian spirit of the dominant, that is, the stronger race.

It is the same with that other fundamental principle with which the name of Lexington is, from the historical point of view, so closely associated, - I refer, of course, to the revolutionary contention that representation is a necessary adjunct to taxation. This principle also, it is frankly argued, we have outgrown, in presence of our new responsibilities; and, as between the superior and inferior races, it is subject to obvious limitations. Here again, as between the policy of the "Open Door" and the Closed-Colonial-Market policy, the superior race is amenable to its own conscience only. It will doubtless on all suitable and convenient occasions bear in mind that it is a "Trustee for Civilization."

Cinarles Francis Adams, Imperiallsm and the Tracks of Our Forefathers. (Address delivered at Lexington, December 30, 1898.) 18.

RANDOLPH (1898)

The peace of Cuba will be our first concern, but we must not set up an unattainable standard of order for the Cubans, and then annex their island on the plea that they cannot govern it. Cuba may wait long for the order which we prescribe for ourselves, and indeed the peace of a Spanish-American state of the best type is not the peace of the United States.

The early installation of a Cuban goverument is desirable not only for the sake of the Cubans but because pending this event the United States must undertake the provisional control of the island. The undertaking will be sufficiently vexatious, even assuming, as I do, that it will be confided to trained soldiers 
and not to uniformed politicians. Yet it will be better to proloug our control than to recognize prematurely a Cuban government. When the authority of Spain shall disappear, the authority of the United States must replace it and prevail until a responsible local government shall be ready to assume control. 'The government of Cuba, which shall be definitely recognized by the United States, and may thereafter claim recognition from other nations, must be organized or ratified by the people of Cuba freely reliberating and acting under the protection of our impartial authority. Although the United States will not assume to present Cuba with a plan of government, they should condition recognition upon the adoption of a plan which shall establish a new nation upon principles of justice.

\section{Carman F. Randolph, Notes on the Foreign Policy of the United States. 6-7.}

W. G. SUMNER (1899)

War, expansion, and imperialism are questions of statesmanship and of nothing else. I disregard all other aspects of them, and all extraneous elements which have been intermingled with them. I received the other day a circular of a new educational enterprise in which it was urged that, on account of our new possessions, we ought now to devote especial study to history, political economy, and what is called political science. I asked myself, why? What more reason is there for pursuing these studies now on behalf of our dependencies than there was before to pursue them on behalf of ourselves? In our proceedings of 1898 , we made no use of whatever knowledge we had of any of these lines of study. The original and prime cause of the war was that it was a move of partisan tactics in the strife of parties at Washington. As soon as it seemed resolved npon, a number of interests began to see their advantage in it, and hastened to further it. It was necessary to make appeals to the public which would bring quite other motives to the support of the enterprise, and win the consent of classes who would never consent to either financial or political jobbery. Such appeals were found in sensational assertions which we had no means to verify, in phrases of alleged patriotism, in statements about Cuba and the Cubans which we now know to have been entirely untrue. 
Where was the statesmanship of all this? If it is not an established rule of statecraft that a statesman should never impose any sacrifices on his people for anything but their own interests, then it is useless to study political philosophy any more, for this is the alphabet of it. It is contrary to honest statesmanship to imperil the political welfare of the state for party interests. It was unstatesmanlike to publish a solemn declaration that we would not seize any territory, and especially to characterize such action in advance as "criminal aggression," for it was morally certain that we should come out of any war with Spain with conquered territory on our hands, and the people who wanted the war, or who consented to it, hoped that we would do so.

We talk about "liberty" all the time in a glib and easy way, as if liberty was a thing that men could have if they want it, and to any extent to which they want it. It is certain that a very large part of human liberty consists simply in the choice either to do a thing or to let it alone. If we decide to do it, a whole series of consequences is entailed upon us in regard to which it is exceedingly difficult, or impossible, for us to exercise any liberty at all. The proof of this from the case before us is so clear and easy that I need spend no words upon it. Here, then, you have the reason why it is a rule of sound statesmanship not to embark on an adventurous policy. A statesman could not be expected to know in advance that we should come out of the war with the Philippines on our hands, but it belongs to his education to warn him that a policy of adventure and of gratuitous enterprise would be sure to entail embarrassments of some kind. What comes to us in the evolution of our own life and interests, that we must meet; what we go to seek which lies beyond that domain, is a waste of our energy and a compromise of our liberty and welfare. If this is not sound doctrine, then the historical and social sciences have nothing to teach us which is worth any trouble. . . .

We assume that what we like and practise, and what we think better, must come as a welcome blessing to SpanishAmericans and Filipinos. This is grossly and obviously untrue. They hate our ways. They are hostile to our ideas. Our religion, language, institutions, and manners offend them. 
They like their own ways, and if we appear, anongst them as rulers, there will be social discord on all the great departments of social interest. The most important thing which we shall inherit from the Spauiards will be the task of suppressing rebellions. If the United States takes out of the hands of Spain her mission, on the ground that Spain is not executing it well, and if this nation, in its turn, attempts to be school-mistress to others, it will shrivel up into the same vanity and self-conceit of which Spain now presents an example. To read our current literature one would think that we were already well on the way to it. Now, the great reason why all these enterprises, which begin by saying to somebody else: We know what is good for you, better than you know yourself, and we are going to make you do it - are false and wrong, is that they violate liberty; or, to turn the same statement into other words: the reason why liberty, of which we Americans talk so much, is a good thing, is, that it means leaving people to live out their own lives in their own way, while we do the same. If we believe in liberty, as an American principle, why do we not stand by it? Why are we going to throw it away to enter upon a Spanish poliey of dominion and regulation?

William G. Sumner, The Conquest of the United States by Spain.

\section{SCHURZ (1899)}

If ever, it behooves the American people to think and act with calm deliberation, for the character and future of the republic and the welfare of its people now living and yet to be born are in unprecedented jeopardy. To form a eandid juigment of what this republic has been, what it may become, and what it ought to be, let us first recall to our minds its condition before the recent Spanish War.

Our government was, in the words of Abraham Lincoln, "the government of the people, by the people, and for the people." It was the noblest ambition of all true Americans to carry this democratic government to the highest degree of perfection in justice, in probity, in assured peace, in the security of human rights, in progressive civilization; to solve the problem of pop- 
ular self-government on the grandest scale, and thus to make this republic the example and guiding star of mankind.

We had invited the oppressed of all nations to find shelter here, and to enjoy with us the blessings of free institutions. They came by the millions. Some were not so welcome as others, but under the assimilating force of American life in our temperate climate, which stimulates the working energies, nurses the spirit of orderly freedom, and thus favors the growth of democracies, they become good Americans, most in the first, all in the following generations. And so with all the bloodcrossings caused by the motley immigration, we became a substantially homogeneous people, united by common political beliefs and ideals, by coinmon interests, laws, and aspirations, - in one word, a nation. . . .

Then came the Spanish War. A few vigorous blows laid the fecble enemy helpless at our feet. The whole scene seemed to have suddenly changed. According to the solemn proclamation of our government, the war had been undertaken solely for the liberation of Cuba, as a war of humanity and not of conquest. But our easy victories had put conquest within our reach, and when our arms occupied foreign territory, a loud demand arose that, pledge or no pledge to the contrary, the conquests should be kept, even the Philippines on the other side of the globe, and that as to Cuba herself, independence would only be a provisional formality. Why not? was the cry. Has not the career of the republic almost from its very beginning been one of territorial expansion? Has it not acquired Louisiana, Florida, Texas, the vast countries that came to us through the Mexican War, and Alaska, and has it not digested them well? Were not those acquisitions much larger than those now in contemplation? If the republic could digest the old, why not the new? What is the difference?...

- . This difference called forth that great pæan of human liberty, the American Declaration of Independence, - a document which, I regret to say, seems, owing to the intoxication of conquest, to have lost much of its charm among some of our fellow eitizens. Its fundamental principle was that "governments derive their just powers from the consent of the goverued." We are now told that we have never fully lived up to 
that principle, and that, therefore, in our new policy we may cast it aside altogether. But I say to you that, if we are true believers in democratic government, it is our duty to move in the direction toward the full realization of that principle, and not in the direction away from it. If you tell me that we cannot govern the people of those new possessions in accordance with that principle, then I answer that this is a good reasou why this democracy should not attempt to govern them at all.

If we do, we shall transform the government of the people, for the people, and by the people, for which Abraham Lincoln lived, into a government of one part of the people, the strong, over another part, the weak. Such an abandonment of a fundamental principle as a permanent policy may at first seem to bear only upon more or less distant dependencies, but it can hardly fail in its ultimate effects to disturb the rule of the same principle in the conduct of democratic government at home. And I warn the American people that a democracy cannot so deny its faith as to the vital conditions of its being, it cannot long play the king over subject populations, without ereating within itself ways of thinking and habits of action most dangerous to its own vitality; - most dangerous especially to those classes of society which are the least powerful in the assertion, and the most helpless in the defence of their rights. Let the poor and the men who earn their bread by the labor of their hands pause and consider well before they give their assent to a policy so deliberately forgetful of the equality of rights.

Carl Schurz, American Imperialism. (Address before the University of Chicago, January 4, 1899.) 9-11.

HOAR (1899)

The question is this: Have we the right, as doubtless we have the physical power, to enter upon the government of ten or twelre million subject people without constitutional restraint? Of that question the Senator from Connecticut takes the affirmative. And upon that question I desire to join issue.

Mr. President, I am no strict constructionist. I am no alarmist. I believe this country to be a nation, a sovereign nation. I believe Congress to possess all the powers which are 
necessary to accomplish under the most generous anci liberal construction the great objects which the men who framed the Constitution and the people who adopted it desired to accomplish by its instrumentality. I was bred, I might almost say I was born, in the faith, which $I$ inherited from the men whose blood is in my veins, of the party of Hamilton and Washington and Webster and Sumner, and not in that of Madison or Calhoun or the strict constructionists. The men by whose hands Connecticut signed the Declaration of Independence, who in her behalf helped frame the Constitution, who represented her in either House of Congress in the great Administrations of Washington and John Adams, were of that way of thinking. But the man of them most thoroughgoing and extreme, Hamilton himself, Ellsworth himself, Adams himself, would have looked with amazement if not with horror upon the doctrines asserted by the honorable Senator from Connecticut to-day. I am not speaking only of his denial of the great doetrine of constitutional liberty and of political morality that government derives its just power from the consent of the governed, and that any people has the right, when it thinks its existing government is destructive of the great ends of life, liberty, and happiness, to throw off the old government and make a new one for itself, and certainly if it have that right no other man has the right to impose one on it against its consent. But I am not speaking of that. I am speaking of his astonishing and most extravagant construction of the powers of Congress under the Constitution. ...

Now, let us trace for a moment the history of this beantiful, angust, pure, invincible sovereign of ours. The idea that our fathers intended to clothe it with such a sovereignty is as repngnant to me as the idea that because God created a seraph, or an archangel, or even a man in his own image, he intended that he should be at liberty commit murder or robbery or any form of bestiality because he had clothed him with the physical power to accomplish it.

Expositio contemporunea maxime valet. The great contemporaneous exposition of the Constitution is to be found in the Declaration of Independence. Over every clause, syllable, and letter of the Constitution the Declaration of Independence 
pours its blazing torchlight. The same men framed it. The same States confirmed it. The same people pledged their lives, their fortunes, and their sacred honor to support it. The great characters in the constitutional convention were the great characters of the Continental Congress. There are undoubtedly, among its burning and shining truths, one or two which the convention that adopted it were not prepared themselves at once to put into practice. But they placed them before their countrymen as an ideal moral law to which the liberty of the people was to aspire and to ascend as soon as the nature of existing conditions would admit. Doubtless slavery was inconsistent with it, as Jefferson, its great author, has in more than one place left on record. But at last in the strife of a great civil war the truth of the Declaration prevailed and the falsehood of slavery went down, and at last the Constitution of the United States conformed to the Declaration and it has become the law of the land, and its great doctrines of liberty are written upon the American flag wherever the American flag floats. Who shall haul them down?...

When the delegates of the Old Thirteen set their hands to that Declaration, the people of the United States stepped forth armed in its invincible panoply, like Minerva from the head of Jove, the greatest world power the world had ever seen. The seed they planted on that July morning grew up into crowns and sceptres. Whenever we depart from it the world power of the Great Republic is at an end. . . .

At the close of the nineteenth century the American Republic, after its example in abolishing slavery has spread through the world, is asked by the Senator from Connecticut to adopt $a^{\text {- }}$ doctrine of constitutional expansion on the principle that it is right to conquer, buy, and subject a whole nation if we happen to deem it for their good, - for their good as we conceive it, and not as they conceive it.

Mr. President, Abraham Lincoln said, "No man was ever created good enough to own another." No nation was ever created good enough to own another.

No single American workman, no humble American home, will ever be better or happier for the constitutional doctrine 
which the Senator from Connecticut proclaims. If it be adopted here not only the workman's wages will be diminished, not only will the burden of taxation be increased, not only, like the peasant of Europe, will he be born with a heavy debt about his neck and will stagger with an armed soldier upon his back, but his dignity will be dishonored and his manhood discrowned by the act of his own Government.

George F. Hoar, No Constitutional Power to conquer Foreign Nations and hold their People in Subjection against their Will. (Speech in the Senate, January 9, 1899.) 11-40.

\section{BURGESS (1899)}

I cannot but regard as sophistical the argument for taking the Philippine Islands that is drawn from the fact of our having taken Louisiana, Florida, Texas, California, New Mexico, Oregou and even Alaska. All of these districts, except perhaps Alaska, are geographically natural parts of the United States. They were necessary to the national development of the United States. Their continued possession by other powers would have been a direct danger to the interests, if not to existence, of the United States. This latter proposition applies also, in some degree, to Alaska. The argument drawn from our past expansion would be more sound if it were used in reference to Cuba. Cuba commands the entrances to the Gulf of Mexico and the approaches from the sea to the southern boundary of the United States. The possession of this island by the United States may become - is even likely to become - a national necessity. But the Philippine Islands stand in no such relation to us. The principle of expansion which we have heretofore followed is national expansion. The expansion involved in the occupation of the Philippines is world-empire expansion. These are not the same thing; and while snccessful world-empire expansion may require a preceding national expansion, a snecessful national expansion does not require world-empire expansion. In a word, the steps in national expansion are not precedents for world-empire expansion.

Jonn W. Burgess, How may the United States govern its Extra-Continental Territory? in Political Science Quarterly, XIV. 2-3 (March, 1899), 


\section{FART (1900)}

At the end of the Revolution the United States had a most excellent opportunity to remain within the former limits of the thirteen colonies, for in the peace negotiations of 1782 and 1783 it was the distinct purpose of France and Spain, and at times of England, to make the water-shed of the Appalachian chain practically the western boundary. . . .

Three different areas, adjacent to the original Euglish colonies, were to be disposed of in the negotiations. First, some of the Americans doubted whether "we could ever have a real peace, with Canada or Nova Scotia in the hands of the Euglish." The second region was the northwest territory, in which the Americans had the right of occupation by conquest in a considerable part of the posts. The third area was the territory south of the Ohio River, most of which had not been under the jurisdiction of any English colony prior to the Revolution.

The three arch-expansionists of that period, Franklin, Jay, and Adams, without much difficulty secured English consent to making the Mississippi the western boundary, as required by the instruction of Congress of 1779 . . .

Having thus inangurated the policy of territorial expansion, our forefathers next set themselves to the great task of furnishing a colonial government, and during the ten years from 1780 to 1790 this was one of the chief concerns of Congress. ...

The framers of the Constitution perfectly understood that the power which they gave Congress to make war included the power to conquer territory, and that the power to make treaties included the authority to annex by peaceful concession. . . .

During the first decade under the Federal Constitution the nation did not yet know its own strength, or venture to predict its own future. . .

The geographical and political conditions of the time speedily revived the spirit of political extension. Americans could put up with the exclusion from the lower Mississippi and the Gulf so long as that territory was in the hands of weak and declining Spain. European wars and treaties now began, however, 
to have far-reaching effects, extending to the New World, for in $\mathbf{1 7 9 5}$ and 1796 the French government began to urge upon Spain the transfer of the former French province of Louisiana. ...

People speak of the "Louisiana negotiations" as though there had been two sides and a balancing of propositions. In reality the province was thrown to the United States, as the Caliph Harun-al-Raschid might have given a palace to a poor merchant who had admired the portico. . . .

So evident were the practical advantages of annexing Louisiana that much of the anti-annexation argument was directed against the future creation of a new State, from which would come senators and representatives. . .

The favorite objection was the distance of the new territory....

Another objection was the cost of the territory. . . .

To sum up the objections to the treaty: France had no right to eede it; the United States had no right to receive it, under the conditions of the treaty; it was not worth having on any terms; it was vast; it would disturb the balance of the Union; it would draw valued inhabitants from other parts of the United States; it would poison the settlers ; the treaty was an extra-constitutional proceeding; the President and Senate did not represent the opinion of the country; and patriotic men ought to oppose " such a pernicious measure as the admission of Louisiana, of a world, and such a world, into our Union." ...

While members of Congress, as well as people outside, were discussing the question of Louisiana, Jefferson had already dispatched Lewis and Clarke to explore the upper Missouri and find a practicable road across to the Pacific; but though bold to enlarge his country, he still had constitutional qualms, which were not removed by the Senate vote of 24 to 7 ratifying the treaty, nor by the House vote of 90 to 25 granting the necessary appropriation. Jefferson drew up a constitutional amendment intended to be an indemnity for him, and to define the principles of annexation for later times; but his own friends laughed at the irlea, and from that day to this the territory has remained a part of the United States, with no further constitutional controversies. 
If this study were carried farther forward, the same evident, hearty, and unappeasable Anglo-Saxon land-hunger would be found appearing in the War of 1812, in the boundary controversies with Great Britain, in the annexations of Texas and California. Whether that was a right and wholesome hunger must be determined from the last fifty years of national history. But wise or unwise, far-seeing or haphazard, consecutive or accidental, good or evil, the policy of our forefathers was a policy of territorial extension, and they met and supposed they had surmounted most of the problems which have now returned to vex American public men, and to give concern to those who love their country.

Albert Bushnell Hart, Territorial Problems, in Harper's Monthly, Vol. I. pp. 312-320 passim (January, 1900).

\section{ABBOTT (1900)}

We have believed and we still believe that the war against Spain was a most just and necessary war; that on it we had a right to inroke " the considerate judgment of mankind and the gracious favor of Almighty God," and that by both it has been sanctioned; that if by his providence God has ever signified his approval of war, he did so by the unparalleled successes of our navy at Manila and Santiago; that if ever war received popular approval from the common people hostile to hierarchical and oligarchic oppression, our war against Spain has had such approval from the common people of other lands. And while the issue in the Philippines is not equally clear, because it is possible that statesmanship could have avoided war with the Filipinos, yet we have believed and still believe that it was our duty to save, by diplomacy if possible, by war if necessary, those islands from the anarchy in which the pseudo-government of the Aguinaldo oligarchy would inevitably have involved them.

The war with a self-seeking oligarchy in Spain and the war with a self-seeking oligarchy in the Philippines is over, and now there commences a war with the same spirit of self-seeking at home. We are glad that the American flag floats over Puerto Rico and over the Philippines; and we believe that the Amer- 
ican flag will carry to those lands which it covers the same blessings which it has carried in successive eras of expansion to new American territory on this continent. But it is clear that this result and their prosperity and our National honor are threatened by short-sighted politicians and greedy traders, and that those who are expansionists but not imperialists must join hands in a vigorous and determined appeal to the American people to secure the welfare of our dependencies and preserve the honor of our Nation. And it seems to us that those who have not been expansionists might well join those who are expansionists but are not imperialists upon this new issue now presented.

In determining our duty toward our dependencies the Nation is bound neither by the specific provisions of its written Constitution defining the rights of States and Territories, nor by the specific counsels and the unwritten traditions of the past. It is not bound by the first, because Puerto Rico and the Philippines are neither States nor Territories, and have not the specific rights which the written Constitution gives to States and Territories. It is not bound by the second, because counsels given and traditions created in one epoch and applicable to one state of circumstances are not bonds to bind the Nation in another epoch and under different circumstances. . . .

But we are bound by those general principles of justice and humanity which are equally applicable to all epochs and in all circumstances, and we must preserve in our new conditions that spirit which constitutes what we may call the personality of the Nation, the loss of which would involve the real death of the Nation. The eternal principle of justice which must control us is that governments exist for the benefit of the governed; the American spirit which must control us is that the ideal form of government is self-government. . . The selfgovernment of a community rests on the capacity of the individuals in the community to govern themselves; if there is no such capacity in the individuals, there will be no such capacity in the community. 'That capacity may be developed by long centuries of training, as in the Anglo-Saxon race; it may be developed by contiguity and companionship with men who already possess such capacity, as in the case of our own immi- 
grant populations. But to assume that it is possessed by a people without training, and to leave them to exercise it without supervision, counsel, or control, would be a blunder only comparable to that of a father who should affirm that all children have a dormant capacity for self-support, and therefore the new-horn babe may be left to take care of himself. Moses required a princess mother, and even Romulus and Remus would have starved but for the tender mercies of a she-wolf.

But, although self-government cannot be assumed as the starting-point for Puerto Rico or the Philippines, it must be kept constantly in view as the goal. American institutions are built on self-government. In this respect America is more democratic than England. In England the political powers of the county and the town are derived from the central Parliament; in America the powers of Congress are derived from the States. The source of authority in the one nation is a central fountain, in the other it is many local springs. Our object in Puerto Rico and the Philippines must be to develop a local self-government in town and county, and from this build up a self-government for the entire community, and ont of this selfgovernment must grow the final relations between that selfgoverning community and the Nation. The ultimate relation must be either that of a State to the Nation, or that of an independent self-governing colony to a mother-land; it must not be that of a Roman province to a central imperial authority. The latter would be imperialism, and it would not be expansion.

Meanwhile, and as a first step in this process, we must govern our dependencies with unselfish justice and equity. For there is only one way of passing from anarchy to self-government - namely, through government from without.

Lyman Aввотт, Expansion, but not Imperialism, in The Outlook, LXIV. 662-663 (March 24, 1900).

LODGE (1900)

The capacity of a people, moreover, for free and representative government is not in the least a matter of guesswork. The forms of government to which nations or races naturally tend may easily be discovered from history. You can follow the 
story of political freedom and representative government among the English-speaking people back across the centuries until you reach the Teutonic tribes emerging from the forests of Germany and bringing with them forms of local self-government which are repeated to-day in the pure democracies of the New England town meeting. The tendencies and instincts of the Teutonic race which, reaching from the Arctic Circle to the Alps, swept down upon the Roman Empire, were clear at the outset. Yet the indivirlual freedom and the highly developed forms of free government in which these tendencies and instincts have culminated in certain countries and under the most favorable conditions have been the slow growth of nearly fifteen hundred year's.

There never has been, on the other hand, the slightest indication of any desire for what we call freedom or representative government east of Constantinople. The battle of Marathon was but the struggle between a race which had the instinct and desire for freedom and the opposite principle. The form of government natural to the Asiatic has always been a despotism. You may search the history of Asia and of the East for the slightest trace, not merely of any understanding, but of any desire for political liberty, as we understand the word. In the village communities of India, in the Mura of Japan, in the towns and villages of China you can find forms of local selfgovernment which are as successful as they are ancient. The Malays of Java and of the Philippines as well display the same capacity, and on this old and deep-rooted practice the selfgovernment of provinces and states can, under proper auspices, be built up. It is just here that our work ought to begin. But this local self-government never went beyond the town or the village; it never grew and spread, as was the case with the Teutonic tribes and their descendants. The only central, state or national governments which the Eastern and Asiatic people have formed or set up have been invariably despotisms. . . .

You cannot change race tendencies in a moment. Habits of thought slowly formed through long periods of time and based on physical, climatic, and geographical peculiarities are more indestructible than the pyramids themselves. Only by very slow processes can they be morlified or changed... 
The problem we have before us is to give to people who have no conception of free government, as we understand it and carry it on, the opportunity to learn that lesson. What better proof could there be of their present unfitness for selfgovernment than their senseless attacks upon us before anything had been done? Could anything demonstrate more fully the need of time and opportunity to learn the principles of selfgovernment than this assault upon liberators and friends at the bidding of a self-seeking, self-appointed, unscrupulous autocrat and dictator? Some of the inhabitants of the Philippines, who have had the benefit of Christianity and of a measure of education, will, I have no doubt, under our fostering care and with peace and order, assume at once a degree of self-government and advance constantly, with our aid, toward a still larger exercise of that inestimable privilege, but to abandon those islands is to leave them to anarchy, to short-lived military dictatorships, to the struggle of factions, and, in a very brief time, to their seizure by some great Western power who will not be at all desirous to train them in the principles of freedom, as we are, but who will take them because the world is no longer large enough to permit some of its most valuable portions to lie barren and ruined, the miserable results of foolish political experiments. ...

From the dispatch of May 26 onward the attitude of our Government was clear and unmistakable. But every real hope, every proper promise, was freely offered and never violated. There are many duties imposed upon a President in which it is easy to imagine a personal or selfish motive, in which such motives might exist even if they do not. But here even the most malignant must be at a loss to find the existence of a bad motive possible.

Suddenly at the end of the Spanish war we were confronted with the question of what should be done with the Philippines. Their fate was in our hands. We were all able to discuss them and to speculate as to what that fate should be. No responsibility rested upon us. But one man had to act. While the rest of the world was talking he had to be doing. The iron hand of necessity was upon his shoulder, and upon his alone. Act he must. No man in that high office seeks new burdens 
and fresh responsibilities or longs to enter on new policies with the unforeseen dangers which lie thick along untried paths. Every selfish motive, every personal interest, cried out against it. Every selfish motive, every personal interest, urged the President to let the Philippines go, and, like Gallio, to care for none of these things. It was so easy to pass by on the other side. But he faced the new conditions which surged up around him. When others then knew little he knew much. Thus he came to see what duty demanded, duty to ourselves and to others. Thus he came to see what the interests of the American people required. Guided by this sense of duty, by the spirit of the American people in the past, by a wise statesmanship, which looked deeply into the future, he boldly took the islands. Since this great decision his policy has been firm and consistent. He has sought only what was best for the people of those islands and for his own people.

The policy we offer, on the other hand, is simple and straightforward. We believe in the frank acceptance of existing facts, and in dealing with them as they are and not on a theory of what they might or ought to be. We accept the fact that the Philippine Islands are ours to-day and that we are responsible for them before the world. The next fact is that there is a war in those islands, which, with its chief in hiding, and no semblance of a government, has now degenerated into mere guerilla fighting and brigandage, with a precarious existence predicated on the November elections. Our immediate duty, therefore, is to suppress this disorder, put an end to fighting, and restore peace and order. That is what we are doing. That is all we are called upon to do in order to meet the demands of the living present. Beyond this we ought not to go by a legislative act, except to make such provision that there may be no delay iu re-establishing civil government when the war ends. The question of our constitutional right and power to govern those islands in any way we please I shall not discuss. Not only is it still in the future, but if authority is lacking, the Constitution can be amended. Personally, I have no doubt that our Constitution gives full right and authority to hold and govern the Philippines without making them either economically or politically part of our system, neither of which they should ever be. 
When our great Chief Justice, John Marshall - "clarum et venerabile nomen" - declared in the Cherokee case that the United States could have under its control, exereised by treaty or the laws of Congress, a "domestic and dependent nation," I think he solved the question of our constitutional relations to the Philippines. Further than the acts and the policy which I have just stated, I can only give my own opinion and belief as to the future, and as to the course to be pursued in the Philippines. I hope and believe that we shall retain the islands, and that, peace and order once restored, we shall and should re-establish civil government, beginning with the towns and villages, where the inhabitants are able to manage their own affairs. We should give them honest admiuistration, and prompt and efficient courts. We should see to it that there is entire protection to persons and property, in order to encourage the development of the islands by the assurance of safety to investors of capital. All men should be protected in the free exercise of their religion, and the doors thrown open to missionaries of all Christian sects. The land, which belongs to the people, and of which they have been robbed in the past, should be returned to them and their titles made secure. We should inaugurate and carry forward, in the most earnest and liberal way, a comprehensive system of popular education. Finally, while we bring prosperity to the islands by developing their resources, we should, as rapidly as conditions will permit, bestow upon them self-goverument and home rule. Such, in outline, is the policy which I believe can be and will be pursued towards the Philippines. It will require time, patience, honesty, and ability for its completion, but it is thoroughly practicable and reasonable. ...

I do not think the Filipinos are fit for self-government as we understand it, and I am certain that if we left them alone the result would be disastrous to them and discreditable to us. Left to themselves the islands, if history, facts, and experience teach anything, would sink into a great group of Haitis and St. Domingos, with this important clifference, that there would be no Monroe doctrine to prevent other nations from interfering to put an end to the ruin of the people and the conversion of a fair land into a useless and improductive waste. The nations of 
Europe are not going to stand idly by and see the islands of the Philippines given over to anarchy and dictatorships of the Haitian type, while their waters swarm again with pirates whom Spain suppressed, and whom we have now the responsibility of keeping down and extinguishing. We have no right to give those islands over to anarehy, tyrannies, and piracy, and I hope we have too much self-respect to hand them over to European powers with the confession that they can restore peace and order more kindly and justly than we, and lead the inhabitants onward to a larger liberty and a more complete self-government than we ean bestow upon them. Therefore, Mr. President, I desire to show why I feel so confident that the Filipinos are not now fit for self-government, and that their only hope of reaching the freedom, self-government, and eivilization which we desire them to bave lies in our now holding, governing, and controlling the islands.

Henry Cabot Lodge, The Retention of the Philippine Islands. (Speech in the Senate, March 7, 1900.) 14-35 passim.

\section{GIDDINGS (1900)}

Never since the Constitution was ratified by the thirteen original commonwealths have the American people, as a whole, felt so confident of their place among the nations, or so sure of the excellence of their polity, and of the vitality of their laws and immunities. Never have they been so profoundly convinced that their greatest work for civilization lies not in the past, but in the future. They stand at the beginning of the twentieth century, in their own minds fully assured that the responsibilities which they are about to face, and that the achierements which they expect to complete, are immeasurably greater than are those which have crowned the century of their experiment and discipline.

From the Louisiana purchase to the annexation of Hawaii we have seized, with unhesitating promptness, every opportunity to broaden our national domain, and to extend our institutions to annexed populations. Even more convineingly has our vigour been shown in the fearlessness with which the eost of every new responsibility has been met. Whether this cost has been 
paid in treasure or in blood, the American people has met it without one moment's hesitation. ...

. Next to vitality, and supplementing it, the basis of faith in the future is a sound, full knowledge of the present and the past. The American people know facts about their own numbers, resources, and activities, which fully justify their belief that they are at the beginning, not approaching the end, of their evolution as a civilized nation. Only in a few spots within our national domain does the density of population yet approach the average density of the older European countries. . . .

Into this domain the population of Europe continues to discharge its overflow; and the stream of immigration shows no marked decrease save in the exceptional years of industrial depression. Of chief significance, however, is the fact that the greater part of all the immigration that we have thus far received has consisted of the same nationalities from whose amalgamation the original American stock was produced. . . .

When we remember that it was the crossing of the Germanic and the Celtic stocks that produced the English race itself, we are obliged to assume that the future American people will be substantially the same human stuff that created the English common law, founded the Parliamentary institutions, established American self-government, and framed the Constitution of the United States.

Franklis H. Giddings, Democracy and Empire. 295-297. 


\section{APPENDIX A}

\section{ESSENTIALS IN ENGLISH CONSTITUTIONAL HISTORY}

This analysis of English history has been tested by actual class use, and is adapted for the documents which form the body of the work. The titles of the documents are distinguished in the Essentials by appearing in italics.

§ 1. Essentials in Early Teutonic Life. -2000 B. c. -449 A. D.

1. Geographical enviroument. Effect: Racial characteristics.

2. Nomadic tribes of Aryan family.

Effect: Tribal settlements formed gradually.

3. Leadership of divisions.

Effect: Beginning of local government.

4. Spirit engendered by "tunmote."

Effect: Germ of free citizenship.

5. Development of the Witenagemot.

Effect: Government by the "freemen."

6. Migration into Britain.

Effect: Subjection of the Celts.

$\S 2$. Essentials in the AngloSaxon Period. - 449-1066.

I. Conditions of Making a KingDosr.

1. To gain territory.

Effect: The Heptarchy.

2. To establish over-lordship.

Effect: Egbert, "King of the English."
3. To keep out the Danes.

Effect: Peace of IVedmore (9th c.).

II. Keeping A Kixgdom.

1. To hold territory against Danes.

Effect : Government under Dunstan's influence.

2. Weakness of Ethelred II.'s policy.

Effect: Danish invasion.

3. Edmund Ironsides versus $\mathrm{Ca}$ nute.

Effect : Canute's reign of power.

4. Anarchy in Danish government.

Effect : Restoration of Saxou line.

5. Foreign influence versus Godwin's party.

Effect: Exile of the latter.

6. Saxons versus Normans.

Effect : Norman Conquest.

§ 3. Essentials in the NormanAngevin Period. - 10661400.

I. The Development of a SysTEM of GovernMent.

1. Struggle for territory and possession.

Effect : Complete conquest of England by William I. 
2. Establishment of the feudal system.

Effect : Supremacy of the King of England.

3. Censns and oath of allegiance.

Effect: Suppression of Larons.

II. Extension of Government to the People.

1. Henry I.'s Charter of Liberties. 1101.

Effect: Privileges to the people. (Curia Regis.)

2. Henry II.'s Laws.

liffect: Purer courts.

3. Magna Charta. 1215.

Effect: "Liberty of the subject."

4. Summons of Representatives to Parliament. 1295.

Effect: Broadening government.

5. Edward I.'s Confirmation of Magna Charta. 1297.

Effect: "No taxation without representation."

6. Overthrow of system of landtenure.

Effect: Peasant revolt.

7. Deposition of king.

Yffect: Parliamentary rights.

$\S 4$. Essentials in the Lancastrian-Yorkish Period. 1400-1485.

I. Assertion of Constitutional Power.

1. Usurpation of Henry IV. upheld by larliament.

Effect: Power of Parliament.

2. Henry V.'s policy.

Effect: Conciliation at home ; war abroad.

3. Parliamentary demands during reigns of Henry $V$. and Henry VI.

Effect: Power in House of Commons.

4. Trial by Jury strengthened. 1429.
Effect: Beginning of modern system.

II. Deca Dence of Constitutional Power.

1. King's minority demands protectorate.

Effect: Political factions.

2. Yorkish influence.

Effect: Compromise and treaty.

3. Civil war.

Effect: Constitutional power broken.

4. Edward IV. usurps throne.

Effect: Margaret's claim.

5. Edward's restoration.

Effect: Pressure of kingly power in taxation.

6. Richard III. usurps throne.

Effect: Overthrow of York party.

§ 5. Essentials in the Tudor Period. - 1485-1603.

I. The New Spirit in Investigation, Exploration, AND Thолght.

1. England's geographical interests.

Effect: Claims in America.

2. Henry VII.'s policy.

Effect : Continental alliances.

3. l'rogress of the " new learning."

Effect: Protestantism gets a foothold.

4. Henry VIII.'s “balance of power."

Effect: Peace permits development.

5. Wolsey's policy.

Effect: King's supremacy.

6. Cranmer's and Cromwell's policy.

Effect: Establishment of the Anglican Church.

II. Party Factions develop in THE Governaent.

1. Policy of Somerset and Northumberland. 
Effect: Overthrow of Roman Catholic power.

2. Policy of Mary Tudor.

Effect: Overthrow of Protestantism.

3. Reaction by Lords of the Council.

Effect: Elizabeth crowned.

III. Growth of National Pride and Power.

1. Elizabeth's policy with factions. Effect: Unity in State.

2. Encouragement of art and literature.

Effect: "Elizabethan Age."

3. Colonization in Ireland and America.

Effect: English Protestant settlements.

4. Spain's policy and Spanish Armada.

Effect: England's defiance.

\$6. Essentials in the Stuart Period. - 1603-1714.

Constitutional struggle between King and Commons.

I. Divine Right of Kings versus Parliament.

1. Attempt to establish control of religion.

Effect : Failure to wnite sects.

2. Demands of Parliament for redress of grievances before taxation.

Effect: Arbitrary rule of king.

3. Enthusiasm for colonization.

Effect : Early emigration into Virginia.

4. Charles I.'s establishment of "Divine Right of Kings."

Effect: Petition of Right, 1628.

5. Establishment of "System Thorough."

Fffect: Grand Remonstrance.

6. Attempted suppression of free speech in P'arliament.

Fffect: Civil war.
7. Military sway.

Effect: Execntion of king.

II. Establishment of the CoMMONWEALTH.

1. Cromwell versus Charles II.

Effect: Subjection of Scotland and Ireland.

2. Expulsion of Long Parliament. Effect : Protectorate.

3. Influence of attempted frames of government.

The Agreement of the People. 1648-49.

Instrument of Government. 1653.

Effect : Temporarily inadequate; later, types of constitutions.

4. Cromwell's policy.

Effect: Rule of strength and toleration.

5. Inadequacy of Protectorate under Richard Cromwell.

Effect: Overthrow of Com. monwealth.

III. Restoration OF Stuart HoUse. - 1660 .

1. Re-establishment of ancient civil polity.

Effect : Temporary union of English people.

2. Foreign policy.

Effect : Triple Alliance versus French subsidy.

3. Declaration of Indnlgence.

Effect: Oatlı of Supremacy; Test Act.

4. Legislation for the "subject."

Effect: Habcas Corpus Act, 1679.

5. Agitation of Exclusion Bill.

Effect : Monmouth party.

6. James II.'s policy.

Effect: Monmouth rebellion.

7. "Dispensing power."

Effect: Growing tyranny.

8. Importance of "Succession."

Effect: William of Orange invited to England. 
9. Abdication of James II.

Effect : Interregnum; "Declaration of Rights."

IV. The Revolution of 1688.

1. Policy of William and Mary. Effect: Bill of Rights, 1689.

2. Insurrections.

Effect : Scotland and Ireland subdued.

3. Alliance with Holland against Lonis XIV.

Effect: William of Orange recognized by Peace of Ryswick.

4. The cause of the Pretender influences England to join the Grand Alliance.

Effect: England's share in the War of the Spanish Succession.

5. Act of Settlement. 1701.

Effect: Protestant line secured.

6. Anne's ministry.

Effect: Power of Whig nobles.

7. Dissolution of the Grand Alliance.

Effect: Treaty of Utrecht affects England in the Old World and the New World.

8. Fall of Marlborough.

Effect: 'Tory power arises for time being.

\$7. Essentials in the Hanoverian Period. - 1714-1815.

I. Whig Supremact.

1. Influence of Act of Settlement.

Effect: George I.crowned king.

2. Policy of the Walpole ministry.

Effect: Reign of peace.

3. Development of economics.

Effect: Difficulties arising in the legislation of reforms.

4. Foreign policy.

Effect: England's share in the War of the Austrian Succession.
5. Claims of the Jacobites. Effect: The Culloden field.

6. Broadening of colonial system. Effect : Expansion of Englaud.

7. Pitt's early policy. Effect: Foreign relations.

8. Eugland's share in Seven Years' War.

Effect: French-American possessions become English.

9. Eastern administration.

Effect : England's eastern empire.

II. Developjent of Colonial GovernMext.

1. English control.

Effect : Neglect gives the colonies confidence.

2. Colonial charters.

Effect: Conception of rights of Englishmen; Dummer's Defence of the Charters.

III. English Side of the American Revolution.

1. Colonial regulations.

Effect: Principles of the House of Commons versus royal power.

2. Policy of Lord North.

Effect : Colonial defiance.

3. Struggle for independence by American colonies.

Effect: Treaty of Paris, 1783.

IV. NAPOLEONIC WARS.

1. Continental relations.

Effect: Alliance against $\mathrm{Na}$ poleon.

2. Continental system versus Orders in Conncil.

Effect : Commercial life crippled.

3. War of 1812 .

Effect: United States recognized as a "world-power."

4. Wellington versus Napoleon.

Effect: Fall of Napoleon. 


\section{APPENDIX B}

\section{ESSENTIALS IN AMERICAN CONSTITUTIONAL HISTORY}

This analysis of American history is especially designed to be a background for the study of the documents printed above. The titles appear in italics.

\section{$\S 1$. Essentials in the Rivalry for Possession of the New World. - 1492-1689.}

1. Search for a westeru passage to Asia.

Effect : Discovery of America.

2. Claims of Spain.

Effect: Spanish settlements in the South.

3. Claims of England.

Effect: Virginia and the Atlantic seacoast.

4. Claims of France.

Effect: Settlements in the North; Louisiana.

5. Minor claims.

Effect: Dutch and Swedish settlements.

6. Growing power in New France and New England.

Effect: French and Indian Wars.

§ 2. Essentials in the Growth of Government in English Colonies. - 1607-1643.

I. James I.'s policy in granting royal charters.

Effect: London and Plymouth companies.

2. Influence of the principle of local self-goverument.

Effect: Iouse of Burgesses, 1619 , under Virginia charter; independence of gov- erument in Massachusetts Bay Company.

3. Influeuce of the spirit of organization.

Effect: "Freemen," towns, counties, assemblies.

4. Influence of the doctrine of vested rights protected by charters.

Effect : Renewal of charters.

5. Massachusetts's special prosperity.

Effect: Colonial jealousies.

6. Disorder in the government in England.

Effect : No interference in the colonies, hence rapid development.

7. Search for freedom from colonial control by Massachusetts.

Effect: Fresh settlements in Connecticut, Rhode Island, and New Haven.

8. Indian and Dutch encroachments.

Fffect: Pequod War; New England Confederacy.

§ 3. Essentials in International

Relations at Home and

Abroad. - 1620-1763.

1. Colonies versus Indians.

Effect : Civilization by Eng- 
lish; King Philip's War, 1675.

2. Continental wars extend to New France and New England.

Effect: King William's War; Queen Anue's IVar; King George's War.

3. Aggressive action towards colonial charters.

Effect: "Defence of the New England Charters," 1721.

4. Growing rivalry between English and French over the "gateway of the West."

Effect: Colonies share in the Seven Years' War.

5. Fall of Quebec.

Effect : French excluded from the Continent by Peace of Paris, 1763.

\$4. Essentials in the Revolution. - 1763-1783.

I. Discontext with Royal GovERNMENT. - 1763-1775.

1. Restrictions on commerce and manufactures.

Effect : Revolt against Navigation Acts by smuggling.

2. Writs of assistance and Stamp Act.

Effect : Stamp Act ; Congress demands redress, 1765.

3. Repeal of Stamp Act; Declaratory Act; Townshend Act; Tea Tax.

Effect: Principles of "taxation without representation" inroked; Boston 'TeaParty.

4. Aggressive acts of standing army.

Effect: Boston Massacre.

5. Preliminaries of the Revolution.

Effres: Committees of Correspondence; Committees of Safety.

6. The four intolerable acts.

Effect : (1) First Continental
Congress ; (2) Provincial Congresses; (3) Massachusetts boycotted.

7. British regulars attempt to break colonial military preparations.

Effect: Revolutionary War breaks out.

8. Investment of Bostou.

Effect: Battle of Bunker Hill.

9. Second Continental Congress.

Effect : Assumption of natioual powers for common defence.

II. Struggle to gain IndependENCE, - 1776-1783.

1. Spirit of separation (Virginia Bill of Rights). 1776.

Effect : Declaration of Independence, July 4, 1776.

2. Hopelessness of reconciliation.

Effect : Continuance of the war.

3. Campaign at Saratoga a turningpoint.

Effect: The French alliance.

4. Southern campaigns.

Effect: Defeat of Cornwallis.

5. American commissioners arrange treaties: Provisional Treaty, 1782 ; 'Treaty of $\mathrm{Pa}$ ris, 1783 .

Effect : Final independence of United States of America.

$\S 5$. Essentials in Constitution Building. - 1783-1790.

I. Struggle for Union in A

National Governyent. 1783-1787.

1. Necessity for frame of government.

Effect: Plans for Confederation, 1776-1781 ; Operation of Articles of Confederation, 1781-1787.

2. Problem of governing territory.

Effect: Northwest Ordinance of $178 \%$.

3 Financial weakness. 
Effect : Constitutional Convention, 1787 .

II. Development of a ConstiTutional Government. 1787-1790.

1. State sovereignty develops conflicting interests and opinions.

Effect : Three great compromises of the Constitutional Convention.

2. Final struggle between Articles of Confederation and Constitution of United States, 1787-1790.

Effect: Ratification.

\$6. Essentials in the Development of National Feeling. - 1790-1825.

1. Hamilton's financial policy versus Jefferson's opposition.

Effect: Federalism ; Republicanism.

2. Maintenance of domestic order.

Effect : Suppression of Whiskey Rebellion.

3. Jay's Treaty and its effect upon France.

Effect : American policy towards foreign nations influenced by Washington's Farewell Address, 1797.

4. Alien and Sedition $A$ cts.

Effect : Fall of Federal Party.

5. Power of Democratic-Republicanism.

Effect: International relations (Louisiana, Tripoli, " Chesapeake").

6. Question of neutral rights with France and England.

Effect : War of 1812.

7. Rapid settlement of the West.

Effect : New States.

8 Growing demand for nationalization.

Effect: Supreme Court decisions upon bank (1/cCulloch v. Maryland), States, etc.
9. Our policy towards the Americas.

Effect : Independence of Spanish colonies; Florida treaty.

10. Resistance to European intervention; Holy Alliance.

Effect : Russian treaty; Monroe Doctrine, 1823.

§ 7. Essentials in the Growth of Sectional Feeling.

1. Slavery.

Effect: Development of doctrine of State rights; Missouri Compromise.

2. Divergence of interests in the sections.

Effect : Rapid growth of North and South.

3. 'Tariff question.

Effect: Yielding of the principle of protection.

4. Question of nullification.

Effect: Jackson's attitude.

5. Mexican War.

Effect : Acquisition of Texas and California.

6. Repeal of Missouri Compromise.

Effect : Growth of antislavery sentiment.

7. Efforts of Soutl for more slave territory.

Effect : Compromises of 1850 ; Cuban question.

8. The Dred Scott Case. 1857.

Effect : Party fecling.

9. Campaign of 1860 .

Effect: Secession and formation of the Confederate States of America.

\section{$\S 8$. Essentials in the $W$ ar of the} Rebellion. - 1861-1865.

1. Firing on Fort Sumter.

Effect: Arousal of North to the defence of the Union.

2. Fears of foreign intervention.

Effect: The Trent affair; Seward's diplomacy ; invasion of Mexico by Napoleon III. 
3. Importance of salvation of border States.

Effect: Campaigns of 1862.

4. What to do with slavery.

Effect: "Contraband of war ;" Emancipation Proclamation, $1862,1863$.

5. Attempted invasion of the North.

Effect : Gettysburg.

6. The "Hammering Campaign."

Effect: Appomattox; peace and amnesty, April 9, 1865.

§ 9. Essentials in Reconstruction. 1864-1877.

1. Military government.

Issue: Carpet-bag government and plundering of exhausted South.

2. Thirteenth Amendment. 1865.

Issue : A bolition of slavery.

Fourteenth Amendment. 1866.

Effect: The negro made a citizen; validity of war debt established; Confederate debt repudiated; disfranchisement of whites of South followed by final removal of political disabilities.

Fifteenth Amendment. 1870.

Effect: Negro suffrage; tissue ballot; registration laws depriving negro suffrage; Ku-Klux Klan.
3. Quarrel between executive and Congress.

Effect: Civil Rights Bill; Tenure of Office Act; impeachment of President.

4. Election of Hayes.

Effect : Electoral Commission ; withdrawal of military from the South and final restoratiou of local self-goverument.

$\S 10$. Essentials in Social and Economic Discussions since the Civil War.

1. Payment of war debt.

Issue: Public credit strengthened; bonds appreciated; specie payments resumed.

2. Building of Pacific railroads.

Issue: New States ; rapid development of the West; land speculations.

3. Panic of 1873.

Issue: Attempted inflation.

4. Immigration.

Issue : Restriction of Chinese.

5. Free trade revived.

Issue: Morrison Bill; Mills Bill ; Wilson Bill.

6. Money questions.

Issue : Labor agitation, culmination in campaign of 1896. 


\section{APPENDIX C}

\section{TEXT OF THE HABEAS CORPUS ACT, 1679}

As Act for the better secureing the Liberty of the Subject and for Prevention of Imprisonments beyond the Seas.

I. Whereas great Delayes have beene used by Sheriffes Goalers and other Officers to whose Custody any of the Kings Subjects have beene committed for criminall or supposed criminall Matters in makeing Returnes of Writts of Habeas Curpus to them directed by standing out an Alias and Pluries Habeas Corpus and sometimes more and by other shifts to avoid their yeilding Obedience to such Writts contrary to their Duty and the knowne Lawes of the Land whereby many of the Kings Subjects have beene and hereafter may be long detained in Prison in such Cases where by Law they are baylable to their great charge and vexation. For the prevention whereof and the more speedy Releife of all persons imprisoned for any such criminall or supposed criminall Matters Bee it enacted by the Kings most Excellent Majestie by and with the Advise and Consent of the Lords Spirituall and Temporall and Commons in this present Parlyament assembled and by the authoritie thereof That whensoever any person or persons shall bring any Habeas Corpus directed unto any Sheriffe or Sheriffes Gaoler Minister or other Person whatsoever for any person in his or their Custody and the said Writt shall be served upon the said Officer or left at the Goale or Prison with any of the Under Officers Underkeepers or Deputy of the said Officers or Keepers that the said Officer or Officers his or their Under Officers Under-Keepers or Deputyes shall within Three dayes after the Service thereof as aforesaid (unlesse the Committment aforesaid were for Treason or Fellony plainely and specially expressed in the Warrant of Committment) [upon Payment or Tender of the Charges of bringing the said Prissoner to be ascertained by the Judge or Court that awarded the same and endorsed upon the said Writt not exceeding Twelve pence per Mile] and upon Security given by his owne Bond to pay the Charges of carrying backe the Prisoner if he shall bee remanded by the Court or Judge to which he shall be brought according to the true intent of this present Act and that he will not make any escape by 
the way make Returne of such Writt [or] bring or cause to be brought the Body of the Partie soe committed or restrained unto or before the Lord Chauncellor or Lord Keeper of the Great Seale of England for the time being or the Judges or Barons of the said Court from whence the said Writt shall issue or unto and before such other person [and] persons before whome the said Writt is made returnable according to the Command thereof, and shall [likewise then] certifie the true causes of his Detainer or Imprisonment unlesse the Committment of the said Partie be in any place beyond the distance of Twenty miles from the place or places where such Court or Person is or shall be resideing and if beyond the distance of Twenty miles and not above One hundred miles then within the space of Ten dayes and if beyond the distance of One hundred miles then within the space of Twenty dayes after such delivery aforesaid and not longer.

II. [AND to the intent that noe Sheriffe Goaler or other Officer may pretend ignorance of the import of any such Writt Bee it enacted by the Authoritie aforesaid That all such Writts shall be marked in this manner Per Statutum Tricesimo primo Caroli Secundi Regis and shall be signed by the person that awards the same] And if any person or persons shall be or stand committed or detained as aforesaid for any Crime unlesse for Treason or Fellony plainely expressed in the Warrant of Committment in the Vacation time and out of Terme it shall and may be lawfull to and for the person or persons soe committed or detained (other than persons Convict or in Execution) by legall Processe or any one [in] his or their behalfe to appeale or complaine to the Lord Chauncellour or Lord Keeper or any one of His Majestyes Justices [either] of the one Bench or of the other or the Barous of the Exchequer of the Degree of the Coife and the said Lord Chauncellor Lord Keeper Justices or Barons or any of them upon view of the Copy or Copies of the Warrant or Warrants of Committment and Detainer or otherwise upon Oath made that such Copy or Copyes were denyed to be given by such person or persons in whose Custody the Prisoner or Prisoners is or are detained are hereby authorized and required [upon Request made in Writeing by such person or persons or any on his her or their behalfe attested and subscribed by two Witnesses [that] were present at the delivery of the same] to award and grant an IIabeas Corpus under the Seale of such Court whereof he shall then be one of the Judges to be directed to the Officer or Officers in whose Custodie the Party soe committed or detained shall be returnable immediate before the said [Lord Chauncellor or] Lord Keeper or such Justice Baron or any other Justice or Baron of the Degree of the Coife of any of the said Courts and upon Service thereof as aforesaid the Officer or Officers his or their Under-Officer or Under Officers Under 
Keeper or Under Keepers or [their] Deputy in whose custodie the Partie is soe committed or detained shall within the times respectively before limitted [bring such Prisoner or Prisoners] before the ssd Lord Chauncellor or Lord Keeper or such Justices Barons or one of them [before whome the said Writt is made returnable and in case of his absence before any other of them] with the Returne of such Writt and the true Causes of the Committment and Detainer and thereupon within two dayes after the Partie shall be brought before them the said Lord Chauncellor or Lord Keeper or such Justice or Baron before whome the Prisoner shall be brought as aforesaid shall discharge the said Prisoner from his Imprisonment takeing his or their Recognizance with one or more Suretie or Sureties in any summe according to their discretions haveing reguard to the quality of the Prisoner and natnre of the Offence for his or their appearance in the Court of Kings Bench the Terme following or at the next Assizes Sessions or Generall Goale-Delivery of and for such County City or Place where the Committment was or where the Offence was committed or in such other Court where the said Offence is properly cognizable as the Case shall require and then shall certifie the said Writt with the Returne thereof and the said Recognizance or Recognizances into the said Court where such Appearance is to be made unlesse it shall appeare unto the said Lord Chauncellor or Lord Keeper or Justice or Justices [or] Baron or Barons that the Party soe committed is detained upon a legall Processe Order or Warrant out of some Court that hath Jurisdiction of Criminall Matters or by some Warrant sigued and sealed with the Hand and Seale of any of the said Justices or Barons or some Justice or Justices of the Peace for such Matters or Offences for the which by the Law the Prisoner is not Baileable.

III. [Provided alwayes and bee it enacted That if any person shall have wilfully neglected by the space of two whole Termes after his Imprisonment to pray a Habeas Corpus for his Enlargement such person soe wilfully neglecting shall not have any IIabeas Corpus to be granted in Vacation time in pursuance of this Act.]

IV. AND bee it further enacted by the Authoritie aforesaid That if any Officer or Officers his or their Under-Officer or Under-Officers Under-Keeper or Under-Keepers or Deputy shall neglect or refuse to make the Returnes aforesaid or to bring the Body or Bodies of the Prisoner or Prisoners according to the Command of the said Writt within the respective times aforesaid or upon Demand nade by the Prisoner or Person in his behalfe shall refuse to deliver or within the space of Six houres after demand shall not deliver to the person soe demanding a true Copy of the Warrant or Warrants of Committment and Detayner of such Prisoner, which he and they are hereby required to 
deliver accordingly all and every the Head Goalers and Keepers of such Prisons and such other person in whose Custodie the Prisoner shall be detained shall for the first Offence forfeite to the Prisoner or Partie grieved the summe of One hundred pounds and for the second Offence the summe of Two hundred pounds and shall and is hereby made incapeable to hold or execute his said Office, the said Penalties to be recovered by the Prisoner or Partie grieved his Executors or Administrators against such Offender his Executors or Administrators by any Action of Debt Suite Bill Plaint or Information in any of the Kings Courts at Westminster wherein noe Essoigne Protection Priviledge Injunction Wager of Law or stay of Prosecution by Non vult ulterius prosequi or otherwise shall bee admitted or allowed or any more then one Imparlance, and any Recovery or Judgement at the Suite of any Partie grieved shall be a sufficient Conviction for the first Offence and any after Recovery or Judgement at the Suite of a Partie grieved for any Offence after the first Judgement shall bee a sufficient Conviction to bring the Officers or Person within the said Penaltie for the second Offence.

V. AxD for the prevention of unjust vexation by reiterated Com. mittments for the same Offence Bee it enacted by the Authoritie aforesaid That noe person or persons which shall be delivered or sett at large upon any Habeas Corpus shall at any time here after bee againe imprisoned or committed for the same Offence by any person or persons whatsoever other then by the legall Order and Processe of such Court wherein he or they shall be bound by Recognizance to appeare or other Court haveing Jurisdiction of the Cause and if any other person or persons shall knowingly contrary to this Act recommitt or imprison or knowingly procure or cause to be recommitted or imprisoned for the same Offence or pretended Offence any person or persons delivered or sett at large as aforesaid or be knowingly aiding or assisting therein then he or they shall forfeite to the Prisoner or Partie grieved the summe of Five hundred pounds Any colourable pretence or variation in the Warrant or Warrants of Committment notwithstanding to be recovered as aforesaid.

VI. Provided alwayes and bee it further enacted That if any person or persons shall be committed for High Treason or Fellony plainely and specially expressed in the Warrant of Committment upon his Prayer or Petition in open Court the first Weeke of the Terme or first day of the Sessions of Oyer and Terminer or Generall Goale Delivery to be brought to his Tryall shall not be indicted sometime in the next Terme Sessions of Oyer and Terminer or Generall Goale Delivery after such Committment it shall and may be lawfull to and for the Judges of the Court of Kings Bench and Justices of Oyer and Terminer or Generall Goale Delivery and they are hereby required 
upon motion made to them in open Court the last day of the Terme Sessions or Goale-Delivery either by the Prisoner or any one in his behalfe to sett at Liberty the Prisoner upon Baile unlesse it appeare to the Judges and Justices upon Oath made that the Witnesses for the King could not be produced the same Terme Sessions or Generall Goale-Delivery. And if any person or persons committed as aforesaid upon his Prayer or Petition in open Court the first weeke of the Terme or first day of the Sessions of Oyer and Terminer or Generall Goale Delivery to be brought to his Tryall shall not be indicted and tryed the second Terme Sessions of Oyer and Terminer or Generall Goale Delivery after his Committment or upon his Tryall shall be acquitted he shall be discharged from his Imprisonment.

VII. [Provided alwayes That nothing in this Act shall extend to discharge out of Prison any person charged in Debt or other Action or with Processe in any Civill Cause but that after he shall be discharged of his Imprisonment for such his Criminall Offence he shall be kept in Custodie according to Law for such other Suite.]

VIII. Provided alwaies and bee it enacted by the Persons comAuthoritie aforesaid That if any person or persons Sub- mitted for crimject of this Realme shall be committed to [any] Prison inal matter not or in Custodie of any Officer or Officers whatsoever for but by Habeas any Criminall or supposed Criminall matter That the Corpus or other said person shall not be removed from the said Prison and Custody into the Custody of ally other Officer or Officers unlesse it be by Habeas Corpus or some other Legall Writt or where the Prisoner is delivered to the Constable or other inferiour Officer to carry such Prisoner to some Common Goale or where any person is sent by Order of any Judge of Assize or Justice of the Peace to any common Worke-house or House of Correction or where the Prisoner is removed from one'Prison or place to another within the same County in order to his or her Tryall or Discharge in due course of Law or in case of suddaine Fire or Infection or other necessity] and if any person or persons shall after such Committment aforesaid make out and signe or countersigne any Warrant or Warrants for such removeall aforesaid contrary to this Act as well he that nakes or signes or countersignes such Warrant or Warrants as the Officer or Officers that obey or execute the same shall suffer and incurr the Paines and Forfeitures in this Act before-mentioned both for the first and second Offence respectively to be recovered in manner aforesaid by the Partie grieved.

Penalty. 
Proviso for application for and granting Habeas Corpus in vacationtime.

Lord Chancellor, \&c., unduly denying Writ;

Penalty to Party $£ 500$. Undue denial of Writ.

No Subject to be sent Prisoner into Scotland, \&e., or any Parts beyond the Seas.

Persons 80 imprisoned may maintain Action against the Person committing or otherwise acting in respect thereof, as herein mentioned.
IX. Provided alsoe and bee it further enacted by the Anthoritie aforesaid That it shall and may be lawfull to and for any Prisoner and Prisoners as aforesaid to move and obtaine his or their Habeas Corpus as well out of the High Court of Chauncery or Court of Exchequer as out of the Courts of Kings Bench or Common Pleas or either of them And if the said Lord Chauncellor or Lord Keeper or any Judge or Judges Baron or Barons for the time being of the Degree of the Coife of any of the Courts aforesaid in the Vacation time upon view of the Copy or Copies of the Warrant or Warrants of Committment or Detainer or upon Oath made that such Copy or Copyes were denyed as aforesaid shall deny any Writt of Habeas Corpus by this Act required to be granted being moved for as aforesaid they shall severally forfeite to the Prisoner or Partie grieved the summe of Five hundred pounds to be recovered in manner aforesaid.

X. Axp bee it enacted and declared by the Authority aforesaid That an Habeas Corpus according to the true intent and meaning of this Act may be directed and runn into any County Palatine The Cinque Ports or other priviledged Places within the Kingdome of England Dominion of Wales or Towne of Berwicke upon Tweede and the Islands of Jersey or Guernsey Any Law or Usage to the contrary notwithstanding.

XI. AND for preventing illegall Imprisonments in Prisons beyond the Seas. Bee it further enacted by the Authoritie aforesaid That noe Subject of this Realme that now is or hereafter shall be an Inhabitant or Resiant of this Kingdome of England Dominion of Wales or Towne of Berwicke upon Tweede shall or may be sent Prisoner into Scotland Ireland Jersey Gaurnsey Tangeir or into any Parts Garrisons Islands or Places beyond the Seas which are or at any time hereafter [shall be] within or withont the Dominions of His Majestie His Heires or Successors and that every such Imprisonment is hereby enacted and adjudged to be illegal and that if any of the said Subjects now is or hereafter shall bee soe imprisoned [every such person and persons soe imprisoned] shall and may for every such Imprisonment maintaine by virtue of this Act an Action or Actions of false Imprisonment in any of His Majestyes Courts of Record against the person or persons by whome he or she shall be soe committed detained imprisoned sent Prisoner or transported contrary 
to the true meaning of this Act and against all or any person or persons that shall frame contrive write seale or countersigne any Warrant or Writeing for such Cornmittment Detainer Imprisonment or Transportation or shall be adviseing aiding or assisting in the same or any of them and the Plaintiffe in every such Action shall have Judgement to recover his treble Costs besides Damages Treble Costs which Damages soe to be given shall not be lesse then and Damages. Five hundred pounds. In which Action noe delay stay or stopp of Proceeding by Rule Order or Command nor noe Injunction Protection or Priviledge whatsoever nor any more then one Imparlance shall be allowed [excepting such Rule of the Court wherein the Action shall depend made in open Court as shall bee thought in Justice necessary for speciall cause to be expressed in the said Rule] and the person or persons who shall knowingly frame contrive write seale or countersigne any Warrant for such Committment Detainer or Transportation or shall soe committ detaine imprison or trausport any person or persons contrary to this Act or be any wayes adviseing aiding or assisting therein being lawfully convicted thereof shall be disabled from thenceforth to beare any Office of Trust or Proffitt within the said Realme of England Dominion of Wales or Towne of Berwicke upon Tweede or any of the Islands Territories or Dominions thereunto belonging and shall incurr and sustaine the Paines Penalties and Forfeitures limitted ordained and provided in the Statute of Provision and Premunire made in the Sixteenth yeare of King Richard the Second and be incapeable of any Pardon from the King His Heires or Successors of the said Forfeitures And be incapable of Pardon. Losses or Disabilities or any of them.

XII. [Provided alwayes That nothing in this Act shall extend to give benefitt to any person who shall by Contract in writeing agree with any Merchant or Owner of any Plantation or other person whatsoever to be transported to any parts beyond Seas and receive earnest upon such Agreement although that afterwards such person shall renounce such Contract.]

XIII. Provided alwayes and bee it enacted That if For Transany person or persons lawfully convicted of any Felony portation of shall in open Court pray to be transported beyond the victed of felSeas and the Court shall thinke fitt to leave him or them ony and in Prison for that purpose such person or persons nay transported. 
Proviso respecting Imprisonment of Persons before 1 st June 1679.

be transported into any parts beyond the Seas. This Act or any thing therein contained to the contrary notwithstanding.

XIV. Provided alsoe and bee it enacted That nothing herein contained shall be deemed construed or taken to extend to the Imprisonment of any person before the First day of June One thousand sixe hundred seaventy and nine or any thing advised procured or otherwise done relateing to such Imprisonment. Any thing herein contained to the contrary notwithstanding.

XV. Provided alsoe That if any person or persons at any time resiant in this Realme shall have committed any Capitall Offence in Scotland or Ireland or any of the Islands or Forreigne Plantations of the King His Heires or Successors where he or she ought to be tryed for such Offence such person or persons may be sent to such place there to receive such Tryall in such manner as the same might have beene used before the makeing of this Act Any thing herein contained to the contrary notwithstanding.

XVI. Provided alsoe and bee it enacted That noe person or persons shall be sued impleaded molested or troubled for any Offence against this Act unlesse the Partie offending be sued or impleaded for the same within Two yeares at the most after such time wherein the Offence shall be committed [in case the partie grieved shall not be then in Prison and if he shall be in Prison then within the space of $T$ wo yeares] after the decease of the Person imprisoned or his or her delivery out of Prison which shall first happen.

XVII. AND to the intent noe person may avoid his Tryall at the Assizes or Generall Goale-Delivery by procureing his Removeall before the Assizes at such time as he cannot be brought backe to receive his Tryall there Bee it enacted That after the Assizes proclaimed for that County where the Prisoner is detained noe person shall be removed from the Common Goale upon any Habeas Corpus granted in pursuance of this Act but upon any such Habeas Corpus shall be brought before the Judge of Assize in open Court who is thereupon to doe what to Justice shall appertaine.

After Assizes Persons detained may have Habeas Sorpus.
XVIII. Provided nevertheless That after the Assizes are ended any person or persons detained may have his or her Habeas Corpus according to the Direction and Intention of this Act. 
XIX. Axd bee it also enacted by the Authoritie aforesaid That if any Information Suite or Action shall be brought or exhibited against any person or persons for any Offence committed or to be committed against the Forme of this Law it shall be lawfull for such Defendants to pleade the Generall Issue that they are not guilty or that they owe nothing and to give such speciall nuatter in Evidence to the Jury that shall try the same which matter being pleaded had beene good and sufficient matter in Law to have discharged the said Defendant or Defendants against the said Information Suite or Action and the said matter shall be then as availeable to him or them to all intents and purposes as if he or they had sufficiently pleaded sett forth or alledged the same matter in Barr or Discharge of such Information Suite or Action.

XX. Axv because many times Persons charged with Petty Treason or Felony or as Accessaries thereunto are committed upon Suspicion onely whereupon they are Baileable or not according as the Circumstances makeing out that Suspicion are more or lesse weighty which are best knowne to the Justices of Peace that committed the persons and have the Examinations before them or to other Justices of the Peace in the County Bee it therefore enacted That where any person shall appeare to be committed by any Judge or Justice of the Peace and charged as Accessary before the Fact to any Petty Treason or Felony or upon Suspicion thereof or with Suspicion of Petty Treason or Felony which Petty Treason or Felony shall be plainely and specially expressed in the Warrant of Committment that such Person shall not be renoved or bailed by vertue of this Act or in any other manner then they might have beene before the makeing of this Act.

The Statutes of the Realm, V. 935-938. $31^{\circ}$ Car. II. c. 2. 


\section{APPENDIX D}

\section{LIST OF AUTHORS CITED}

This list includes every work from which citations have been made, in the edition used. The names of the publishers are inserted for all copyright material; and the thanks expressed in the Preface for the privilege of using the extracts are here gratefully repeated.

Charles Francis Adams. Imperialism and the Tracks of our Forefathers. Boston, Dana Estes \& Co., 1899.

John Adams. Works. (Edited by Charles Francis Adams.) 10 vols. Boston, 1850-1856.

John Adams and Abigail Adams. Familiar Letters during the Revolution. (Edited by Charles Francis Adams.) New York, Hurd \& Houghton, 1876.

John Quincy Adams. Memoirs. (Edited by Charles Francis Adams). 12 vols. Philadelphia, Lippincott, 1874-1877.

American Historical Review. 5 vols. New York, Macmillan, 1896-1900. Anonymous. America's Appeal to the Impartial World: wherein the Rights of Americans as Men, British Subjects, and as Colonists . . are Stated and Considered. Hartford, 1775.

Anonymous. A Plain State of the Argument between Great Britain and her Colonies. London, 1775.

Anonymous. Proposals for Uniting the English Colonies on the Continent of America so as to enable them to act with Force and Vigour against their Enemies. London, 1757.

Walter Bagehot. English Constitutional History. Oxford, Clarendon Press, 1891.

Frederic Bancroft. Life of William $H$. Seward. 2 vols. New York, Harper, 1900.

George Bancroft. A History of the United States. (Anthor's Last Revision.) 6 vols. New York, Appleton, 1883-1885.

Thomas Hart Benton. Historical and Legal Examination of ... the Decision of the Supreme Court of the United States in the Dred Scott Case. New York, Appleton, 1851.

Horace Binney. An Inquiry into the Formation of Washington's Farewell Address. Philadelphia, Parry \& Macmillan, 1859. 
William Blackstone. Commentaries. (Edited by William Draper Lewis.) 4 books. Philadelphia, Welsh, Rees \& Co., 1897.

James G. Blaine. Twenty Years of Congress, 1861-1881. 2 vols. Norwich, Henry Bill Publishing Co., 1884.

Charles Borgeaud. Adoption and Amendment of Constitutions in Enrope and America. ('Translated by Charles D. Hazen.) New York, Macmillan, 1895.

Charles Borgeaud. The Rise of Modern Democracy in Old and New Eng. land. (Translated by Mrs. Birkbeck Hill.) London, Swan, Sonnenschein \& Co., and New York, Scribner, 1894.

Emile Boutmy. The English Constitution. ('Translated by Isabel M. Eaden.) London and New York, Macmillan, 1891,

James Bryce. The American Commonwealth. Abridged edition. New York, Macmillan, 1896.

Edmund Burke. Works. 9 vols. Boston, 1839.

Gilbert Burnet. History of His Own Time. 2 vols. London, 1724-1734.

Jacob Burnet. Notes on the Early Settlement of the Northwestern Teritory. New York, 1847.

Thomas Carlyle. Oliver Cromwell's Letters and Speeches, with Elucidations. 4 vols. New York, Scribner, 1897.

Francis Bicknell Carpenter. Six Months at the White House with Abraham Lincoln. New York, Hurd \& Houghton, 1866.

Edward Channing. Students' History of the United States. New York, Macmillan, 1898.

Jeremiah Chaplin. Words of our Hero, Ulysses S. Grant. Boston, Lothrop, 1885.

Salmon Portland Chase. A Sketch of the History of Ohio. Cincinnati, 1833. William Cobbett. The Parliamentary History of England, from the Earliest Period to the Year 1803. 36 vols. London, 1806-1820. (Usually called " Hansard's Parliamentary History.")

Charles Carleton Coffn. Freedom Triumphant: Fourth Period of the War of the Rebellion, Sept., 1864, to close. New York, Harper, 1891.

Congressional Globe. 109 vols. Washington, 1835-1873.

Congressional Record. 33 vols. in 192 . Washington, 1873-1900.

Thomas M. Cooley. The General Principles of Constitutional Law. Boston, Little, Brown \& Co., 1891.

Bartholomew de Cotton. Mistoria Anglicana. (Edited by Henry Richards Luard.) London, Longmans, 1859.

Edward Shepherd Creasy. Rise and Progress of the English Constitution. New York, Appleton, 1859.

Benjamin Robbins Curtis. Reports of Decisions in the Supreme Court of the United States. With Notes and a Digest. 23 vols. Boston, Little \& Brown, 1881.

George Ticknor Curtis. Constitutional History of the United States. New York, Harper, 1889. 
William Parker Cutler and Julia Perkins Cutler. Life, Journals, and Correspondence of Rev. Manasseh Cutler. 2 vols. Cincinnati, Robert Clarke \& Co., 1888.

Richard Henry Dana. Wheaton's Elements of International Law. Boston, Little, Brown \& Co., 1866.

Albert Venn Dicey. Lectures Introductory to the Study of the Law of the Constitution. London, Macmillan, 1885.

Jeremiah Dummer. A Defence of the New England Charters. London, 1721.

William Archibald Dunning. Essays on the Civil War and Reconstruction and Related Topics. New York, etc., Macmillan, 1898.

Edinburgh Review. 192 vols. London, Longmans, 1806-1900.

H. St. Clair Fielden. A Short Constitutional History of England. (Edited by W. Gray Etheridge.) London, Blackwell; Boston, Ginn, 1895.

Sidney George Fisher. The Evolution of the Constitution of the United States. Philadelphia, Lippincott, 1897.

John Fiske. The American Revolution. 2 vols. Boston, Houghton, Mifflin \& Co., 1892.

John Fiske. The Critical Period of American History, 1783-1789. Boston, Houghton, Mifflin \& Co., 1899.

Henry Jones Ford. The Rise and Growth of American Politics. New York, Macmillan, 1898.

Paul Leicester Ford. Pamphlets on the Constitution. Brooklyn, P. L. Ford, 1888.

John Forster. Eminent British Statesmen. London, 1837.

William Forsyth. History of 'Trial by Jury. London, 1852.

Sir John Fortescue. De Laudibus Legum Angliae. London, 1741.

Edward Augustus Freeman. Historical Essays. Fourth Series. London and New York, Macmillan, 1892.

Samuel Rawson Gardiner. Constitutional Documents of the Puritan Revolution, 1628-1660. 2 vols. Oxford, Clarendon Press, 1889.

Samuel Rawson Gardiner. Student's History of England. London and New York, Longmans, 1895.

Franklin Henry Giddings. Democracy and Empire. New York, Macmillan, 1900.

Daniel Coit Gilman. James Monroe. (American Statesmen Series.) Boston, Houghton, Mifflin \& Co., 1883.

William Ewart Gladstone. Gleanings of Past Years. 7 vols. London, John Murray; New York, Scribner, 1878.

Rudolph von Gneist. History of the English Parliament. London, Clowes ; New York, Putnam, 1892.

Ulysses Simpson Grant. Personal Memoirs. 2 vols. New York, Charles L. Webster \& Co., 1886.

Horace Greeley. The American Conflict. 2 vols. Hartford, O. D. Case \& Co., 1864-1867. 
John Richard Green. A Short History of the English People. London, Macmillan, 1897.

Francois Pierre Guillaume Guizot. The History of Civilization, from the Fall of the Roman Empire to the French Revolution. (Edited by C. S. Henry.) 4 vols. New York, Appleton, 1897.

Henry Hallam. The Constitutional II istory of England, from the Accession of Henry VII. to the death of George II. 3 vols. London, 1855.

Henry Hallam. View of the State of Europe during the Middle Ages. 2 vols. New York, 1843.

Alexander Hamilton. Works. (Edited by Henry Cabot Lodge.) 9 vols. New York, Putnam, 1885-1886.

Hansard's Parliamentary History. See William Cobbett.

John Innes Clark Hare. American Constitutional Law. 2 vols. Boston, Little, Brown \& Co., 1889.

Harper's New Monthly Magazine. 100 vols. New York, Harper, 18501900.

Albert Bushnell Hart. Formation of the Union, 1750-1829. New York, etc., Longmans, 1896.

Albert Bushnell Hart. Introduction to the Study of Federal Government. (Harvard Historical Monograph, No. 2.) Boston, Ginn, 1891.

Burke Aaron Hinsdale. The Old Northwest. New York, Townsend MacConn, 1888.

Henry Hitchcock. American State Constitutions : a Study of their Growth. New York, Putnam, 1887.

George Frisbie Hoar. No Constitutional Power to Conquer Foreign Nations. Boston, Dana Estes \& Co., 1899.

George Frisbie Hoar. Oration delivered at the Celebration of the Centennial of the Founding of the Northwest at Marietta, Ohio, April 7, 1888. Washington, 1888.

Hermann von Holst. The Constitutional and Political History of the United States. (Translated by J.J.Lalor and A. B. Mason.) 8 vols. Chicago, Callaghan \& Co., 1889-1892.

James K. Hosmer. Anglo-Saxon Freedom. New York, Scribner, 1890.

John Codman Hurd. The Theory of our National Existence. Boston, Little, v Brown \& Co., 1881.

Rollin C. Hurd. A Treatise on the Right of Personal Liberty, and the Writ of Habeas Corpus. Albany, W. C. Little \& Co., 1876.

John Alexander Jameson. A Treatise on Constitutional Conventions. Chicago, Callaghan \& Co., 1887.

John Franklin Jameson. Essays in the Constitutional History of the United States in the Formative Period. Boston, Houghton, Miftin \& Co., 1889.

Thomas Jefferson. Writings, being his Autobiography, Correspondence, and other Writings. (Edited by II. A. Washington.) 9 vols. Washington, 1853-1854.

Alexander Johnston. The United States : its Ilistory and Constitution. New York, Scribner, 1889. 
Journal of the First Congress of the American Colonies. (Edited by Lewis Cruger.) New York, E. Winchester, 1845.

Journals of Congress. Contuining the Proceedings, 1774-1788. 13 vols. Published by order of Congress, Philadelphia, 1777-1788.

Sir William Keith. Tuo Paper's on the Subject of Taxing the British Colonies in America. London, 1767.

William Edward Hartpole Lecky. History of England in the Eighteenth Century. (Loudon, Longmans.) 6 vols. New York, Appleton, 1882.

Abraham Lincoln. Coinplete Works. (Edited by John G. Nicolay and John Hay.) 2 vols. New York, Century Co., 1894.

George Livermore. An Historical Research respecting the Opinions of the Founders of the Republic on Negroes as Slaves. (Massachnsetts Historical Society.) Boston, John Wilsop, 1862.

Henry Cabot Lodge. George Washington. (American Statesmen Series.) 2 vols. Boston, Hougliton, Mifflin \& Co, 1897.

Henry Cabot Lodge. The Story of the Revolution. 2 vols. New York, Scribner, 1898.

John Davis Long. Address before the Home Market Club, February, 1899. Boston, Home Market Club, 1899.

James Russell Lowell. Prose Works. 5 vols. Boston, Houghton, Mifflin \& Co., 1892.

Thomas Babington Macaulay. Critical, Historical, and Miscellaneous Essays. (London and New York, Longmans.) 6 vols. New York, Hurd \& Houghton, 1866.

Thomas Babington Macaulay. History of England. (London and New York, Longmans.) 5 vols. Bostom, 1849. Also 8 vols. New York, Hurd \& Houghton, 1866.

Samuel W. McCall. Thaddeus Stevens. Boston, etc., Honghton, Miflin \& Co., 1899.

William McKinley, Speech delivered at the Home Market Club, February 16, 1899. Boston, Home Market Club, 1899.

Sir James Mackintosh. Mistory of England. 3 vols. Philadelphia, 18301833.

Andrew C. McLaughlin. Mistory of the American Nation. New York, Appleton, 1899.

John Bach McMaster. With the Fathers. New York, Appleton, 1897.

James Madison. Letters and other Writings. 4 vols. Philadelphia, Lippincott, 1865.

James Madison. Papers being his Correspondence and Reports of Debates. (Edited by Henry D. Gilpin.) 3 vols. Washington, 1840.

William of Malmesbury. English Chronicle. (Edited by J. A. Giles.) London, George Bell, 1883.

John Marshall. A Mistory of the Colonies planted by the English on the Continent of North America. Pliladelphia, 1824. 
Sir Thomas Erskine May. Constitutional History of England. (London and New York, Longunaus.) 2 vols. New York, 1887.

Dudley Julius Medley. A Student's Manual of English Constitutional History. Oxford, B. H. Blackwell, 1894.

Roger B. Merriman. Life of Thomas Cromwell. (MS.) [In the Library of Harvard University.]

John Torrey Morse, Jr. Abraham Lincoln. (American Statesmen Series.) Boston, Houghton, Mifflin \& Co, 1897.

John Torrey Morse, Jr. John Quincy Adams. Boston, Houghton, Miffliu \& Co., 1882 .

John Torrey Morse, Jr. Thomas Jefferson. (American Statesmen Series.) 2 vols. Boston, Houghton, Mifflin \& Co., 1897.

Elisha Mulford. The Nation: the Foundations of Civil Order and Political Life in the United States. New York, Hurd \& Houghton, 1870.

John G. Nicolay and John Hay. Abraham Lincoln: $a$ History. 10 vols. New York, Century Co., 1890.

Hezekiah Niles. Principles and Acts of the Revolution in America. (Reprint.) New York, A. S. Barnes \& Co., 1876.

Hezekiah Niles. The Weekly Register. 73 vols. Baltimore, 1812-1848.

James Otis. The Rights of the British Colonies Asserted and Proved. London, 1766.

The Outlook (weekly). New York, Outlook Co., 1897-

Francis Palgrave. The Rise and Progress of the English Commonwealth, Anglo-Saxon Period. 2 pts. London, 1832.

James Paterson. Commentaries on the Liberty of the Subject and the Laws of England relating to the Security of the Person. 2 vols. London, Macmillan, 1877.

Edward Lillie Pierce. Memoir and Letters of Charles Sumner. 2 vols. Boston, Roberts, 1893.

Political Science Quarterly. 14 vols. Boston, etc., Ginn, 1886-1899.

Sir Frederick Pollock and Frederic William Maitland. History of English Law before the Time of Edward I. 2 vols. Cambridge (Eng.), University Press; Boston, Little, Brown, \& Co., 1895.

Thomas Pownall. The Administration of the Colonies. Loudon, 1765.

Pulpit and Rostrum. Sermons, Orations, etc. 31 nos. New York, H. H. Lloyd, etc., 1858-1866.

David Ramsay. The History of the American Revolution. 2 vols. Philadelphia, 1789.

Carman Fitz Randolph. Notes on the Foreign Policy of the United States, sugycsted by the War with Spain. New York, De Vinne Press, 1898.

Cyril Ransome. Advanced History of England. London, Rivingtons; New York, Macmillan, 1896.

William Fiddian Reddaway. The Monroe Doctrine. Cambridgo (Eng.), University Press, 1898. 
James Ford Rhodes. History of the United States from the Compromise of 1850. 4 vols. New York, Macmillan, 1900.

James D. Richardson, Editor. Messages and Papers of the Presidents, 1789-1797. 10 vols. Washington, 1896-1899.

John Codman Ropes. The Story of the Civil War. 3 vols. New York, Putnam, 1898.

Christopher St. Germain. Doctor and Student; or, Dialogues between a Doctor of Divinity and a Student in the Laws of England. London, 1761.

John T. A. Sanborn. Report of the Decision of the Supreme Court of the United States in the Case of Dred Scott. Washington, 1857.

James Schouler. Constitutional Studies, State and Federal. 5 vols. New York, Dodd, Mead \& Co., 1897.

James Schouler. History of the United States of America under the Constitution. 5 vols. Washington, W. H. Morrison, 1882-1891.

Carl Schurz. American Imperialism. (Address before the University of Chicago, January 4, 1899.) Boston, Dana Estes \& Co., 1899.

George Spence. The Equitable Jurisdiction of the Court of Chancery. 2 rols. London, 1846-1849. Philadelphia, T. \& J. W. Johnson \& Co.

Statutes at Large, from Magna Charta to the End of the Last Parliament, 1761. 20 vols. (Edited by Owen Ruffhead.) London, 1763-1765.

Statutes of the Realm, printed by command of His Majesty, King George the Third. II vols. London, 1810-1821.

C. Ellis Stevens. Sources of the Constitution of the United States, considered in relation to Colonial and English History. New York, Macmillan, 1894.

Joseph Story. Commentaries on the Constitution of the United States. Boston, etc., 1833.

William Stubbs. The Constitutional History of England. 3 vols. Oxford, Clarendon Press, 1891.

William Stubbs. Select Charters and other Illustrations of English Constitutional History. Oxford, Clarendon Press, 1870.

William Graham Sumner. The Conquest of the United States by Spain. Boston, Dana Estes \& Co., 1899.

William Graham Sumner. History of Banking in the United States. 2 vols. New York, Journal of Commerce, 1896.

Ida M. Tarbell. Life of Abraham Lincoln. 2 vols. New York, McClure, Phillips \& Co., 1900.

Thomas Pitt Taswell-Langmead. English Constitutional History. London, Stevens \& Haynes; Boston, Houghton, Mifflin \& Co., 1896.

Hannis Taylor. Origin and Growth of the English Constitution. 2 vols. Boston, Houghton, Mifflin \& Co., 1889.

Francis Newton Thorpe. Constitutional History of the American People. New York, Harper, 1898.

Reuben Gold Thwaites. The Colonies, 1492-1750. New York, etc., Longmans, 1897. 
George Fox Tucker. The Monroe Doctrine. Boston, George B. Reed, 1885.

Josiah Tucker. A Letter from a Merchant in London to his Nephew in North America. London, 1766.

Robert Walsh. An Appeal from the Judgments of Great Britain respecting the United States of America. Philadelphia, etc., 1819.

George Washington. Writings. (Edited by Jared Sparks.) 12 vols. Boston, 1837. - Also (edited by W. C. Ford) 14 vols. New York, Putnam, 1889-1893.

Daniel Webster. Works. (Edited by Edward Everett.) 6 vols. Boston, 1851.

Pelatiah Webster. Remarks on a Pamphlet. Printed, 1784.

Roger of Wendover. Flowers of History. (Translated by J. A. Giles.) 2 vols. London, 1849.

Westel Woodbury Willoughby. The Supreme Court of the United States, its History and Influence in our Constitutional System. Baltimore, Johns Hopkins Press, 1890.

Henry Wilson. History of the Rise and Fall of the Slave Power in America. 3 vols. Boston, James R. Osgood, 1872-1877.

Justin Winsor. Narrative and Critical History of America. 8 vols. Boston, Houghton, Mifflin \& Co., 1887.

Theodore s. Woolsey. America's Foreign Policy. New York, Century Co., 1898. 



\section{INDEX}

The names of the authors of documents are in boldface. The titles of documents are in Small Capitals. The titles of books cited are in italies.

$\mathrm{A}^{\mathrm{B}}$ BBEYS, rights of founders, 19. Acir

CT OF SETTLKM ENT, text, 138-140 contemporary exposition, 140 ; critical comment, 140-141.

Adams, C. F., cited, $402,440$.

Adains, G. B., cited, 40.

Adams, John, on state governments, 170 ; Works, 173, 440; on Declaration of Independence, 188-191; Familia. Letters, 191, 440.

Adams, John Quincy, cited, 253; on the Monroe Doctrine, 323; Memoirs, $325,440$.

Adjournment, of Parliament, 86, 92 ; of colonial legislatures, 184; of Congress, $247,248,255$.

Agreement of thic People, text, 7985 ; critical conument, 100-114; a constitution, 83 ; fundamentals of, 84 .

Aids, imposition of, $13,14,44,67$; the three, 13; for common benefit, 44 .

Amendments, of Articles of Confederation, 215 ; to the Constitution, 261264, 373-375; how made, 258; limitation to, 259; not to be liasty, 295; Coffroth on, 375; Brown on, 376; Blaine on, 376; effect of Fifteenth on Fourteenth, 379 .

America, European control of, 322-326.

American Historical Review, 41, 285, 440.

American History Leaflets, 204, 245, 373.

Amnesty, to King Charles' adherents, 82.

Andros, Sir Edmund, in New England, 143.

Anonymous, Plain State of the Argument, 145, 440: Proposals for uniting the English Colonies, 147, 440; America's Appeal to the Impartial World, 150,440 .
Appointing power, under the Constitution, 255.

Apportionment, of requisitions, 209; of direct taxes, 245,251 ; of representation, $245,374$.

Arms, right to bear, 125, 261.

Army, control of, $86,208,212,250$; negroes in, 364-366. - See also Standing Army.

Articles of Confendration, text, 204-216 ; contemporary expositiol, 216-220; critical comment, 220-226.

Assizes, 14, 116.

Atlantic Monthly, 402.

Attainder, bill of, forbidden, 251, 252.

Attaint, writ of, 52 .

RAGEHOT, WAlter, cited, 31, 101, 440.

Bail, not to be excessive, $125,168,262$; right to, 115-116, 233.

Bancroft, Frederic, cited, 371, 440.

Bancroft. George, cited, 240, 440; on Dred Scott decision, 351.

Bankruptey, control of, 250 .

13artholomew de Cotton, on foreign military service, 45 ; Historia Anglicann, $45,441$.

Benevolences, forbidden, 67,70 ; exacted, 68 .

Benton, Thomas H., on Dred Scott decision, 349; Examination of the Dred Scott Case, 351, 440.

BILL of Rights, text, 122-132; contemporary exposition, 132; critical comment, 132-137; of Virginia, 166 ; of Northwest Territory, 233; of the United States, 261.

Billeting. - See Quartering.

Bills of eredit, of colonies, 147; control of $212,213,252$.

Binuey, Horace, cited, 309, 440. 
Blackstone, Sir William, cited, 54, 118, 140,441 .

Blaine, James G., on the reconstruction amendments, $376 ;$ Twenty Years of Congress, 380, 441.

Blyth, Joseph, on Washington's Farewell Address, 308.

Bollen, William, Journals of Congress, 164.

Borgeaud, Charles, cited, 111, 176, 441.

Boston Herald, 399, 401.

Boutiny, Emile, cited, 39, 441.

Brown,.J.S., on the Thirteenth Amendment, 376.

Bryce, James, cited, 177, 256, 282, 356, $381,441$.

Burgage, tenure, 17.

Burgess, J. W., cited, 411.

Burke, Edmund, cited, 27 ; on taxing colonies, 162; Speech on Conciliation, 162 ; Works, 162, 441.

Burnet, Gilbert, on Habeas Corpus Act, 117; History of His Own Times, 117, $132,140,441$; on Bill of Rights, 132; on Act of Settlement, 140.

Burnet, Jacob, cited, 240, 441.

CANADA, and the Confederation, 214. $\checkmark$ Capitation tax, to be apportioned 251.

Carlyle, Thomas, Life of Cromwell, 99, 441.

Carpenter, F. B., on the Emancipation Proclamation, 366 ; Six Months at the White House, 367, 441.

Carteret, Lord, letter to, 142.

Castle-guard, 16.

Census, decennial, 245.

Chamberlain, Mellen, cited, 164.

Chancery, king's, 51 .

Channing, Edward, cited, 180, 441.

Chaplin, Jeremiah, Words of our Hero, $366,441$.

Charles I., on the Petition of Right, 72; Speech, 72 ; amnesty to his adherents, 82.

Charters, of Henry I., 2; Magna Charta, 9; Confirmatio Chartarum, 43: of the Forest, 43 ; of New England, lost, 143,185 ; recovered, 143 ; rights of colonies under, 148, 149.

Chase, S. P., cited, 239, 441.

Chatham, Earl of, - See Pitt, William.

Chief Justice, at impeachment trials, 247.

Church, freed, 2, 10; of England, king to commune with, 138. - See also Religion.

Citizens, of other States, rights of, 205, 257 ; of the United States, negroes, $342,344,345,347$; who are, 316,347 ,
373 ; protection of, 374 ; state and national, 343,347 .

Civil cascs, jury trial in, 51, 168, 262.

Civil rights, ancient, to be respected, $13,15,128$; equal protection of, guaranteed, 374 ; in colonies, 397. - See also Personal liberty, Property, Religion.

Civil War, reunion, 358; disabilities resulting from, 374 ; debt honored, 374 ; Southern debt repudiated, 375.

Cleveland, Grover, cited, 334 .

Cobbett, William, Parliamentary History of England, 72, 79, 85, 441.

Cottin, C. C., cited, 441 .

Coffroth, A. H., on Thirteenth Amendnuent, 375 .

Coke, Sir Edward, cited, 27.

Colonies, New England charters, 143, 185 ; defended, 144 ; charges against, 144 ; control of $144,146,161,163$; union advised, 146 ; rights of legislation, 146; claim Magna Charta and rights of British subjects, 144, 147, 149, 156, 160 ; charter rights of, 142-150; taxation and representation, $156,159,160$, 161,162 ; grants by, 159, 162 ; petition Parliament, 164; grievances of, 184. - See also Cuba, Philippines, Porto Rico.

Commander-in-chief, 213 ; the president, 255.

Commerce, colonial, cut off, 185 ; control of, 207, 209, 250 ; uniform regulation of, 252 ; policy of the United States, 303.

Commissioners for Ecclesiastical Causes, illegal, 125.

Common pleas, court of, to be stationary, 14 .

Common tribute, forbidden, 3.

Commonwealth of England, government of, 85. - See also Council of State, Parliament, Lord Protector.

Confederation, Articles of, 201-216; objects of, 205; limitations of power of states in, 207; committee of the states, 212,214 ; to be perpetual and supreme, 215 ; amendment of, 215 ; ratification of, 215 ; Nortliwest Territory a part of, 234. - See also Congress of the Confederation.

Confinmatio Chartarum, text, 4345 ; contemporary exposition, 45 ; critical comment, 45-48.

Congress of the Confederation, organization, 206, 213: votes in, 207; immunities of members, 207 ; powers of, 209-214: majority in. 213 ; NortHwEST ORDINANCE, $228-236$; territorial delegate to, 233 . 
Congress, Continental, instructions to agents, 164 ; advises formation of state governments, 172, 173; DecLARATION OF INDEPENDKNCE, 183-188; Articles of Confederation, 204216.

Congress of the United States, organization, 245; elections, 245-247 ; sessions, 247, 255; quorum, 247 ; control over members, 247,248 ; journals, 248 ; adjournment, $247,248,255$; compensation, 248; immunities, 248; yeas and nays in, 248 ; members not eligible to office, 248 ; procedure of bills, 249 ; powers of, $249-251,257,258,373-$ 375 ; limitations, 251-252, 254, 261263 ; interpretation of powers of, 313; responsible for government of colonies, 394, 398. - See also House of Representatives, Senate.

Congressional Globe, 365, 366, 376, 441.

Congressional Record, 392, 441.

Constitution, defined, 148 .

Constitution of the United States, text, 245-264, 373-375; contemporary exposition, 264-273; critical comment, 273-283; why ordained, 245; how amended, 258; amendments to, 261264, 373-375; supreme law, 259, 315; when established, 260 ; Washington on, 294 ; implied powers of, 313 ; negroes not citizens under, 342,344 , 345 ; interpretation of, 343,344 ; slavery under, 345,350 ; does not extend to territories, 349 ; and equality, 352. - See also Congress, United States.

Contenement, 15, 145.

Contracts, obligations of, not to be impaired, 234, 252.

Cooley, T. M., cited, 276, 381, 441.

Copyrights and patents, laws for, 250 .

Cononation Oath and Charten of HENkY I., text, 1-5 ; contemporary exposition, 5-6; critical comment, 6-8.

Cotton. - See Bartholomew.

Council of State, appointment of, 81, 85, 92,93 ; powers of, $81,94,95$; term, 81 ; trial of, 92 ; to take oath, 97.

Courts, for trials upon certain writs, 14; common pleas to be stationary, 14; pleas of the crown, 15 ; forest, 19; illegal, 124, 125; of the Confederation, 210 ; of Northwest Territory, 229; Congress to establish inferior, 250 ; of the United States, 256; jurisdiction of, 256,263 ; procedure in, 257, 262.

Coxe, Tench, on the Constitution. 271.

Cravens, J. A., on the Emancipation Proclaination, 364 .
Creasy, E. S., cited, 74, 118, 441.

Criminal Cases. - See Jury.

Cromwell, Oliver, Lord Protector, 95 ; on Instrument of Government, 98.

Cromwell, Thomas, on Parliament, 3537.

Crown, election to, 2, 5, 6; interference in parliamentary elections, 36, 124; prerogative of, 72, 125, 144; conferred by Parliament, 126, 129; succession fixed, 127, 129, 130; king to commune with Churcl of England, 138; restrictions on king's movements, 139 ; defence of foreign dominions of, 139; and colonies, 145, 149, 156-157, 184186.

Cuba, condition of, 389; independence recognized, 390; United States and, 390-394.

Curtis, Benjamin R., dissent from Dred Scott decision, 346,441 .

Curtis, G. T., cited, 174, 441 .

Custom duties, control of, 44, 249, 251, 252.

Cutler, W. P. and J. P., Life of Rev. Manasseh Cutler, 238, 442 ; cited, 242.

DANA, R. H., cited, 329, 442.

Dane, Nathan, on Northwest Ordinance, 237.

Darrein presentment, trial upon writ of, 14.

Declaration of Independence, text, 183-188; conteniporary exposition, 188-192; critical comment, 192-203.

Declaration of Rights, text, 166169 ; contemporary exposition, 169173; critical comments, 173-181.

Declakation of Rights and GRIEvances of the Colonists in AmerICA, text, 155-157; contemporary exposition, 158-164; critical comment, 164-166.

Defence of the New-England Charters, text, 142-144; contemporary exposition, 144-150; critical comment, 150-154.

Delegated powers, 205, 263.

Delegates, to Congress of Confederation, 206 ; territorial, 233.

Despotism, from political partisanship, 296.

Dicey, A. V., cited, 120, 141, 442.

Dickinson, Joln, on the Constitution, 271.

Direct taxes, to be apportioned, 245 , 251.

Dispensation of laws, 125, 168; forbidlen, 131 ; exceptions, 131.

District of Columbia, control of, 251. 
Dower, 3,12 ; preference to widow's right of, 13 .

DRED ScotT Decision, text, 340-349; contemporary exposition, 349-353; critical comment, $351-357$; statemeut of the case, 341 ; dissent, 346 .

Dummer, Jeremiah, Defence of the New-England Charters, 142144,442 .

Dunning, W. A., cited, 369, 382, 442.

\section{CDINBURGH REVIEW, 73, 164,} 442.

Education, fostered, 234; and government, 299; in colonies, 397.

Edward the Confessor, his laws restored, $4,6,25$.

Edward I., Summons to ParliaMent, 34-35; Confirmatio CharTANUM, 43-45.

Elections, for parliament, 36, 80, 87-90 ; freedom of, $84,124,125,167$; judge of legislative, 91, 247; congressional, 206, 245-247; presidential, 253-254, 263-264. - See also Suffrage.

Electors of president, 253, 374; legislators and officials not to be, 253 .

Ellis, G. E., cited, 200.

Emancipation, compensated, recommended, 359, 361. - See also Proclamation.

Eminent domain, exercise of right of, $234,262$.

Equality, natural, 166, 183; Constitution based upon, 352 .

Escheat, service of an, 18.

Eulogies and Orations on Washington, $307,308,309$.

Excise, control of, 249 ; to be uniform, 249.

Executive power, in the Commonwealth, 81,85 ; in the United States, 253, duty of heads of departments, 255 . - See also Lord Protector, President.

Expenditures, regulation of, 93, 252.

Export duties, forbidden, 251, 252.

Ex post facto laws, forbidden, 251, 252.

GEDERALIST, 268.

Fee-farm, tenure, 17.

Feilden, H. St. C., cited, 47, 442.

Fifteentu Amendient, text, 375 ; contemporary exposition, 376-380; critical comment, $380-387$.

Fines, not to be arbitrary or excessive, $4,15,126,168,233,262 ;$ l how assessed 15; John to give up unjust, 21; illegal to grant future, 126.

Fisher, S. G., cited, 178, 226, 442.
Fiske, John, cited, 202, 225, 442.

Ford, H. J., cited, $225,442$.

Ford, P. L., Pamphlets on the Constitution, 267, 271, 272,442 .

Foreign relations, power over, 86, 207, $209,255,256$; alliances to be avoided, 301,303 ; policy of the United States, $300-305,322-326,401$.

Foreigners, removed, 19, 20; not eligible to office, 139.

Forest, king's, retained, 4 ; reduced, 19 ; court, attendance at, 19 ; abatement of evil customs, 19 ; charter confirmed, 43.

Forster, John, 442.

Forsyth, William, cited, 57, 442.

Fortescue, Sir John, on civil procedure, 51; De Laudibus Legum Anglia, 54, 442.

Fourteenth Amendment, text, 373375 ; contemporary exposition, 376380 ; critical comment, $380-387$.

Franklin, Benjamin, on Stamp Act, 158: Political, Miscellaneous, and Philusophical Pieces, 159; on the Constitution, 264.

Freedom, of the press, 168; of speech, $126,207,261$.

Freeman, Edward, cited, 39, 442.

Freeman's Jour'nal, on banks in 1819 , 317.

Free tenants, in chief, to be summoned to council, 13 ; aids from, 14 ; services of, 14 .

Fugitives, from justice, 206, 257; from labor, $258,360,361$. - See also Slavery.

GARDINER, S. R., cited, 8, 32, 40, $76,104,442$.

General Council, to impose aids, 13; how summoned, 13; organization, 13. - See also Parliament.

General warrants, 168, 188, 261.

General welfare, power to tax for, 249

George III., and colonies, 157, 184.

Giddings, F. H., cited, 421, 442.

Gilman, D. C., cited, 331, 442.

Gilpin, H. D., Madison Papers, 267.

Gladstone, W. E., cited, 275,442 .

Gneist, Rudolf von, cited, 32, 47, 76, 442.

Government, object of, 167, 183; best form, 167 ; right to change, 167,183 , 294; uniform, 169; preservation, 169, 290-304; obedience to, 294; necessity of an efficient, 294, 295; stability, 295 ; separation of powers, 297 ; religion, morality, and, 298; education and, 299. - See also Constitution, 
Republican government, United States.

Governor of territory, appointment, 229 ; qualifications, 229; duties, 230, 232 ; veto, 232.

Grant, U. S., on negro soldiers, 366 ; General O.der, 366, 442.

Grants, colonial, 159, 162.

Great Seal, power of, 51.

Greeley, Horace, on Dred Scott decision, $352 ;$ American Conflict, 353, 442.

Green, J. R., cited, 7, 22, 29, 59, 101, $104,134,197,443$.

Guaranty, of immunities of citizens, 257 ; of republican form of government, 258; of public debt, 214, 259, 375 ; of equal protection of the laws, 374.

Guizot, F. P. G., cited, 133, 443.

$\mathrm{H}^{\mathrm{A}}$ ABEAS CORPUS, forerunner of, 17; evaded, 69 ; act, $115-117,431$ 439 ; in territories, 233 ; suspension of, 251.

Habeas Colipus Act, text, 115-117, 431-439; contemporary exposition, 117 ; critical comment, 118-121.

Hallam, Henry, cited, $6,27,3 \overline{7}, 45,72$, $100,443$.

Hansard. - Sec Cobbett.

Hamilton, Alexander, on the Confederation, 219; Works, 219, 269, 443; on the Constitution, $267,268$.

Hare, J. I. C., cited, 319, 443.

Harper's Magazine, $339,414,443$.

Hart, A. B., cited, 224, 280, 338, 386, $412,443$.

Henry I., Coronation OATu and Charter, 1-5; William of Malmesbury on, 5 ; lager of Wendover on, 6 .

Irinsdale, 13. A., cited, 241, 443 .

Hitchcock, llenry, cited, 173, 443.

Hoar, G. F., cited, 240, 408, 443.

Holst, II. E. von, cited, 198, 223, 329, 354,443 .

Hosmer, J. K. cited, 38, 77, 109, 135, 443.

House of Representatives, apportionment, 245,374 ; election to, 245-247; qualifications, 245, 374; number in, 246 ; powers of, $246,247,248,253$, 264. - See also Congress.

Howard's Reports, 340.

Hurd, J. C., cited, 278, 443.

Hurd, L. C., cited, 118, 443 .

IMMUNITIES, of legislators, 69, 126, 207,248 ; of citizens guaranteed, $257,374$.
Impeachment, pardon not pleadable to, 140,255 ; in United States, 246, 247, $255,256$.

Implied powers, 251, 313.

Imposts, control of, 249,252 ; uniformity, 249.

Impressment, 186.

Inalienable rights, 148, 166, 183.

Independence. declared, 187; forced by the people, 191.

Indians, in Revolution, 186; trade, 211, 250 ; treatment of, 234 ; not taxed, 245.

Inquest. - See Jury.

Inquisition of life or limb, writ of, 17 . - See also Habeas Corpus.

INSTRUMENT OF Goveringent, text, 85-98; contemporary exposition, 9899 ; critical comment, 100-114.

Insurrections, suppression of, 258.

Invasion, protection against, 258.

TAMES II., arraigned, 123; abdicated, $124,129$.

Jameson, J. A., cited, 174, 221, 443.

Jameson, J. F., 280, 443.

Jefferson, Thomas, on Declaration of Independence, 192; Works, 192, 220, $273,326,443$; on the Confederation, 219 ; on the Constitution, 272 ; on the Monroe Doctrine, 325.

Jews, regulation of debts due, 12, 13.

John, Mlagxa Cinata, 9-25; promises restorations, 20,21 ; enforcement of Magna Charta on, 22.

Johnston, Alexander, cited, $367,443$.

Journal of First Congress, 155, 444; legislative, 214, 248; Journals of Congress, 164, 228, 444.

Judges, commission, 139, 256 ; salaries, 139,256 ; removal, 139 ; independence, $171,172,185$.

Judicial power of the United States, how rested, 256. - See also Courts.

Jurors, qualifications, 51-52, 126 ; penalty for false verdict, 53 ; treatment, 54 ; return, 126.

Jury, trial by, for embezzling a record, 51 ; in civil cases, $51,168,262$; advantages of, 53 ; abuse, 124 ; right of colonies to, 156, 185 ; in criminal cases, $168,262,597$; in territories, 233 ; in United States courts, 257, 262. - See also Jurors.

Justiciaries, 14.

Klith, Sus Whusam, on colonial I rights, 1600; Taxing the British Colonists, 161, 444. 
King. - See Crown.

King's Bench, illegal use, 124.

Knight's fee, regulated, 4,14 ; priority of, 17 .

TND, seizure for debt, 12; of felons, 16. - See also Property.

Laws, paramount, 18, 19, 68, 69, 71, 82 , 168, 234; faithful execution of, 256 ; Constitution the supreme, 259; due process, 262, 374; 110t violated by Missouri Compromise, 349 ; equal protection guaranteed, 374 .

Lay tenement, 15.

Lecky, W. E. H., cited, 199, 444.

Legislative power, how vested, in Commonwealth, 85, 94; in the United States, 245. - See also Congress, Northwest Territory, Parliament.

Legislative punishments, forbidden, 82, $251,252$.

Lincoln, Abraham, Proclamation of Emancipation, 358-364; Complete Works, 358, 362, 444; on Emancipation Proclamation, 366, 367.

Livermore, George, cited, 197, 444.

Loans, forced, forbidden, 67 ; exacted, 68.

Lodye, H. C., cited, 202, 416, 444.

London, aids, 13; ancient liberties, 13; gives up charter, $1+3$.

Long, J. D., on duty to dependencies, 399; Address before the Home Market Club $, 401,444$.

Lord Protector, chief magistrate, 85; assisted by council, 85; writs in his name, 85 ; powers, $86,92,94$; succession, 95; Oliver Cromwell first, 95 ; to take oath, 97.

Lowell, J. R., cited, 380, 444.

Luffman, J., cited, 132.

Macaulay, T. B., cited, 46, 74, $100,133,164,444$.

McCall, S. W., cited, 370, 444.

McCulloch $v$. The State of MaryLAND, text, 312-316; contemporary expusition, 316-318; critical comment, 318-320.

McKinley, William, Annual MesSAGES, 388-397 ; on war with Spain, 388-391, 398; on relation with Cuba, 390-394; on duty to dependencies, $391,394-399$; Speech at the Home Market Club, 399, 444.

Mackintosh, Sir James, cited, 28, 444.

McLaughlin, A. C., cited, 284, 38t, 444.

McIaster, J. B., cited, 337, 444.
Madison, James, on Monroe Doctrine, 326 ; Works, 327, 444.

Magna Charta, text, 9-25; contemporary exposition, 25-26; critical comment, 27-33; enforcement, 22; confirmed, 43 ; pleadable, 43; paramount law, 43; read in churches, 43; penalty for breaking, 43; in Petition of Right, 68,69 ; claimed by colonists, $144,147,159$.

Maletote of wools, released, 44 .

Malnesbury, William of, 5, 444.

Manors, in king's demesne, rent of, 15.

Marque and reprisal, control of letters, $207,209,213,250,252$.

Marriage, freedom, 2, 3.

Marshall, John, cited, 152, 444; delivers McCulloch vs. Maryland decision, 312.

Martial law, in time of peace, 69,70 ; revoked, 71; in United States, 262.

Mason, George, on the Constitution, 267.

Mason, J. MI., on Washington's Farewell Address, 308.

May, Sir T. E., cited, 120, 445.

Measures. - See Weights.

Medley, D. J., cited, 113, 445.

Merchants, security and freedom of transit, 18.

Merriman, R. B., Life of Thomas Cromwell, 36,445 .

Message, the president's, 255.

Military service, abroad, 45,81 ; impressment of colonists, 186 .

Militia, of Commonwealth, 82 ; a safeguard, 168, 208, 261; control of, 250 .

Minot, G. R., on Washington's Farewell Address, 308.

Missouri Conıpromise, unconstitutional, 345 ; and rights of property, 345,349 .

Money, regulation and coinage, 211, $213,250,252$; power to borrow, 212, 213, 250; counterfeiting, 250.

Monroe, James, Monroe Doctrine, 321-323.

Monrot Doctrine, text, 321-323; contemporary exposition, 323-328; critical comment, 329-339.

Morality and government, 298-299.

Morse, J. T., cited, 330, 370, 445.

Morte d'Ancestor, trial upon writ of, 14 .

Mulford, Elisha, cited, 221, 445 .

NATURALIZATION, obstruction of,

1 184; control of, 250 .

Nary, under the Commonwealth, 86, 93; control of, 207, 212, 250.

Negroes, citizenship, $342,347,373$; inferior race, 343 ; soldiers, 364,366 ; suffrage, 375,379 . 
Nicolay, J. G., and Hay, J., cited, 368 , 445.

Niles, Hezekiah, on McCulloch $\imath$ ss. Maryland, 316; Niles' Weekly Register, $317,318,445$.

Nobility, titles forbidden, 207, 252.

Nortingest Ordinasce, text, 228236 ; contemporary exposition 237238; critical comment, 238-243.

Northwest Territory, property in, 228; government, 229-233; future statehood, 233, 235, 236; compact with, 233 ; bill of rights, 233 ; part of the Confederation, 234 ; control of public domain, 235; free waterways, 235; slavery, 236.

Novel disseisin, trial upon writ of, 14.

Nugent, Lord, cited, 72.

ATH, of Lord Protector, 97; prescribed by Parliantent, 127 ; coronation, 1, 130; of territorial officers, 232 ; of president, 254 ; to support the Constitution, 259.

Officers, obedience to the laws, 19, 71; responsible to the people, 167 ; positions not hereditary, 167 ; rotation, 167 ; legislators not eligible, 248, 253; foreign favors, 252 ; appointinent, 255 ; comnission, 256 ; impeachable, 256; oath, 259 ; religious test, 259; disabilities from Civil War, 374 .

Olney, Richard, cited, 310,334 ; on the Philippines, 401; Growth of our Foreign Policy, 402.

Otis, James, on colonial rights, 159 ; Rights of the British Colonies, 160, 445 .

Outlook, 416, 445 .

Oyer and terminer, sessions of, 116.

DaINe, Thomas, on Washington's Farewell Addres3, 307.

['algrave, Sil James, cited, 27, 445.

l'ardon, to murderers, 4; power of Lord Protector, 86, 93; not pleadable to impeachment, 140,255 ; presidential power, 255.

Parliament of England, germ of, 13; summons to, $34,87-92$; qualification of members, $35,90,91,139$; powers of, $35,36,81-84,86,92,94-96,125-$ 126; limitations, $81-84,92$; elections to, $36,80,84,87-92,124-125$; StatUTE, 8 II F. VI. CA1. 12, 49-51; Petituon of Right, 67-71; Rump, to dissolve, 79.84; number of members of, 80,87 ; apportionment, 80,87 ; quoruin, 80,91 ; term, $81,84,86$; ex- tra, 81, 91-92; sessions, 79, 81, 86, 92, 126 ; adjournment, 86,92 ; resistance in arms to, 84; H A UEAs Corinus ACT, 115-117, 431-439; BrLI, of Rrgirts, 122-132; arraigns James II, 123-124; the Convention, 124; freedom of speech in, 126 ; claims certain rights, 126; confers the crown, 126, 129; fixes the succession, 127, 129-130; prescribes oath of allegiance and supremacy, 127 ; anti-l'apist accession oath, 131; Act of Setrlemkxt, 138-140; foreigners excluded from, 139 ; and colonies, 144-146, 158-163, 185 ; colonial representation in, 156 , $160-161$; colonial opinion of, 158 ; colonjes petition, 164; arraigned, 185 . - See also General Council.

Patents, laws for, 2000.

Patersoll, James, cited, 119, 445.

Peace and war, power, 86, 92, 208, 209 , 213, 250, 252 .

People, rights of, 4, 128; source of power, 167, 183; responsjbility to, 167 ; force independence, 191 ; reserved power, $263,294$.

Personal liberty, security of, 17, 18, 70, $125,168,261-262,374,397$; violated, 68-69, 123, 185. - See also Bail, Civil Rights, Fines, Habeas Corpus, Jury, Punjsliments, Petition.

Petition, right of, 125, 261; colonists claim, 157.

Petition of Right, text, 67-71; contemporary exposition, 72; critical comment, 72-77.

Petty serjeanty, tenure, 17.

Philippines, ceded, 392; Congress responsible for goverument, 394, 395; duty of United States, 394, 398-401; future development, 395 ; education, 397 ; civil rights, 397 ; effect on foreign policy of United States, 401 .

Pierce, F. L., cited, 369, 445.

Piracy, laws against, 209, 250.

Pitt, William, on reconciling the colonjes, 163; Speech in the House of Lords, 163.

Pleas of the crown, minor officials not to liold, 15.

Political partisanship, dangers, 296.

Political Science Quarterly, 411, 445.

Pollock and Maitland, cited, 7, 32, 445.

I'orto Rico, military government, 392 ; civil government, 396 ; local self-government, 396; education, 397; civil rights, 397 .

Post-office, control, 212, 250.

Pownall, Thomas, on colonial rights, 147; Administration of the Colonies, 148,445 . 
Pracipe, writ, forbidden, 17.

Premuire, penalty incurred, 117.

Precedent, fear of illegal, 71, 126.

Prerogative, royal, 72, 125, 144.

President, veto, 249; term, 253; election; 253,263 ; qualifications, 254 ; remuneration, 254 ; succession, 254 ; oatll, 254 ; dnties and powers, 255-256 ; inpeachment, 247,256 ; war powers, 363.

Preston, H. W., Documents, 166.

Privy Council, illegal use, 68; duties, 139 ; restriction on membership, 139 .

Prize courts, control of, 209, 250.

Proclamation of Emaxcipation, text, 358-364; contemporary exposition, 36t-36t; critical comment, 367372 ; constitutional basis, 363,364 ; results, 364; call for, 365; Lincoln on, $366,367$.

Property, disposition of personal, 4, 16 ; seizure for debt, 12; protection of, 16, $83,166,234,261-262,374$; in Northwest territory, 228; in slaves, 345; rights and Missouri Compromise, 345, 349.

Public debt, assumed and faith pledged, 214, 259; unquestioned, 374; Southern, repudiated, 375 . - See also Public faith.

Public domain, in Nortlıwest Territory, 235 ; control of, 251, 258.

Public faith and credit, to be kept, 82, $97,214,259,299$.

Pulpit and Rostrum, 352, 445.

Punishments, not to be cruel or unusual, 126, 168, 233, 262.

UARTERING troops, 69-70, 185, 261.

Quorum, of Parliament, 80, 91; of Congress, 247.

Quo warranto, writ, against Massachusetts' charter, 143.

DAMISAY, DAviD, on Declaration 10 of Independence, 191 ; American Revolution, 191, 445 .

Randolph, C. F., cited, 403, 445 .

Ransome, Cyril, cited, 8, 32, 39, 112, $136,141,445$.

Reconstruction amendments, 373-375; contemporary exposition, 375-380; critical comment, $380-387$.

Records, legal, amendment, 49-50 ; felony to enbezzle, 51; power of Great Seal, 51; of states, faith and credit to, 206, 257 .

Reddaway, W. F., cited, 337,445 .
Reliefs, to be just, 2, 3; ancient, restored and specified, 11; of an escheat, 18.

Religion, state, 83.96 ; freedom, 83,96 , $169,233,259,261$; restrictions, 83,84 , 86 ; morality, government, and, 298 .

Report on the Digniry of a Peer, 34.

liepresentation, right of, $79,168,184$, 185, 233. - See also Taxation.

Representative. Parliament, 80.

Republican govermment, guaranteed, 236,258 ; military establishments hostile to, 292; separation of powers, 297 ; foreign influence on, 302 . - See also Government, United States.

Requisition, of criminals, 206, 257; on states, 209, 212.

Revenue, control of, under Commonwealth, 93, 94; rajsed by prerogative, 125 ; control of bills in Congress, 248. - See also Benevolences, Taxation.

Rhodes, J. F., cited, 356, 446.

Richardson, J. D., Compilation of Messages, 321, 388, 446.

Roger of Wendover, on Henry I., 6 ; Flowers of History, 6, 26, 447; on Magna Charta, 25.

Roman Catholies, not to bear arms, 125; excluded from the crown, 130. - See also Churcli, Religion.

Ropes, J. C., 446.

AANT-GERMIAN, Christopinkr, on treatment of jurors, 54 ; Doctor and Student, 54, 446 .

Sanborn, J. T. A., 446.

Schouler, James, cited, 178, 332, 354, 446.

Schurz, Carl, cited, 406, 446 .

Scots, king of, an English vassal, 22.

Scutages, to be laid by General Council, 13.

Sectionalism, dangers to the Union, 293.

Senate, elections, 246, 247 ; equal state representation, 246 ; term, 246 ; organization, 246, 247; qualifications, 246, 374 ; presiding officer, 247 ; powers, $247,248,254,255,264$. - See also Congress.

Separation of powers, $81,167,171,172$, $207,248,297$.

Services, lawful, 11 ; military, abroad, 45: public, regulation, 167 .

Sewall, J. M., on Washingtou's Farewell Address, 306.

Slavery, reference struck from Declaration of Independence, 192; in territories, 236,345 ; representation, 245 ; fugitive slaves, 258, 360-361; under the Constitution, 350 ; compensated 
emancipation, 359,361 ; slaves in rebel states emancipated, 359-364; aholished, 373. - See also Negroes, Slave trade.

Slave trade, regulation, 251.

Smith, E. P., cited, 279.

Socage, tenure, 17.

Sovereignty, state and national, 205, $215,259,315,317$.

Spain, war with United States, 388391 ; peace, 392 , 3198 .

Sparks, Jared, cited, 309.

Speaker, House to choose, 246.

Spence, George, cited, 56, 446.

Stamp Act, subverts rights of colonies, 156; burdensome, 157; Franklin on, 158. - See also Colonies.

Stamp-Act Congress, Declaration of Rights and Gruevances of TIIE Colosists is AMERICA, 155$15 \pi$.

Stauding army, of Commonwealth, 9:3 ; illegal, 125; dangers, 169, 292 ; and civil power, $84,169,185$; kept in colonies, 185; forbidden, 208, 252.

States, advised to form governments, 171-173; residual powers in, 205, 263; equal vote in Confederation, 207 ; in Senate, 246,259 ; limitation of powers, 207-208,252, 314-315,374-375; inilitia 208,250 ; requisitions on, 209,212 ; disputes between, settlement under Confederation, 210; new, 235-236, 258; national protection of, 258; suits against, 263 ; no control over federal powers, 315; sovereignty, 205, 259, 315,317 ; citizenship, 343, 373.

StatuTk, 8 HeNis VI., Car. 12 , text, 49-51 ; contemporary exposition, 51-54; critical comment, 54-65.

Statutes at Large, 49, 446.

Slatutes of the Realm, 2, 9, 43, 67, 115, $122,138,446$.

Statutum de Tallagio non concedendo, claimed, 67 .

Stevens, C. E., cited, 65, 136, 225, 281, 446.

Story, Joseph, cited, 197, 220, 274, 318, 446 .

Stubbs, William, Stect Charters, 1, 67 ; cited, 7, 29, 38, 46, 446.

Suffrage, qualitications, 89-90, 167; in the United States, 375. - See also Elections.

Sumuons ro Parruasent, text, 34-3.5; contemporary exposition, $35-3 \overline{7}$; critical comment, $37-41$.

Sunwer, W. G., cited, 319, 404, 44\%.

Supreme Court, jurisdiction, 256 ; McCurlocil vs. MARYLANI, 312-316; to interpret Constitution, $313-316$,
343-344; Dred Scott Decision, $340-349$.

Sureties, when liable, 12.

I TLLAGE, and representation, 67.

Taney, R. B., delivers Dred Scott decision, 340 ; criticised, 350-352.

l'arbell, Ida M., eited, 371, 446.

Taswell-Langmead, J. P., cited, 31, 38, $46,60,103,119,134,446$.

'laxatioll, and representation, 44, 67, 86, $156,159,160,162,168,185,245$; direct, apportioned, 245,251 ; control of, 249; necessary, 299. - See also Aids.

'Taylor, Hanuis, cited, 47, 63, 75, 103, $121,135,446$.

'l'erritory, control of, 258 ; slavery in, 345,349 ; wly acquired, 348 ; as property, 349. - See also Northwest Territory.

'luirteenth Amenduest, text, 373; contemporary exposition, 375-380; critical comment, $380-387$.

Thomas, B. F., call for emancipation, 365.

Thorpe, F. N., cited, 179, 283, 446.

'l'bwaites, R. G., cited, I53, 446.

Tomnage duties, control, 252.

Trausportation of prisoners, forbidden, 117 ; a grievance of colonies, 185 .

Treason, no pardon for, 86 ; high, to fail to summon Parliament, 90 ; rights of those accused of felony or, 116; against the United States, 257.

Treaties, control, $207,209,252,255$; supreme law, 259. - See also Foreign relations.

Trial, by peers, $15,18,68,168,234$; rights of accused, 262 . - See also Jury.

Tucker, G. F., cited, 333, 447.

Tucker, Dr. Josiah, on taxing colonies, 161 ; Letter from a Merchant, 161, 447.

TTITED STATES, style, 183, 186, 205, 245; declared independent, 186-187; government by delegated powers, 205, 263, 313; sovereignty, $215,259,315,317$; admission of new states, 258; guaranty to states, 258; value of the Union, 290-292; preservation, 293-304; foreign policy, 300$305,322-328,401$; preservation of, object of Civil War, 358; citizenship, 373; disqualification for office, 374 ; suffrage, 375 ; war with Spain, $388-391,392$, 398; attitude and duty to Cuba, 389-394; and the colonies, 394-401; problems, 399. - See also Confederation, Congress, Constitution. 
VETO, power of, 92, 232, 249; of colonial laws, 184.

Vice-President, president of Senate, 247 ; term, 253; election, 253, 263; qualifications, 264; succession to presidency, 254; impeachable, 256.

Villein, fiues of, 15.

Virginia Convention, Declaration of Rights, 166-169.

W AINAGE, of villeins, 5.

Walsh, Robert, cited, 150,447 .

War, control of, 86, 92, 208, 209, 213, 250,252 ; powers in Enlancipation Proclamation, 363.

Wardship, regulated, 2, 3, 11, 17.

Warrens. - See Forest.

Washington, George, on Virginia Biil of Rights, 169; Works, 169, 219, $270,271,286,447$; on the Confederation, 218; on the Constitution, 269271, 294; Farewell AdDress to THE l'EOPLE OF THE UNITHD STATES, 286-306; declines a third term, 287; on his own administration, 288, 304306 ; on value of the Union, 290 ; on its preservation, 291-305; on its foreign policy, 300-304.

Washington's Farewell Andress TO THE PEOPLE OF THE UNiTED STATEs, text, 286-306; contemporary exposition, 306-309; critical comment, 309-311.
Wears, regulated, 17.

Webster, Daniel, cited, 192, 238, 273; on the Monroe Doctrine, 327; Works, $328,447$.

Webster, Pelatiah, on the Confederation, 216; Remarks on a Pamphlet, $217,447$.

Weights and measures, uniform, 17; control, 211, 250.

Welsh, restorations to the, 21 .

Wendover. - See Roger.

Wheaton's Reports, 312.

Widow, rights of, 3, 12, 13, 228.

William of Malmesbury, extols Henry I. 5; Chronicles of the Kings of England, 5, 444.

William and Mary, declared king and queen, 126; accept, 127.

Willoughby, W. W., cited, 319,447 .

Wilson, Henry, on Dred Scott decision, 353; Rise and Fall of the Slave Power, $353,447$.

Winsor, Justin, 165, 202, 447.

Witnesses, necessary, 18, 168, 257, 262. - See also Jury.

Woman, limited right of accusation, 21.

Woolsey, T. S., cited, 336, 447.

VEAS AND NAYS, under the Conmonwealth, 83; in Congress, 248. 





$$
{ }_{14}{ }_{4}
$$



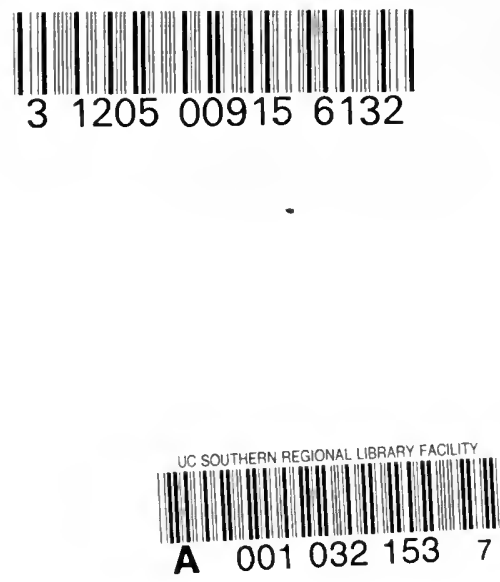


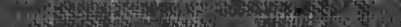
Hof

the

Why (5) W. (4) Hith

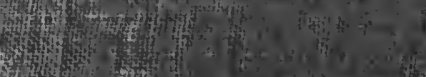

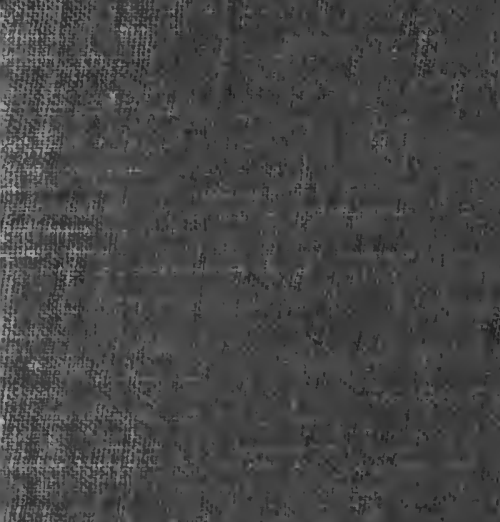

(t)

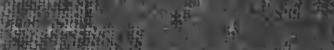

Hith

(1)

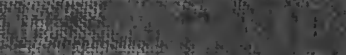

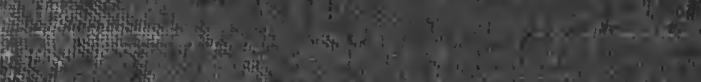
the

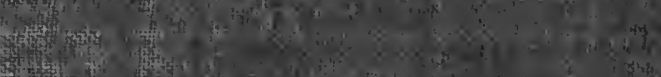

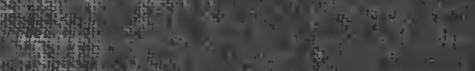

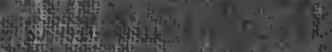

(5)

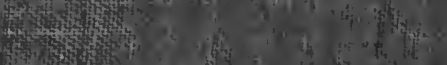

(5)

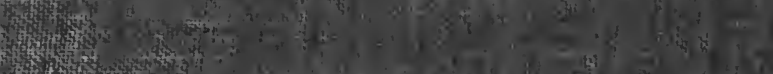

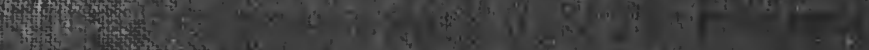

(5)

the

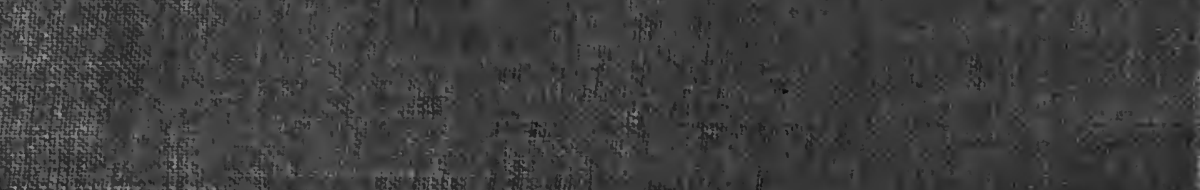

(5)

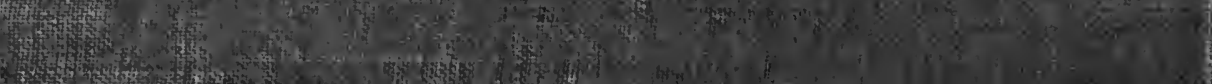

